\title{
COLONIAL CORALS FROM THE EARLY APTIAN SILICICLASTIC Montlivaltia MARLS OF JUMILLA (MURCIA, SPAIN)
}

\author{
Hannes LÖSER ${ }^{1}$ and José Carlos SALDAÑA \\ VILLODRE ${ }^{2}$
}

${ }^{1}$ Estación Regional del Noroeste, Instituto de Geología, Universidad Nacional
Autónoma de México, Blvd. Luis Donaldo Colosio S/N y Madrid, Campus
UNISON, 83000 Hermosillo, Sonora, México; loeser@paleotax.de
${ }^{2}$ C / Dr. Fleming $462^{\circ}$ B, 03690 San Vicente del Raspeig, España;
josecsv@ yahoo.es

Löser, H. \& Saldaña Villodre, J. C. 2008. Colonial corals from the Early Aptian siliciclastic Montlivaltia Marls of Jumilla (Murcia, Spain). [Corales coloniales del Aptiense Temprano de las margas siliciclásticas de Montlivaltia de Jumilla (Murcia, España).] Revista Española de Paleontología, 23 (1), 1-6. ISSN 0213-6937.

\begin{abstract}
Three species of colonial scleractinian corals are reported from Early Aptian sandy marls of the so-called Montlivaltia marls from a section exposed on the SE flank of the Sierra de Sopalmo, south of Jumilla in Murcia, Spain. While solitary corals of the genus Montlivaltia are extremely common in the marls, colonial corals are rare. The three colonial coral species presented here (Cryptocoenia sp. n. aff. C. pygmaea, Holocystis elegans, and Columnocoenia aragonensis) are all common Early Cretaceous species. They range in age from the late Barremian to early Albian with the exception of Columnocoenia aragonensis, which ranges from the Valanginian to Cenomanian. Their geographical distribution is large and all species were found in the central Tethys as well as in the Caribbean province. All species were previously found in siliciclastic environments and while Holocystis elegans occurs primarily in such facies, the other two species occur in pure carbonates as well.
\end{abstract}

Key words: Corals, Scleractinia, Cretaceous, Aptian, Jumilla, Murcia, Spain.

\section{RESUMEN}

Se reporta la presencia de tres especies de corales coloniales en las margas arenosas denominada margas de Montlivaltia del Aptiense inferior de una sección expuesta en la vertiente suroeste de la sierra de Sopalmo en el sur de Jumilla (Murcia, España). Los corales solitarios del género Montlivaltia son extremadamente abundantes en las margas, mientras que los corales coloniales son escasos. Las tres especies de corales coloniales (Cryptocoenia sp. n. aff. C. pygmaea, Holocystis elegans, y Columnocoenia aragonensis) son especies comunes del Cretácico Inferior. Sus rangos son del Barremiense superior hasta el Albiense inferior, a excepción de Columnocoenia aragonensis que existió desde el Valaginiense hasta el Cenomaniense. La distribución paleogeográfica de las tres especies es grande; vivieron en el Tethys central y en la provincia del Caribe. Las tres especies fueron anteriormente encontradas en ambientes siliciclásticos. Holocystis elegans es una especie que se registra predominantemente en ambientes siliciclásticos, mientras que las otras dos especies también son comunes en niveles carbonatos puros.

Palabras clave: Corales, Scleractinia, Cretácico, Aptiense, Jumilla, Murcia, España.

\section{INTRODUCTION}

Environments with fine to medium coarse siliciclastic sediments imply a high rate of turbidity and soft bottoms. They are not normally colonised by zooxanthellate shal- low marine colonial corals because the high turbidity reduces the light reaching the sea floor and sediment may cover or even bury the corals. Solitary corals, with their comparably larger soft bodies, are generally better adapted to such facies as they are better prepared to remove sedi- 
ments from their body (for details and examples see Stafford-Smith \& Ormond, 1992; for considerations in the fossil record Sanders \& Baron-Szabo, 2005). The small fauna presented here shows, however, that colonial corals at least tried to invade such unfavourable environments. The three colonial corals in this study were found among hundreds of solitary corals, and were apparently unaffected by the high sedimentation rate.

\section{STUDY AREA AND MATERIAL}

The study material comes exclusively from the Sierra de Sopalmo area near Jumilla (Murcia, Spain; Fig. 1). This small mountain range forms part of the larger Betic Range (Arias et al., 1993) and is tectonically influenced by the Prebetic Domain. The section exposed at the SE flank of the Sopalmo anticline ranges in age from the Aptian to the Campanian with a hiatus from the Turonian to Santonian (Arias et al., 1993; Vilas et al., 1998). It is composed primarily of marine clastic and carbon- ate sediments. Its second unit consists of a partly sandy marl intercalated with some banks of calcarenites, which corresponds to an outer shelf position in relatively deep water. Informally, these marls are called Margas con Montlivaltiidae (Montlivaltiidae marls) or Montlivaltia beds because of the high number of solitary corals of the genus Montlivaltia Lamouroux, 1821 weathering out from the marls. Due to the presence of the orbitolinid foraminifer Palorbitolina lenticularis (Blumenbach, 1805) it is assigned to the Early Aptian.

The marls contain a full marine fauna composed of three species of Montlivaltia (M. multiformis Toula, 1889, M. sp. 1, M. sp. 2; Morycowa et al., 2001), some gastropods, bivalves (among others Trigonia sp., Plicatula sp., oysters, rudists), cephalopods, brachiopods (terebratulids and rhynchonellids), echinoids (Discoides sp. and Saleniidae), isolated asteroid plates, crinoids (Decameros sp.) and a fauna of benthic and planktonic foraminifers. Whereas the solitary corals of the genus Montlivaltia are very common, all other elements of the macro fauna are rare, except for the brachiopods.

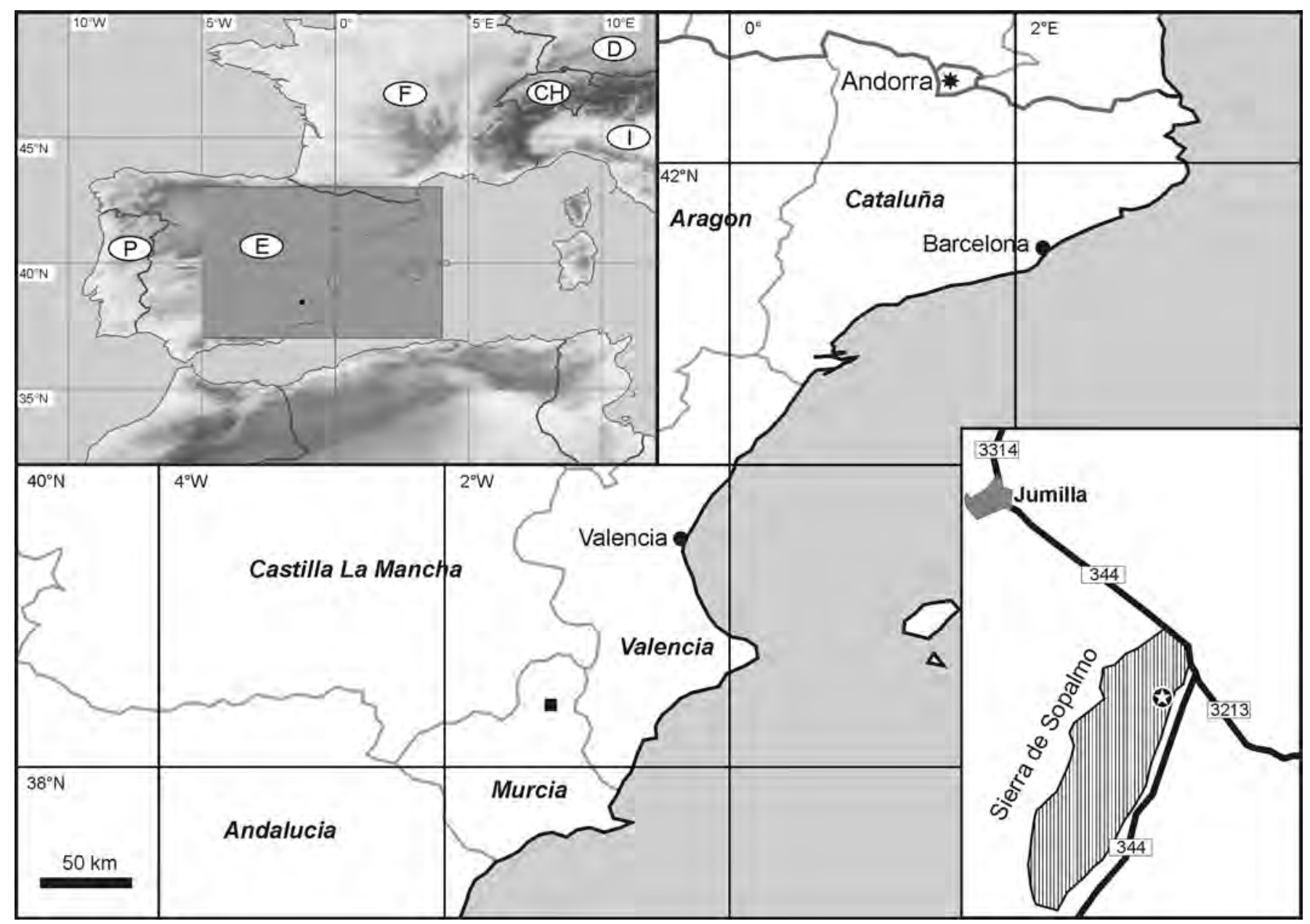

Figure 1. Study area. Sample location marked with 
The colonial corals presented here are all isolated finds. Due to the inclined outcrop area and the high rate of erosion, horizontal sampling of macrofossils is almost impossible. Attached sediment identifies the samples clearly as being derived from the Montlivaltia beds; one colonial coral is even attached to a Montlivaltia coral. Colonial corals are extremely rare in this area and the samples presented here were found during three years of continuous search in the outcrop area by the second author.

The three coral samples were collected by the second author and were transferred to the collection of the Museo Geológico del Seminario de Barcelona, Spain (MGSB). Thin sections were obtained from two specimens. One specimen was too small for this type of study.

\section{DESCRIPTION OF MATERIAL}

The following institutional abbreviations are used:

ERNO, Universidad Nacional Autónoma de México, Instituto de Geología, Estación Regional del Noroeste, Hermosillo, Mexico;

GPIB, Geologisch-Paläontologisches Institut Bremen, Germany;

IRScNB, Institut Royal des Sciences Naturelles de Belgique, Brussels, Belgium;

MB, Museum für Naturkunde der Humboldt-Universität, Berlin, Germany

MHNG, Muséum d'histoire naturelle de la Ville de Genève, Switzerland;

PU, Museo di Geologia e Paleontologia dell' Università di Torino, Italy;

SLD, H. Löser Collection, Dresden, Germany (being transferred to the Bayerische Staatssammlungen München, Germany)

ZSH, Zumsteinhaus (H. Scholz Collection), Kempten, Germany

The following abbreviations are used to describe the dimensions of the corals: c, calicular diameter; ccd, distance of calicular centres; s, number of septa; sc, number of costae

The following abbreviations are used in the synonymy lists: $\mathrm{v}=$ the author has seen the material belonging to this citation;

$*$ = first publication. A year in italic typesetting indicates that the citation was provided without description and illustration.

Order SCLERACTINIA Bourne, 1900

Suborder STYLININA Alloiteau, 1952

Family Cyathophoridae Vaughan \& Wells, 1943

Genus Cryptocoenia d'Orbigny, 1850

\section{Cryptocoenia sp. n. aff. C. pygmaea \\ (Volz, 1903)}

Fig. $2 \mathrm{a}, 2 \mathrm{~b}$

v 1976 Cyathophora miyakoensis (Eguchi 1936); Turnšek and Buser, p. 11, 38, pl. 1: 3-5.
1981 Cyathophora pygmaea Volz 1903; Turnšek and Mihajlović, p. 18, pl. 13: 1, 2.

v 1998 Adelocoenia fontserei (Bataller 1947); Schöllhorn, p. 74, pl. 18: 7, pl. 27: 2-4.

? 2001 Pseudocoenia sp.; Morycowa et al., fig. 4h.

v 2003 Confusaforma weyeri Löser, 1987; Baron-Szabo and González León, p. 207, fig. 7B.

v 2008 Cryptocoenia aff. pygmaea (Volz, 1903); Tomás et al., fig. 14A.

Dimensions: c 0.9 - $1 \mathrm{~mm}$, ccd 1.4 - 1.5 mm, s 6-9, sc 12 .

Description: A small but very well preserved specimen that shows no trace of sediment. The attachment area is small. The coral was probably attached to a shell or other small solid object that is no longer preserved. Calices small, round, with a clear coenosteum that is filled with the non-confluent to sub-confluent costae and thin dissepiments. Margins of the calices slightly elevated above the colony surface. Only the first cycle of very short septa is complete. The septa reach between 10 and 20 percent of the calicular diameter. The beginning of a second septal cycle can be traced. The septa are very short and only form ridges. Up to 12 costae were counted. Endotheca is well developed and shows tabulae. Budding extracalicular.

Remarks: The type material of Cyathophora pygmaea Volz, 1903 got lost during the Second World War. A study on the coral fauna of the type area (Morycowa, 1971) did not yield material comparable to the description given by Volz (1903). The characteristics of Cyathophora pygmaea are only known from the literature. Volz gives a good description: calicular diameter between 0.5 and $0.75 \mathrm{~mm}$, one to two septal cycles. The present material (and the material given in the synonymy list and under occurrences) has slightly larger calicular dimensions and does not fit the dimensions of $C$. pygmaea. Besides the lost type material of $C$. pygmaea, samples of comparable dimensions are also known (syntype PU 18113 of Polytremacis kiliani Prever, 1909; material collected by the first author from the Early Albian of Mexico). It is therefore assumed that two species exist, with the present material belonging to a previously undescribed species.

Material: MGSB 73673.

Occurrence: Early Cretaceous of Slovenia (Levpa, Banjska planota). Early Aptian of Serbia (Sopot) and Spain (Valencia, Castellón, Benicasin, La Venta). Early Late Aptian of Spain (Cataluña, Montsec de Rubies, La Cabrua, SLD 6312; Cataluña, Alt Urgell, Senyús). Late Aptian of Spain (Cataluña, Alt Penedès, Can Pascual, SLD 6295). Early Albian of Mexico (Sonora, Arizpe/Cucurpe/Sierra San Jose/ Tuape, ERNO L-4488, L-4278, L-4411, L-4428).

Range: Aptian to Early Albian.

Genus Holocystis Lonsdale, 1849 
Holocystis elegans (Lonsdale, 1849)

Fig. 2c

1847 Astrea ? elegans Fitton, p. 296 [nomen nudum, non Astrea elegans Goldfuss, 1826].

* v 1849 Cyathophora ? elegans Lonsdale, p. 83, pl. 4, figs 12-15.

non 1883 Tetracoeniaelegans; deFromentel,p.520,pl.139,fig. 1.

1927 Holocystis elegans (Fitton); Ryder, p. 120, figs 19.
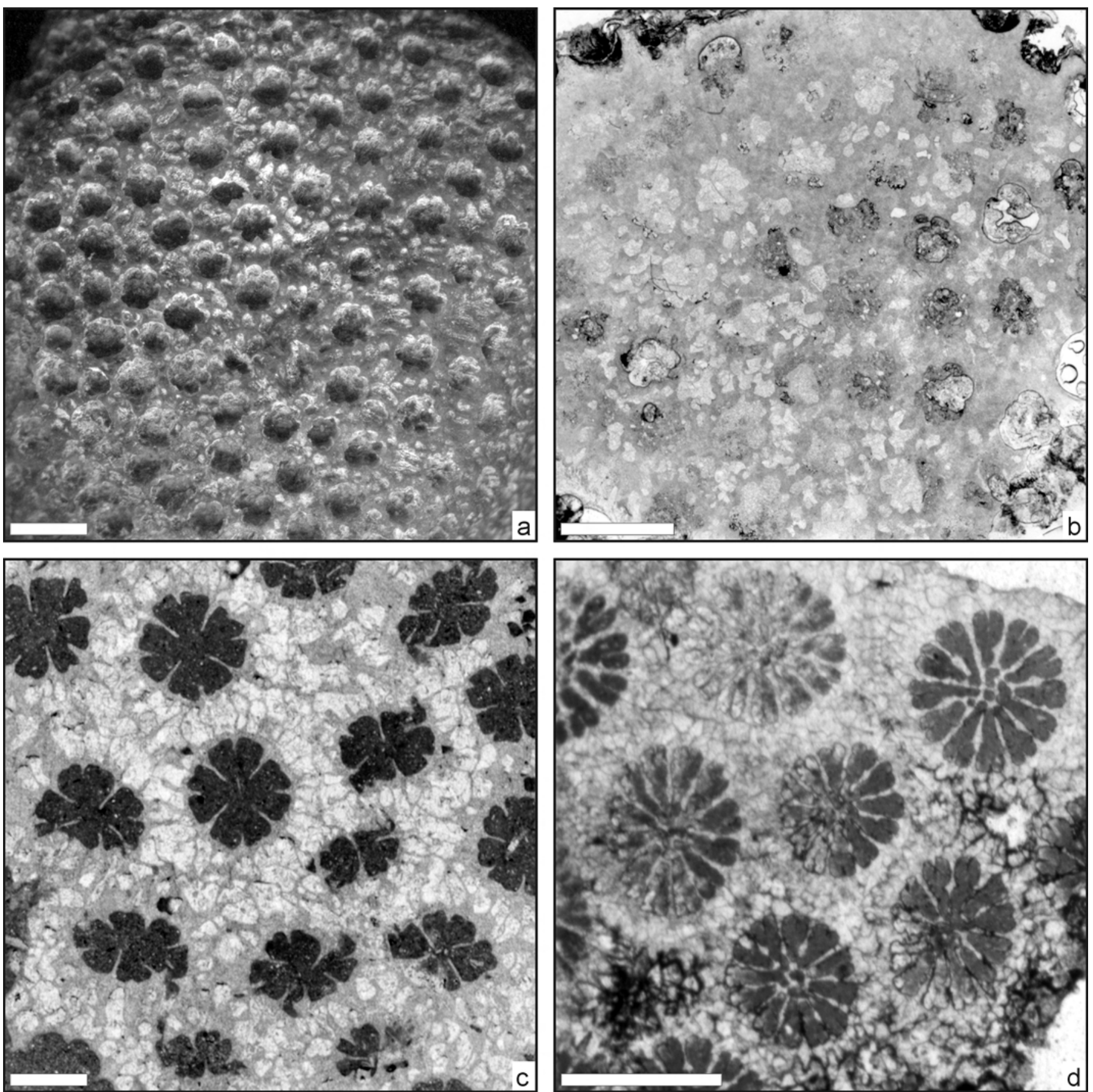

Figure 2. a-b, Cryptocoenia sp. n. aff. C. pygmaea (Volz, 1903); a, surface; b, acetate peel. c, Holocystis elegans (Lonsdale, 1849); thin section. d, Columnocoenia aragonensis (Alloiteau, 1946/47); thin section. All scales $2 \mathrm{~mm}$. 
Dimensions: c $2.5-2.7 \mathrm{~mm}$, ccd 4 mm, s 8-12, sc 16-20.

Description: The pillar-like colony is attached to a Montlivaltia and partly overgrew this solitary coral. Calices in plocoid arrangement, with a wide coenosteum, made of the non-confluent or sub-confluent costae. Calices round or rectangular, very regular in form and size. Septa in four systems. Those of the first cycle are long, almost reaching the centre of the calice. Those of the second cycle are much shorter, reaching only $10 \%$ of the calicular diameter. Septal faces smooth. Septa of both cycles always straight and free. The third cycle of up to four septa can be traced as small ridges. There may be more costae than septa, they can be long and interconnected with costae of other calices. Wall septo-parathecal. Endotheca well developed and made up by tabulae. Budding extracalicinal.

Remarks: In other locations the species has been found in facies with an input of siliciclastica. Based on its dimensions, the specimen fits completely in the range of H. elegans. This is the first indication of this species in Spain.

Material: MGSB 73675 with one thin section.

Occurrence: Early Aptian of the United Kingdom (Isle of Wight, Atherfield/Atherfield point). Late Barremian-Early Aptian of Mexico (Sonora, Municipio Ures, Cerro de Oro). Early Albian of Mexico (Sonora, Municipio Ures, Cerro de Oro).

Range: Late Barremian to Early Albian.

Suborder FAVIINA Vaughan \& Wells, 1943

Family Placocoeniidae Alloiteau, 1952

Genus Columnocoenia Alloiteau, 1952

Columnocoenia aragonensis

(Alloiteau, 1946/47)

Fig. $2 d$

1926 Astrocoenia asteriscus Weissermel; Dietrich, p. 96.

* v 1946-47 Stephanocaenia aragonensis Alloiteau, p. 208, pl. 3: 10.

1959 Stephanocaenia aragonensis Alloiteau 1947; Bataller, p. 28, text-fig. 790.

v 1989 Columastrea striata (Goldfuss 1829); Löser, p. 116, text-fig. 22, pl. 25: 1.

v 1994 Columnocoenia ksiazkiewiczi Morycowa 1964; Löser, p. 19, text-fig. 10.

v 2008 Columnocoenia aragonensis Alloiteau, 1946-47; Tomás et al., fig. 14E.

Dimensions: c $2 \mathrm{~mm}$, ccd 2 - $2.5 \mathrm{~mm}, \mathrm{~s} 24$.

Description: Fragment of a large poorly preserved colony. Attachment area not preserved. Colony plocoid. Calices round. Coenosteum narrow. Septa compact, thin, in six systems. Those of the first cycle reach to the centre of the calice and bear pali- forme lobes that may unite in the centre of the calice hide a small circular columella. The septa of the second cycle are slightly shorter and slightly thickened in the middle. The septa of the third cycle are short, reaching only half the length of those of the second cycle. Often they are connected to those of the second cycle (which clearly causes the swellings). The septal faces bear rare thorns. Septal upper border unknown. The costae are non-confluent. Endotheca made of dissepiments. Budding extracalicinal.

Occurrence: Late Barremian to Early Aptian of Mexico (Sonora, Municipio Ures, Cerro de Oro, ERNO L-4321). Early Aptian of Egypt (Shebh Gezirat Sena, Maghara Mt, GPIB SM01), Germany (Bayern, Allgäuer Helvetikum, ZSH H-KU 793) and Spain (Valencia, Castellón, Benicasin, La Venta). Early Late Aptian of Spain (Aragón, Las Aras). Late Aptian of Mexico (Sonora, Municipio Ures, Cerro de Oro, ERNO L-4362) and Tanzania (Tanganyika, Nambawala plateau, Pilepile). Early Albian of France (Aude, Padern, SLD 4514) and Spain (Castilla la Vieja, Cabo de Ajo, SLD 4686).

Early Albian Mexico (Baja California Norte, El Progreso; ERNO L-4391). Early Cenomanian of Germany (Nordrhein/Westfalen, Mülheim/Ruhr; Sachsen, MeißenZscheila) and Greece (Kozani, Nea Nikopolis, SLD 5876). Middle Cenomanian of Belgium (Hainaut, Montignies-surRoc, IRScNB I. G. 4919 / LOE 5).

Range: Late Barremian to Middle Cenomanian.

\section{SUMMARY}

The coral species described here are common cosmopolitan species found during the same general time span, with the exception of Columnocoenia aragonensis, which spans a wider period. All species were found elsewhere in comparable facies (such as the Early Aptian of the Isle of Wight, the Early Cretaceous of Tanzania, the Albian of Padern in France or Cabo de Ajo in Northern Spain, Cenomanian of Germany and Belgium), but also in transitional zones (such as the outcrops in Mexico) and pure carbonates (Early Cretaceous of Slovenia and Serbia, Early Aptian of Benicassim in Spain). Their morphology (plocoid colony with reduced coenosteum, small calices) suggests that they should be considered species that are well adapted to difficult environments (Sanders \& Baron-Szabo, 2005).

\section{ACKNOWLEDGEMENTS}

Preparation of thin sections was covered by DGPAPA PAPIIT Project IN107803 (UNAM, Mexico). For grammatical correction we would like to thank Kimberley Franklin (Tucson) very much. 


\section{REFERENCES}

Alloiteau, J. 1946-47. Polypiers du Gargasien aragonais. Anales de la Escuela de Peritos Agrícolas y de Especialidades Agropecuarias y de los Servicios Técnicos de Agricultura, 6, 187-243.

Alloiteau, J. 1952. Embranchement des coelentérés. In: Traité de Paléontologie (Ed. J. Piveteau). Masson, Paris, 376-684.

Arias, C., Masse, J.P. \& Vilas, L. 1993. Caracterización secuencial y bioestratigráfica del Aptiense-Albiense p. p. en la Sierra Sopalmo, Prebético Interno (Prov. de Murcia). Boletín geológico y minero, 104, 603-612.

Baron-Szabo, R.C. \& González León, C. M. 2003. Late Aptian-Early Albian corals from the Mural Limestone of the Bisbee Group (Tuape and Cerro de Oro areas), Sonora, Mexico. Special Publications in Geology, 187-225.

Bataller, J. 1959. Primer suplemento a la $<$ Sinopsis de las especies nuevas del Cretáceo de España>. Boletín del Instituto Geológico y Minero de España, 70, 1-77.

Blumenbach, J.F. 1805. Abbildungen naturhistorischer Gegenstände, Heft 8. Dietrich, Göttingen, 9 pp.

Bourne, G.C. 1900. The Anthozoa. In: Treatise on Zoology. Part 2: Porifera and Coelenterata. A. \& C. Black, London, 59-79.

Dietrich, W.O. 1926. Steinkorallen des Malms und der Unterkreide im südlichen Deutsch-Ostafrika. Palaeontographica, (suppl.7), 1, 43-62.

Fitton, W.H. 1847. A stratigraphical account of the section from Atherfield to Rocken End, on the south-west coast of the Isle of Wight. Quarterly Journal of the Geological Society of London, 3, 289-327.

Fromentel, E. de 1883. Zoophytes, terrain crétacé (12). Paléontologie française (A. d'Orbigny ed.), 8, 513-528.

Lamouroux, J.V.F. 1821. Exposition méthodique des genres de l'ordre des polypiers. Agasse, Paris, $115 \mathrm{pp}$.

Lonsdale, W. 1849. Notes on fossil Zoophytes found in the deposits described by Dr.Fitton in his Memoir entitled „A stratigraphical account of the section from Atherfield to Rocken End“. Quarterly Journal of the Geological Society of London, 5, 55-103.

Löser, H. 1989. Die Korallen der sächsischen Oberkreide (1:) Hexacorallia aus dem Cenoman. Abhandlungen des Staatlichen Museums für Mineralogie und Geologie zu Dresden, 36, 88-154.

Löser, H. 1994. La faune corallienne du mont Kassenberg à Mülheim-sur-la-Ruhr (Bassin crétacé de Westphalie, Nord Ouest de l'Allemagne). Coral Research Bulletin, 3, 1-93.

Löser, H. 2006. Taxonomy, stratigraphic distribution and palaeobiogeography of the Early Cretaceous coral genus Holocystis. Revista mexicana de ciencias geológicas, $\mathbf{2 3 ,}$ 288-301.

Morycowa, E. 1964. Hexacoralla des couches de Grodziszcze (Néocomien Carpathes). Acta Palaeontologica Polonica, 9, 1-114.

Morycowa, E. 1971. Hexacorallia et Octocorallia du Crétacé inférieur de Rarau (Carpathes orientales roumaines). Acta Palaeontologica Polonica, 16, 1-149.
Morycowa, E. 1989. Class Anthozoa Ehrenberg, 1834. In: Geology of Poland (3:) Atlas of guide and characteristic fossils (2c:) Mesozoic, Cretaceous (Ed. L. Malinowski). Wydawnictwa Geologiczne, Warszawa, 58-67.

Morycowa, E., Masse, J.P., Vilas, L. \& Arias, C. 2001. Montlivaltia multiformis Toula (Scleractinia) from the Aptian of the Prebetic domain (SE Spain). Revista Española de Paleontología, 16, 131-144.

Orbigny, A. de 1850. Prodrôme de Paléontologie stratigraphique universelle des animaux mollusques et rayonnés (1-2). Masson, Paris, 394 pp.

Prever, P.L. 1909. Anthozoa. In: La fauna coralligena del Cretaceo dei Monti d'Ocre nell 'Abbruzzo Aquilano (Ed. C.F. Parona). Memorie descrittive della carta geologica d'Italia, 5, 51-147.

Ryder, T.A. 1927. The structure and development of Holocystis Ed. and Haime. Geological Magazine, 64, 119-122.

Sanders, D. \& Baron-Szabo, R.C. 2005. Scleractinian assemblages under sediment input: their characteristics and relation to the nutrient input concept. Palaeogeography, Palaeoclimatology, Palaeoecology, 216, 139-181.

Schöllhorn, E. 1998. Geologie und Paläontologie des Oberapt im Becken von Organyà (Nordspanien). Coral Research Bulletin, 6, 1-139.

Stafford-Smith, M.G. \& Ormond, R. F. G. 1992. Sedimentrejection mechanisms of 42 species of Australian scleractinian corals. Australian Journal of Marine and Freshwater Research, 43, 683-705.

Tomás, S., Löser, H. \& Salas Roig, R. 2008, in press. Facies changes and coral associations in a Lower Aptian carbonate platform of the soutwestern Maestrat Basin (Iberian Chain, eastern Spain). Cretaceous Research.

Toula, F. 1889. Geologische Untersuchungen im centralen Balkan. Denkschriften der Kaiserlichen Akademie der Wissenschaften, Mathematisch-Physikalische Klasse, 55, 1-108.

Turnšek, D. \& Buser, S. 1976. Knidarijska favna iz senonijske brece na Banjski Planoti. Razprave Slovenska akademija znanosti in umetnosti, (4), 19, 37-88.

Turnšek, D. \& Mihajlović, M. 1981. Lower Cretaceous Cnidarians from eastern Serbia. Razprave Slovenska akademija znanosti in umetnosti, (4), 23, 1-54.

Vaughan, T.W. \& Wells, J.W. 1943. Revision of the suborders, families and genera of scleractinia. Special Papers. Geological Society of America, 44, 1-363.

Vilas, L., Martín-Chivelet, J., Arias, C., Giménez, R., RuizOrtiz, P.A., Castro, J.M., Masse, J.P. \& Estévez, A. 1998. Cretaceous carbonate platforms of the Spanish Levante. Sedimentary evolution and sequence stratigraphy. 15th International Sedimentological Congress. Field trip guidebook, 293-315.

Volz, W. 1903. Über eine Korallenfauna aus dem Neokom der Bukowina. Beiträge zur Paläontologie und Geologie Österreich-Ungarns und des Orients, 15, 1, 9-30.

Manuscrito recibido: 25 de Abril, 2007 Manuscrito aceptado: 10 de Diciembre, 2007 


\title{
PRESENCIA DE MACRORRESTOS PARAUTÓCTONOS DE Sabalites cf. longirhachis (UNGER, 1850) KVAČEK \& HERMAN, 2004 EN FACIES PARÁLICAS DEL CRETÁCICO SUPERIOR DEL PIRINEO ORIENTAL
}

\author{
Josep MARMI ${ }^{1,2}$, Bernard GOMEZ ${ }^{3}$ y Carles \\ MARTÍN-CLOSAS \\ ${ }^{1}$ Institut Català de Paleontologia, C/ Escola Industrial 23, E-08201 Sabadell \\ (Barcelona).josep.marmi@icp.cat \\ ${ }^{2}$ Consorci Ruta Minera, Carretera de Ribes 20, E-08698 Cercs (Barcelona) \\ ${ }^{3}$ CNRS-UMR 5125, Paléoenvironnements et Paléosphère, Université Lyon 1, \\ 43 Bd du 11 Novembre 1918, F-69622 Villeurbanne cedex, France. \\ bernard.gomez@univ-lyon1.fr \\ ${ }^{4}$ Departament d'Estratigrafia, Paleontologia i Geociències Marines, Universitat \\ de Barcelona, c/ Martí i Franquès s/n, E-08028 Barcelona. \\ cmartinclosas@ub.edu.
}

\begin{abstract}
Marmi, J., Gomez, B. \& Martín-Closas, C. 2008. Presencia de macrorrestos parautóctonos de Sabalites cf. longirhachis (Unger, 1850) Kvaček \& Herman, 2004 en facies parálicas del Cretácico Superior del Pirineo oriental [Occurrence of parauthocthonous megaremains of Sabalites cf. longirhachis (Unger, 1850) Kvaček \& Herman, 2004 in paralic facies from the Upper Cretaceous of the Eastern Pyrenees.] Revista Española de Paleontología, 23 (1), 7-14. ISSN 0213-6937.
\end{abstract}

\begin{abstract}
Costapalmate leaf adpressions of Sabalites cf. longirhachis have been recently discovered from the Upper Cretaceous sites of Fumanya (Berguedà) and Pinyes (Alt Urgell) in the Eastern Pyrenees. Moreover, the Fumanya outcrops supply significant data for the habitat of this plant in brackish coastal swamps.
\end{abstract}

Keywords: Arecaceae, Sabalites, Fumanya, Eastern Pyrenees, Maastrichtian.

RESUMEN

En los yacimientos del Cretácico Superior de Fumanya (Berguedà) y Pinyes (Alt Urgell), en el Pirineo Oriental, se han descubierto recientemente adpresiones de hojas costapalmadas atribuidas a Sabalites cf. longirhachis. El yacimiento de Fumanya proporciona datos relevantes sobre el hábitat de esta planta en marismas costeras salobres.

Palabras clave: Arecaceae, Sabalites, Fumanya, Pirineo Oriental, Maastrichtiense.

\section{INTRODUCCIÓN}

Los restos más antiguos de palmeras fósiles consisten en hojas costapalmadas del Coniaciense-Campaniense inferior de América del Norte y Europa (Berry, 1905, 1911, 1914; Kvaček \& Herman, 2004). Desde finales del Cretácico superior la mayoría de taxones dentro de Arecaceae, familia de monocotiledóneas que incluye las palmeras, ya están presentes en el registro fósil (Harley, 2006). En general, las monocotiledóneas son relativamente escasas en el registro de macroflora, siendo más abundantes en las pali- nofloras. Sin embargo, los restos fósiles de hojas, troncos, raíces, frutos y semillas atribuidos a la familia Arecaceae están bien documentados en la literatura (ver revisión en Harley, 2006). En un artículo reciente sobre la flora de la Formación Grünbach (Alpes orientales, Austria) se documentan unos de los restos más antiguos de palmeras en Europa (Kvaček \& Herman, 2004). Se trata de restos de hojas costapalmadas del Campaniense inferior, clasificados como Sabalites longirhachis (Unger, 1850) Kvaček \& Herman, 2004. Los mismos autores sugieren incluir dentro de este parataxon a Juranyia hemiflabellata Tuzson, 1908, 
del Maastrichtiense de Rumania, ya que presenta también morfología costapalmada. En el sur de Francia Sabalites longirhachis (Unger, 1850) Kvaček \& Herman, 2004 fue citado previamente en el Campaniense-Maastrichtiense de la localidad de Fuveau (Saporta, 1890) y, en el Pirineo Oriental, ha sido citado en las cercanías del pueblo de Isona (cuenca de Tremp) a partir de material fragmentado (Vicente, 2002).

Sabalites longirhachis (Unger, 1850) Kvaček \& Herman, 2004 representaría la forma primitiva a partir de la cuál pudieron evolucionar las hojas pinnadas y palmadas (Kvaček \& Herman, 2004). Esta forma estaría caracterizada por presentar una morfología costapalmada, induplicada, simple y con segmentos foliares totalmente fusionados o, a veces, mínimamente diseccionados en su parte apical (Kvaček \& Herman, 2004). Aunque no se conoce con certitud el pariente vivo más cercano de Sabalites, se ha sugerido, en base a datos moleculares, que la subfamilia Coryphoideae, que contiene palmeras con hojas costapalmadas, seria uno de los grupos basales dentro de Arecaceae (Lewis \& Doyle, 2001). Sin embargo, otros estudios moleculares indican que Coryphoideae sería el grupo hermano de las subfamilias Arecoideae y Ceroxyloideae, quedando sólo Nypoideae y Calamoideae como grupos basales (Hann, 2002; Asmussen et al., 2006).

Recientemente, se han descubierto impresiones de hojas de palmeras costapalmadas en los yacimientos del área de Fumanya, en los municipios de Fígols y Vallcebre (Berguedà, Barcelona) y de Pinyes, en el municipio de Coll de Nargó (Alt Urgell, Lleida) (Fig. 1). En el presente trabajo describimos la morfología de estos especimenes y presentamos por primera vez una hipótesis tafonómica y autecológica sobre el hábitat de Sabalites longirhachis (Unger, 1850) Kvaček \& Herman, 2004.

\section{CONTEXTO GEOLÓGICO}

Los yacimientos de Fumanya (sinclinal de Vallcebre) fueron descubiertos en 1985 (Viladrich, 1986) y consisten en cuatro afloramientos de capas subverticales donde se pueden observar millares de icnitas y varias decenas de rastros asignados a saurópodos titanosaurios (véase referencias en Vila et al., 2005). Los afloramientos donde se han localizado las impresiones de hojas son Fumanya Sur y Mina Esquirol. Ambas localidades se localizan en los materiales basales de la Formación Tremp (Mey et al., 1968), dentro del clásicamente llamado "Garumniense" gris (Rosell et al., 2001). En el sinclinal de Vallcebre, los restos vegetales estudiados se incluyen en la parte superior de la unidad "Calizas margosas" conocida como "cementos", de acuerdo con Aepler (1967) y Rosell et al. (2001), y que presenta una edad Maastrichtiense inferior (Oms et al., 2007) (Fig. 2). Además de las calizas margosas, la unidad regional del Garumniense gris presenta una alternancia de calizas lacustres con margas orgánicas y carbones (lignitos) que se depositó bajo condiciones reductoras, en un ambiente de marisma supra-mareal (Rosell et al., 2001). La presencia de carofitas de aguas salobres (poblaciones homogéneas de Feistiella sp.) en niveles inmediatamente

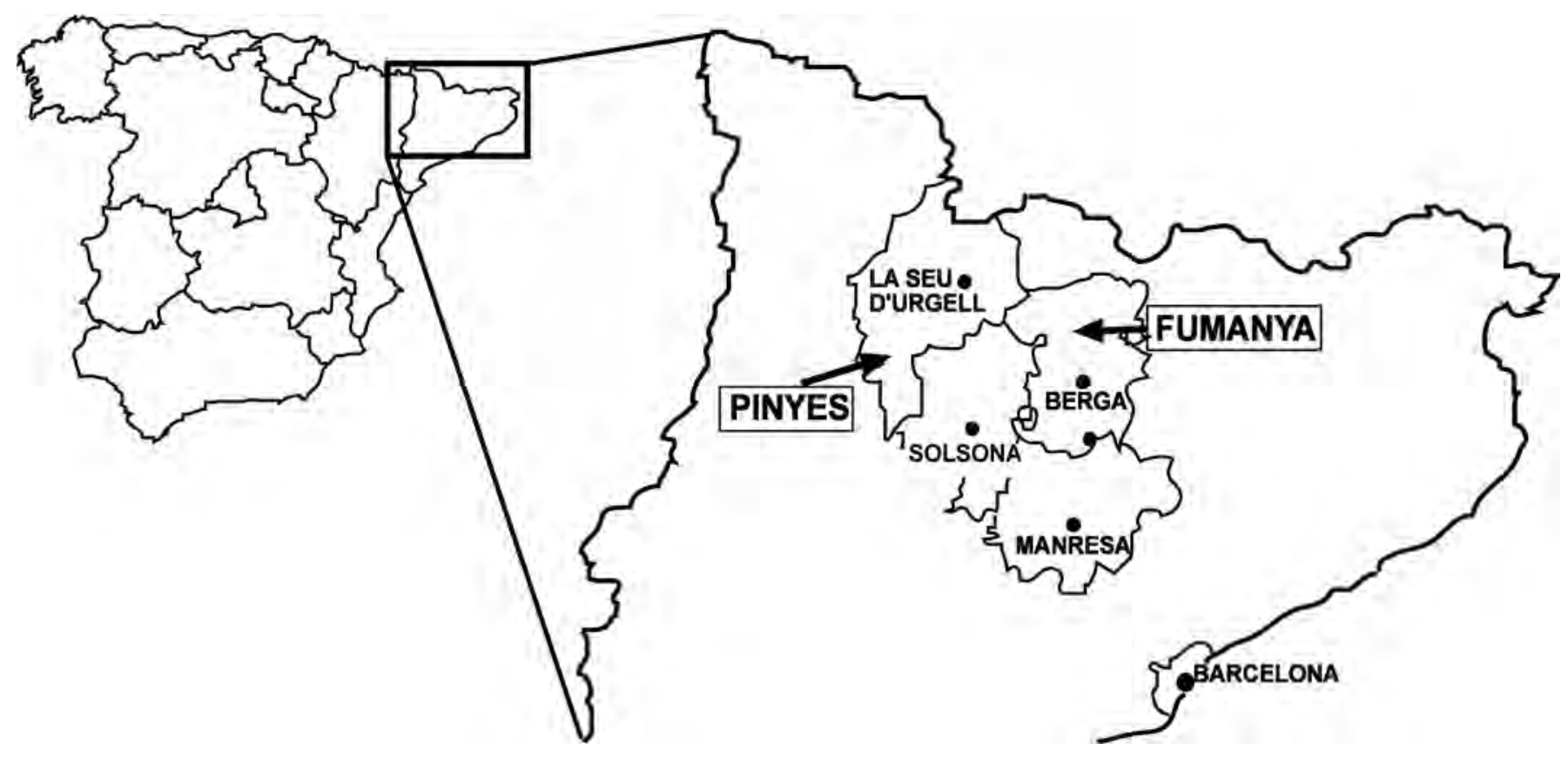

Figura 1. Localización geográfica de los yacimientos de Fumanya y Pinyes.

Geographic location of Fumanya and Pinyes sites. 


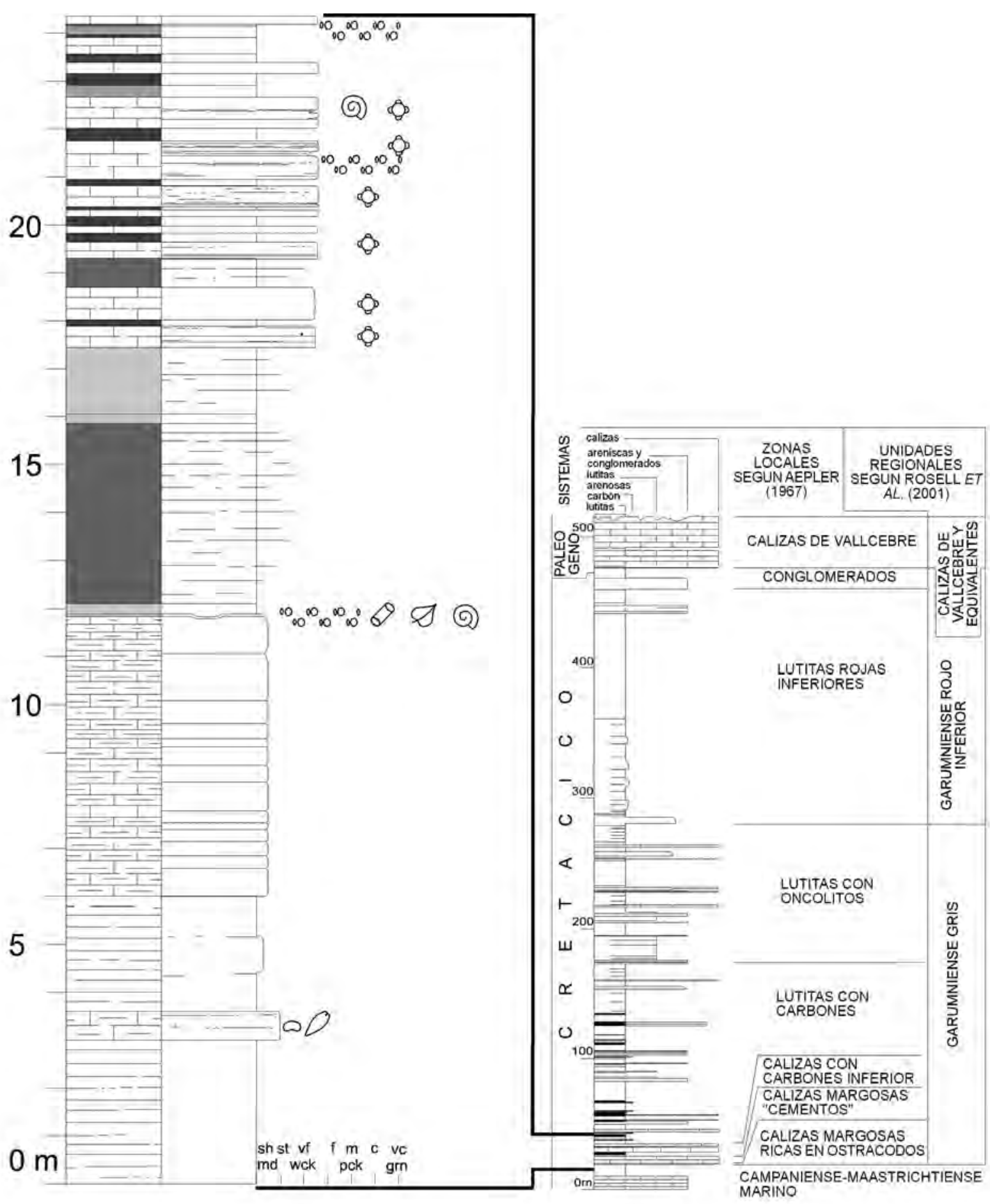

\section{LEYENDA} y lignitos
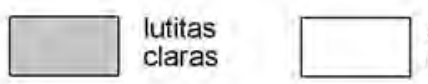

areniscas claras
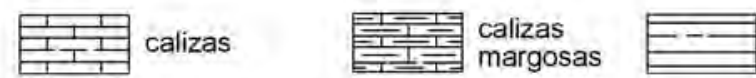

margas

carófitas $\varnothing$ impresiones de hojas de Sabalites

$\theta$ burrowing 0 bivalvos (Q) gasterópodos

ostrácodos $\quad{ }_{10}^{10} \% 0^{\circ} \times 0^{\circ 0} 10^{\circ}$ icnitas de dinosaurio

Figura 2. Serie estratigráfica sintética de Fumanya (modificada de Vila et al., 2005) con la localización del nivel rico en hojas de Sabalites cf. longirhachis (Unger, 1850) Kvaček \& Herman, 2004.

Synthetic stratigraphy of Fumanya (modified from Vila et al., 2005) with the location of the level rich in leaves of Sabalites cf. longirhachis (Unger, 1850) Kvaček \& Herman, 2004. 
suprayacentes a los que han proporcionado las hojas de palmeras sugieren que en la marisma predominaban las condiciones salobres. Feist \& Colombo (1983) también señalan la presencia de una fauna de ostrácodos salobres en estos niveles (Cyprideis sp., Neocyprideis durocortoriensis Apostolescu, 1956). La presencia de niveles monopespecíficos de Corbicula laletana Vidal, 1874 viene a apoyar igualmente el carácter salobre de la sucesión.

El yacimiento de Pinyes es conocido por su abundante registro de huevos y puestas de dinosaurios (Escuer et al., 2003). En el área de Coll de Nargó los restos vegetales se incluyen en el tramo de calizas basales y margas grises, con niveles de carbones. Estratigráficamente se encuentran por encima de los materiales costeros de la Formación Areniscas de Arén. Su edad podría variar entre Campaniense superior y Maastrichtiense inferior (Feist \& Colombo, 1983).

\section{PALEONTOLOGÍA SISTEMÁTICA}

\author{
Clase LILIOPSIDA Scopoli, 1760 \\ Orden ARECALES Bromhead, 1840 \\ Familia Arecaceae Schultz-Schultzenstein, 1832 \\ Género Sabalites Saporta, 1865

\section{Sabalites cf. longirhachis (Unger, 1850) Kvaček \& Herman, 2004} \\ Fig. 3, Tab. 1
}

Material: Los ejemplares estudiados son los siguientes: BFUM15 (IPS-41681), impresión de lámina conservada casi totalmente (Fig. 3a); B-FUM16 (IPS-41682), impresión de hoja completa, incluyendo el pecíolo (Fig. 3b); V-FUM86, impresión parcial de lámina y de un fragmento de pecíolo (Fig. 3c); V-FUM137, impresión de unas 3/4 partes de la lámina y pecíolo (Fig. 3d); V-FUM185, impresión bastante erosionada de la mitad basal de la lámina y una parte del pecíolo (Fig. 3e); V-FUM223, impresión parcial de lámina donde la parte más completa corresponde a la mitad de la base (Fig. 3f); IPS-41683, impresión de la parte basal de la lámina y parte del pecíolo (Fig. 3g). Las impresiones originales se encuentran en los yacimientos de Mina Esquirol (B-FUM15, B-FUM16, V-FUM223), Fumanya Sur (V-FUM86, V-FUM137, V-FUM185) y Pinyes (sin catalogar). Algunos de los ejemplares, especialmente en los afloramientos de Fumanya, no se han excavado completamente debido a su fragilidad, pues su extracción supondría su destrucción y la exposición total a la intemperie puede suponer su pérdida irreversible por erosión a corto-medio plazo. Se han realizado réplicas de los especimenes de Fumanya (B-FUM15 y B-FUM16) y de Pinyes, que se encuentran depositadas en el Institut Català de Paleontologia bajo las siglas (IPS-41681, IPS-41682 y IPS41683 respectivamente). El molde se realizó con silicona y fibra de vidrio y la réplica con resina soluble en agua. Las medidas se han realizado directamente en las impresiones excepto en VFUM185 y V-FUM223, recurriendo en estos casos a la ayuda de fotografías debido a las dificultades de acceso. Los ángulos de inserción de los segmentos se han medido a partir de fotografías en todos los casos.

Descripción: Las hojas son costapalmadas y ovalo-lanceoladas. Las láminas más completas (Fig. 3a y b) miden entre 43 y $75 \mathrm{~cm}$ de longitud y entre 10 y $41 \mathrm{~cm}$ de ancho. Están formadas por entre unos 25 (B-FUM16) y 30 (B-FUM15) pares de segmentos foliares opuestos, induplicados (su sección transversal tiene forma de V), rectilíneos (o ligeramente curvados en la base) y totalmente fusionados o, a veces, ligeramente diseccionados en los márgenes (Fig. 3a y b). Los segmentos que nacen en la parte basal de la lámina son más delgados que los de las partes medial y apical. En B-FUM15 miden un promedio de $44 \mathrm{~cm}$ y en B-FUM16 unos $20 \mathrm{~cm}$ de longitud mientras que la anchura de los segmentos varía entre 0,35 y $1,4 \mathrm{~cm}$. Los segmentos pueden ser más estrechos en su base que en los márgenes de la lámina (Fig. 3a), se unen en la costa formando un ángulo agudo (entre $10-30^{\circ}$ en hojas pequeñas y entre 30 y $50^{\circ}$ en las hojas de mayor tamaño) y son ligeramente decurrentes en la parte apical de esta estructura (Fig. 3a). La costa es larga (hasta 35 $\mathrm{cm}$ de longitud), delgada y se introduce hasta aproximadamente la mitad de la lámina (Fig 3a y b). En los segmentos se puede distinguir un nervio central y otros de órdenes inferiores paralelos, a cada lado del principal. El pecíolo tiene más de medio metro de longitud y puede superar la longitud de la lámina (Fig. 3b). Puede presentar finas estriaciones longitudinales (Fig. 3d). Las medidas efectuadas en los diferentes especímenes se resumen en la Tabla 1.

Discusión: De acuerdo con Read \& Hickey (1972), el género Sabalites incluye hojas de arecáceas de morfología costapalmada. Sin embargo este tipo de morfología también aparece en otros géneros como el extinto Geonomites Lesquereux, 1878 (Campaniense) y el actual Sabal Adanson, 1763. A falta de una revisión detallada, el género Geonomites se diferencia de Sabalites en caracteres sutiles como la mayor longitud de las bases decurrentes de los segmentos foliares al unirse a la costa. Las diferencias

Figura 3. Sabalites cf. longirhachis (Unger, 1850) Kvaček \& Herman, 2004 del Cretácico Superior del Pirineo Oriental. Impresiones de las hojas estudiadas en este trabajo. a, B-FUM15 (IPS-41681); b, B-FUM16 (IPS-41682); c, V-FUM86; d, V-FUM137; e, V-FUM185; f, V-FUM223; g, IPS-41683. Las escalas son las siguientes: $5 \mathrm{~cm}$ en a y c; $15 \mathrm{~cm}$ en b y f; $6 \mathrm{~cm}$ en d; 25 $\mathrm{cm}$ en e. La brocha de $\mathbf{g}$ mide $20 \mathrm{~cm}$.

Sabalites $c f$. longirhachis (Unger, 1850) Kvaček \& Herman, 2004 from the Upper Cretaceous of Eastern Pyrenees. Impressions of leaves studied. a, B-FUM15 (IPS-41681); b, B-FUM16 (IPS-41682); c, V-FUM86; d, V-FUM137; e, V-FUM185; $\boldsymbol{f}$, V-FUM223; $\boldsymbol{g}$, IPS-41683. The scale bars correspond to: $5 \mathrm{~cm}$ in $\boldsymbol{a}$ and $\boldsymbol{c} ; 15 \mathrm{~cm}$ in $\boldsymbol{b}$ and $\boldsymbol{f} ; 6 \mathrm{~cm}$ in $\boldsymbol{d} ; 25 \mathrm{~cm}$ in $\boldsymbol{e}$. The paintbrush from $\mathrm{g}$ is $20 \mathrm{~cm}$ long. 


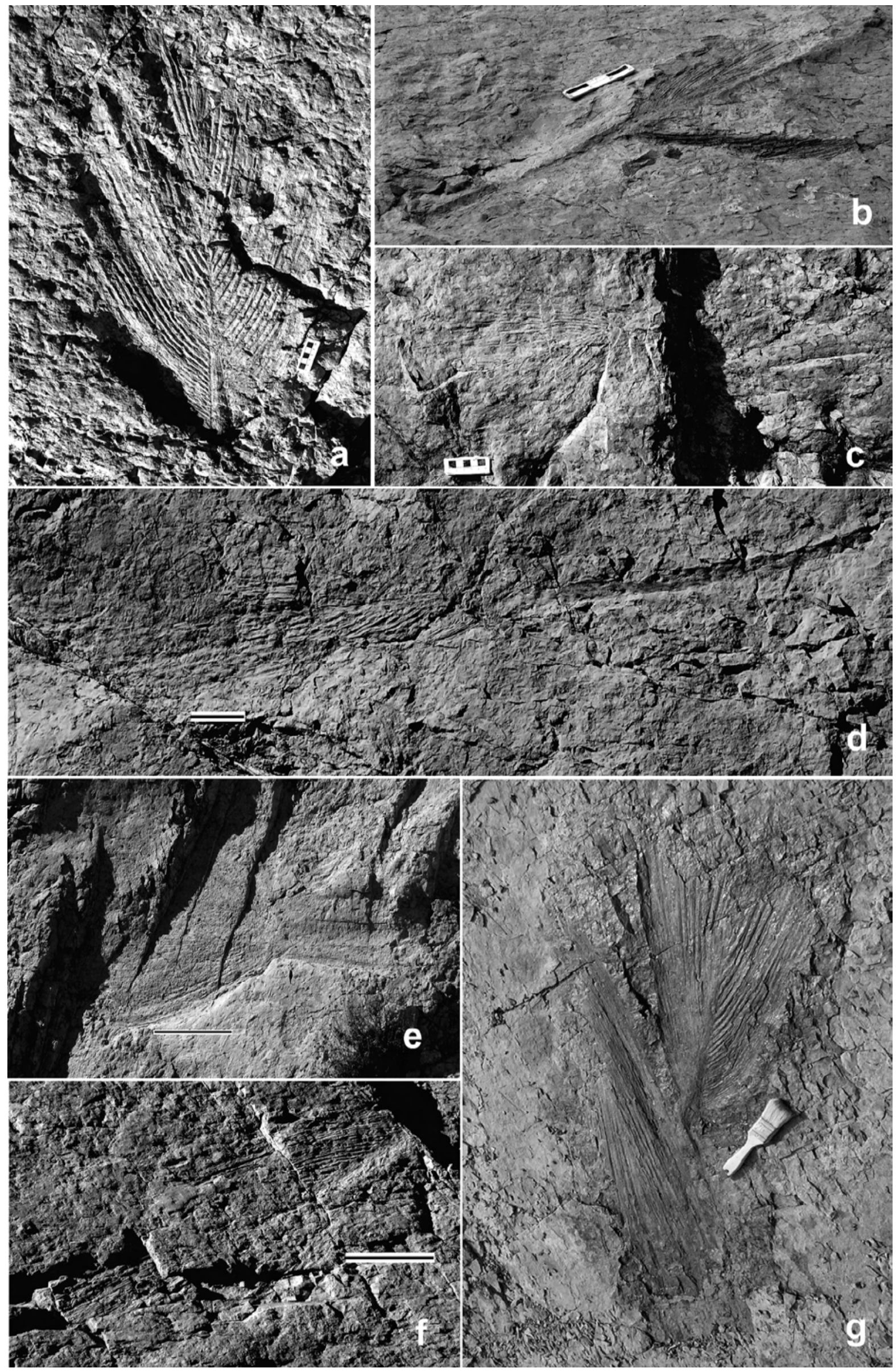




\begin{tabular}{|c|c|c|c|c|c|c|c|}
\hline & $\begin{array}{c}\text { B-FUM15 } \\
\text { (IPS-41681) }\end{array}$ & $\begin{array}{c}\text { B-FUM16 } \\
\text { (IPS-41682) }\end{array}$ & V-FUM86 & V-FUM137 & V-FUM185 & V-FUM223 & IPS-41683 \\
\hline Longitud total $(\mathrm{cm})$ & - & 96 & - & - & - & - & - \\
\hline Longitud lámina $(\mathrm{cm})$ & $75^{*}$ & 43 & - & $50-60$ & - & - & - \\
\hline Anchura lámina $(\mathrm{cm})$ & 41 & 10 & - & - & 60 & - & - \\
\hline Longitud pecíolo (cm) & - & 53 & - & - & - & - & - \\
\hline Anchura pecíolo (cm) & - & $2,15-4,7$ & 5,6 & 2,5 & - & - & - \\
\hline Longitud costa $(\mathrm{cm})$ & 30 & 15 & 10,3 & 20 & - & - & 35 \\
\hline Anchura costa en la base $(\mathrm{cm})$ & 3,6 & 2,0 & - & 1,85 & - & - & 3,2 \\
\hline Longitud segmentos $(\mathrm{cm})$ & $42-47$ & $18-22$ & - & - & - & - & - \\
\hline Anchura segmentos $(\mathrm{cm})$ & $1,0-1,4$ & $0,35-0,6$ & $0,4-0,8$ & 0,6 & - & - & $0,4-1,0$ \\
\hline Ángulo segmentos-costa & $30^{\circ}-50^{\circ}$ & $10^{\circ}-25^{\circ}$ & $25^{\circ}-30^{\circ * *}$ & $10^{\circ}-30^{\circ}$ & - & $30^{\circ * * *}$ & $15^{\circ}-45^{\circ}$ \\
\hline
\end{tabular}

Tabla 1. Valores de las medidas efectuadas en las hojas costapalmadas de los yacimientos de Fumanya y Pinyes. Leyenda: * lámina casi completa; $* *$ en segmentos de la mitad apical y parte medial de la costa; $* * *$ en segmentos de la parte medial de la costa.

Size values of costapalmate leaves from Fumanya and Pinyes sites. Caption: *almost complete lamina, **in segments from half apical and medial part of costa, *** in segments from the medial part of costa.

respecto a Sabal son más evidentes ya que en este género los segmentos están profundamente diseccionados mientras que en Sabalites están fusionados prácticamente hasta los márgenes de la lámina. Ninguno de los caracteres que diferencian Geonomites y Sabal está presente en los ejemplares de Fumanya y Pinyes. En Kvaček \& Herman (2004) se indican los principales caracteres morfológicos que pueden ser diagnósticos para distinguir el parataxón estudiado en este trabajo de las paraespecies descritas en el Cretácico Superior y Paleógeno de América del Norte. Sabalites carolinensis Berry, 1914, del Santoniense de Carolina del Sur (Estados Unidos) presenta una costa corta y segmentos estrechos en forma de cuña y divididos en los extremos. Sabalites ungeri (Lesquereux, 1878) Dorf, 1939, del Paleoceno de Nuevo México (Estados Unidos) presenta una costa robusta y estriada. Las otras especies paleógenas aceptadas por Read \& Hickey (1972) se caracterizan por tener una costa muy corta en comparación con Sabalites longirhachis (Unger, 1850) Kvaček \& Herman, 2004, según (Kvaček \& Herman, 2004). Sabal dortchii Daghlian, 1978, del Eoceno de Tennessee (Estados Unidos) presenta una costa alargada pero puede diferenciarse de Sabalites a partir de características de la cutícula.

Las características morfológicas de los especimenes descritos en este trabajo coinciden en su totalidad con la mayoría de caracteres diagnósticos de Sabalites longirhachis (Unger, 1850) Kvaček \& Herman, 2004. La diagnosis de esta especie se basa en: (1) hojas costapalmadas, induplicadas y lanceoladas; (2) hojas con costa larga y estrecha; (3) segmentos fusionados, algunas veces ligeramente diseccionados en los márgenes de la hoja, rectilíneos, ligeramente más anchos hacia el ápice, uniéndose a la costa en un ángulo agudo y unidos decurrentemente a la parte apical de esta estructura (Kvaček \& Herman, 2004). Según estos autores, la diagnosis de Sabalites longirhachis también se basa en caracteres histológicos y de morfología celular: cada segmento tiene un nervio principal central y otros paralelos a este organizados en cuatro órdenes diferentes, las cutículas abaxial y adaxial tienen células alongadas y la cutícula abaxial estomas tetracíticos. Las convergencias morfológicas son menos probables en estos últimos caracteres pero hasta el momento no se dispone de detalles cuticulares en los ejemplares del Pirineo. En este sentido, de acuerdo con los caracteres morfológicos disponibles, asignamos los ejemplares descritos en este trabajo a Sabalites cf. longirhachis.

\section{TAFONOMÍA Y PALEOAUTECOLOGÍA}

Los especimenes de Fumanya representan el material más completo a nivel macroscópico de este parataxón descrito hasta el momento. Los ejemplares descritos por Vicente (2002) en Isona y por Kvaček \& Herman (2004) en Austria son fragmentados y en ningún caso conservan el pecíolo en conexión anatómica con el limbo. Es muy probable que las partes que faltan en los ejemplares estudiados [excepto B-FUM16 (IPS-41682), que se ha conservado en su totalidad] se hayan perdido por erosión y que originalmente las hojas fosilizaran enteras. Desde el punto de vista tafonómico la presencia de la hoja entera, incluyendo lámina y pecíolo en conexión anatómica, son muy significativos ya que la mayoría de palmeras presentan hojas marcescentes, que se degradan sobre la 
planta una vez muertas, incluso recubriendo el tronco en su totalidad, lo que dificulta su entrada en el registro fósil en un buen estado de conservación (Martín-Closas \& Gomez, 2004). La conservación de la hoja entera indicaría un tipo de producción tafonómica traumática y un hábitat cercano al ambiente deposicional (marisma litoral salobre).

Otro dato interesante de las impresiones de hojas de Fumanya es la posible conservación de diversos estadios de crecimiento. A partir de las dimensiones de la lámina, de la costa y de los ángulos de inserción de los segmentos a la costa (Tabla 1), se sugiere que las impresiones B-FUM16 (IPS-41682), V-FUM86 y V-FUM137 corresponderían a hojas jóvenes y el resto a hojas adultas. La conservación de diferentes estadios de crecimiento en el mismo nivel viene a apoyar la hipótesis de un hábitat cercano al medio deposicional para los restos estudiados.

\section{CONCLUSIONES}

Se describe la presencia de hojas costapalmadas muy bien conservadas de Sabalites cf. longirhachis en el Campaniense y Maastricthiense del Pirineo oriental. Estas hojas representan el macrorresto más completo hallado hasta el momento de este parataxón. Los fósiles son parautóctonos en los niveles de margas intercaladas con lignitos de la Formación Tremp en los afloramientos de Fumanya, Mina Esquirol y Pinyes. Estos niveles se han atribuido a facies de marisma parálica salobre, en las que se sugiere que viviría la planta.

\section{AGRADECIMIENTOS}

El trabajo de campo fue posible gracias al permiso de prospección concedido por la Direcció General de Patrimoni Cultural (Departament de Cultura i Mitjans de Comunicació, Generalitat de Catalunya). Este estudio ha sido financiado por los proyectos 2006EXCAVA0001 (Generalitat de Catalunya), CGL2005-00046, CGL2005-01121 y CGL2005-00404 (Ministerio de Educación y Ciencia). Agradecemos al Dr Ángel Galobart (Institut Català de Paleontologia), a Josep Peralba (Coll de Nargó), al Dr Oriol Oms (Universitat Autónoma de Barcelona) y a Bernat Vila (ICP) su ayuda en diversos aspectos de la realización del trabajo.

Josep Marmi es investigador postdoctoral (Programa Juan de la Cierva) del ICP.

\section{REFERENCIAS BIBLIOGRÁFICAS}

Adanson, M. 1763. Familles des Plantes, 2 vol., Paris, Vincent. Aepler, R. 1967. Das Garumnian der Mulde von Vallcebre und ihre Tektonik (Spanien, Provinz Barcelona). Master thesis der Freien Universität Berlin (Naturwissenschftlichen Fakultät), 101 pp. (inédito).
Asmussen, C.B., Dransfield, J., Deickmann, V., Barfod, A.S., Pintaud, J.C. \& Baker, W.J. 2006. A new subfamily classification of the palm family (Arecaceae): evidence from plastid DNA phylogeny. Botanical Journal of the Linnean Society, 151, 15-38.

Berry, E.W. 1905. A palm from the mid-Cretaceous. Torreya, 5, 30-33.

Berry, E.W. 1911. Contributions to the Mesozoic flora of the Atlantic coastal plain-VII. Butlletin of the Torrey Botanical Club, 38, 399-424.

Berry, E.W. 1914. The Upper Cretaceous and Eocene floras of South Carolina and Georgia. US Geological Survey Professional Paper, 84, 5-200.

Daghlian, C.P. 1978. Coryphoid palms from the lower and middle Eocene of southeastern North America. Palaeontographica $B, \mathbf{1 6 6}, 44-82$.

Dorf, E. 1939. Fossil plants from the Upper Cretaceous Aguja Formation of Texas. American Museum Novitates, 1015, 1-9.

Escuer, J., Peralba, J., Cusso, R., Jimenez, A., Borrull, J., Perez, P., Umbert, M., Garrabou, E., Bons, N., Garrabou, M. \& Regal, C. 2003. Sallent Valley, recurrent dinosaur nesting site from the Late Cretaceous of southern Pyrenees (Coll de Nargó, Spain): a GIS approach. Abstract 2nd Int. Symposium on Dinosaur Eggs and Babies, Montpellier, 11.

Feist, M. \& Colombo, F. 1983. La limite Crétacé-Tertiaire dans le nord-est de l'Espagne, du point de vue des charophytes. Géologie Méditerranéenne, 10, 303-326.

Hahn, W.J. 2002. A molecular phylogenetic study of the Palmae (Arecaceae) based on $a t p \mathrm{~B}, r b c \mathrm{~L}$, and $18 \mathrm{~S}$ nrDNA sequences. Systematic Biology, 51, 92-112.

Harley, M.M. 2006. A summary of fossil records for Arecaceae. Botanical Journal of the Linnean Society, 151, 39-67.

Kvaček, J. \& Herman, A.B. 2004. Monocotyledons from the Early Campanian (Cretaceous) of Grünbach, Lower Austria. Review of Palaeobotany and Palynology, 128 323-353.

Lesquereux, L. 1878. Contribution to the fossil flora of the Western Territories, Part II. The Tertiary flora. US Geological Survey Reports, VII, 1-366.

Lewis, C.E. \& Doyle, J.J. 2001. Phylogenetic utility of the nuclear gene Malate Synthase in the palm family (Arecaceae). Molecular Phylogenetics and Evolution, 19, 409-420.

Martín-Closas, C. \& Gomez, B. 2004. Taphonomie des plantes et interprétations paléoécologiques. Une synthèse. Geobios, 37, 65-888.

Mey, P.H., Nagtegaal, P.J.C., Roberti, K.J. \& Hartevelt, J.J.A. 1968. Lithostratigraphic subdivision of Post-Hercynian deposits in the South-Central Pyrenees, Spain. Leidse Geologische Mededelingen, 41, 221-228.

Oms, O., Dinarès-Turell, J., Vicens, E., Estrada, R., Vila, B., Galobart, À. \& Bravo, A.M. 2007. Integrated stratigraphy from the Vallcebre basin (southeastern Pyrenees, Spain): new insights on the continental Cretaceous-Tertiary transition in southwest Europe. Palaeogeography, Palaeoclimatology, Palaeoecology, 255, 35-47.

Read, R.W. \& Hickey, L.J. 1972. A revised classification of fossil palm and palm-like leaves. Taxon, 21, 129-137. 
Rosell, J., Linares, R. \& Llompart, C. 2001. El "Garumniense" Prepirenaico. Revista de la Sociedad Geológica de España, 14, 47-56.

Saporta, G. 1865. Études sur la vegetation du sud-est de la France a l'époque tertiaire. Annales des Sciences Naturelles, Botanique, 53, 1-152.

Saporta, G. 1890. Le Nelumbium provinciale des lignites crétacés de Fuveau en Provence. Mémoires de la Société Géologique de France, Paléontologie, 5, 1-10.

Tuzson, J. 1908. Adatok Magyarorszag fosszilis florajahoz (II). Additamenta ad floram fossilem Hungariae. Novenytani Kozlemenyek, 7, 1-4.

Unger, F. 1850. Genera et species plantarum fossilium.
Academia Caesareae Scientiarum, Wilhelm Braumueller, Vindobonae, $627 \mathrm{pp}$.

Vicente, J. 2002. Estudi morfológic de la flora cretácica d'Isona (Pallars Jussà). Institut d'Estudis de la Natura del Barcelonés Nord. Santa Coloma de Gramenet, 223 pp.

Vila, B., Oms, O. \& Galobart, A. 2005. Manus-only titanosaurid trackway from Fumanya (Maastrichtian, Pyrenees): further evidence for an underprint origin. Lethaia, 38, 211-218.

Viladrich, L. 1986. Les petjades fòssils del Coll de Fumanya. L'Erol, 18, 7-12.

Manuscrito recibido: 25 de Enero, 2007 Manuscrito aceptado: 12 de Diciembre, 2007 


\title{
EVOLUCIÓN PALEOAMBIENTAL DURANTE EL TRÁNSITO CRETÁCICO/PALEÓGENO BASADA EN FORAMINÍFEROS BENTÓNICOS
}

\author{
Laia ALEGRET BADIOLA
}

Departamento Ciencias de la Tierra, Universidad de Zaragoza. 50009 Zaragoza. laia@unizar.es

Alegret Badiola, L. 2008. Evolución paleoambiental durante el tránsito Cretácico/Paleógeno basada en foraminíferos bentónicos. [Paleoenvironmental turnover across the Cretaceous/Paleogene transition based on benthic foraminifera.] Revista Española de Paleontología, 23 (1), 15-30. ISSN 0213-6937

\begin{abstract}
The Cretaceous/Paleogene (K/Pg) boundary marks one of the largest mass extinctions in the Fanerozoic, affecting both marine and terrestrial communities. Most scientists accept that the K/Pg boundary extinction was caused, at least in part, by a meteorite impact north of Yucatan peninsula. Such an impact would trigger a series of anomalous deposits, with different characteristics depending on the distance from the impact site; moreover, it triggered a series of dramatic biological, oceanic and climatic changes. Although the impact hypothesis has been broadly accepted, it has originated an intense debate as to the direct or indirect mechanisms that caused the extinctions. Whereas planktic foraminifera and calcareous nannoplancton suffered important mass extinctions, benthic foraminifera do not show any mass extinction across the K/Pg boundary, but temporal changes in the composition of their assemblages. A synthesis of the evolution of benthic foraminiferal assemblages across the $\mathrm{K} / \mathrm{Pg}$ boundary in sections and cores from the Gulf of Mexico and North Atlantic, as well as from more distal areas such as Northern Pacific, South Atlantic and Tethys, is here presented.

Changes in benthic foraminiferal assemblages across the K/Pg boundary have been interpreted as the result of the collapse of the pelagic food web and the scarcity of food supply to the benthos, resulting from the mass extinction of calcareous plankton. However, changes in the composition of benthic assemblages after the K/Pg boundary were geographically variable, and there is no agreement as to the detailed paleoenvironmental interpretation of the assemblages (anoxic or eutrophic conditions in Spanish sections, oligotrophic conditions in Tunisian sections, high and unstable organic flux in N Pacific, etc).

There is evidence that productivity and food transfer to the sea floor recovered much faster than assumed: assemblages from the lower Danian contain short quantitative peaks of opportunistic species that indicate environmental instability, which could be related to the occurrence of blooms of certain primary producers as soon as the light conditions recovered after the impact. This could account for the lack of mass extinctions of benthic foraminifera. Paleoenvironmental changes in the deep sea thus varied geographically, with important differences in the degree and duration of the primary productivity collapse expressed in terms of biomass rather than in terms of diversity. Paleoenvironmental conditions did not recover in the studied sections and cores until, at least, $\sim 300 \mathrm{ky}$ after the K/Pg boundary.
\end{abstract}

Keywords: Benthic foraminifera, Cretaceous, Paleogene, paleoenvironmental changes, impact hypothesis.

\section{RESUMEN}

El límite Cretácico/Paleógeno (K/Pg) marca una de las mayores extinciones en masa del Fanerozoico, tanto en medios marinos como en medios continentales. La mayoría de los científicos acepta que la extinción del límite K/Pg fue al menos en parte originada por el impacto de un meteorito al Norte de la península de Yucatán. El impacto originaría una serie de depósitos anómalos, cuyas características varían en función de la distancia al lugar de impacto; asimismo, provocó una serie de drásticos cambios biológicos, oceánicos y climáticos. Aunque la hipótesis impactista ha sido ampliamente aceptada, se ha generado un intenso debate sobre los mecanismos directos o indirectos mediante los cuales el impacto habría causado las extinciones. Mientras los foraminíferos planctónicos y el nanoplancton calcáreo sufrieron importantes extinciones en masa, los foraminíferos bentónicos 
no experimentaron extinciones masivas en el límite $\mathrm{K} / \mathrm{Pg}$, pero sí muestran cambios temporales en la composición de sus asociaciones. En este trabajo se muestra una síntesis de la evolución de las asociaciones de foraminíferos bentónicos halladas en materiales del tránsito $\mathrm{K} / \mathrm{Pg}$ procedentes de varios cortes y sondeos del área del Golfo de México y Atlántico Noroeste, así como de áreas más distales como el Pacífico Norte, Atlántico Sur y Tethys.

Los cambios experimentados por los foraminíferos bentónicos en el límite $\mathrm{K} / \mathrm{Pg}$ han sido interpretados como resultantes del colapso de la cadena alimenticia pelágica y de la escasez de aporte alimenticio al medio bentónico, como consecuencia de la extinción en masa del plancton calcáreo. No obstante, los cambios en la composición de las asociaciones bentónicas tras el límite $\mathrm{K} / \mathrm{Pg}$ fueron geográficamente variables, y no existe un consenso en cuanto a la interpretación paleoambiental detallada de las asociaciones (condiciones anóxicas o eutróficas en secciones españolas, oligotrofia en perfiles tunecinos, un flujo de nutrientes muy alto e inestable en el Pacífico Norte, etc).

Existen evidencias de que la productividad y la transferencia de alimento al fondo marino se recuperaron más rápido de lo que se asume: las asociaciones del Daniense basal contienen cortos picos cuantitativos de especies oportunistas que indican inestabilidad ambiental, y que podrían estar relacionadas con la proliferación de determinados productores primarios en cuanto se recuperaran las condiciones de luz tras el impacto. Todo ello podría explicar la ausencia de extinción de foraminíferos bentónicos. Así, los cambios paleoambientales en medios profundos variaron geográficamente, con importantes diferencias en el grado y duración del colapso en la productividad primaria expresada en términos de biomasa más que en términos de diversidad. Las condiciones paleoambientales no se recuperaron en los cortes y sondeos estudiados hasta, por lo menos, unos 300 ka tras el límite $\mathrm{K} / \mathrm{Pg}$.

\section{Palabras clave: Foraminíferos bentónicos, Cretácico, Paleógeno, cambios paleoambientales, hipótesis im- pactistas.}

\section{INTRODUCCIÓN}

Durante las últimas décadas, se han estado investigando de forma intensiva cortes y sondeos del Cretácico Superior y Paleógeno inferior distribuidos por todo el mundo, debido a que en el límite Cretácico/Paleógeno (K/Pg) se produjo una de las mayores extinciones en masa de todo el Fanerozoico. Las hipótesis sobre la causa de las extinciones tanto en medios continentales como en medios marinos, sobre el origen de los depósitos característicos del K-Pg y sobre la evolución paleoambiental siguen siendo objeto de debate. La mayoría de los autores aceptan la hipótesis de un impacto meteorítico (Álvarez et al., 1980; Smit \& Hertogen, 1980) en la península de Yucatán (Sureste de México) como la principal causa de las extinciones y de las concentraciones anómalas de iridio, cuarzos de choque y microesférulas en el límite K/Pg (Smit \& Ten Kate, 1982; Hildebrand et al., 1991; Sharpton et al., 1992). Mientras en áreas lejanas al lugar de impacto se observa una capa centimétrica de arcillas con una concentración anómala de iridio, en áreas más próximas (Golfo de México, Caribe y Atlántico Noroeste) se depositó un complejo clástico que ha sido ampliamente aceptado como resultado del impacto, que desestabilizó los márgenes continentales (Bohor, 1996; Smit et al., 1996; Bralower et al., 1998; Soria et al., 2001; Arz et al., 2004). Sin embargo, un reducido grupo de investigadores no apoya la hipótesis impactista, y sugieren que las extinciones no fueron catastróficas sino escalonadas, comenzando en el Maastrichtiense (Keller, 1989 a, b, 2003). Según estos autores, la unidad clástica del K/Pg se depositó como resultado de cambios relativos del nivel del mar o de la tectónica regional (Keller \& Stinnesbeck, 1996; Keller et al., 1997). No obstante, el patrón de extinción gradual y el depósito de los sedimentos del K/Pg a lo largo de un extenso periodo de tiempo resultan de una incorrecta interpretación del registro fósil, y son resultado de discontinuidades, bioturbación, y reelaboración de los fósiles (Signor \& Lipps, 1982; Alegret et al., 2003).

El impacto de un cuerpo extraterrestre en coincidencia con el límite $\mathrm{K} / \mathrm{Pg}$ generó una serie de drásticos cambios biológicos, oceánicos y climáticos (Hsü et al., 1982; Hsü \& McKenzie, 1985; Smit \& Romein, 1985; d'Hondt, 2005) que se han interpretado como causantes de las extinciones. Mientras los foraminíferos planctónicos y el nanoplancton calcáreo sufrieron importantes extinciones en masa (ej., Smit, 1990; Gardin \& Monechi, 1998; Molina et al., 1998; Hollis, 2003) y muestran baja diversidad y abundancia a comienzos del Paleoceno, los foraminíferos bentónicos muestran cambios temporales en la composición de sus asociaciones, extinción de sólo unas pocas especies, y son comunes tras el límite K/Pg (Culver, 2003; Alegret \& Thomas, 2005). Los foraminíferos bentónicos, además de ser unos excelentes marcadores paleobatimétricos, son útiles como marcadores del aporte de nutrientes y de las condiciones de oxigenación en el fondo marino, constituyendo por tanto una importante herramienta para inferir los cambios paleoambientales en el tránsito $\mathrm{K} / \mathrm{Pg}$.

Los cambios temporales en la estructura de las asociaciones de foraminíferos bentónicos de medios profundos han sido interpretados como resultantes del colapso de la cadena alimenticia pelágica y de la escasez de aporte alimenticio al medio bentónico (ej., Kuhnt \& Kaminski, 
1993; Thomas, 1990a, b; Alegret et al., 2001, 2003). No obstante, en algunos cortes el aporte alimenticio aparentemente aumentó tras el límite K/Pg (ej., cortes de Caravaca, Coccioni et al., 1993; y de Agost, en España, Alegret et al., 2003; sondeo DSDP Site 465 en el Pacífico, Alegret \& Thomas, 2005). En algunas de estas localidades (Caravaca, Agost) los sedimentos depositados justo tras el límite K/Pg reflejan condiciones anóxicas (sedimentos laminados), como ocurre en zonas de alta productividad en los océanos actuales. Existen por tanto considerables diferencias regionales en los efectos del evento del $\mathrm{K} / \mathrm{Pg}$ sobre el flujo alimenticio al fondo oceánico.

Resulta difícil comprender cómo los relativamente escasos y reversibles cambios en las asociaciones de foraminíferos bentónicos pudieron ser la respuesta a un colapso de la productividad oceánica, que supuestamente duró cientos de miles de años (Strangelove Ocean; Hsü et al., 1982; Hsü \& Mackenzie, 1985), según se ha deducido de la desaparición del gradiente de los isótopos del carbono bentónico y planctónico (ej. Arthur et al., 1979). Posiblemente, los foraminíferos bentónicos finicretácicos tenían una relación con el medio pelágico menos estrecha que en la actualidad (Thomas et al., 2000), pero deberían de haber sufrido cambios mucho más drásticos si el aporte alimen- ticio hubiera permanecido extremadamente bajo durante cientos de miles de años.

Por otro lado, muchos de los cortes situados en áreas próximas al cráter de impacto están incompletos debido a los procesos de desprendimiento de masas, slumps y deslizamientos submarinos relacionados con la desestabilización de los márgenes continentales ocasionada por el impacto en Chicxulub (Bralower et al., 1998; Klaus et al., 2000; Soria et al., 2001). La comparación de las asociaciones de foraminíferos bentónicos de estos cortes con otros situados en áreas más distales al cráter de impacto proporcionará un registro más completo de la evolución faunística y paleoambiental en el tránsito $\mathrm{K} / \mathrm{Pg}$.

\section{MATERIALES Y MÉTODOS}

Se han estudiado las asociaciones de foraminíferos bentónicos halladas en materiales del tránsito $\mathrm{K} / \mathrm{Pg}$ procedentes de varios cortes y sondeos del área del Golfo de México y Atlántico Noroeste, así como de áreas más distales como el Pacífico Norte, Atlántico Noreste y Sureste, y el Tethys (Fig. 1). Los cortes y sondeos analizados, la síntesis estratigráfica de los sedimentos del tránsito

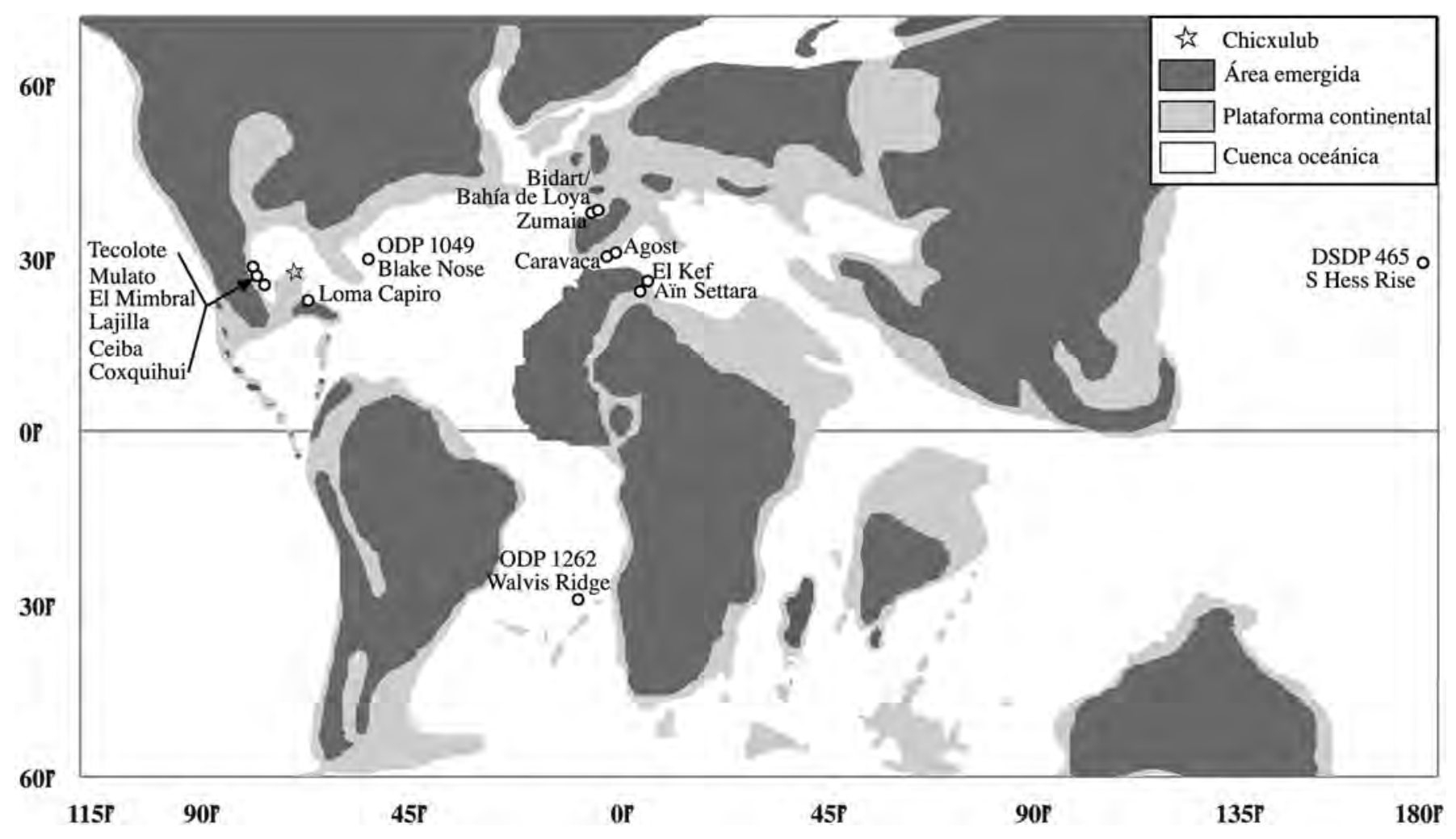

Figura 1. Distribución paleogeográfica de las masas continentales y de las cuencas oceánicas en el límite K/Pg (modificada de Denham \& Scotese, 1987). Se muestra la posición de la estructura de Chicxulub (península de Yucatán, México) y de los cortes y sondeos estudiados.

Paleogeographical distribution of continental masses and oceanic basins at the K/Pg boundary (modified from Denham \& Scotese, 1987). The location of the Chicxulub structure (Yucatán peninsula, México) and the studied sections and cores are shown. 


\begin{tabular}{|c|c|c|c|c|c|c|c|c|c|c|c|c|c|c|c|c|c|c|c|c|c|}
\hline 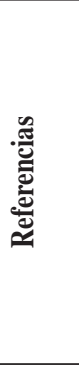 & & 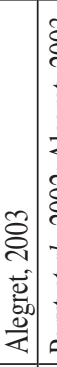 & 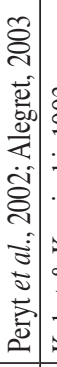 & 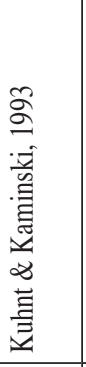 & 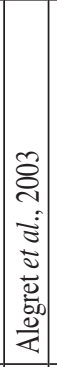 & 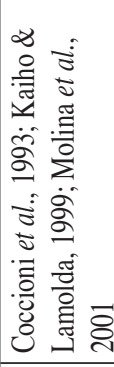 & 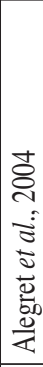 & 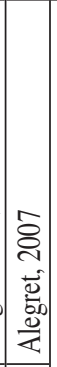 & & 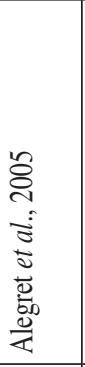 & 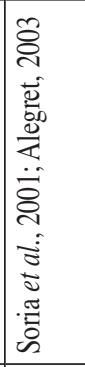 & 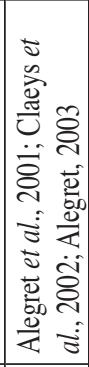 & 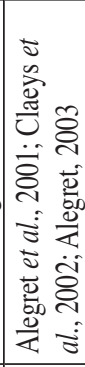 & 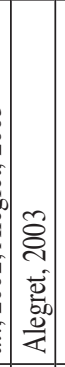 & 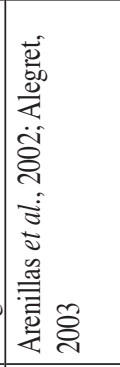 & 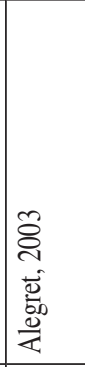 & 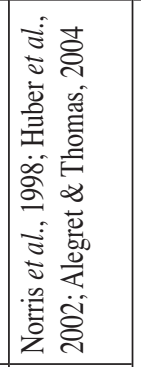 & & 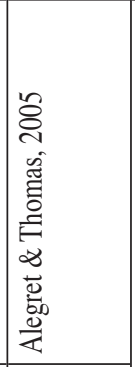 & & 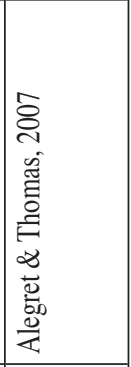 \\
\hline 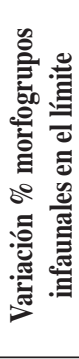 & & 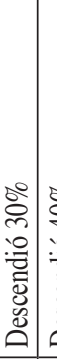 & 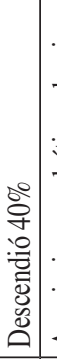 & 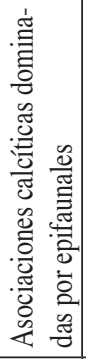 & 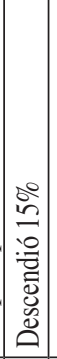 & 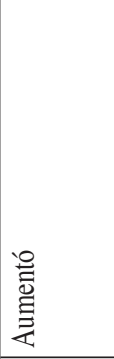 & 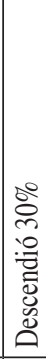 & 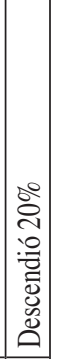 & & 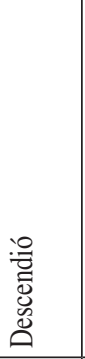 & & 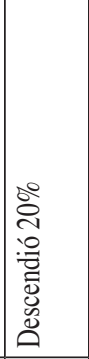 & 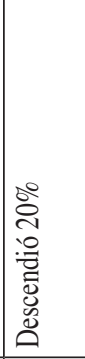 & 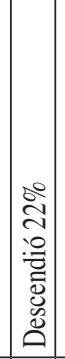 & 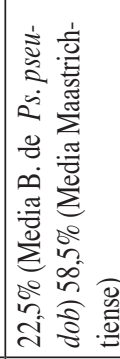 & 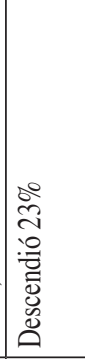 & 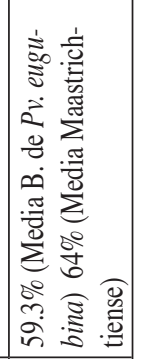 & & 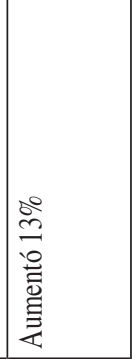 & & 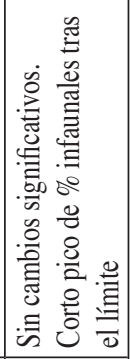 \\
\hline 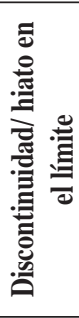 & & $z=$ & \&: & $z$ & z & \& & 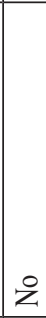 & z & & 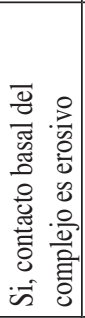 & $\sqrt{\infty}$ & 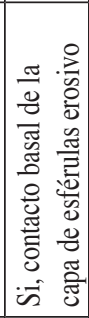 & 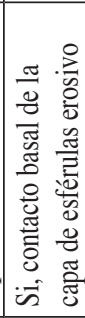 & & 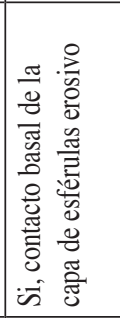 & 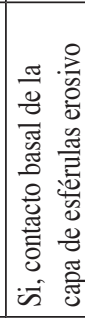 & 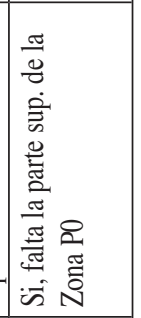 & & 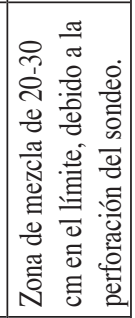 & & z \\
\hline 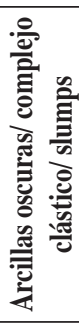 & & 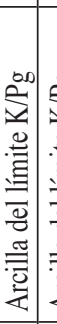 & 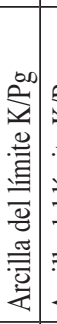 & 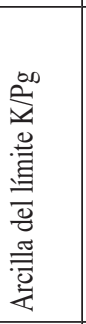 & 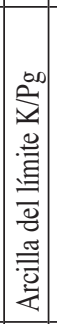 & 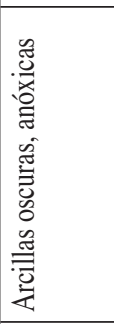 & 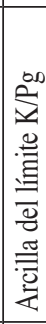 & 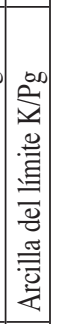 & & 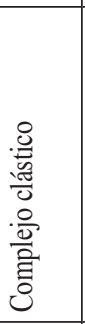 & 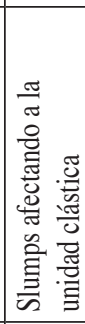 & 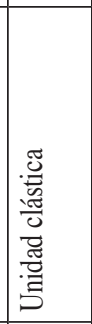 & 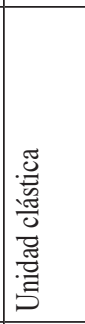 & 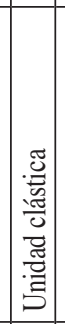 & 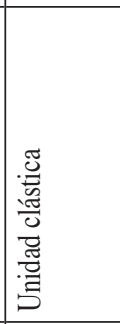 & 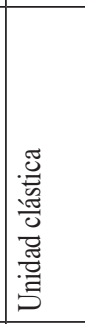 & 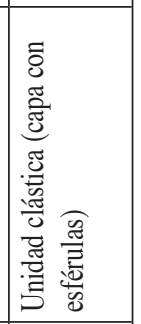 & & 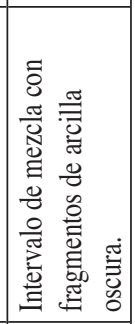 & & 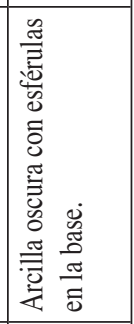 \\
\hline 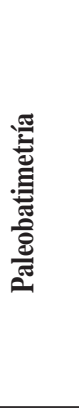 & & 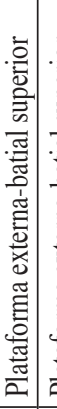 & 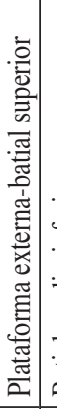 & 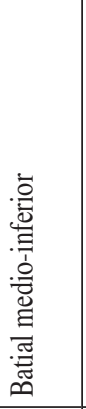 & 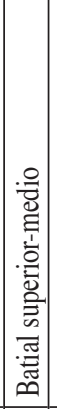 & 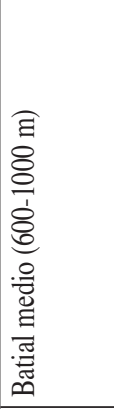 & 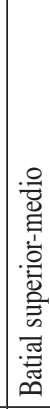 & 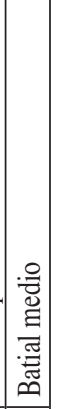 & & 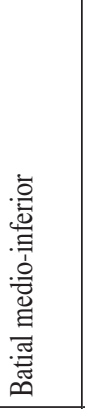 & 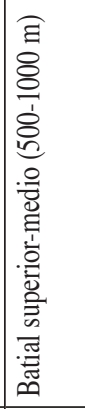 & 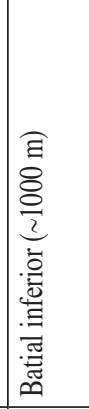 & 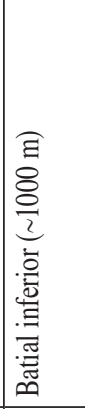 & 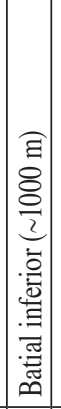 & 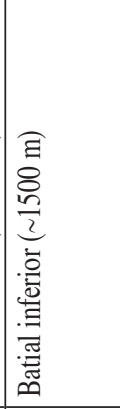 & 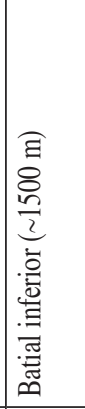 & 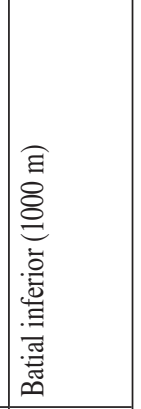 & & 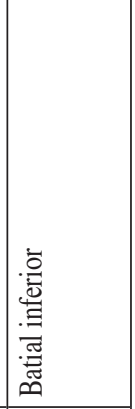 & & 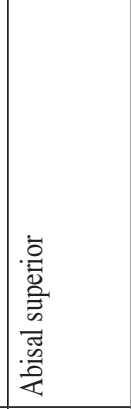 \\
\hline 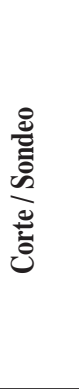 & 窞 & 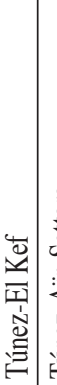 & 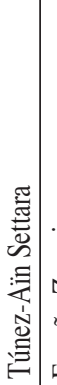 & 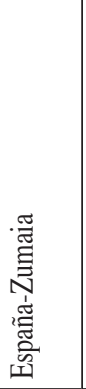 & 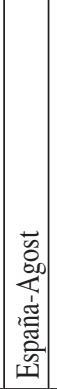 & 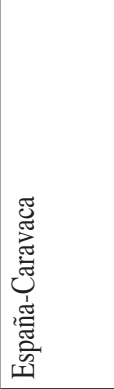 & & 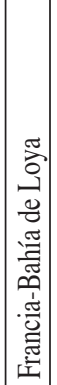 & 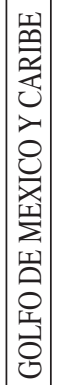 & 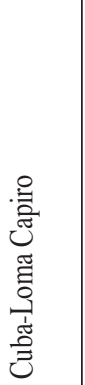 & 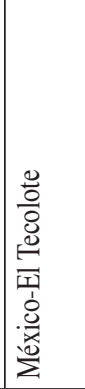 & 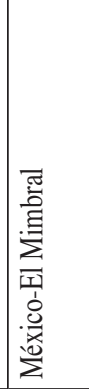 & 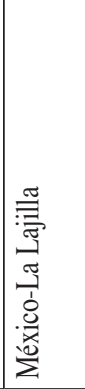 & 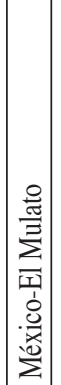 & 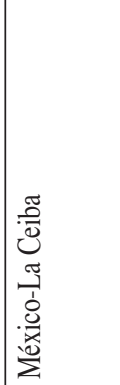 & 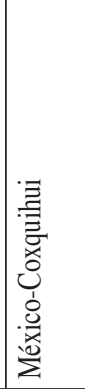 & 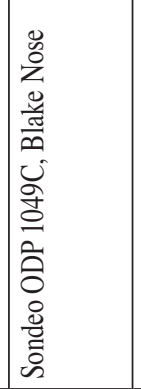 & & 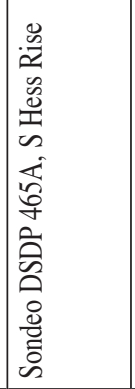 & & 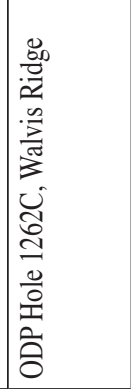 \\
\hline
\end{tabular}

Tabla I. Síntesis estratigráfica de los sedimentos del tránsito K/Pg, paleobatimetrías correspondientes (basadas en el análisis de los foraminíferos bentónicos), y variación en el porcentaje de morfogrupos de foraminíferos bentónicos infaunales en los cortes y sondeos analizados.

Stratigraphic synthesis of K/Pg boundary sediments, paleobathymetry (based on benthic foraminiferal analyses), and changes in the percentages of infaunal benthic foraminiferal morphogroups in the studied sections and cores. 
$\mathrm{K} / \mathrm{Pg}$, y sus paleobatimetrías correspondientes (basadas en el análisis de los foraminíferos bentónicos) se detallan en la Tabla I.

Mientras en áreas lejanas al lugar de impacto, incluido el corte estratotípico de El Kef (Túnez), se observa una capa centimétrica de arcillas con una concentración anómala de iridio (Fig. 2), en áreas más próximas (Golfo de México, Caribe y Atlántico Noroeste) se depositó un complejo clástico cuyo origen se ha relacionado con la desestabilización de los márgenes continentales ocasionada por el impacto meteorítico en Chicxulub (Bralower et al., 1998; Soria et al., 2001). La energía del impacto provocaría enormes olas-tsunami, afectando principalmente a las áreas costeras adyacentes (Golfo de México, Caribe y Atlántico Noroeste; Bourgeois et al., 1988). El resultado sería el depósito de un complejo clástico muy característico con evidencias de impacto, fundamentalmente microtectitas (Smit et al., 1996).

Como consecuencia de los procesos de desprendimiento de masas, slumps y deslizamientos submarinos relacionados con la desestabilización de los márgenes continentales, muchos de los cortes situados en áreas próximas al cráter de impacto están incompletos (Soria et al., 2001; Alegret $\&$ Thomas, 2005). Por este motivo es interesante estudiar cortes y sondeos más alejados del área de impacto, don- de la serie estratigráfica se encuentra más completa; además, en algunas regiones localizadas (ej. Agost y Caravaca en España) se observan arcillas laminadas oscuras con evidencias de anoxia justo en la base del Daniense (Alegret et al., 2003). La comparación de cortes próximos al cráter de impacto con cortes y sondeos situados en áreas más lejanas permitirá obtener un registro más completo de la evolución de los foraminíferos bentónicos y de las condiciones paleoambientales a través del tránsito $\mathrm{K} / \mathrm{Pg}$. Para ello, en el presente trabajo se realiza una síntesis de la evolución de los foraminíferos bentónicos y de las inferencias paleoambientales obtenidas en diversos cortes y sondeos del Golfo de México y Atlántico Noroeste, asî como de áreas más distales como el Pacífico Norte, Atlántico Noreste y Sureste, y el Tethys (Fig. 1). Además, se aportan datos inéditos sobre las asociaciones de foraminíferos bentónicos del corte estratotípico del límite $\mathrm{K} / \mathrm{Pg}$, situado en El Kef (Túnez).

En todos los casos se ha tratado de realizar muestreos de alta resolución. Las muestras fueron disgregadas en agua con $\mathrm{H}_{2} \mathrm{O}_{2}$ y lavadas a través de un tamiz de $63 \mu \mathrm{m}$ para la obtención de los microfósiles. Para realizar los estudios cuantitativos de las asociaciones se separaron unos 300 ejemplares de foraminíferos bentónicos de cada muestra, en la fracción mayor de $63 \mu \mathrm{m}$. Todos los ejemplares fueron montados en celdillas para su conservación e identificación. La clasificación de los foraminíferos a

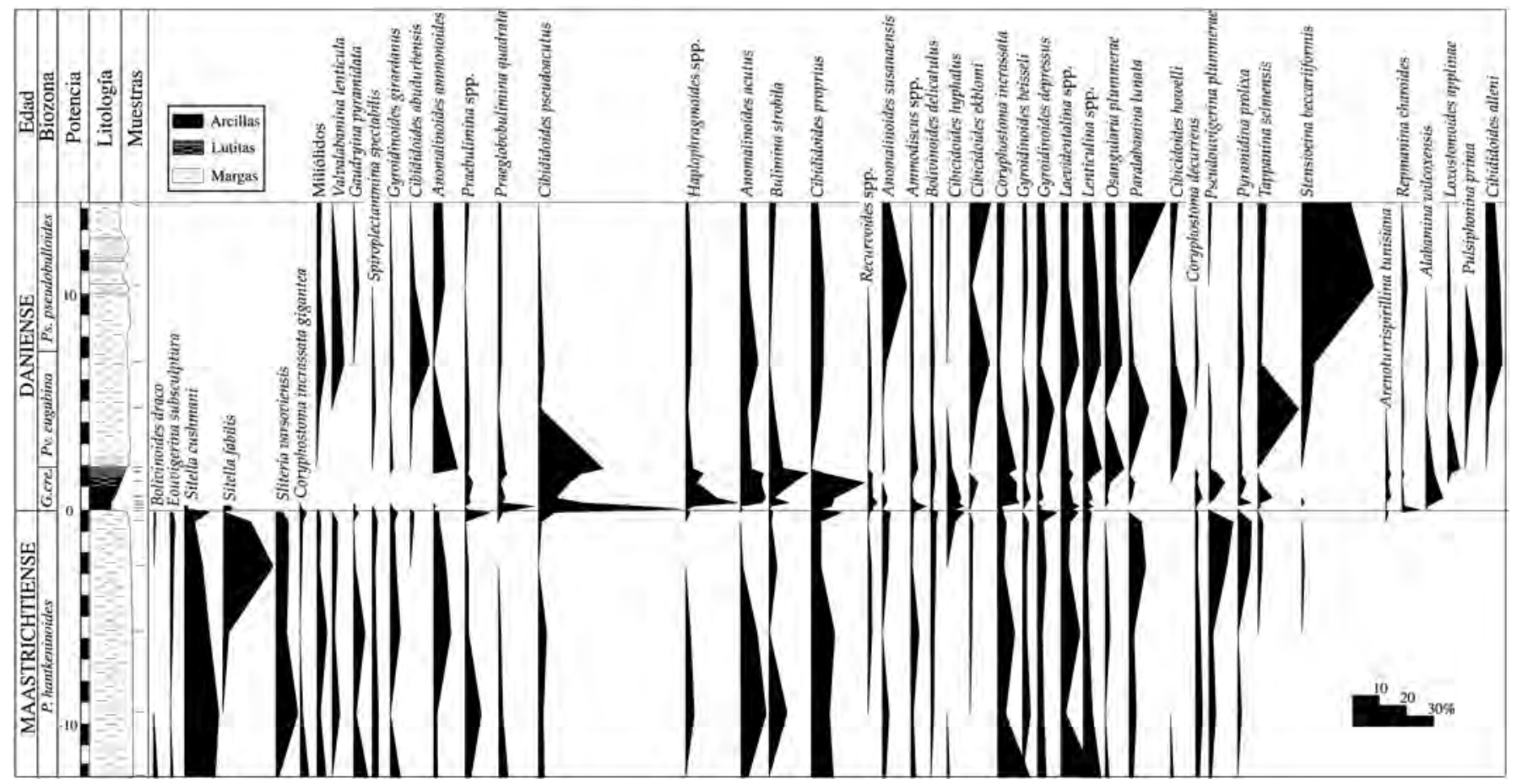

Figura 2. Distribución y abundancia relativa de las especies de foraminíferos bentónicos más características del tránsito K/Pg en el corte estratotípico de El Kef (Túnez). P.= Plummerita; G. cre.= Güembelitria cretacea; Pv.= Parvularugoglobigerina; Ps. = Parasubbotina. Bioestratigrafía de Molina et al. (2006).

Distribution and relative abundance of the most characteristic benthic foraminiferal species across the K/Pg transition at the stratotype section of El Kef (Tunisia). P.= Plummerita; G. cre.= Güembelitria cretacea; Pv.= Parvularugoglobigerina; Ps.= Parasubbotina. Biostratigraphy by Molina et al. (2006). 
nivel genérico sigue los criterios de Loeblich \& Tappan (1987). Cuando fue posible, los foraminíferos bentónicos se identificaron a nivel de especie. En la figura 2 se muestra la abundancia relativa de las especies de foraminíferos bentónicos más características identificadas en el corte de El Kef; en el apéndice I se ha incluido una lista taxonómica con las referencias originales de las especies representadas en la figura 2. Además, se calculó la abundancia relativa de las especies, el índice de diversidad Fisher- $\alpha$ y el de heterogeneidad H(S) Shannon-Weaver (Murray, 1991). En la figura 3 se muestran las variaciones de estos índices en el corte estratotípico del límite $\mathrm{K} / \mathrm{Pg}$ (El Kef), y en las figuras 4 y 5 se muestran fotografías de los taxones más representativos en dicho corte.

Los foraminíferos bentónicos son buenos indicadores en reconstrucciones paleobatimétricas. La comparación entre asociaciones fósiles y actuales, la presencia y abundancia de especies relacionadas con la profundidad, y sus límites superiores (ej., Van Morkhoven et al., 1986; Alegret et al., 2003) han permitido inferir la paleobatimetría. Todos los ejemplares de foraminíferos bentónicos han sido asignados a morfogrupos siguiendo los criterios de Corliss (1985), Jones \& Charnock (1985) y Corliss \& Chen (1988). La comparación de asociaciones fósiles y actuales, y el análisis morfotípico, permiten inferir los microhábitats y los parámetros ambientales como el aporte de nutrientes al fondo marino o la oxigenación en las aguas del fondo (ej., Bernhard, 1986; Jorissen et al., 1995, 2007; Fontanier et al., 2002). No obstante, hay que tener cierta cautela con la interpretación de estas comparaciones, porque no sabemos hasta qué punto las asociaciones del Cretácico y Paleógeno inferior eran análogas a las actuales (ej., Thomas et al., 2000), e incluso en las actuales no se conoce con certeza el microhábitat de muchas especies de medios profundos (ej., Buzas et al., 1993).

\section{RESULTADOS Y DISCUSIÓN}

Las asociaciones de foraminíferos bentónicos del Maastrichtiense superior son diversas en todos los cortes y sondeos estudiados, incluyendo el corte estratotípico (Fig. 3), están dominadas por morfogrupos infaunales (o infaunales y epifaunales), e indican condiciones ambientales estables y mesotróficas. La abundancia relativa de los morfogrupos infaunales se incrementa hacia el Maastrichtiense terminal en los perfiles mexicanos, sugiriendo un mayor flujo en el aporte de nutrientes al fondo marino a finales del Cretácico. Sin embargo, la abundancia de bulimínidos en Blake Nose (50\%) y Hess Rise (hasta 40\%) indica que la productividad en el Atlántico Noroeste y Pacífico Norte fue mayor que en el Golfo de México. Los bulimínidos toleran bajas concentraciones de oxígeno, aunque su abundancia está relacionada fundamentalmente con un abundante flujo alimenticio y con fluctuaciones anuales o estacionales en el aporte al fondo marino (ej., Fontanier et al., 2002; Jorissen et al., 2007). El alto porcentaje de bulimínidos y de

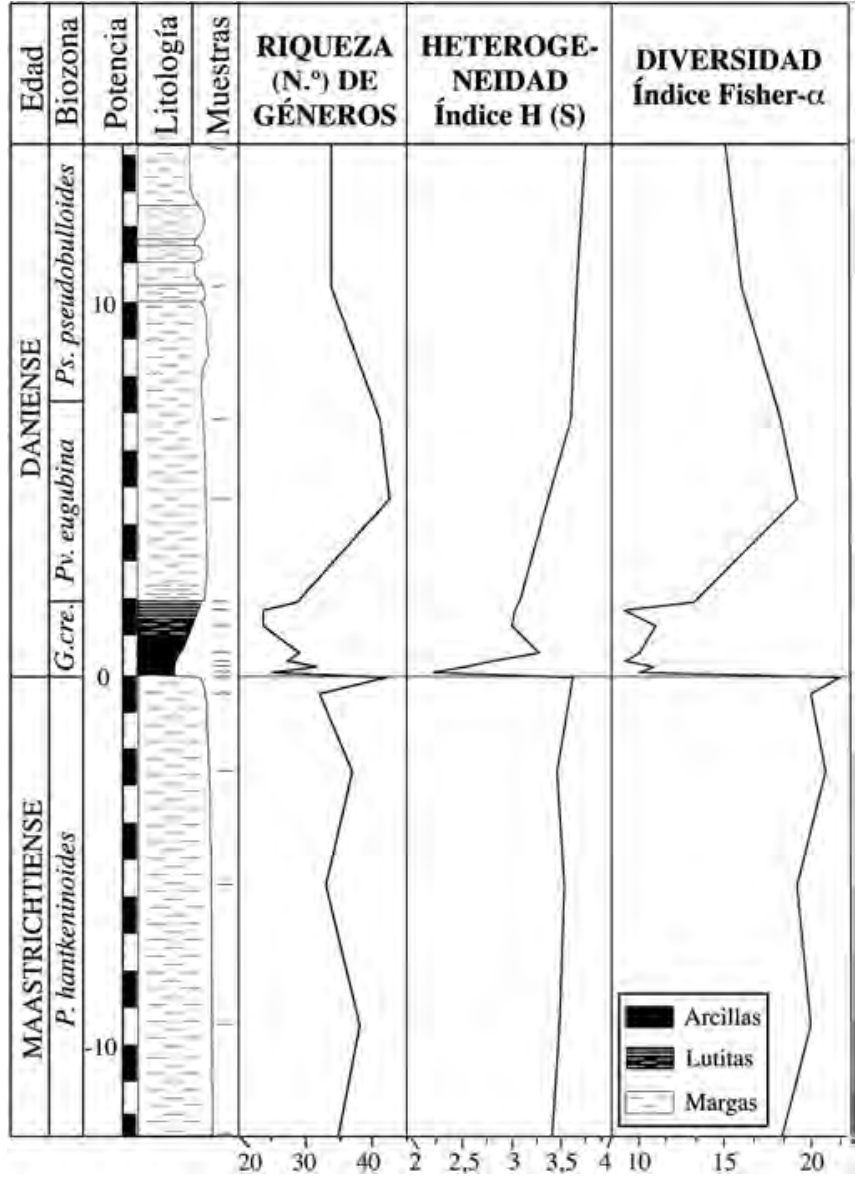

Figura 3. Índices de diversidad, heterogeneidad y riqueza genérica de foraminíferos bentónicos en el corte estratotípico de El Kef (Túnez). P.= Plummerita; G. cre.= Güembelitria cretacea; Pv. = Parvularugoglobigerina; Ps. = Parasubbotina. Bioestratigrafía de Molina et al. (2006).

Diversity, heterogenety and genus richness indices of benthic foraminifera at the stratotype section of $\mathrm{El}$ Kef (Tunisia). P.= Plummerita; G. cre.= Güembelitria cretacea; Pv. $=$ Parvularugoglobigerina; Ps. $=$ Parasubbotina. Biostratigraphy by Molina et al. (2006).

morfogrupos infaunales en Blake Nose, y la escasez de especies típicas de medios batiales oligotróficos, como Stensioeina beccariiformis (White, 1928), Cibicidoides hyphalus (Fisher, 1969), Nuttallides truempyi (Nuttall, 1930) y Gyroidinoides globosus (Hagenow, 1842), sugieren que este sondeo se situaba en un área de corrientes de surgencia (Alegret \& Thomas, 2004). El porcentaje de taxones aglutinados es mayor en los cortes mexicanos (30-62\%) que en el resto de cortes y sondeos, e indica un importante flujo de detritos hacia la cuenca en esta zona.

Los foraminíferos hallados en la capa de esférulas en Blake Nose, y en las unidades clásticas de los perfiles mexicanos y cubanos varían mucho en el tipo de conservación, y las asociaciones consisten en una mezcla de espe- 
cies típicas de medios neríticos y otras de medios batiales (Alegret et al., 2001, 2005). Estas asociaciones debieron ser el resultado del arrastre de sedimentos desde la plataforma y su transporte a lo largo del talud, como consecuencia del impacto del límite $\mathrm{K} / \mathrm{Pg}$. La presencia de componentes neríticos, alóctonos, apoya la hipótesis de que el depósito de estas unidades en la parte media e inferior del talud fue originado por un evento único y geológicamente instantáneo relacionado con extensos desprendimientos de masas y slumps (Alegret et al., 2001, 2005; Soria et al., 2001; Arenillas et al., 2002).

Mientras los foraminíferos planctónicos y el nanoplancton calcáreo fueron afectados por una extinción en masa catastrófica en el límite K/Pg (ej. Arz et al., 2001; Arenillas et al., 2002), las tasas de extinción de los foraminíferos bentónicos no superan el $10 \%$ en ninguno de los cortes estudiados. Más que una extinción en masa, los foraminíferos bentónicos muestran una reorganización de la estructura de sus comunidades, incluyendo la desaparición temporal de taxones Lázaro y un drástico descenso en la diversidad, heterogeneidad y riqueza de géneros (Figs. 2 y 3). En coincidencia con el límite K/Pg se registra un drástico descenso en el porcentaje de los morfogrupos infaunales (25-45\%) en los cortes mexicanos y españoles, asî como en el sondeo de Blake Nose (Atlántico Noroeste). Este descenso, y el descenso en el porcentaje de bulimínidos, sugiere una drástica disminución en el aporte alimenticio al fondo marino, relacionado con la extinción del plancton calcáreo en el límite K/Pg (d'Hondt et al., 1998; Alegret et al., 2001). Una situación similar se observa en los perfiles tunecinos; en el corte de El Kef, el porcentaje de los morfogrupos infaunales descendió un 30\% en coincidencia con el límite K/Pg (Fig. 3). No obstante, esta disminución en el aporte alimenticio fue menos drástica en Blake Nose (Atlántico Noroeste) y en Hess Rise (Pacífico Norte), donde las asociaciones no reflejan condiciones oligotróficas severas, sino un descenso moderado en el aporte alimenticio seguido de una rápida recuperación.

Al contrario de lo que ocurre en la mayoría de los cortes (incluyendo el corte estratotípico de El Kef, Fig. 3) y sondeos, no se observan cambios en la composición de los morfogrupos en el límite K/Pg en el sondeo 1262 de Walvis Ridge (Atlántico Sureste), donde el aumento de los morfotipos infaunales "redondeados planispiralados" y "esféricos" como Pullenia Parker \& Jones, 1862, Globulina d'Orbigny, 1839 o Quadrimorphina Finlay, 1939 compensa la pérdida de morfotipos infaunales "alargados y cilíndricos" (Alegret \& Thomas, 2007). En este sondeo, el drástico descenso en la tasa de acumulación de foraminíferos bentónicos en el límite $\mathrm{K} / \mathrm{Pg}$, y el descenso en el porcentaje de bulimínidos, sugieren una disminución en el aporte alimenticio, pero esto se contradice con la ausencia de cambios en el porcentaje de los morfogrupos infaunales. La abundancia de taxones oportunistas, y las fluctuaciones en la diversidad, heterogeneidad y en la tasa de acumulación de foraminíferos bentónicos, sugieren que tras el límite K/Pg hubo un periodo de fuertes fluctuaciones en el aporte alimenticio.

Aunque algunos autores (Kyte et al., 1980; Kajiwara \& Kaiho, 1992) han sugerido que el fondo del océano pudo ser anóxico tras el límite $\mathrm{K} / \mathrm{Pg}$, únicamente existen evidencias de anoxia local o regional (ej., en la Fish Clay de Dinamarca, Coccioni \& Galeotti, 1998; o en varias localidades del Tethys, Martínez-Ruiz et al., 1992; Coccioni et al., 1993; Kaiho et al., 1999). No obstante, la anoxia o disoxia no se extendió a lo largo de todo el Tethys (Peryt et al., 2002). No se han hallado evidencias de baja oxigenación en los cortes tunecinos (incluyendo el corte estratotípico de El Kef), donde la abundancia de especies con grandes poros en sus conchas como Cibicidoides pseudoacutus (Nakkady, 1950) (Fig. 4d-e) es típica de medios bien oxigenados. Tampoco se observan condiciones de escasa oxigenación en los perfiles mexicanos ni en Blake Nose, aunque un corto episodio de anoxia podría haber desaparecido de su registro sedimentario como resultado de los desprendimientos de masas registrados en esta zona (ej., Klaus et al., 2000; Alegret \& Thomas, 2005).

$\mathrm{La}$ anoxia ha sido relacionada por algunos autores con un exceso de biomasa, resultante de los organismos que murieron en las extinciones (Kyte et al., 1980; Coccioni et al., 1993; Coccioni \& Galeotti, 1998), pero Alegret et al. (2003) discutieron que esta hipótesis es cuantitativamente improbable, dado que la biomasa oceánica en la actualidad supone sólo una pequeña fracción de la biomasa total, y la oxidación de incluso toda la biomasa oceánica no llegaría a consumir suficiente oxígeno como para mantener los oceános anóxicos durante miles de años. Una explicación para la anoxia podría ser la oxidación del metano de los gases hidratados liberados por la desestabilización de los márgenes continentales tras el impacto del $\mathrm{K} / \mathrm{Pg}$ (Alegret et al., 2003).

Al igual que en el corte estratotípico de El Kef, en otros cortes y sondeos del Tethys (ej. Caravaca, Agost, Aïn Settara), del Atlántico Sureste (Walvis Ridge), del Pacífico Norte (Hess Rise), Atlántico Noroeste (Blake Nose) y Atlántico Noreste (Bidart, Bahía de Loya), las asociaciones del Daniense basal contienen cortos picos cuantitativos $(<$ Zona $\mathrm{P} \alpha)$ de especies oportunistas que indican inestabilidad ambiental, concretamente en el aporte alimenticio (Alegret \& Thomas, 2005, 2007; Alegret, 2007). Aun así, queda abierta la pregunta de qué cambios paleoambientales provocaron la aparición de estos picos de especies oportunistas a nivel global. En numerosas localidades, el aporte alimenticio al medio bentónico (según los índices de foraminíferos bentónicos) disminuyó durante varios miles de años tras el límite K/Pg, pero en Hess Rise el aporte alimenticio parece haber aumentado; en algunos cortes del Tethys (ej., Caravaca, Agost) el desarrollo de condiciones de baja oxigenación refleja un incremento aún mayor en el flujo de carbono orgánico. La ausencia de extinciones de 


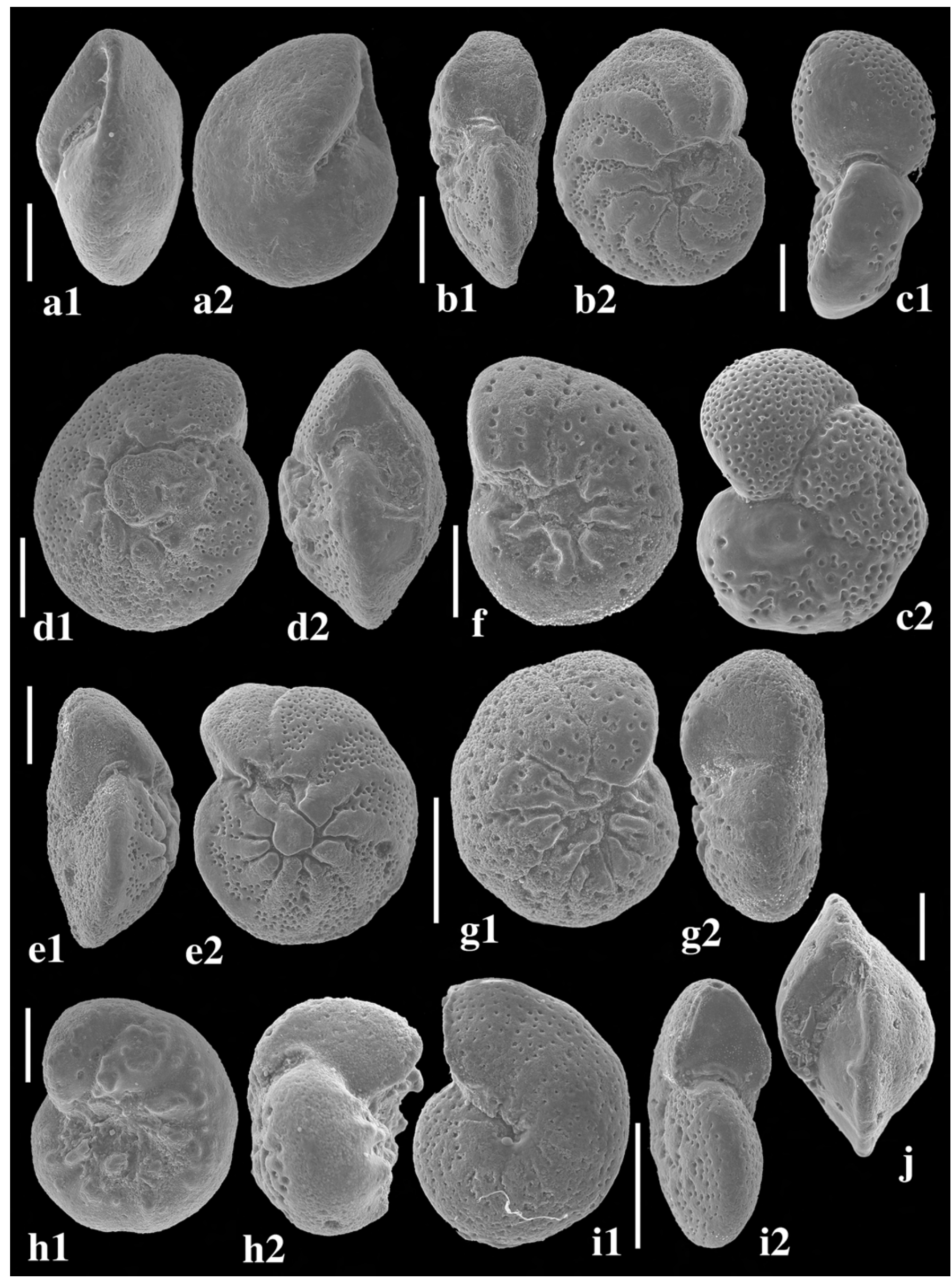


foraminíferos bentónicos en medios profundos indica que no hubo anoxia global tras el límite $\mathrm{K} / \mathrm{Pg}$, y que no sólo el aporte alimenticio se recuperó más rápido de lo sugerido (modelo Strangelove Ocean; Hsü \& McKenzie, 1985), sino que también su transporte al fondo marino se recuperó más rápido que los resultados obtenidos en el modelo del "Océano vivo" propuesto por Coxall et al. (2006).

La biomasa de los productores primarios en los océanos y el flujo de materia orgánica al fondo debieron de recuperarse más rápido que la diversidad de la biota planctónica, a través de la proliferación masiva de taxones oportunistas restringidos a regiones determinadas, tal y como muestra la distribución geográficamente limitada de arcillas negras laminadas. Estos cortos picos de fitoplancton generaron un aporte de alimento al fondo oceánico muy variable en calidad y cantidad, provocando estrés medioambiental en las asociaciones bentónicas. Dicho estrés pudo deberse a un alto aporte alimenticio por parte de productores primarios que serían difíciles de digerir por los foraminíferos bentónicos, como diversas especies de dinoflagelados (Alegret et al., 2003; Alegret \& Thomas, 2004). Así, los cambios paleoambientales en medios profundos variaron geográficamente, con importantes diferencias en el grado y duración del colapso en la productividad primaria expresada en términos de biomasa más que en términos de diversidad. Las condiciones paleoambientales no se recuperaron en los cortes y sondeos estudiados hasta, por lo menos, la segunda mitad de la Biozona de Parasubbotina pseudobulloides (unos 300.000 años tras el límite K/Pg).

El registro de los isótopos del carbono en conchas de foraminíferos bentónicos y en la fracción carbonatada fina reflejan un rápido colapso de los valores superficiales hasta igualar los valores de las aguas profundas en el límite $\mathrm{K} / \mathrm{Pg}$ debido a un descenso en los valores del sedimento y un incremento en los valores bentónicos. Este registro concuerda con la señal esperada durante un corto colapso de la productividad primaria en el límite $\mathrm{K} / \mathrm{Pg}$. Sin embargo, en algunos sondeos como el Sondeo 1262 de Walvis Ridge (Atlántico Sureste), tras el colapso del límite $\mathrm{K} / \mathrm{Pg}$ se observa un gradiente inverso, con valores muy negativos en los isótopos del sedimento, que muestran un pico unos 200.000 años tras el límite $\mathrm{K} / \mathrm{Pg}$ (Thomas et al., 2007). Una posible explicación del gradiente inverso en los isótopos del carbono sería la presencia de corrientes de surgencia locales o regionales, que en los océanos actuales confieren a los foraminíferos planctónicos valores de los isótopos de carbono más negativos que los que presentan los foraminíferos bentónicos (Smart \& Thomas, 2006). En Walvis Ridge, la alta tasa de acumulación de foraminíferos bentónicos tras el límite $\mathrm{K} / \mathrm{Pg}$ indica un elevado aporte alimenticio al fondo oceánico. Sin embargo, en las mismas muestras se registran valores mínimos de $\delta^{13} \mathrm{C}$ en el sedimento y bajos íncides de diversidad, lo que sugiere que se trataba además de un medio de gran estrés y amplias fluctuaciones ambientales con alteraciones en la estratificación oceánica.

Si la productividad y la transferencia de alimento al fondo marino se recuperaron más rápido de lo asumido hasta el momento, se podría explicar la ausencia de una extinción masiva en los foraminíferos bentónicos. En ese caso, no obstante, se ha de encontrar una explicación para la persistente ausencia de los gradientes de los isótopos de carbono bentónicos-planctónicos. Son necesarios más análisis del $\delta^{13} \mathrm{C}$ en el bentos y en el plancton para explicar por qué estos valores confluyen, e incluso los valores superficiales se llegan a hacer más ligeros que los bentónicos (gradiente inverso) en numerosas localidades, lo que supone la adición de isótopos ligeros del carbono al sistema océano-atmósfera durante largos periodos de tiempo ( $10^{5}$ años). Para concluir, no existe actualmente una explicación de los registros de los isótopos del carbono a través del límite $\mathrm{K} / \mathrm{Pg}$. Es necesario realizar análisis de mayor resolución para documentar si el gradiente negativo se produjo a nivel global (reflejando por tanto el ciclo de carbono global) o a nivel local o regional (reflejando la productividad o el transporte de materia orgánica), o si fue aleatorio (reflejando efectos de la diagénesis). El estudio detallado de las asociaciones de foraminíferos bentónicos puede aportar información sobre los cambios en los medios oceánicos y en el ciclo del carbono oceánico durante el límite $\mathrm{K} / \mathrm{Pg}$.

Figura 4. Fotografías de microscopio electrónico de barrido de los foraminíferos bentónicos más característicos hallados en el corte estratotípico de El Kef (Túnez). a1-2, Alabamina wilcoxensis Toulmin, 1941 (muestra Kef 12,7). b1-2, Anomalinoides susanaensis (Browning in Mallory, 1959) (muestra Kef 21,95). c1-2, Anomalinoides rubiginosus (Cushman, 1926) (muestra Kef 21,95). d1-2, Cibicidoides pseudoacutus (Nakkady, 1950) (muestra Kef 12,7). e1-2, Cibicidoides pseudoacutus (Nakkady, 1950) (muestra Kef 21,95). f, g1-2, Stensioeina beccariiformis (White, 1928) (muestra Kef 21,95). h1-2, Sliteria varsoviensis Gawor-Biedowa, 1992 (muestra Kef 3). i1-2, Anomalinoides ammonoides (Reuss, 1844) (muestra Kef 21,95). j, Oridorsalis plummerae (Cushman, 1948) (muestra Kef 21,95). Las escalas equivalen a 100 micras.

Scanning electron-microscope photographs of the most characteristic benthic foraminifera from the stratotype section of El Kef(Tunisia). a1-2, Alabamina wilcoxensis Toulmin, 1941 (sample Kef 12,7). b1-2, Anomalinoides susanaensis (Browning in Mallory, 1959) (sample Kef 21,95). c1-2, Anomalinoides rubiginosus (Cushman, 1926) (sample Kef 21,95). d1-2, Cibicidoides pseudoacutus (Nakkady, 1950) (sample Kef 12,7). e1-2, Cibicidoides pseudoacutus (Nakkady, 1950) (sample Kef 21,95). f, g1-2, Stensioeina beccariiformis (White, 1928) (sample Kef 21,95). h1-2, Sliteria varsoviensis Gawor-Biedowa, 1992 (sample Kef 3). il-2, Anomalinoides ammonoides (Reuss, 1844) (sample Kef 21,95). j, Oridorsalis plummerae (Cushman, 1948) (sample Kef 21,95). Scale bars: 100 microns. 


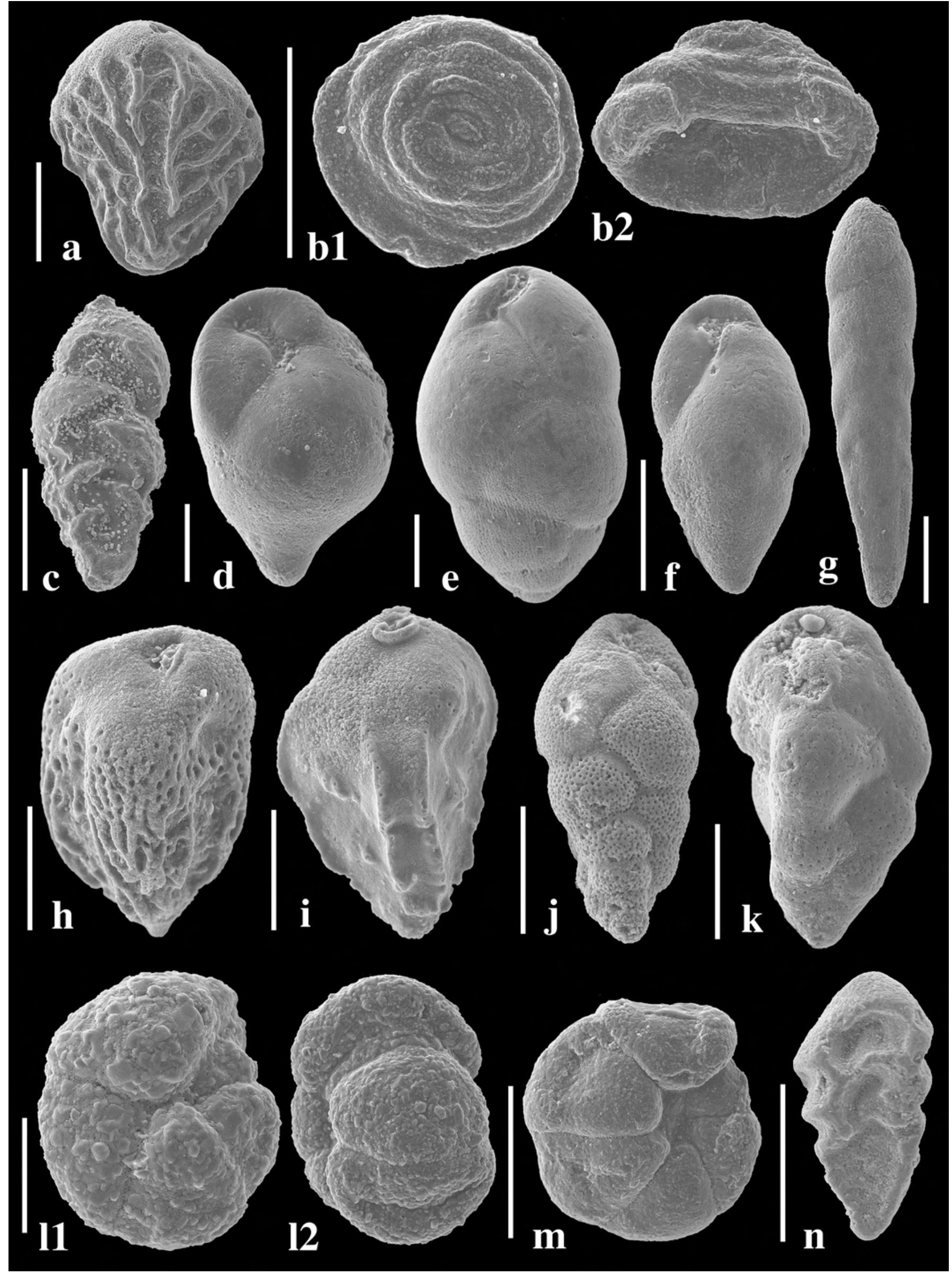




\section{CONCLUSIONES}

Mientras los foraminíferos planctónicos y el nanoplancton calcáreo sufrieron importantes extinciones en masa durante el límite $\mathrm{K} / \mathrm{Pg}$, los foraminíferos bentónicos no experimentaron extinciones significativas, pero sí muestran cambios temporales en la composición de sus asociaciones. Los cambios experimentados por los foraminíferos bentónicos en el límite K/Pg han sido interpretados como resultantes del colapso de la cadena alimenticia pelágica y de la escasez de aporte alimenticio al medio bentónico, como consecuencia de la extinción en masa del plancton calcáreo. Sin embargo, los cambios en la composición de las asociaciones bentónicas tras el límite K/Pg fueron geográficamente variables, y no existe un consenso en cuanto a la interpretación paleoambiental detallada de las asociaciones.

Existen evidencias de que la productividad y la transferencia de alimento al fondo marino se recuperaron más rápido de lo que se asume, a través de la proliferación de determinadas especies de fitoplancton limitadas a regiones determinadas, que generaron un aporte de alimento al fondo oceánico muy variable en calidad y cantidad, provocando estrés medioambiental en las asociaciones bentónicas. Dicho estrés pudo deberse a un elevado aporte alimenticio por parte de productores primarios que serían difíciles de digerir por los foraminíferos bentónicos, como diversas especies de dinoflagelados. Como resultado, las asociaciones del Daniense basal contienen picos cuantitativos de especies de foraminíferos bentónicos oportunistas que indican inestabilidad ambiental.

El desarrollo de un gradiente inverso en los isótopos del carbono bentónicos-planctónicos en algunos sondeos, como en Walvis Ridge, podría deberse a la presencia de corrientes de surgencia locales o regionales. El gradiente inverso desapareció gradualmente, y las condiciones paleoambientales no se recuperaron en los cortes y sondeos estudiados hasta, por lo menos, la segunda mitad de la Biozona de Parasubbotina pseudobulloides ( $300 \mathrm{ka}$ tras el límite $\mathrm{K} / \mathrm{Pg})$.

\section{AGRADECIMIENTOS}

Agradezco las acertadas sugerencias y la labor de edición realizadas por los revisores Alejandro Cearreta y Juan Usera, y por el editor de la revista Rodolfo Gozalo. Asimismo agradezco la inestimable ayuda de mis colegas Ignacio Arenillas, José Antonio Arz y Eustoquio Molina, quienes proporcionaron el marco bioestratigáfico y colaboraron en la recogida de algunas de las muestras. Estre trabajo ha sido financiado por el Ministerio de Ciencia y Tecnología (contrato Ramón y Cajal concedido a la autora, y proyecto Consolider CGL 2007-63724).

\section{REFERENCIAS}

Alegret, L. 2003. Sedimentología y Micropaleontología (foraminíferos bentónicos) del tránsito Cretácico-Terciario: correlación entre las áreas del Golfo de México y del Tethys. Tesis Doctoral. Bell Howell Ed., Madrid, $476 \mathrm{pp}$.

Alegret, L. 2007. Recovery of the deep-sea floor after the Cretaceous/Paleogene boundary event: the benthic foraminiferal record in the Basque-Cantabrian basin and in SE Spain. Palaeogeography, Palaeoclimatology, Palaeoecology, 255, 181-194.

Alegret, L. \& Thomas, E. 2001. Upper Cretaceous and lower Paleogene benthic Foraminifera from northeastern Mexico. Micropaleontology, 47, 269-316.

Alegret, L. \& Thomas, E. 2004. Benthic foraminifera and environmental turnover across the Cretaceous/Paleogene boundary at Blake Nose (ODP Hole 1049C, Northwestern Atlantic). Palaeogeography, Palaeoclimatology, Palaeoecology, 208, 59-83.

Alegret, L. \& Thomas, E. 2005. Paleoenvironments across the Cretaceous/Tertiary boundary in the central North Pacific (DSDP Site 465), the Gulf of Mexico and the Tethys: the benthic foraminiferal record. Palaeogeography, Palaeoclimatology, Palaeoecology, 224, 53-82.

Alegret, L. \& Thomas, E. 2007. Deep-Sea environments across the Cretaceous/Paleogene boundary in the eastern

Figura 5. Fotografías de microscopio electrónico de barrido de los foraminíferos bentónicos más característicos hallados en el corte estratotípico de El Kef (Túnez). a, Bolivinoides draco (Marsson, 1878) (muestra Kef 11,30). b1-2, Arenoturrispirillina tunisiana Peryt et al., 2004 (muestra Kef 12,7). c, Eouvigerina subsculptura McNeil \& Caldwell, 1981 (muestra Kef 6,60). d, Sitella cushmani (Sandidge, 1932) (muestra Kef 0). e, Praeglobobulimina quadrata (Plummer, 1926) (muestra Kef 12,10). f, Sitella fabilis (Cushman \& Parker, 1936) (muestra Kef 9,5). g, Coryphostoma incrassata (Reuss, 1851) (muestra Kef 0). h, Bulimina strobila Marie, 1941 (muestra Kef 9,5). i, Pseudouvigerina plummerae Cushman, 1927 (muestra Kef 9,5). j, Pyramidina prolixa (Cushman \& Parker, 1935) (muestra Kef 9,5). k, Pyramidina cf. prolixa (muestra Kef 9,5). 11-2, m, Haplophragmoides sp. (muestra Kef 12,7). n, Tappanina selmensis (Cushman, 1933) (muestra Kef 16,50). Las escalas equivalen a 100 micras.

Scanning electron-microscope photographs of the most characteristic benthic foraminifera from the stratotype section of El Kef (Tunisia). a, Bolivinoides draco (Marsson, 1878) (sample Kef 11,30). b1-2, Arenoturrispirillina tunisiana Peryt et al., 2004 (sample Kef 12,7). c, Eouvigerina subsculptura McNeil \& Caldwell, 1981 (sample Kef 6,60). d, Sitella cushmani (Sandidge, 1932) (sample Kef 0). e, Praeglobobulimina quadrata (Plummer, 1926) (sample Kef 12,10). f, Sitella fabilis (Cushman \& Parker, 1936) (sample Kef 9,5). g, Coryphostoma incrassata (Reuss, 1851) (sample Kef 0). h, Bulimina strobila Marie, 1941 (sample Kef 9,5). i, Pseudouvigerina plummerae Cushman, 1927 (sample Kef 9,5). j, Pyramidina prolixa (Cushman \& Parker, 1935) (sample Kef 9,5). $\boldsymbol{k}$, Pyramidina $c f$. prolixa (sample Kef 9,5). l1-2, $\boldsymbol{m}$, Haplophragmoides $s p$. (sample Kef 12,7). n, Tappanina selmensis (Cushman, 1933) (sample Kef 16,50). Scale bars: 100 microns. 
South Atlantic Ocean (ODP Leg 208, Walvis Ridge). Marine Micropaleontology, 64, 1-17.

Alegret, L., Molina, E. \& Thomas, E. 2001. Benthic foraminifera at the Cretaceous/Tertiary boundary around the Gulf of Mexico. Geology, 29, 891-894.

Alegret, L., Molina, E. \& Thomas, E., 2003. Benthic foraminiferal faunal turnover across the Cretaceous/Tertiary Boundary at Agost (Southeastern Spain). Marine Micropaleontology, 48, 251-279.

Alegret, L., Kaminski, M. A. \& Molina, E. 2004. Paleoenvironmental recovery after the Cretaceous/Tertiary boundary crisis: evidence from the marine Bidart section (SW France). Palaios, 19, 574-586.

Alegret, L., Arenillas, I., Arz, J. A., Diaz, C., Grajales-Nishimura, J. M., Mélendez, A., Molina, E., Rojas, R. \& Soria, A. R. 2005. Cretaceous-Paleogene boundary deposits at Loma Capiro, Cuba: evidence for the Chicxulub impact. Geology, 33, 721-724.

Alth, A. 1850. Geognostisch-paläontologische Beschreibung der nächsten Umgebung von Lemberg. Haidinger's naturwisschen Abhandlungen, Viena, 3, 171-284.

Álvarez, L. W., Álvarez, W., Asaro, F. \& Michel, H. V. 1980. Extraterrestrial cause for the Cretaceous-Tertiary extinction. Science, 208, 1195-1108.

Arenillas, I., Alegret, L., Arz, J. A., Liesa, C., Meléndez, A., Molina, E., Soria, A. R., Cedillo, E., Grajales, J. M. \& Rosales, C. 2002. Cretaceous-Tertiary boundary planktic foraminiferal mass extinction and biochronology at $\mathrm{La}$ Ceiba and Bochil, Mexico, and El Kef, Tunisia. In: Catastrophic events and mass extinctions: impacts and beyond (eds. C. Koeberl \& K. G. MacLeod). Geological Society of America Special Paper, 356, 253-264.

Arthur, M. A., Scholle, P. \& Hasson, P. 1979. Stable isotopes of oxygen and carbon in carbonates from Sites 398 and 116 of the Deep Sea Drilling Project. Initial Reports DSDP , 47, 477-492.

Arz, J. A., Alegret, L., Arenillas, I., Liesa, C., Molina, E. \& Soria, A. R. 2001. Extinción de foraminíferos en el límite Cretácico/Terciario de Coxquihui (México) y su relación con las evidencias de impacto. Revista Española de Micropaleontología, 33, 221-236.

Arz, J. A., Alegret, L. \& Arenillas, I. 2004. Foraminiferal biostratigraphy and paleoenvironmental reconstruction at Yaxcopoil-1 drill hole (Chicxulub crater, Yucatan Peninsula). Meteoritics \& Planetary Science, 39, 1099-1111.

Bernhard, J. M. 1986. Characteristic assemblages and morphologies of benthic foraminifera from anoxic, organicrich deposits: Jurassic through Holocene. Journal of Foraminiferal Research, 16, 207-215.

Bohor, B. F. 1996. A sediment gravity flow hypothesis for siliciclastic units at the K/T boundary, northeastern Mexico. Geological Society of America Special Paper, 307, 183-196.

Bourgeois J., Hansen T. A., Wiberg P. L. \& Kauffman E. G. 1988. A tsunami deposit at the Cretaceous-Tertiary boundary in Texas. Science, 241, 567-570.

Bralower, T. J., Paull, C. K. \& Leckie, R. M. 1998. The Cretaceous/Tertiary boundary cocktail: Chicxulub impact triggers marine collapse and extensive sediment gravity flows. Geology, 26, 331-334.

Brotzen, F. 1940. Flintrännans och Trindelrännans geologi (Öresund). Sveriges Geologiska Undersökning, C435, 34, 3-33

Brotzen, F. 1948. The Swedish Paleocene and its foraminiferal fauna. Sveriges Geologiska Undersökning, C493, 42, 1-140.

Buzas, M. A., Culver, S. J. \& Jorissen, F. J. 1993. A statistical evaluation of the microhabitats of living (stained) infaunal benthic foraminifera. Marine Micropaleontology, 29, 73-76.

Claeys, Ph., Kiessling, W. \& Alvarez, W. 2002. Distribution of Chicxulub ejecta at the Cretaceous-Tertiary boundary. In: Catastrophic Events and Mass Extinctions: Impacts and Beyond (eds. C. Koeberl \& K. G. MacLeod). Geological Society of America Special Paper, 356, 55-68.

Coccioni, R. \& Galeotti, S. 1998. What happened to small benthic foraminifera at the Cretaceous/ Tertiary boundary? Bulletin de la Société Géologique de France, 169, 271-279.

Coccioni, R., Fabbrucci, L. \& Galeotti, S. 1993. Terminal Cretaceous deep-water benthic foraminiferal decimation, survivorship and recovery at Caravaca (SE Spain). $P a$ laeopelagos, 3, 3-24.

Corliss, B. H. 1985. Microhabitats of benthic foraminifera within deep-sea sediments. Nature, 314, 435-438.

Corliss, B. H. \& Chen, C. 1988. Morphotype patterns of Norwegian Sea deep-sea benthic foraminifera and ecological implications. Geology, 16, 716-719.

Coxall, H. K., D'Hondt, S. \& Zachos, J. C. 2006. Pelagic evolution and environmental recovery after the CretaceousPaleogene mass extinction. Geology, 34, 297-300.

Cushman, J. A. 1926. The foraminifera of the Velasco Shale of the Tampico embayment. American Association of Petroleum Geologists Bulletin, 10, 581-612.

Cushman, J. A. 1927. New and interesting foraminifera from Mexico and Texas. Contributions of the Cushman Laboratory for Foraminiferal Research, 3, 111-117.

Cushman, J. A. 1933. Foraminifera: their classification and economic use. Cushman Laboratory for Foraminiferal Research, Special Publication, 4, 1-349.

Cushman, J. A. 1948. Additional new foraminifera from the American Paleocene. Contributions of the Cushman Laboratory for Foraminiferal Research, 24, 43-45.

Cushman, J. A. \& Parker, F. L. 1935. Some American Cretaceous Buliminas. Contributions of the Cushman Laboratory for Foraminiferal Research, 11, 96-101.

Cushman, J. A. \& Parker, F. L. 1936. Some American Eocene Buliminas. Contributions of the Cushman Laboratory for Foraminiferal Research, 12, 39-45.

Culver, S. J. 2003. Benthic foraminifera across the Cretaceous-Tertiary (K-T) boundary: a review. Marine Micropaleontology, 47, 177-226.

Denham, C. R. \& Scotese, C. R. 1987. Terra Mobilis: a plate tectonic program for the Macintosh, versión 1.1. Geotimes, 26, Earth in Motion Technology, Austin, TX.

d'Hondt, S. 2005. Consequences of the Cretaceous/Paleogene 
mass extinction for marine ecosystems. Annual Review of Ecology, Evolution, and Systematics, 36, 295-317.

d'Hondt, S., Donaghay, P., Zachos, J. C., Luttenberg, D. \& Lindinger, M. 1998. Organic carbon fluxes and ecological recovery from the Cretaceous-Tertiary mass extinction. Science, 282, 276-279.

d'Orbigny, A. 1839. Voyage dans l'Amerique Méridionale; Foraminifères. P. Bertrand, Strasbourg, 5, 60.

Ehrenberg, C. G. 1854. Mikrogeologie. Leipzig, 22 pp.

Finlay, H. J. 1939. New Zealand foraminifera; key species in stratigraphy. Royal Society of New Zealand, 69, 325.

Fisher, M. J. 1969. Benthonic foraminifera from the Maestrichtian Chalk of Galicia Bank, West of Spain. Palaeontology, 12, 189-200.

Fontanier, C., Jorissen, F. J., Licari, L., Alexandre, A., Anschutz, P. \& Carbonel, P. 2002. Live benthic foraminiferal faunas from the Bay of Biscay: faunal density, composition and microhabitats. Deep-Sea Research I, 49, 751-785.

Gardin, S. \& Monechi, S. 1998. Palaeoecological change in middle to low latitude calcareous nannoplankton at the Cretaceous/Tertiary boundary. Bulletin de la Société Géologique de France, 169, 709-723.

Gawor-Biedowa, E. 1992. Campanian and Maastrichtian Foraminifera from the Lublin Upland, Eastern Poland. Palaeontologica Polonica, 52, 1-187.

Grzybowski, J. 1898. Otwornice pokladów naftonosnych okolicy Krosna. Rozprawy Akademii Umiejetnosci w Krakowie, Wydziat Matematyczno-Przyrodniczy, Kraków, 33, 257-305.

Hagenow, F. von. 1842. Monographie der Rügen'schen Kreide-Versteinerungen; Abtheilung III- Mollusken. Neues Jahrbuch für Mineralogie, Geognosie, Geologie und Petrefakten-Kunde, 528-575.

Hildebrand, A. R., Penfield, G. T., Kring, D. A., Pilkington, M., Camargo, A. Z., Jacobsen, S. B. \& Boynton, W. V. 1991. Chicxulub Crater: a possible Cretaceous/Tertiary boundary impact crater on the Yucatan Peninsula, Mexico. Geology, 19, 867-871.

Hollis, C. J. 2003. The Cretaceous/Tertiary boundary event in New Zealand: profiling mass extinction. New Zealand Journal of Geology and Geophysics, 46, 307-321.

Hsü, K. J. \& McKenzie, J. A. 1985. A “strangelove” ocean in the earliest Tertiary. In: Geophysical Monographs 32: The Carbon Cycle and Atmospheric $\mathrm{CO}_{2}$; Natural Variations Archean to Present (eds. E. T. Sundquist \& W. S. Broecker). AGU, Washington D.C., 487-492.

Hsü, K. J., He, Q., McKenzie, J., Weissert, H., Perch-Nielsen, K., Oberhaensli, H., Kelts, K., LaBrecque, J., Tauxe, L., Kraehenbuehl, U., Percival, S. F., Wright, R., Karpoff, A. M., Petersen, N., Tucker, P., Poore, R. Z., Gombos, A., Pisciotto, K., Carman, M. F. Jr. \& Schreiber, E. 1982. Mass mortality and its environmental and evolutionary consequences. Science, 216, 249-256.

Huber, B. T., MacLeod, K. G. \& Norris, R. D. 2002. Abrupt extinction and subsequent reworking of Cretaceous planktonic foraminifera across the Cretaceous-Tertiary boundary: Evidence from the subtropical North Atlantic.
In: Catastrophic Events and Mass Extinctions: Impacts and Beyond (eds. C. Koeberl \& K. G. MacLeod). Geological Society of America Special Paper, 356, 227-289.

Jones, R. W. \& Charnock, M. A. 1985. "Morphogroups" of agglutinated foraminifera. Their life positions and feeding habits and potential applicability in (Paleo)Ecological studies. Revue de Palèobiologie, 4, 311-320.

Jones, T. R. \& Parker, W. K. 1860. On the rhizopodal fauna of the Mediterranean compared with that of the Italian and some Tertiary deposits. Quaterly Journal of the Geological Society of London, 16, 292-307.

Jorissen, F. J., Stigter, H. C. \& Widmark, J. G. V. 1995. A conceptual model explaining benthic foraminiferal microhabitats. Marine Micropaleontology, 26, 3-15.

Jorissen, F. J., Fontanier, C. \& Thomas, E. 2007. Paleoceanographical proxies based on deep-sea benthic foraminiferal assemblage characteristics. In: Proxies in Late Cenozoic Paleoceanography (Pt. 2): Biological tracers and biomarkers (eds. C. Hillaire-Marcel \& A. de Vernal). Elsevier, Amsterdam, 263-325.

Kaiho, K. \& Lamolda, M. A. 1999. Catastrophic extinction of planktonic foraminifera at the Cretaceous/Tertiary boundary evidenced by carbon and oxygen isotopes at Caravaca, Spain. Geology, 37, 355-358.

Kaiho, K., Kajiwara, Y., Tazaki, K., Ueshima, M., Takeda, N., Kawahata, H., Arinobu, T., Ishiwatari, R., Kirai, A. \& Lamolda, M. A. 1999. Oceanic primary productivity and dissolved oxygen levels at the Cretaceous/Tertiary boundary: their decrease, subsequent warming, and recovery. Paleoceanography, 14, 511-524.

Kajiwara, Y. \& Kaiho, K. 1992. Oceanic anoxia at the Cretaceous-Tertiary boundary supported by the sulfur isotope record. Palaeogeography, Palaeoclimatology, Palaeoecology, 99, 151-162.

Keller, G. 1989a. Extended Cretaceous/Tertiary boundary extinctions and delayed population changes in planktonic foraminifera from Brazos River, Texas. Paleoceanography, 4, 287-332.

Keller, G. 1989b. Extended period of extinctions across the Cretaceous/Tertiary boundary in planktonic foraminifera of continental shelf sections: Implications for impact and volcanism theories. Geological Society of America Bulletin, 101, 1408-1419.

Keller, G. 2003. Biotic effects of impacts and volcanism. Earth and Planetary Science Letters, 215, 249-264.

Keller, G. \& Stinnesbeck, W. 1996. Sea-Level Changes, Clastic Deposits, and Megatsunamis across the Cretaceous-Tertiary Boundary. In: Cretaceous-Tertiary mass extinctions. Biotic and Environmental Changes (eds. N McLeod \& G. Keller). W.W. Norton \& Company, 415449.

Keller, G., López-Oliva, J. G., Stinnesbeck, W. \& Adatte, T. 1997. Age, stratigraphy and deposition of near-K/T siliciclastic deposits in Mexico: relation to bolide impact? Geological Society of America Bulletin, 109, 410-428.

Klaus, A., Norris, R. D., Kroon, D. \& Smit, J. 2000. Impactinduced mass wasting at the K-T boundary: Blake Nose, western North Atlantic. Geology, 28, 319-322. 
Kuhnt, W. \& Kaminski, M. A. 1993. Changes in the community structure of deep water agglutinated foraminifers across the K/T boundary in the Basque Basin (Northern Spain). Revista Española de Micropaleontología, 25, 57-92.

Kyte, F. T., Zhou, Z. \& Wasson, J. T. 1980. Siderophile-enriched sediments from the Cretaceous-Tertiary boundary. Nature, 288, 651-656.

Loeblich, A. R. \& Tappan, H. 1987. Foraminiferal genera and their classification. Van Nostrand Reinhold Company, New York, 2 vol., 1182 pp.

Marie, P. 1941. Les foraminifères de la Craie à Belemnitella mucronata du Basin de Paris. Mémoires du Musée National d'Histoire Naturelle, 12, 1-296.

Marsson, Th. 1878. Die Foraminiferen der Weissen Schreibkreide der Insel Rügen. Mittheilungen des naturwissenschaftlichen Vereins für Neu-Vorpommern und Rügen in Greifswald, 10, 115-196.

Martínez-Ruiz, F., Ortega-Huertas, M., Palomo, I. \& Barbieri, M. 1992. The geochemistry and mineralogy of the Cretaceous-Tertiary boundary at Agost (southeast Spain). Chemical Geology, 95, 265-281.

Mallory, V. S. 1959. Lower Tertiary biostratigraphy of the California Coast Ranges. American Association of Petroleum Geologists, Tulsa, Oklahoma, 1-416.

McNeil, D. H. \& Caldwell, W. G. E. 1981 Cretaceous Rocks and their foraminifera in the Manitoba escarpment. The Geological Association of Canada, Special Paper, 21, 1-439.

Molina, E., Arenillas, I. \& Arz, J. A. 1998. Mass extinction in planktic foraminifera at the Cretaceous/Tertiary boundary in subtropical and temperate latitudes. Bulletin de la Société Géologique de France, 169, 351-363.

Molina, E., Alegret, L., Arenillas, I., Arz, J.A., Martínez, F., Ortega, M., Palomo, I. \& Rodríguez, F. 2001. Field-trip guide to the Agost and Caravaca sections (Betic Cordille$\mathrm{ra}$, Spain). $6^{\text {th }}$ Workshop Esf-Impact, Granada, $72 \mathrm{pp}$.

Molina, E., Alegret, L., Arenillas, I., Arz, J. A., Gallala, N., Hardenbol, J., von Salis, K., Steutbaurt, E., Vandenberghe, N. \& Zaghbib, D. 2006. The Global Boundary Stratotype Section and Point for the base of the Danian Stage (Paleocene, Paleogene,"Tertiary”, Cenozoic) at El Kef, Tunisia: original definition and revision. Episodes, 29, 263-273.

Murray, J.W. 1991. Ecology and palaeoecology of benthic foraminifera. Elsevier, Amsterdam, 397 pp.

Nakkady, S. E. 1950. A new foraminiferal fauna from Esna Shales and Upper Cretaceous Chalk of Egypt. Journal of Paleontology, 24, 675-692.

Norris, R. D., Kroon, D., Klaus, E. et al., 1998. Proceedings of the Ocean Drilling Program Initial Reports, 171B. College Station, TX (Ocean Drilling Program).

Nuttall, W. L. F. 1930. Eocene foraminifera from Mexico. Journal of Paleontology, 4, 271-293.

Parker, W. K. \& Jones, T. R. 1862. Introduction to the study of foraminifera. Ray Society, London, $184 \mathrm{pp}$.

Peryt, D., Alegret, L. \& Molina, E. 2002. The Cretaceous/ Paleogene (K/P) boundary at Aïn Settara, Tunisia: restructuring of benthic foraminiferal assemblages. Terra Nova, 14, 101-107.
Peryt, D., Alegret, L. \& Molina, E. 2004. Agglutinated foraminifers and their response to the Cretaceous/Paleogene boundary event at Aïn Settara, Tunisia. In: Proceedings of the Sixth International Workshop on Agglutinated Foraminifera (eds. M. Bubík \& M. A. Kaminski) Grzybowski Foundation Special Publication, 8, 393-412.

Plummer, H. J. 1926. Foraminifera of the Midway Formation in Texas. University of Texas Bulletin, 2644, 1-201.

Reuss, A. E. 1844. Geognostische Skizzen aus Böhmen. C. W. Medau, Prague, 2, 1-304.

Reuss, A. E. 1845. Die Versteinerungen der böhmischen Kreideformation, Erste Abtheilung. Schweizerbart, Stuttgart, 1-57.

Reuss, A. E. 1851. Die Foraminiferen und Entomostraceen des Kreidemergels von Lemberg. Naturwissenschaftliche Abhandlungen, Wien, 4, 17-52.

Sandidge, J. R. 1932. Foraminifera from the Ripley formation of western Alabama. Journal of Paleontology, 6 , 265-287.

Sharpton, V. L., Dalrymple, G. B., Marín, L. E., Ryder, G., Schuraytz, B. C. \& Urrutia-Fucugauchi, J. 1992. New links between the Chicxulub impact structure and the Cretaceous/Tertiary boundary. Nature, 359, 819-821.

Signor, P. W. \& Lipps, J. H. 1982. Sampling bias, gradual extinction patterns, and catastrophes in the fossil record. Geological Society of America Special Paper, 190, 291298.

Smart, C. W. \& Thomas, E. 2006. The enigma of early Miocene biserial planktic foraminifera. Geology, 34, 1041-1044.

Smit, J. 1990. Meteorite impact, extinctions and the Cretaceous-Tertiary Boundary. Geologie en Mijnbouw, 69, 187-204.

Smit, J. \& Hertogen, J. 1980. An extraterrestrial event at the Cretaceous-Tertiary boundary. Nature, 285, 198-200.

Smit, J. \& Ten Kate, W. G. H. Z. 1982. Trace-element patterns at the Cretaceous-Tertiary boundary-Consequences of a large impact. Cretaceous Research, 3, 307-332.

Smit, J. \& Romein, A. J. T. 1985. A sequence of events across the Cretaceous-Tertiary boundary. Earth and Planetary Science Letters, 74, 155-170.

Smit, J., Roep, Th. B., Alvarez, W., Montanari, A., Claeys, P., Grajales-Nishimura, J. M. \& Bermudez, J. 1996. Coarsegrained, clastic sandtone complex at the Cretaceous/Tertiary boundary around the Gulf of Mexico: Deposition by tsunami waves induced by the Chicxulub impact? Geological Society of America Special Paper, 307, 151-182.

Soria, A. R., Liesa-Carrera, C. L., Mata, M. P., Arz, J. A., Alegret, L., Arenillas, I. \& Meléndez, A. 2001. Slumping and a sandbar deposit at the Cretaceous/Tertiary in the El Tecolote sector (northeastern Mexico): An impact induced sediment gravity flow. Geology, 29, 231-234.

Thomas, E. 1990a. Late Cretaceous through Neogene deepsea benthic foraminifers (Maud Rise, Weddell Sea, Antarctica). Proceedings Ocean Drilling Program, Scientific Results, 113, 571-594.

Thomas, E. 1990b. Late Cretaceous-early Eocene mass extinctions in the deep sea. In: Global Catastrophes in Earth 
History (eds. V. L. Sharpton \& P. D. Ward). Geological Society of America Special Publication, 247, 481-495.

Thomas, E., Zachos, J. C. \& Bralower, T. J. 2000. Deep-Sea Environments on a Warm Earth: latest Paleocene-early Eocene. In: Warm Climates in Earth History (eds. B. Huber, K. MacLeod \& S. Wing). Cambridge University Press, 132-160.

Thomas, E., Schmidt, D., Alegret, L., Bernaola, G., Kroon, D., Lohmann, K., Monechi, S., Roehl, U. \& Westerhold, T. 2007. Effects of the end Cretaceous asteroid impact, Walvis Ridge, SE Atlantic Ocean. 9th International Conference on Paleoceanography ICP9, Shanghai.

Toulmin, L. D. 1941. Eocene smaller foraminifera from the Salt Mountain Limestone of Alabama. Journal of Paleontology, 15, 567-611.
Van Morkhoven, F. P. C. M., Berggren, W. A. \& Edwards, A. S. 1986. Cenozoic cosmopolitan deep-water benthic foraminifera. Bulletin du Centre des Recherchers Exploration-Production Elf-Aquitaine, 11, 1-421.

White, M. P. 1928. Some index foraminifera of the Tampico Embayment area of Mexico. Part II. Journal of Paleontology, 2, 280-317.

Wicher, C. A. 1949. On the age of the higher Upper Cretaceous of the Tampico Embayment area in Mexico, as an example of the worldwide existence of microfossils and the practical consequences arising from this. Bulletin $d u$ Mussée d'Histoire naturelle du Pays Serbe, 2, 76-105.

Manuscrito recibido: 24 de Septiembre, 2007 Manuscrito aceptado: 18 de Febrero, 2008

Apéndice I. Lista taxonómica con las referencias originales de las especies de foraminíferos bentónicos representadas en la figura 2. Taxonomic list including the original references of the benthic foraminiferal species plotted in figure 2.

Alabamina wilcoxensis Toulmin

1941 Alabamina wilcoxensis Toulmin, p. 603, lám. 81, figs. 1014; textfig. 4A-C.

Anomalinoides acutus (Plummer)

1926 Anomalina ammonoides (Reuss) var. acuta Plummer, p. 149, lám. 10, figs. 2a-c.

Anomalinoides ammonoides (Reuss)

1844 Rotalina ammonoides Reuss, p. 214.

Anomalinoides rubiginosus (Cushman)

1926 Anomalina rubiginosa Cushman, p. 607, lám. 21, figs. 6a-c.

Anomalinoides susanaensis (Browning)

1959 Cibicides susanaensis Browning (en Mallory, 1959), p. 271, lám. 32, figs. 11, 12.

Arenoturrispirillina tunisiana Peryt, Alegret \& Molina. 2004 Arenoturrispirillina tunisiana Peryt, Alegret \& Molina, p. 402, lám. 1, figs. 5-7.

Bolivinoides delicatulus Cushman 1927 Bolivinoides decorata (Jones) var. delicatula Cushman, p. 90, lám. 12, fig. 8.

Bolivinoides draco (Marsson) 1878 Bolivina draco Marsson, p. 157, lám. 3, fig. 25.

Bulimina strobila Marie

1941 Bulimina strobila Marie, p. 265, lám. 32, fig. 302.

Cibicidoides abudurbensis (Nakkady)

1950 Cibicides abudurbensis Nakkady, p. 691, lám. 90, figs. 35-38.

Cibicidoides alleni (Plummer)

1926 Truncatulina alleni Plummer, p. 144, lám. 10, fig. 4.
Cibicidoides ekblomi Brotzen

1948 Cibicidoides ekblomi Brotzen, p. 82, lám. 13, fig. 2.

Cibicidoides howelli (Toulmin)

1941 Cibicides howelli Toulmin, p. 609, lám. 82, figs. 16-18.

Cibicidoides hyphalus (Fisher)

1969 Anomalinoides hyphalus. Fisher, p. 198, fig. 3.

Cibicidoides proprius Brotzen

1948 Cibicidoides proprius Brotzen, p. 78, lám. 12, figs. 3, 4.

Cibicidoides pseudoacutus (Nakkady)

1950 Anomalina pseudoacuta Nakkady, p. 691, lám. 90, figs. 29-32.

Coryphostoma decurrens (Ehrenberg)

1854 Grammostomum? decurrens Ehrenberg, p. 22, lám. 30, fig. 17 (fide Ellis \& Messina, Cat. Foram.)

Coryphostoma incrassata (Reuss)

1851 Bolivina incrassata Reuss, p. 45, lám. 4, fig. 13.

Coryphostoma incrassata gigantea (Wicher)

1949 Bolivina incrassata Reuss, forma gigantea Wicher, p. 57, lám. 5, figs. 2-3.

Eouvigerina subsculptura McNeil \& Caldwell 1981 Eouvigerina subsculptura (nomen novum) McNeil \& Caldwell, p. 21, lám. 18, figs. 20, 21.

Gaudryina pyramidata Cushman 1926 Gaudryina laevigata Franke var. pyramidata Cushman, p. 587, lám. 16, figs. 8a-b.

Gyroidinoides beisseli (White) emend. Alegret \& Thomas, 2001

1928 Gyroidina beisseli White, p. 291-292, lám. 39, figs. 7a-c. 
Gyroidinoides depressus (Alth)

1850 Rotalina depressa Alth, p.266, lám. 13, fig. 21.

Gyroidinoides girardanus (Reuss)

1851 Rotalina girardana Reuss, p. 73, lám. 5, fig. 34.

Gyroidinoides globosus (Hagenow) emend Alegret \& Thomas, 2001

1842 Nonionina globosa Hagenow, p. 574.

Loxostomoides applinae (Plummer)

1926 Bolivina applini Plummer, p. 69, lám. 4, fig. 1.

Nuttallides truempyi (Nuttall)

1930 Eponides truempyi Nuttall, p. 287, lám. 24, figs. 9, 13, 14

Oridorsalis plummerae (Cushman)

1948 Eponides plummerae Cushman, p. 44, lám. 8, fig. 9.

Osangularia plummerae Brotzen

1940 Osangularia plummerae Brotzen, p. 30, textfig. 8.

Paralabamina lunata (Brotzen)

1948 Eponides lunata Brotzen, p. 77, lám. 10, figs. 17, 18.

Praeglobobulimina quadrata (Plummer)

1926 Bulimina quadrata Plummer, p. 72, lám. 4, figs. 4, 5.

Pseudouvigerina plummerae Cushman

1927 Pseudouvigerina plummerae Cushman, p. 115, lám. 23, fig. 8 .
Pulsiphonina prima (Plummer)

1926 Siphonina prima Plummer, p. 148, lám. 12, fig. 4.

Pyramidina prolixa (Cushman \& Parker)

1935 Bulimina prolixa Cushman \& Parker, p. 98, lám. 15, fig. 5.

Repmanina charoides (Jones \& Parker)

1860 Trochammina squamata Jones \& Parker var. charoides Jones \& Parker, p. 304.

Sitella cushmani (Sandidge)

1932 Buliminella cushmani Sandidge, p. 280, lám. 42, figs. 18-19.

Sitella fabilis (Cushman \& Parker)

1936 Buliminella fabilis Cushman \& Parker, p. 7, lám. 2, fig. 5.

Sliteria varsoviensis Gawor-Biedowa

1992 Sliteria varsoviensis Gawor-Biedowa, p. 156, lám. 33, figs. 9-13.

Spiroplectammina spectabilis (Grzybowski)

1898 Spiroplecta spectabilis Grzybowski, p. 293, lám. 12, fig. 12.

Stensioeina beccariiformis (White)

1928 Rotalia beccariiformis White, p. 287, lám. 39, figs. 2a-4c.

Tappanina selmensis (Cushman)

1933 Bolivinita selmensis Cushman, p. 58, lám. 7, figs. 3, 4.

Valvalabamina lenticula (Reuss)

1845 Rotalina lenticula Reuss, p. 35, lám. 12, fig. 17. 


\title{
THE MYTH OF THE HIPPO-LIKE ANTHRACOTHERE: THE ETERNAL PROBLEM OF HOMOLOGY AND CONVERGENCE
}

\author{
Martin PICKFORD \\ Collège de France, and Département Histoire de la Terre, UMR 5143 du CNRS, \\ Case postale 38, 57 rue Cuvier, 75005, Paris. e-mail: pickford@mnhn.fr
}

Pickford, M. 2008. The myth of the hippo-like anthracothere: The eternal problem of homology and convergence. [El mito de la similitud entre antracoterios e hipopótamos: el eterno problema entre homología y convergencia.] Revista Española de Paleontología, 23 (1), 31-90. ISSN 0213-6937.

\begin{abstract}
The notion that anthracotheres had hippo-like body proportions, locomotion and lifestyles has been in the literature for so long, and has been repeated so many times, that it has taken on the aura of unquestionable truth. However, right from the beginning of studies into hippo-anthracothere relationships over a century and a half ago, observations were made that revealed the existence of fundamental differences in dental, cranial and postcranial anatomy in the two groups. From 1836 to 1991 two skeletal characters (a descending plate at the angle of the mandible, and raised orbits) have overshadowed all others in suggesting close relationships between hippos and a single anthracothere genus (Merycopotamus) later to be joined by a second genus, Libycosaurus, in 1991 for the descending angle, and 2003 for the raised orbits (Lihoreau, 2003; Pickford, 1991). Close examination of these structures reveals that they are not homologous in the two groups, yet they have played an inordinately stubborn role in interpretations of the relationships between them, featuring in papers as recently as 2005 . The rest of the skeleton and many cranio-dental features revealed, as early as 1836, that anthracotheres did not look particularly similar to hippos, either in gross body plan, or in details of the skeletal anatomy, observations that have been confirmed at irregular intervals ever since. Yet, despite the divergent morphology, most authors continued to attribute hippo-like locomotion, behaviour and ecology to the anthracotheres that they studied, whether anthracotheriines or bothriodontines.

Two broad themes have run side by side in the long history of study of hippo-anthracothere relationships, «homology versus convergence» and «early versus late divergence», early divergence implying the existence of a ghost proto-hippo lineage of some 30 million years duration. Indeed these two themes are linked together, in the sense that proponents of early divergence have tended to interpret the similarities between hippos and anthracotheres as convergences, whereas those who have proposed late divergence usually took the perceived similarities to represent homologies.

All these interpretations were played out within the context of a much broader background debate about monophyly or paraphyly of the artiodactyls, which was actively discussed in the Victorian era just as it is today. More recently, molecular studies have altered the scope of the debate, principally by indicating closer affinities between whales and hippos than between hippos and other artiodactyls. In the search for the ghost lineage that should link hippos to whales, some authors have recently suggested that anthracotheres fill the role «robustly», whereas others have suggested that anthracotheres are not closely related to hippos, whilst yet others have proposed that palaeochoerids or cebochoerids may represent the missing lineage. The aim of this paper is to review the possible role of anthracotheres in the evolution of hippopotamids. It is concluded that they played no part in it, whereas palaeochoerids could well represent the ghost lineage that has evaded scientists for more than a century.
\end{abstract}

Keywords: Hippopotamidae, Anthracotheriidae, Palaeochoeridae, evolution, homology, convergence, early/late divergence, history, phylogeny.

\section{RESUMEN}

La idea de que los antracoterios tienen proporciones, locomoción y modo de vida similar a los hipopótamos se encuentra desde hace tiempo en la bibliografía, y se ha repetido en tantas ocasiones que ha alcanzado un aura de verdad incontestable. Sin embargo, desde el inicio de los estudios de las relaciones entre hipopótamos y antraco- 
terios, hace más de 150 años, las observaciones realizadas han revelado que existían diferencias fundamentales entre ambos grupos en la anatomía dental, craneal y postcraneal. Desde 1836 a 1991 dos caracteres esqueléticos (rama mandibular prolongada inferiormente en su ángulo y órbitas elevadas) han obscurecido a todos los demás a la hora de sugerir la proximidad entre hipopótamos y un único género de antracoterios (Merycopotamus), al que después se le ha unido un segundo género, (Libycosaurus), por la prolongación inferior del ángulo de la mandíbula (Pickford, 1991) y por las órbitas elevadas (Lihoreau, 2003). El examen detallado de estas estructuras revelan que nos son homólogas en estos dos grupos, aunque de manera constante hayan jugado un importante papel en las interpretaciones de las relaciones entre ambos grupos, figurando incluso en trabajos del año 2005. El resto del esqueleto y muchos caracteres craneodentales conocidos ya desde 1836 revelan que los antracoterios no son particularmente semejantes a los hipopótamos, ni en la morfología corporal gruesa ni en detalles de la anatomía esquelética; estas observaciones se han confirmado repetidas veces desde entonces. A pesar de esta morfología divergente todavía hay numerosos autores que continúan atribuyendo a los antracoterios, sean antracoterinos o botriodontinos, una locomoción, comportamiento y ecología similar a los hipopótamos.

Dos ideas principales han ido paralelas a lo largo de la historia de los estudios sobre las relaciones entre hipopótamos y antracoterios, "homología versus convergencia" y "divergencia temprana versus divergencia tardía"; una divergencia temprana implicaría la existencia de un linaje proto-hipopótamo fantasma, con una duración de unos 30 millones de años. Señalar que estas dos ideas están muy ligadas, en el sentido de que los que propugnan una divergencia temprana tienden a interpretar las similitudes entre hipopótamos y antracoterios como convergencias, mientras aquellos quienes propugnan una divergencia tardía usualmente consideran las similitudes percibidas como homologías.

Todas estas interpretaciones también juegan un papel muy importante en un contexto mucho más amplio del debate sobre la monofilia o parafilia de los artiodáctilos, que se viene discutiendo activamente desde la era Victoriana hasta la actualidad. Recientemente, los estudios moleculares han alterado el ámbito del debate, principalmente al señalar una mayor afinidad entre las ballenas y los hipopótamos que entre éstos y los artiodáctilos. En la búsqueda de este linaje fantasma que debería enlazar hipopótamos y ballenas, algunos autores han sugerido que los antracoterios no tendrían una relación cercana con los hipopótamos, mientras otros sugieren que los paleoquéridos o ceboquéridos podrían representar el linaje perdido. La idea de este trabajo es revisar el posible rol jugado por los antracoterios en la evolución de los hipopotámidos. La conclusión es que los antracoterios no juegan ningún papel en ella, además los paleoquéridos bien podrían representar el linaje fantasma, que se ha evadido a las pesquisas de los científicos durante más de un siglo.

\section{Palabras clave: Hippopotamidae, Anthracotheriidae, Paleochoeridae, evolución, homología, convergencia, divergencia temprana/tardía, historia, filogenia.}

\section{INTRODUCTION}

The origin of Hippopotamidae has been the subject of enquiry for more than a century and a half, yet at the beginning of the 21 st Century it is still a matter for lively debate. Once it was realised that pachyderms [an early concept (Cuvier, 1822) linking divergent mammalian groups on the basis of their thick skin] in which hippos were once classified, was not a natural grouping (or clade) the family Hippopotamidae has been included in the Order Artiodactyla (or conceptual precursors of this order such as Paridigitata) on account of its even toed acropodes, double-trochleated talus, the keeled occipital condyles and the presence of a three-lophed $\mathrm{d} / 4$ in the milk dentition, and usually within the Suborder Suiformes because of its pig-like talar anatomy, bunodont cheek teeth and non-ruminating digestive system.

Recent molecular work has stimulated interest in the family because the analyses suggest that hippos have molecular signatures that are closer to those of whales than to those of other artiodactyls, including other Suiformes.
Underpinning the long debate about hippopotamid origins is the enduring uncertainty about the monophyly of the Order Artiodactyla. In the Victorian era, the debate was lively, although not couched in the same terms that we would use today. Nevertheless, much of the literature of the period reveals that many fossil artiodactyls did not fit into the two broadly accepted suborders - Suiformes and Ruminantia -into which extant forms could be classified. Because of this researchers tended to look for evidence to link their fossils either with the ruminants or with the suiforms [groups such as Pachysimia (eg Lydekker, 1883) which were for a time linked with Artiodactyla, are no longer recognised as being valid - genera such as Cebochoerus Gervais, 1848, formerly classed within them have been absorbed into the Suiformes]. Hippopotamidae were classified by most workers in Suiformes (or variants of the same, such as Suina) clearly distinguished from Ruminantia by the talar morphology among other features (dentition, cranial morphology, non-ruminating stomach).

The challenge of hippo-whale relationships was taken up by Boisserie et al. (2005a, 2005b) who postulated that 
anthracotheres, in particular bothriodonts, represent the ghost lineage linking the base of the whale radiation (ca $55 \mathrm{Ma}$ ) to that of the hippos (ca $15 \mathrm{Ma}$ ). Two characters in particular (raised orbit and descending angle of the jaw) featured prominently in these papers, just as they did in publications by Lydekker $(1876,1883)$ more than a century ago. However, Boisserie (pers. comm. 2006) agrees that these two characters are not synapomorphies shared by hippos and anthracotheres, and that they should no longer be used as such in cladistic analyses.

The history of interpretations of the Artiodactyla is extremely complicated, mainly because the order is rich in species and has a lengthy fossil record (ca 55 million years) and is geographically widespread (all continents except Antarctica and Australia) (Matthew, 1934). Since molecular biologists entered the arena, the diversity of interpretations has increased.

The Victorian view of a rather clearcut subdivision of living Artiodactyla into two broad subgroups (ruminants and non-ruminants) (Kowalevsky, 1874; Lydekker, 1883) was rendered less evident once fossils were included, because there were some groups, notably the anthracotheres, that showed a puzzling mixture of characters, some such as the talar morphology suggesting affinities to Suiformes, others such as the selenodont dentition indicating relationships to Ruminantia (Lydekker, 1883). For a while the intermediate nature of anthracotheres was taken by those who considered Artiodactyla to be monophyletic, as evidence that they linked the Suiformes to the Ruminantia (Lydekker, 1883) thereby supporting their hypothesis of monophyly, but others such as Kowalevsky $(1873,1874)$ considered that the Suiformes (his Paridigitata bunodonta or Suina) and Ruminantia (his Paridigitata selenodonta) diverged before the Eocene (note that at the time, the Eocene was considered to be preceded immediately by the Cretaceous and succeeded by the Miocene) (Fig. 1). This led Lydekker (1877) to comment that «according to Kowalevsky's plan of evolution there can have been no connection between the original stocks of Hippopotamus Linnaeus, 1758, and Merycopotamus Falconer \& Cautley,

\section{Paridigitata selenodonta}

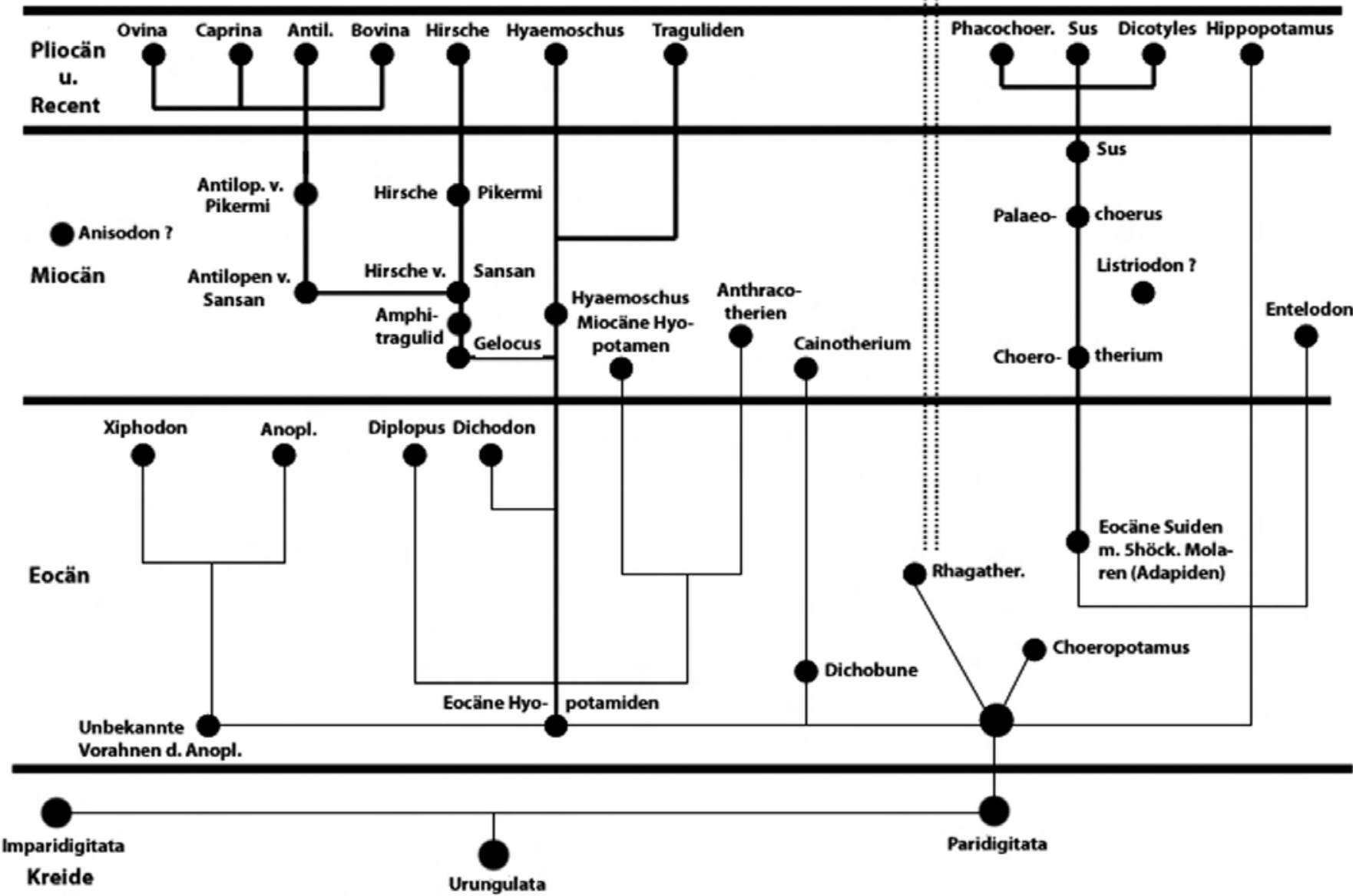

Figure 1. Artiodactyl phylogeny published by Kowalevsky (1874). In the interests of clarity, I have omitted the Imparidigitata (perissodactyls) and some of the morphological comments. 
1848, since the lower Eocene period». Lydekker (1876, 1883) envisaged a much closer «cousinship» as he put it, linking these genera as recently as the end of the Miocene or even the Pliocene. The geologically youthful linking of these genera has recently resurfaced (Boisserie \& Lihoreau, 2006; Boisserie et al. 2005a, 2005b) but the phylogenetic context has changed. In the latest scenario, the anthracotheres were envisaged as representing the missing link between Cetacea and Hippopotamidae, with other artiodactyls considered as outgroups of a HippoWhale clade within Cetartiodactyla (combined Cetacea and Artiodactyla).

It is within this changing panorama of artiodactyl phylogeny that researchers have endeavoured to resolve the issue of hippopotamid origins. It is not only the concepts and contents of the Order Artiodactyla that have changed over the years, but also the concepts and contents of lower rank groups such as families within it. The family Suidae provides a fine example. In the early part of the last century, Matthew $(1929 b, 1934)$ wrote that hippos certainly did not descend from anthracotheres but from Suidae. At the time of his writing the family Suidae was an amalgam of what we would today classify into four or five different families [Suidae (sensu stricto), Tayassuidae (New World Peccaries), Sanitheriidae and Palaeochoeridae (Old World Peccaries), and possibly Cebochoeridae depending on how one reads his 1934 chart]. Even though Matthew has been credited with the suid hypothesis of hippo origins (Colbert, 1935) detailed reading of his works indicate that he envisaged a closer relationship between North American Oligo-Miocene peccaries and hippos than between true pigs and hippos, although his 1934 chart is not consistent with his $1929 \mathrm{~b}$ text. This did not prevent subsequent authors from comparing hippos only with pigs and anthracotheres (Colbert, 1935) just as Lydekker (1876) had done before him, neglecting the Oligo-Miocene peccaries and other suoids, thereby compromising their research efforts, and as a result producing incomplete comparisons and flawed results.

Since the advent of cladistics, it has become evident, if it weren't before, that sample choice is of primordial importance for any phylogenetic analysis. The problem of missing taxa and missing data (of included taxa) is universal, and renders all phylogenetic analyses liable to modification. Thus Colbert's (1935) analysis of hippopotamid origins was bound to fail, because he did not include all the relevant groups in his study. Recent propositions by Boisserie et al. (2005a, 2005b) are compromised for much the same reason, the Palaeochoeridae (although not named as such) in their analyses being represented by a single genus, for which more than $22 \%$ of the characters analysed could not be scored, while the post-cranial skeleton was represented by only the talus and the distal metapodials.

\section{MATERIALS AND METHODS}

This examination of the relationships between hippopotamids, palaeochoerids and anthracotheres is based on comparative osteology and odontology, but because the palaeochoerids and anthracotheres are extinct, it mentions only briefly the debate concerning the place of hippopotamids in the Cetartiodactyla based on molecular analyses. The approach is basically historical and summarises the various hypotheses of hippopotamid origins and the evidence used to support those hypotheses.

\section{A WORD ABOUT Palaeochoerus AND THE FAMILY PALAEOCHOERIDAE}

The attribution of certain fossils from St-Gérand-lePuy, Allier, France, to the genus Palaeochoerus erected by Pomel (1847) has caused unending problems which still bedevil the interpretation of the suoid fossil record. In effect, there are at least two genera of pig-like suoids at the locality (Orliac, pers. comm. suggests that there are four suoid taxa at the site) a small form with two cusps in the upper $\mathrm{P} 4 /$, no pentacone in the $\mathrm{M} 3$ / and no ridges on the anterior aspect of the distal metapodial epiphysis. These are genuine Palaeochoerus by definition (see discussion in Ginsburg, 1974). In contrast the larger fossils with tricuspid P4/s, M3/s with a pentacone, and distal metapodial epiphyses with a well developed anterior crest belong to Hyotherium Von Meyer, 1834. Both Kowalevsky (1874) and Pearson (1927) and many other researchers (see a partial list in Van der Made, 1996) failed to notice the misattribution of these fossils, as did Viret (1961) who even erroneously identified the large skull of Hyotherium as the type specimen of Palaeochoerus typus Pomel, 1847. It wasn't until Ginsburg's (1974) publication that the confusion was clarified, although his correction passed almost unnoticed because it is hidden in the general discussion of his paper. Van der Made (1996) erroneously includes Ginsburg's (1974) paper among those that failed to make the distinction, despite the fact that his was the first paper since Pomel (1847) to correctly identify the skull. The confusion has proved remarkably difficult to eradicate as it is still present in papers by Boisserie et al. (2005a, 2005b).

Matthew (1924) erected the subfamily Palaeochoerinae for a subgroup of Suidae comprising Palaeochoerus from Europe, and Perchoerus Leidy, 1869, Thinohyus Marsh, 1875, Bothrolabis Cope, 1888, and Chaenohyus Cope, 1879, from America. This name initially failed to make any impact for two reasons. Firstly, New World Peccaries were already classified in Tayassuidae (Palmer, 1897) or Dicotylidae (Gray, 1868) depending on the researcher, and secondly, most scientists considered that Palaeochoerus was a suid, being confused by the mix-up in the material from St-Gérand-le-Puy, as explained above. Naturally, interpretation of Palaeochoeridae will differ if 


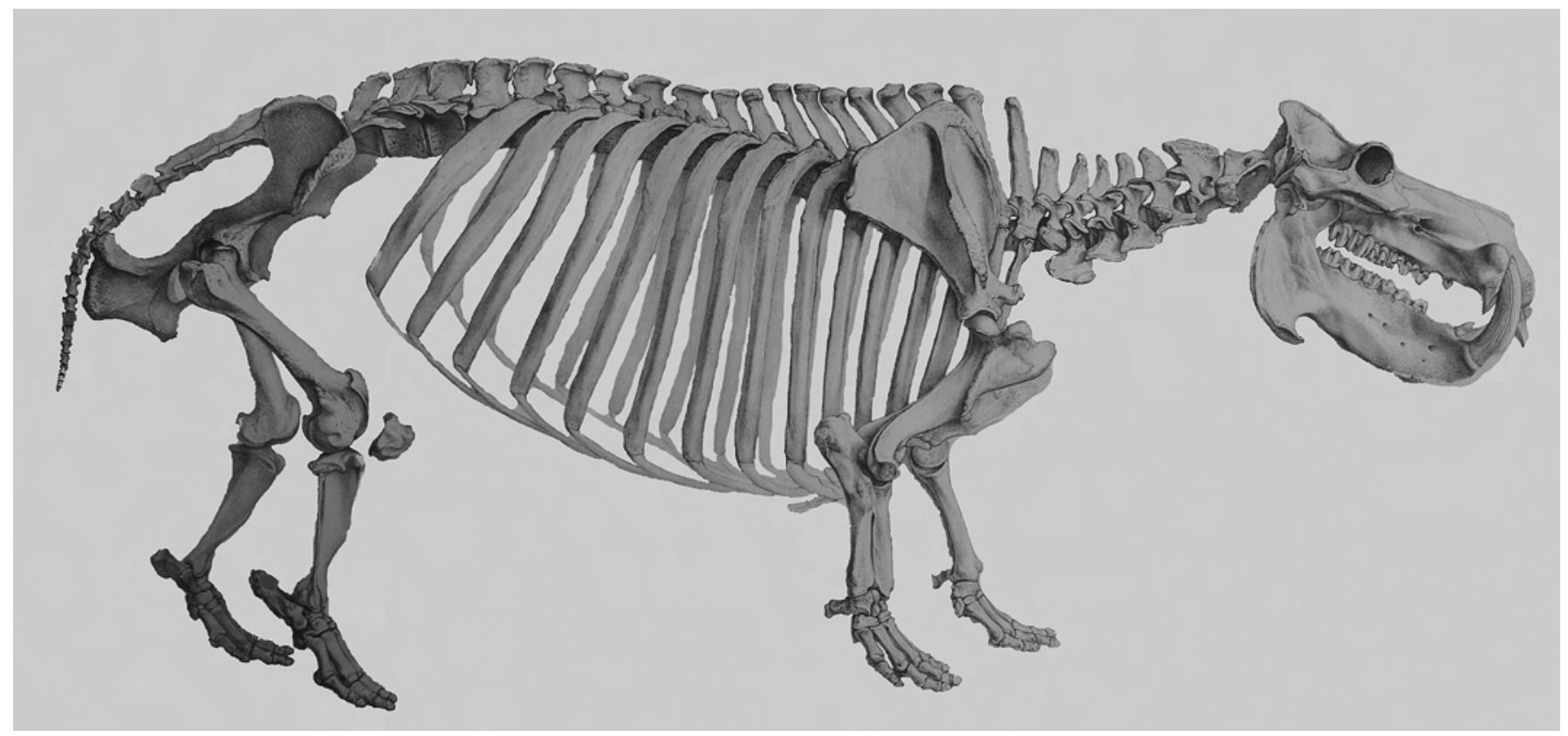

Figure 2. Lateral view of skeleton of Hippopotamus Linnaeus, 1758, showing the deep barrel-shaped thorax and the short limbs (modified from de Blainville, 1846).

one includes the skull and postcranials of Hyotherium in it or excludes them.

Van der Made $(1996,1997)$ resurrected the name, raising it to family rank (Palaeochoeridae) but he excluded the North American taxa from it.

\section{A WORD ABOUT AMPHIBIOUS ADAPTATIONS OF HIPPOPOTAMIDS AND THE IMPORTANCE OF POST-CRANIAL BONES}

Kowalevsky (1874) Lydekker (1876) and Matthew (1929a) were all of the opinion that for gaining an understanding into the relationships between artiodactyl genera, it was essential to examine the post-cranial skeleton. The main interest in the post-cranial bones, apart from the evidence they provide of a systematic nature, lies in what they can reveal about body proportions and locomotor repertoires as was shown by Kowalevsky (1874) for the Anthracotheriinae, Geais (1934) for the bothriodontine anthracotheres, and Boekschoten \& Sondaar (1966, 1972), Houtekamer \& Sondaar (1979) and Spaan (1996) for the hippopotamids.

Hippopotamids possess a unique set of features of the post-cranial skeleton and soft anatomy linked to their amphibious lifestyle, which requires that they move efficiently in water as well as on dry land. On the one hand their limbs and body show adaptations for terrestrial locomotion of up to several $\mathrm{km}$ per night while they forage and on the other they show adaptations for streamlining the body and limbs for efficient aquatic locomotion. In order to minimise the effects of drag, hippos have developed a unique body plan in which the body is barrel-shaped with such a deep rib cage that the humerus does not extend downwards beyond the ribs, but lies alongside them (Fig. 2). The humerus thus has skin covering only its lateral side, the medial part being entirely within the body. Indeed, in adults even the proximal part of the radio-ulna is within the body when the forearm is in flexed positions (Figs 3, 4). During swimming, the joints of the fore limb are hyperflexed onto each other to such an extent that the

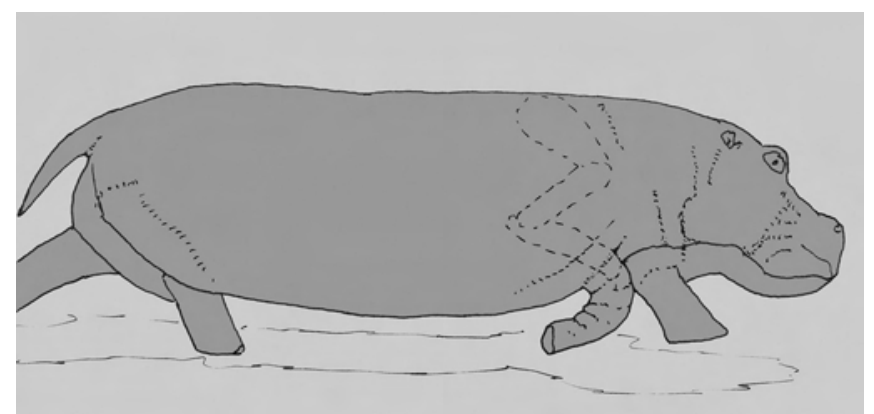

Figure 3. Hippopotamus amphibius Linnaeus, 1758, swimming. Note the position of the humerus and the proximal end of the radio-ulna retracted into the region of the thorax (the elongated appearance of the body is due to optical distortion by the lens of the camera). 


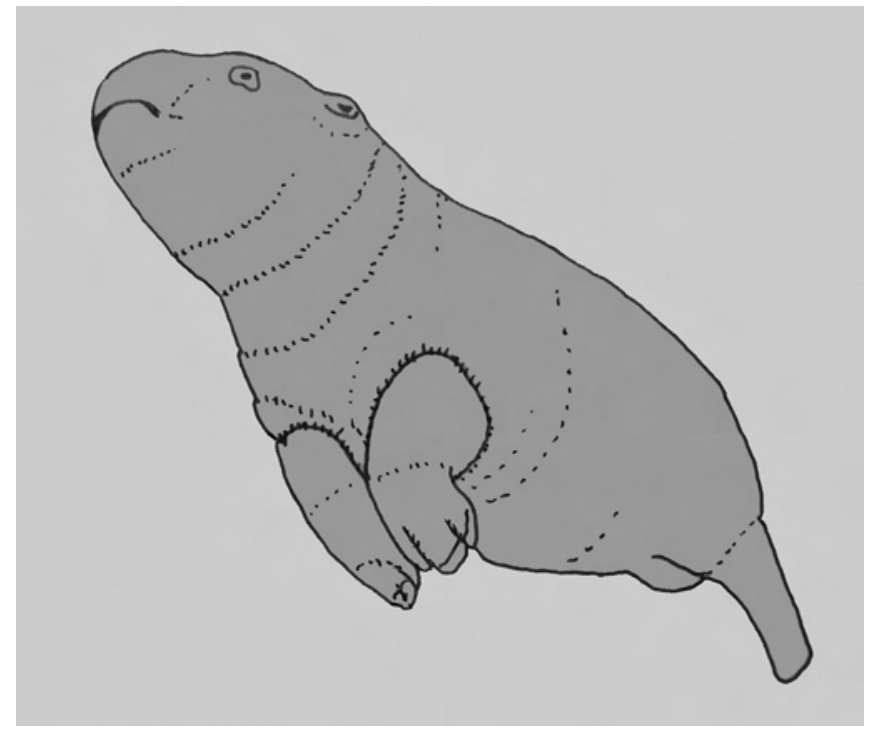

Figure 4. Choeropsis liberiensis (Morton, 1849) swimming. Note the fully retracted humerus and proximal radio-ulna, and the hyper-flexed metapodials and feet of the forelimbs as well as the streamlined positioning of the hind limbs, all of which minimise drag.

proximal half of the radius and ulna are withdrawn into the body around a deep fold in the skin, leaving only the distal part outside but held close to the rib cage beneath the neck, with the carpals, metapodials and phalanges folded back beneath, thereby reducing their coefficient of drag to a minimum (Figs 3,4). The hind limbs do not pose a significant streamlining problem, because during underwater swimming, they are pointed backwards in line with the rear of the barrel-shaped body. However, the femur is largely enveloped in a fold of skin that continues the profile of the side of the body, so that when the leg is swung forwards during underwater walking or swimming, only the distal part of the tibia, the metapodials and phalanges are exposed to the water column (Fig. 4). This unique limb system of hippos resembles a semi-retractable undercarriage.

Furthermore, for an animal of its size and bulk, the hippopotamus is incredibly agile (Figs 3,5 ) both on land and in the water, being well known for its ability to turn 'on a dime', roll over in the water and twist and turn rapidly during ritual or real agonistic encounters with conspecifics. Hippos are however, unable to jump when on land and won't even step over low hurdles in their path. Hippos are exposed to predation in aquatic and terrestrial environments and the ability to turn rapidly is an important factor in predator avoidance.

The body of hippopotamids is slightly denser than water, but is bouyant enough that relatively minor forces are required to raise the body to the surface or to move it through the water. Hippos have been described as 'danc-

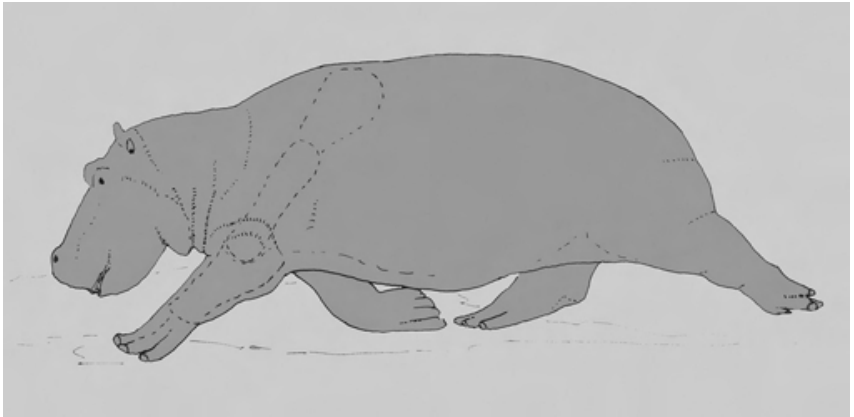

Figure 5. Hippopotamus amphibius Linnaeus, 1758, running on land. Note that even in the fully extended position, the humerus does not extend beneath the thorax.

ing' or 'gliding' above the bottom of the lakes and rivers that they inhabit, the limbs touching the ground relatively lightly to provide thrust, with the body 'floating' above the bottom (Fig. 3) often with all four legs off the ground while the body is moving forwards (Fig. 4). During «swimming», the front legs can be actively used for propulsion (broad radio-ulna, webbed foot) but foot contact with the bottom usually provides the main propulsive force.

Detailed examination of the anatomy of hippopotamid limb bones reveals that amphibious adaptations have occurred at several scales, from the overall shape and length of the diaphyses to the orientation of the articular epiphyses on the diaphyses, all of which increase the possibility of hyperflexion of the joints compared with the same joints in exclusively terrestrial artiodactyls. Other Suiformes, such as suids and anthracotheres, have proportionally longer limbs, straighter long bones with the epiphyses more in line with the diaphyses, less well developed potential for hyperflexion of the articulations, and the humerus extends well outside the body of the rib cage, and is completely surrounded by skin. In detail therefore, anthracotheres (Figs 6,7) did not have locomotor repertoires like those of hippopotamids, but more like those of suids and even some ruminants.

Given that many anthracothere fossils occur in lignites and other swamp deposits, it is possible that they lived somewhat like the extant sitatunga (Tragelaphus spekei Speke, 1863) an African bovid with comparable body proportions that spends much of its life in papyrus swamps and reed beds, foraging on dry land in the evenings, at night and in the early morning. Other ruminants with somewhat comparable habits are the Swamp Deer [Blastocerus dichotomus (Illiger, 1815)] of South America, the Sambar [Cervus unicolor (Kerr, 1792)] of India, and the Lechwe [Kobus leche (Gray, 1850)] of Africa. The major difference between these water-loving ruminants and hippos, is that they habitually keep the head and body emergent from the water, whereas hippos generally completely submerge their heads and bodies for long periods. 


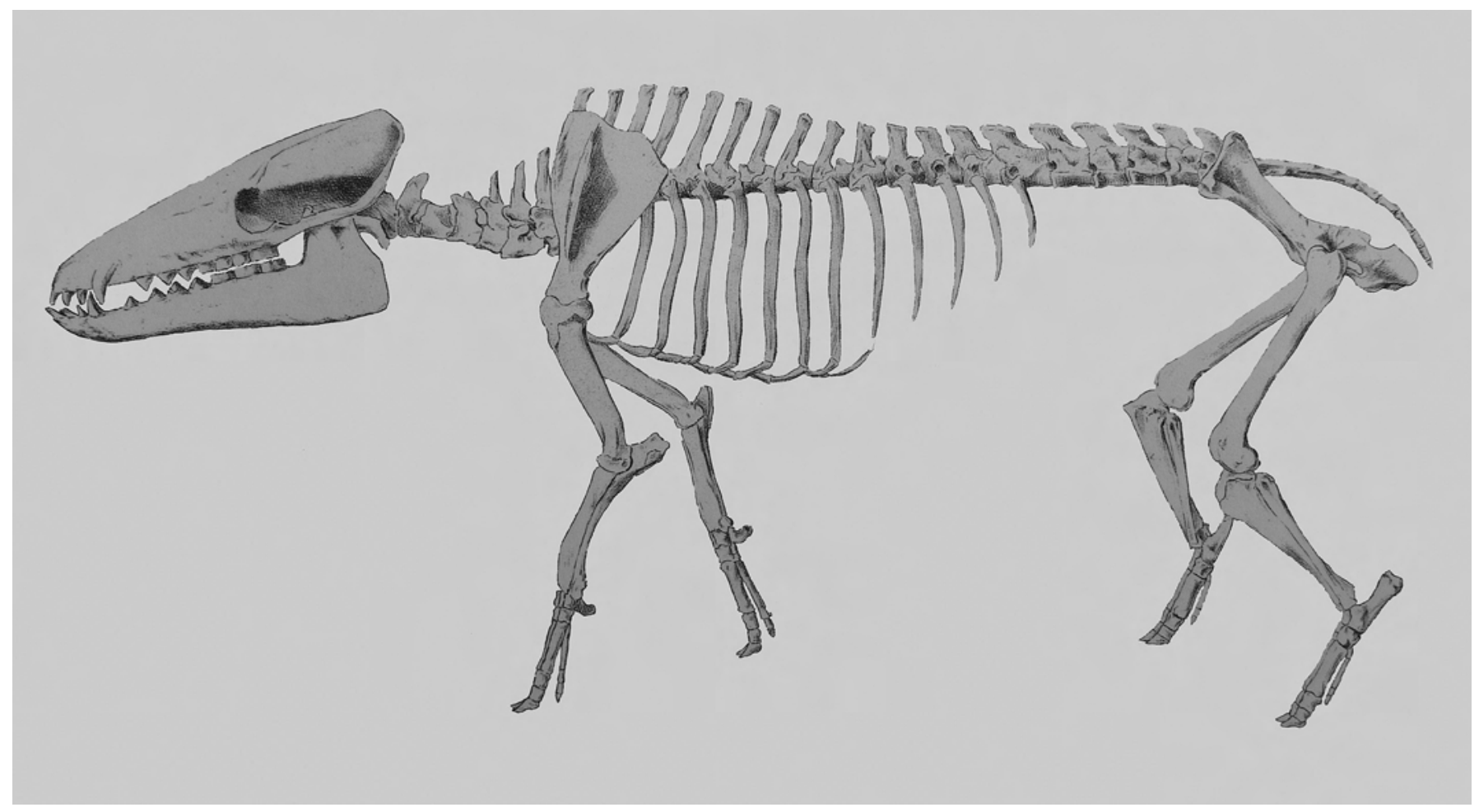

Figure 6. Anthracotherium magnum Cuvier, 1822, lateral view of skeleton, showing the elongated aspect of the limbs which extend well beneath the thorax (modified from Kowalevsky, 1874).

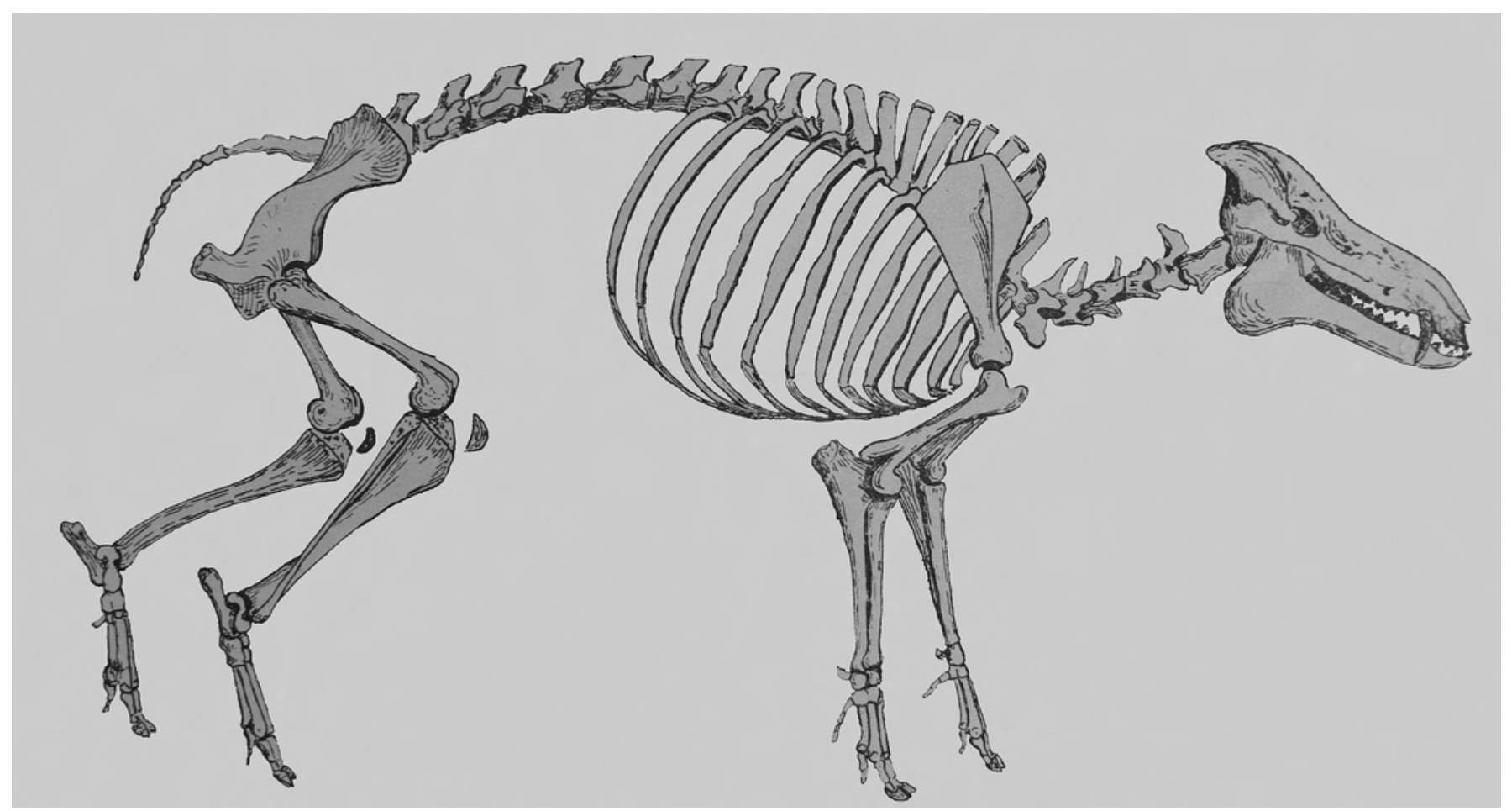

Figure 7. Elomeryx borbonicus (Gervais, 1852) lateral view of skeleton, showing the elongated aspect of the limbs which extend well beneath the thorax, as in suids and ruminants (modified from Geais, 1934). 
Even the huge Water Buffalo (Bubalus bubalis Linnaeus, 1758) of India, which has about the same dimensions as the large bothriodont, Brachyodus aequatorialis MacInnes, 1951, usually retains much of its body as well as its head emergent from the water, even when lying down in rivers and ponds.

When disturbed or threatened while in the water, Blastocerus, Cervus unicolor and Kobus leche all bound away, generally lifting the entire body well clear of the water at each bound. Hippos in contrast, when disturbed in shal- low water or on land, generally rush towards deeper water where they immediately submerge their heads and bodies completely. The strategies for dealing with danger in these two groups are thus radically different, and this is reflected in the locomotor apparatus and overall body plan. Because their post-cranial skeletons more closely resemble those of ruminants than hippos, bothriodont anthracotheres possibly behaved more like water-loving ruminants than hippos, generally keeping their bodies emergent while in shallow water, and usually avoiding deep water.

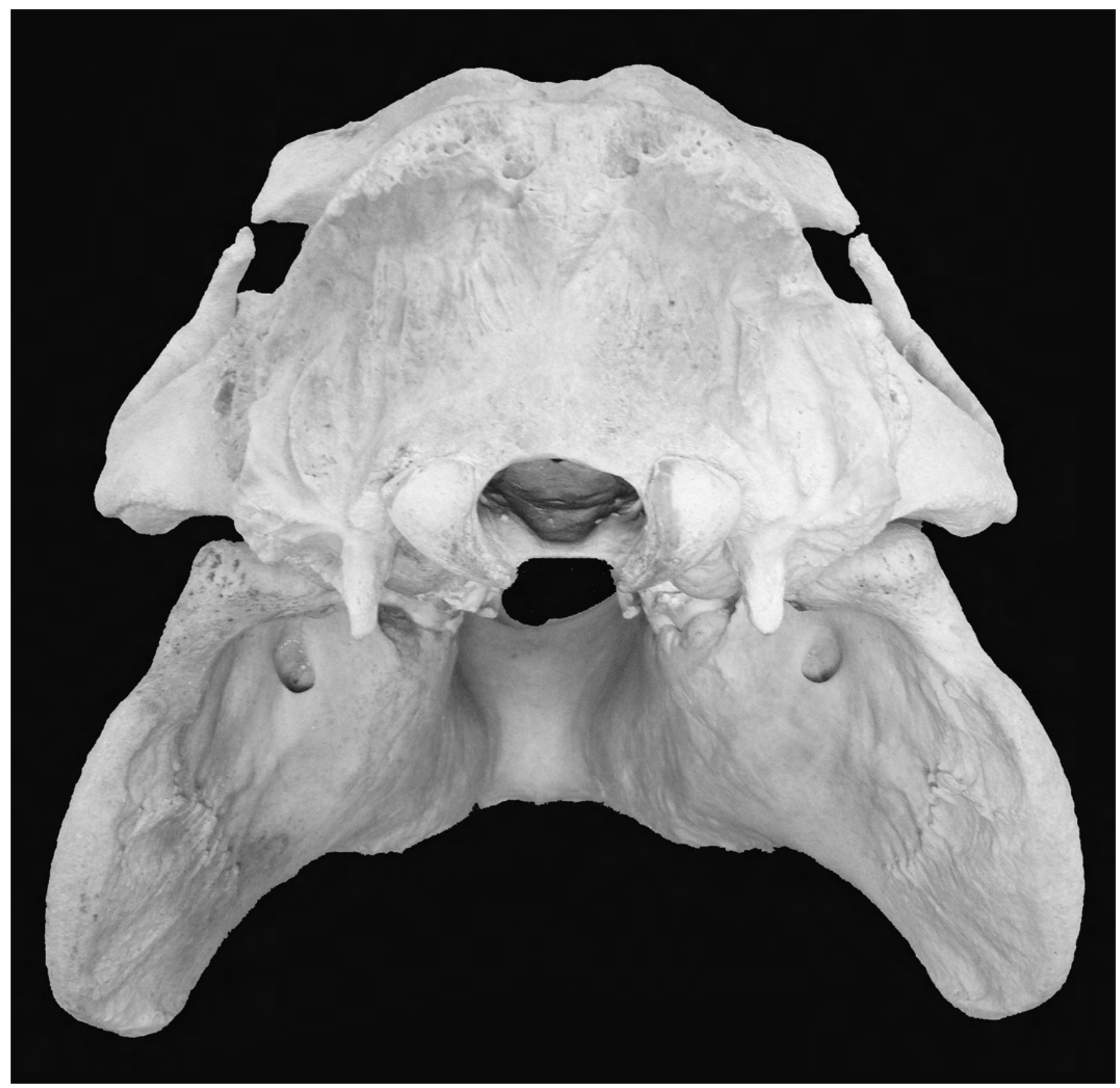

Figure 8. Choeropsis liberiensis (Morton, 1849) distal view of skull and mandible showing that the mandible is broader than the cranium, a feature unique to hippopotamids among mammals. 


\section{THE FLARED REAR OF THE MANDIBLE IN HIPPOS}

In hippos, the back of the mandibles flare laterally to a marked extent, producing a morphology unique among mammals, in that the back of the lower jaws is wider than the cranium (Fig. 8). In ventral view, the flared mandibles resemble the prow of a ship (Fig. 9) and in terms of amphibious locomotion, this peculiar morphology might play a role in reducing drag at the front of the body by streamlining the profile of the head and neck onto the barrel-like body. However, it is more likely that the flaring of the base of the mandible relates to the extraordinary gape that hippos have, especially during ritual "agonistic" or «intimidation» behaviour (inappropriately named the «yawning» display) (Fig. 10). If the distal part of the base of the two rami of the mandible were not flared, they would impinge on the neck when gape is wide, but splaying them laterally allows the jaw to be opened wide without interfering with it, the flared parts coming into position beside the neck. In extremely wide gape positions, the axis vertebra comes to lie between the upper parts of the flared plates of the lower jaw, something that would not be possible without the flaring.

\section{MOLECULAR EVIDENCE FOR AFFINITIES OF HIPPOPOTAMIDS}

During the 1990s, almost contemporary with the discovery of primitive fossil cetaceans preserving talar anatomy that suggested links between artiodactyls and whales (Thewissen et al., 1983, 1998, 2001; Gingerich et al., 2001) molecular biologists added to the debate about hippopotamid origins (Grauer \& Higgins, 1994; Xu et al., 1996; Gatesy, 1997, 1998; Gatesy et al., 1996, 1999; de Jong, 1998; Hasegawa \& Adachi, 1996; Hasegawa et al., 1997; Milinkovitch \& Thewissen, 1997; Montgelard et al., 1997a, 1997b; Shimamura et al., 1997, 1999; Milinkovitch et al., 1998; Nomura et al., 1998; Ursing \& Arnason, 1998; Kleineidam et al., 1999; Miyamoto, 1999; Nikaido et al., 1999; Nomura \& Yasue, 1999; Arnason et al., 2000, 2004; Shedlock et al., 2000; Ursing et al., 2000; Naylor \& Adams, 2001, 2003). Most molecular biologists have found the molecular evidence in support of a whale-hippo clade to be compelling, although not all morphologists agree with them (Geisler \& O’Leary, 1997; Geisler \& Luo, 1998; Luckett \& Hong, 1998; Gingerich \& Uhen, 1998; O'Leary, 1998, 1999, 2001; O'Leary \& Geisler, 1999; O'Leary \& Uhen, 1999; Gatesy \& O’Leary, 2001; Geisler, 2001; Langer, 2001; Geisler \& Uhen, 2003, 2006; O'Leary et al., 2003; Meisner et al., 2005; Theodor \& Foss, 2006). The molecular viewpoint culminated in the proposal of a Cetartiodactyla clade, the reality of which is the subject of debate, as are the details of relationships within this clade.

\section{HISTORICAL REVIEW: OSTEOLOGICAL STUDIES}

\author{
Falconer \& Cautley
}

Falconer \& Cautley (1836) were the first authors to describe fossil remains of what was eventually to be called Merycopotamus dissimilis (Falconer \& Cautley, 1836). In their initial paper they classified the fossils in the genus Hippopotamus, subgenus Hexaprotodon Falconer \& Cautley, 1836, but recognised that in some features, notably the dentition, it resembled ruminants more than hippos. They furthermore noted that the mandible was «peculiar» when compared to that of Hippopotamus, mainly in the slenderness of the ramus and the presence of a large notch between the descending plate at the angle of the jaw and the rest of the body (Fig. 11a, 12) in contrast to the «straight, thick, massive jaw» of hippos. They also noted the «elevated ridge pointing angularly forwards and pushing forward a nearly flat surface to the centre of the rear tooth» (Fig. 11a). After discussing the marked differences in breadth between the upper and lower molars, the authors closed by proposing to «establish a species with (in this respect) rather unusual peculiarities. To this smaller species we propose the name dissimilis, from the differences of form from the rest of the genus» (Hippopotamus). The authors also noted the ruminant-like narrowness of the lower molar row compared with the much broader upper molars, whereas suoids and hippos have less divergent molar row breadths.

The same authors erected the genus Merycopotamus in 1845 combining the Greek words for ruminant (merux) and river (potamos) (in Owen, 1845) but without naming a type species. Lydekker (1886) nominated the species dissimilis as the type species of the genus Merycopotamus, although the combination had been in use for some time before this publication (Falconer, 1868; Lydekker, 1876, 1883).

From these first hesitant interpretations of the fossils emerged the extremely tenacious but erroneous view that Merycopotamus was a hippo-like creature, even though Falconer \& Cautley (1836) recognised from the outset that within a hippo context it was «peculiar» and that it possessed ruminant-like features of the dentition (repeated in Owen, 1845). Falconer (1868) summarised Merycopotamus, stressing the ruminant-like aspect of the cheek dentition, contrasting with the hippo-like «cranium, incisors and canines, together with the leafy expansion of the angle of the lower jaw». His conclusion was that «Merycopotamus is a most interesting and well-marked genus, connecting Hippopotamus with Anthracotherium», a conclusion that was supported by Huxley (1871) and which echoes to this day (Boisserie et al., 2005a, 2005b). But is the skull, mandible, and anterior dentition of Merycopotamus similar to those of Hippopotamus, and if so, are the resemblances due to commonality of descent or to convergence? 


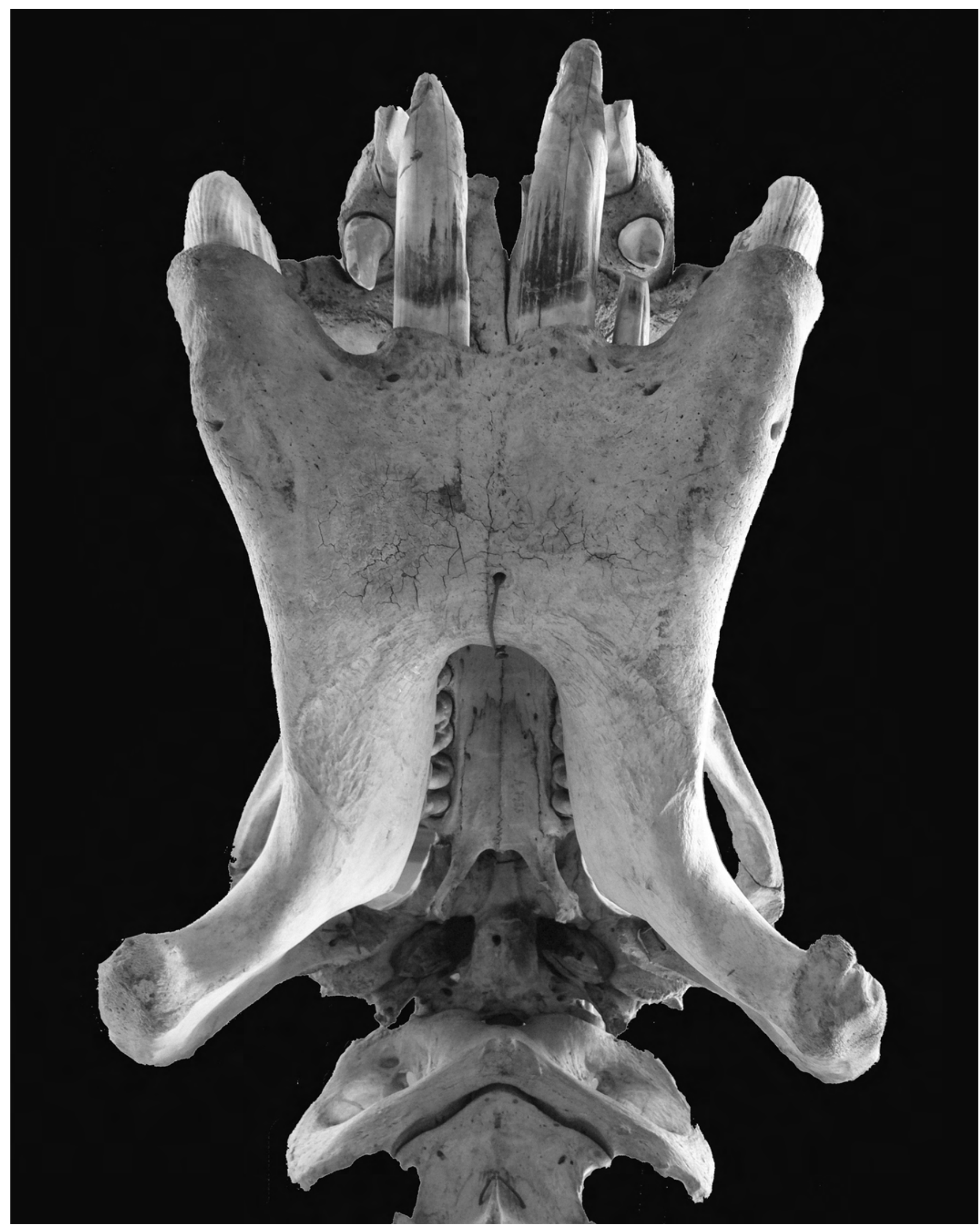

Figure 9. Hippopotamus amphibius Linnaeus, 1758, ventral view of skull and mandible showing the prow-shaped flare of the rear of the mandibles. The same morphology occurs in Choeropsis Leidy, 1853, but is unknown in anthracotheres and all other artiodactyls. 


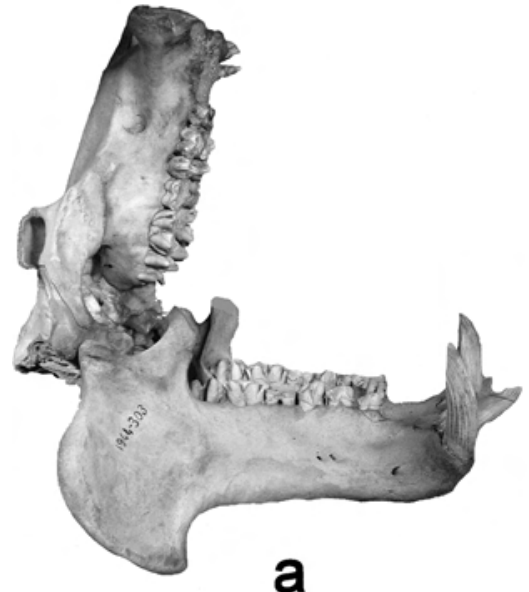

b

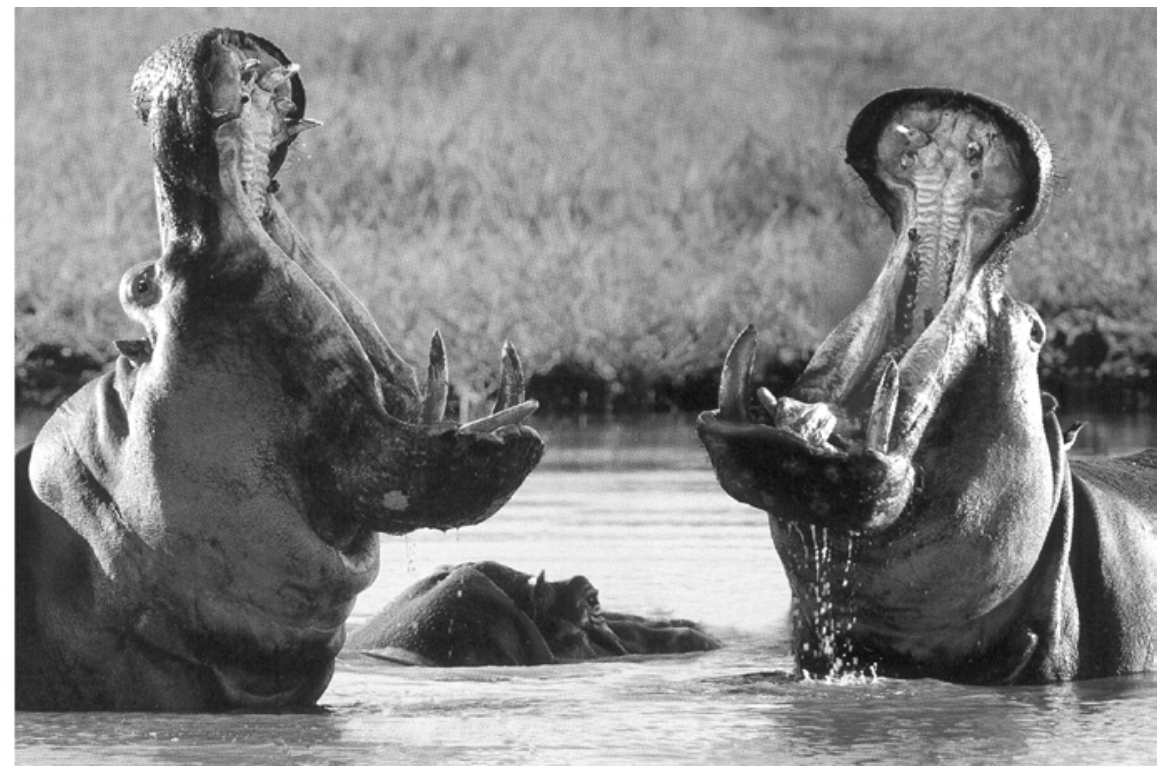

Figure 10. During the yawning display, Hippopotamus amphibius Linnaeus, 1758, opens the mouth extremely widely making a right angle between the cranium and the neck, and between the upper and lower jaws (left image skull and mandible in gape position, right image in the flesh). The live hippo on the left of the sparring pair has its jaws opened about $5-10^{\circ}$ wider than in the mounted skull and mandible.

The combination of the word potamus (Greek for river) in the generic name Merycopotamus - with its repetition in Hippopotamus - and the word dissimilis for the species, epitomises the ambivalence that has characterised interpretations of the relationship between these two taxa for over a century and a half, alternatively approaching Merycopotamus to Hippopotamus, or distancing it from it. In parallel with this phylogenetic ambivalence there has been a chronological one, those authors who approach the two genera to each other demanding a Late Miocene of Pliocene descendence of hippos from anthracotheres (Owen, 1845; Lydekker, 1876, 1883; Matthew, 1934; Boisserie et al., 2005a, 2005b) whilst those who distance the two genera from each other envisage a much more ancient dichotomy (Kowalevsky, 1873, 1874; Stehlin, 1899-1900, 1908; Pearson, 1927, 1929). The tension between early divergence and late divergence has been ever present in the study of hippo-anthracothere relationships, spiced with divergent interpretations about the polarity of the morphological characters examined.

But were the early morphological observations valid? In some instances they were, but in others they were not. For instance, Falconer \& Cautley (1836) wrote that in Hippopotamus dissimilis the cross section of the lower canine was «pear-shaped» as in Hippopotamus sivalensis Falconer \& Cautley, 1836, which strengthened their opinion that the species dissimilis was a kind of Hippopotamus. But examination of the sections of lower canines of these two species reveals that they are not the same. Hippopotamus has canines that are D-shaped, with the upright of the D (the lingual surface) concave (sometimes described as reniform or kidney-shaped). Furthermore the dentine in hippo canines is hemicentrically organised (in section looking like semi-circular onion rings, joined along a slightly curved junction between the buccal and lingual halves) (Fig. 13) and the pulp cavity is narrow except at the growing extremity. In Merycopotamus, in contrast, the lower canine section is ovoid with a distal crest, has no concavity on the lingual aspect, the dentine is massive, and the pulp cavity invades the tooth further than it does in Hippopotamus, and there is no subdivision between buccal and lingual halves. On account of their internal structure, lower canines of hippos tend to split longitudinally when they become desiccated, whereas those of Merycopotamus and other anthracotheres do not.

\section{Kowalevsky}

Kowalevsky $(1873,1874)$ published two monographs on the Anthracotheriidae, in which he made extensive comparisons of their dental, cranial and post-cranial anatomy with those of other artiodactyls. He did not enter into much detail about hippopotamid origins because he considered that the family belonged to a separate «suborder» [Paridigitata bunodonta (Suina)] from anthracotheres [Paridigitata selenodonta] and was therefore of peripheral interest to the focus of his research. In his second monograph (Kowalevsky, 1874, chart opposite p. 152) he postulated a dichotomy among primitive artiodactyls at the base of the 

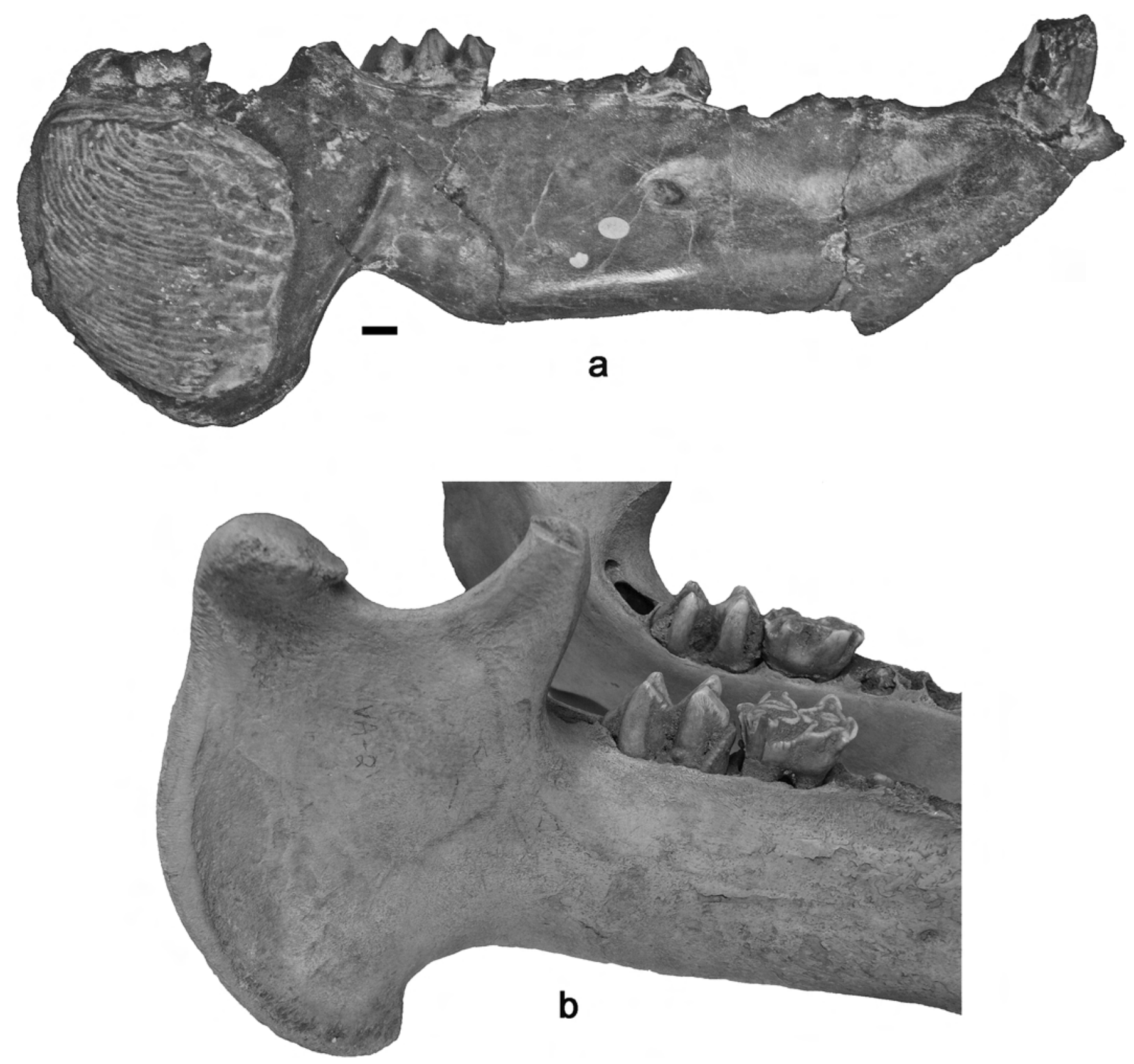

Figure 11. Mandibles of (a) Merycopotamus dissimilis (Falconer \& Cautley, 1836) showing the notch in the base of the ramus anterior to the descending plate and a well developed ridge delimiting the masseteric fossa, and (b) Hippopotamus madagascariensis Guldberg, 1883, showing absence of notch at the base of the ramus in front of the descending plate and the absence of a pre-masseteric ridge on the lateral aspect of the jaw (scale: $10 \mathrm{~mm}$ ).

Eocene, giving rise to these two «suborders». Note that at the time of his study Kowalevsky (1874) considered that the Eocene immediately succeeded the Cretaceous and that the order Paridigitata (ie Artiodactyla) originated during the Cretaceous. The Oligocene had not been recognised by the time of his work, so in his chart the Eocene is followed directly by the Miocene. His phylogenetic schema (Fig. 1) was soon criticised by Lydekker (1883) who preferred a much closer relationship between anthracotheres and hippopotamids, with the dichotomy envisaged as occurring during the Late Miocene.

It should also be noted that Kowalevsky (1873, Pl. 7) was among the first scientists to record that the metapodials of Choeromorus Gervais, 1848, from the Middle Miocene of Sansan, France, (his Choerotherium Lartet, 1851, for a while also known as Taucanamo Simpson, 1945) did not possess a ridge on the anterior aspect of the distal epiphysis. Kowalevsky (1874) accepted the status of the Pal- 


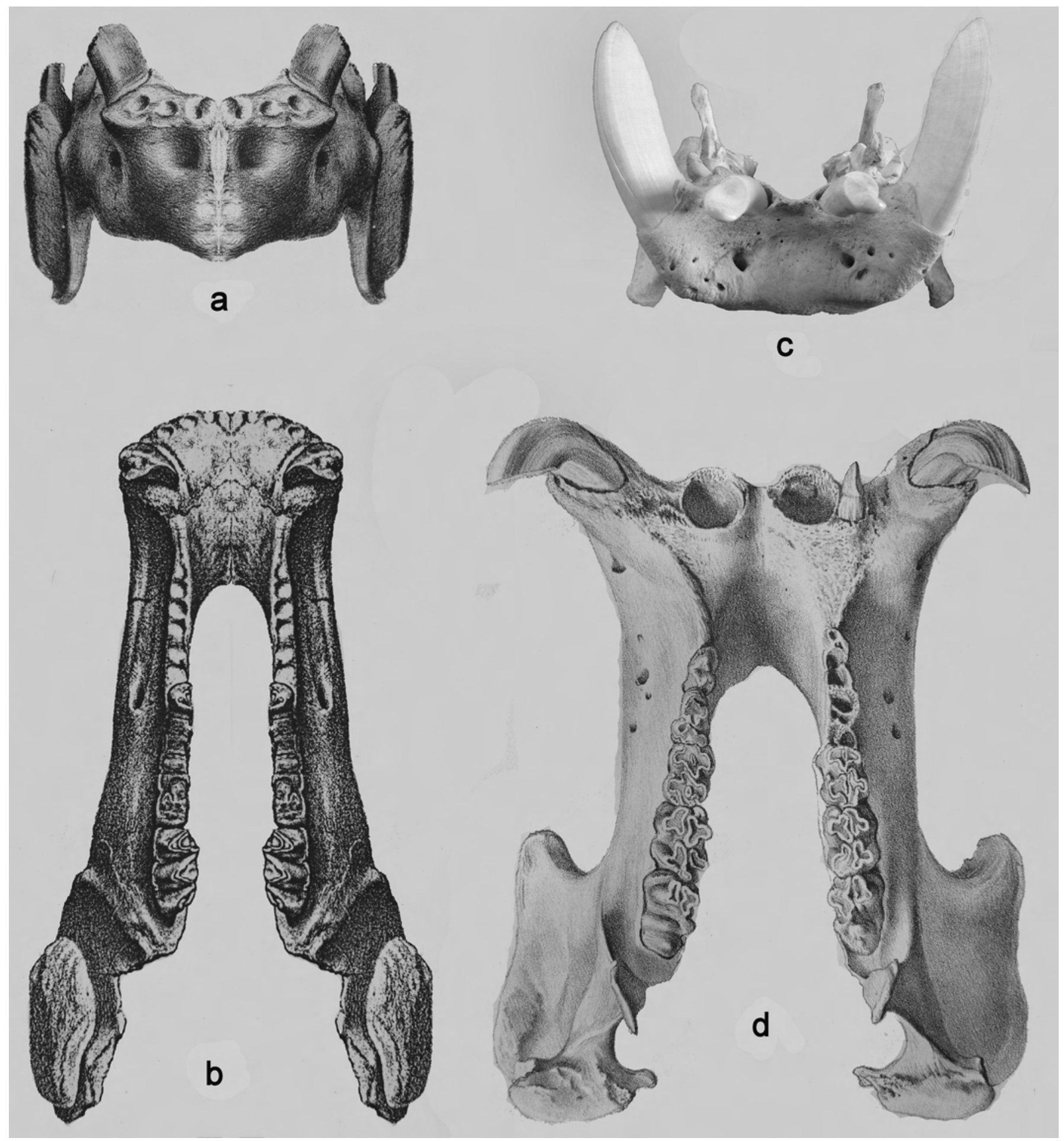

Figure 12. Anterior and dorsal views of mandibles of $(\mathrm{a}, \mathrm{b})$ Merycopotamus dissimilis (Falconer \& Cautley, 1836) showing the vertical orientation of the descending plate (modified from Falconer \& Cautley, 1848), (c) anterior view of mandible of Choeropsis liberiensis (Morton, 1849) and (d) dorsal view of mandible showing the flared orientation in Hippopotamus amphibius Linnaeus, 1758, (a) and (b) modified from Falconer \& Cautley, 1848, (d) modified from de Blainville, 1846) (not to scale).

aeochoerus Pomel, 1847, fossils from St-Gérand-le-Puy, France, unaware that some of the fossils belonged to Hyotherium. Thus the metapodials with a strongly developed ridge on the anterior aspect of the distal epiphysis that he attributed to Palaeochoerus, belong in fact to Hyotherium. This generic misattribution, like that of the skull 


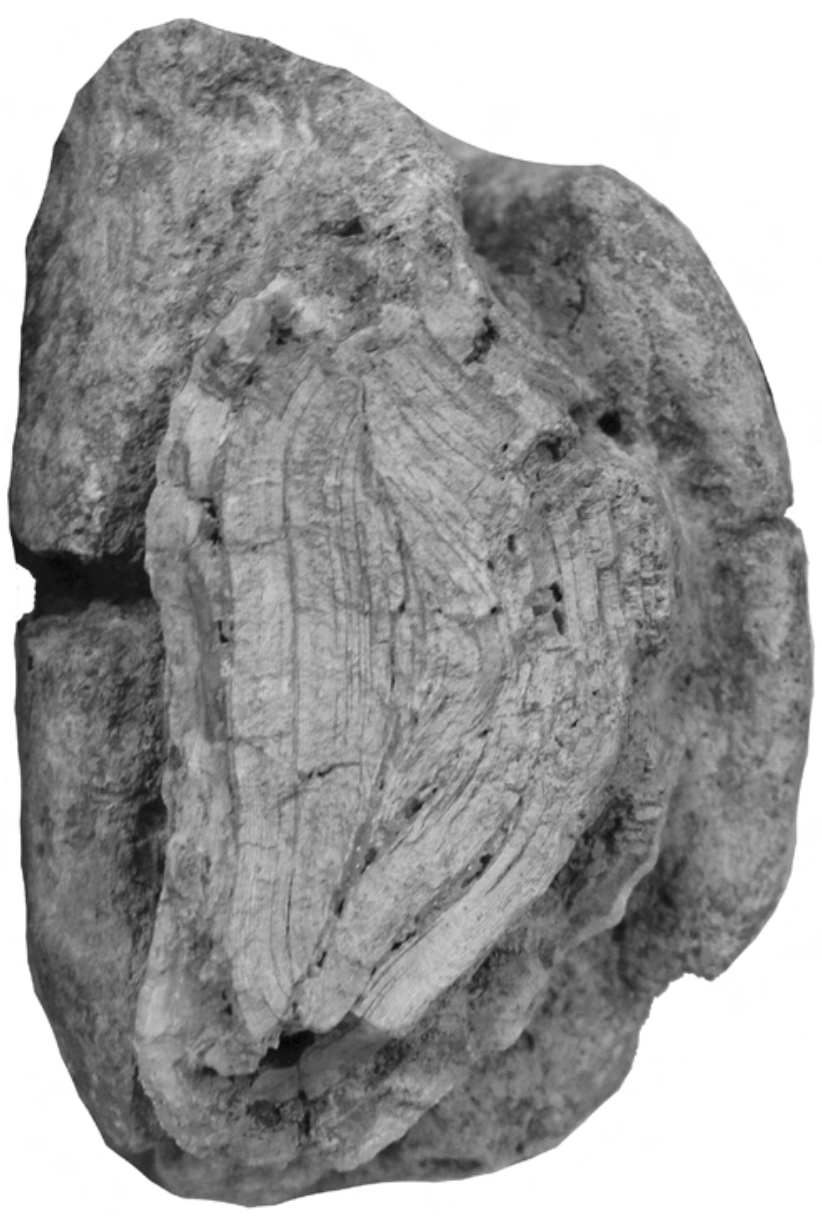

a

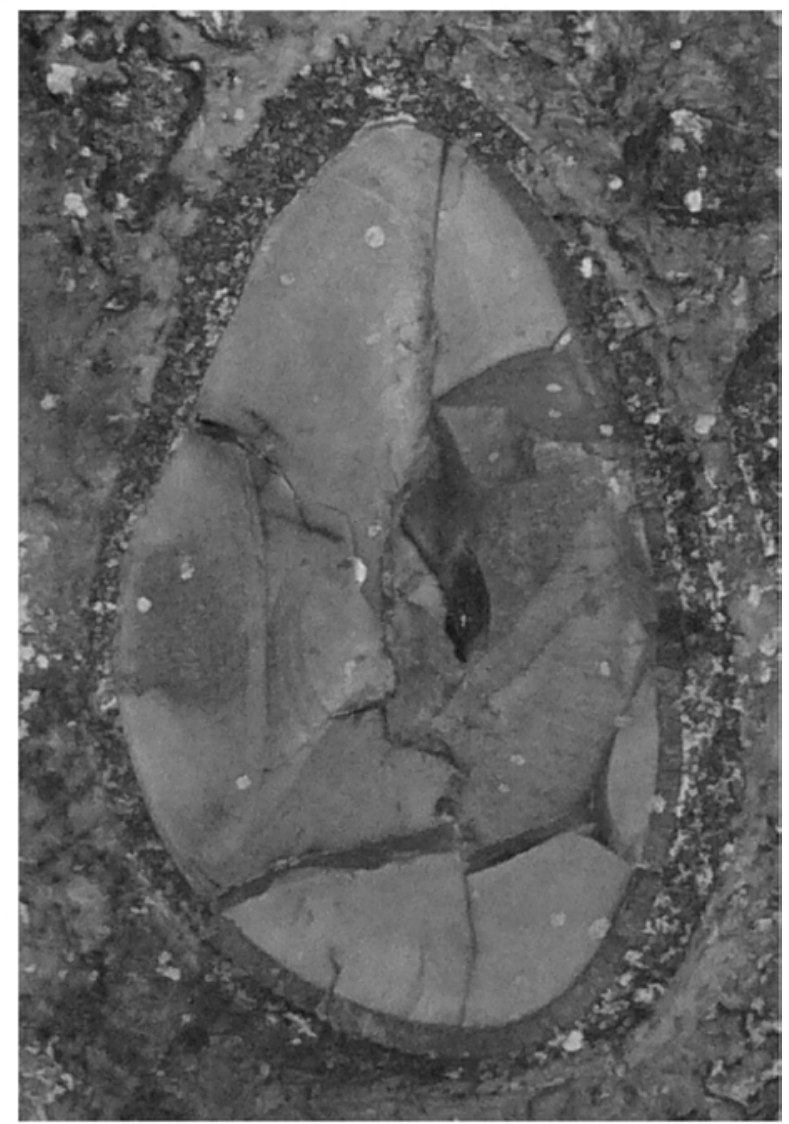

b

Figure 13. Transverse sections through lower canines of (a) Hippopotamus major Cuvier, 1804, Palermo, Italy, and (b) Merycopotamus dissimilis (Falconer \& Cautley, 1836). Note the hemicentric arrangement of the dentine in the hippo canine and the distinct curved junction between the buccal and lingual halves of the tooth in the hippo, and the massive dentine in Merycopotamus (not to scale).

of the same species (Pearson, 1927; Viret, 1961) greatly influenced interpretations of the Early Miocene suoids of Europe for more than a century (Ginsburg, 1974) and has caused an inordinate amount of confusion. Recent interpretations of the phylogenetic relationships of hippopotamids and anthracotheres (Boisserie et al., 2005a, 2005b) are affected by this misidentification.

In his 1874 paper, Kowalevsky depicted a reconstruction of the skeleton of Anthracotherium magnum Cuvier, 1822, based on fossils from La Rochette (Fig. 7). This drawing is interesting in that it shows limb proportions and thorax depth that differ markedly from those of hippopotamids. In hippos, the humerus does not emerge beyond the deep barrel-shaped thoracic mass, but is enveloped inside the thick skin that covers the body, being part of the streamlining adaptation of the animal. When in the water hippos expose only the distal half of the radio-ulna, wrist and foot outside the barrel-like body mass, thereby reducing to a minimum the effect of drag due to limb ex- posure. In the anthracotheriine Anthracotherium magnum the humerus extends clearly beneath the thoracic cage, as in suids, to such an extent that most of the humerus is visible outside the thoracic mass and when in water, it and the rest of the forelimb would have presented a large surface area with a consequently large coefficient of drag. The bothriodontine Elomeryx borbonicus (Gervais, 1852) has a similar long-limbed and slender rib cage aspect to its body plan (Geais, 1934).

\section{Lydekker}

Richard Lydekker wrote extensively on Siwalik mammals, in particular the artiodactyls. He was especially interested in the suprageneric relationships of the species that came under his investigation, the end of the 19th Century being a period during which many investigators including Huxley (1871) and Kowalevsky (1873) were research- 
ing such higher taxonomic issues. Nowadays we would describe the debate in terms of questioning whether the Artiodactyla are monophyletic or paraphyletic. Lydekker focussed in particular on the subdivision of the Artiodactyla into non-ruminating and ruminating animals. He evidently considered, like many of his contemporaries, that the former equate with the bunodont types and the latter with selenodont types, although he stressed that extinct forms were sometimes intermediate in dental morphology and thus could not be easily classified into one or other of the groups.

The comprehensive collection of anthracotheres that he had available, in particular that of Merycopotamus dissimilis from the Plio-Pleistocene Upper Siwaliks of India, posed particular problems to Lydekker, on account of the presence of what he took to be hippopotamoid features in the skull, mandible and dentition indicating to him the possibility of links to Hippopotamidae, yet showing many features that differed fundamentally from hippos, not only in the cranium, but also in the dentition and post-cranium (Table 1). His writings on the subject of the affinities of Merycopotamus and its relationships to Hippopotamus show a curious ambivalence, with the text sometimes highlighting similarities to hippos whereas the tables show Merycopotamus to be an anthracothere, well removed from the hippos, not only at the family level but also at a higher superfamilial or even subordinal level (Bunodontia versus Selenodontia for example) (Table 2).

Lydekker's publications reveal a person struggling to make sense of what we would today refer to as derived or primitive morphology (apomorphies or plesiomorphies respectively) and homology and homoplasy (similarities due respectively to common ancestry or to convergence). To Lydekker $(1876,1877)$ the exaggeratedly descending angle of the mandible in Merycopotamus, for example, represented shared derived morphology found only in Hippopotamus and Merycopotamus among the artiodactyls and thereby denoting cousinship (as he put it) between these two genera. Many subsequent authors such as Colbert (1935) concurred with Lydekker's opinion. In his detailed description of the osteology of Merycopotamus, Lyddeker (1876) compared the fossil Merycopotamus remains with extant Hippopotamus and Sus Linnaeus, 1758, and barely mentioned other artiodactyls. Colbert (1935) made a similar restricted comparison (Merycopotamus, Hippopotamus, and the suid Conohyus Pilgrim, 1925) and came to a similar conclusion, the sample analysed almost guaranteeing the result. As a consequence of the sample choice, Merycopotamus appeared to Lydekker to have greater affinities with hippos than with suids from which he was "inclined to place the genus in the family Hippopotamidae, forming a link between that and the Anthracotheridae (sic)". In subsequent publications he noted that the words "Hippopotamidae" and "Anthracotheridae" had been transposed in the 1876 paper, completely altering the conclusion by removing Merycopotamus from Hippopotamidae and classifying it in Anthracotheriidae, but being more consistent with his subsequent writings. The suprageneric categories that Lydekker was employing were at the time a subject of active debate, with very little consensus emerging about how to arrange the artiodactyls into subordinal categories, and this shows clearly in Lydekker's own results.

Superficial resemblances between Hippopotamus mandibles and those of Merycopotamus were noted as soon as fossils of the latter genus were discovered (Falconer $\&$ Cautley, 1836) which is why the discoverers initially classified the remains as Hippopotamus dissimilis. Lydekker (1876) was so impressed by the descending angle of the jaw that he repeatedly remarked on its significance, taking it to be an apomorphy shared by the two genera. However, he made a peculiar error (Lydekker, 1883) when describing the 'angle' in the mandibles of Hippopotamus and Merycopotamus, which he wrote was, in both genera, «produced into a large plate, preceded by a deep notch in the inferior border of the horizontal ramus». This notch is present in Merycopotamus (Fig. 11a) but not in Hippopotamus in which the jaw deepens beneath the $\mathrm{m} / 3$ (Fig. 11b). Furthermore, the descending plate in Merycopotamus is oriented almost vertically, not splayed out laterally as in Hippopotamus (Fig. 12) in which it is part of the adaptation for opening the jaw extremely widely during ritual displays. In Merycopotamus there is a well defined, almost rectilinear, obliquely descending ridge of bone on the lateral aspect of the mandible that is in line with the leading edge of the descending plate and its upper end points towards the middle of the $\mathrm{m} / 3$ (Falconer \& Cautley, 1836). Superiorly this ridge, which marks the anterior margin of the insertion of the masseter, terminates in the upper third of the ramus, the area above it being flat (Fig. 11a). In hippos there is no corresponding ridge of bone, the jaw being smooth in the equivalent region (Fig. 11b). These differences reveal that the derived structures of the angular region of the mandible in Merycopotamus and Hippopotamus are not homologous. The resemblances of the descending plate and its surrounding structures in the two genera are superficial, and are due to convergence rather than to commonality of descent.

Despite these rather prominent differences, already evoked by Falconer \& Cautley (1836), Lydekker (1877) evidently considered the similarities in mandibular morphology of hippos and Merycopotamus to be homologous. He wrote that "the very remarkable similarity in the form of the mandible of Hippopotamus and Merycopotamus .... admit that these two genera must have descended from some common ancestor which had a similarly shaped mandible". He mentioned that "no other pig-like animal, either recent or fossil has a similarly shaped lower jaw, though there is a very slight rudiment of the descending process in the American Peccari and Hyopotamus". Because of the supposed homology of the mandibular characters of 


\begin{tabular}{|c|c|c|}
\hline Skeletal Character & Merycopotamus & Hippopotamus \\
\hline Profile of occipital crest to nasals & evenly sloping & evenly sloping \\
\hline Depth of the upper portion of cranium & slight & slight \\
\hline Zygomatic arches & wide & wide \\
\hline Sagittal crest & deep, strong & deep, strong \\
\hline Muzzle & slightly expanded & enormously expanded \\
\hline Orbits & elevated & elevated \\
\hline Orbits & closed posteriorly & closed posteriorly \\
\hline Position of inferior portion of orbit & unusually far forwards (over M1/) & backwards (over M2/) \\
\hline Proximal extremity of nasals & low & high \\
\hline Distal extremity of nasal & acute with re-entering angle & expanded \\
\hline Facial surface of nasals & nearly flat & rounded \\
\hline Facial surface of nasals & at right angles to lateral surface of maxilla & no angle \\
\hline Nasal articulation with premaxilla & small & longer \\
\hline Premaxilla & long & short \\
\hline Naso-maxilla suture & straight & not straight \\
\hline Premaxilla overlap of facial surface of nasals & none & none \\
\hline Foramen for 5th nerve & above P4/ & anteriorly positioned \\
\hline Jugal & continuous with maxilla & overhangs maxilla \\
\hline Maxillary process for articulation with jugal & none & present \\
\hline Lachrymal & elongated & different proportions \\
\hline Lachrymal foramen & single & single \\
\hline Position of lachrymal foramen & close to angle of lachrymal bone & not close to angle of lachrymal bone \\
\hline Frontals in front of orbits & expanded laterally & not expanded laterally \\
\hline Supraorbital foramen & above centre of orbits & above centre of orbits \\
\hline Hinder portion of parietals & greatly longer & short \\
\hline Sagittal crest & long & short \\
\hline Cranial and facial portions of skull & approximately equal & facial part much longer than cranial \\
\hline Temporal fossa & in line with lateral edge of orbit & inside lateral edge of orbit \\
\hline Form of occiput & close to Sus & unlike Sus \\
\hline Occiput breadth to height ratio & less & more \\
\hline Occipital surface of squamosal & more advanced of supraoccipital plane & less advanced of supraocciptal plane \\
\hline Median groove on basi-occiptal & absent & present \\
\hline Tubercles on basi-occiptal & absent & two present \\
\hline Tympanic bulla & larger & smaller \\
\hline Distal extension of palatines & behind M3/ & behind M3/ \\
\hline Upward bend of palato-maxillary suture & rounded & elongated \\
\hline Tooth rows & nearly parallel & diverging anteriorly \\
\hline Glenoid cavity & flat, large & large flat \\
\hline Jugal process bordering glenoid & none & none \\
\hline Posterior extremity of mandible & descending & descending \\
\hline Incisors & small & large \\
\hline Canine position & close to $\mathrm{i} / 3$ in line with molars & outside line of molars \\
\hline Canine section & trihedral & not trihedral \\
\hline Upper canine & no posterior groove & posterior groove present \\
\hline Axis vertebra & long & short \\
\hline Axis rim connecting facets for the atlas & less developed & greater development \\
\hline Axis transverse processes & slightly wider & narrower \\
\hline Femur greater trochanter & high & low \\
\hline Femur greater trochanter & recurved & straighter \\
\hline Femoral head orientation on neck & more nearly perpendicular & not perpendicular \\
\hline Femur digital fossa & deeper & shallower \\
\hline Femur distal trochlea & elongated & short \\
\hline Femur distal trochlea & parallel to long axis of bone & not parallel to long axis of bone \\
\hline Tibia, region between the two articular surfaces & notched & not notched \\
\hline Tibia posterior border of proximal end & notched & not notched \\
\hline Talus breadth/length ratio & $\operatorname{long}(b=1 / 2 \mathrm{l})$ & short $(b=2 / 31)$ \\
\hline Talus trochlea surface for calcaneum & oblong & almost square \\
\hline Talus pit between calcanear and tibial articulations & shallower & deeper \\
\hline Calcaneum & similar & similar \\
\hline Metacarpal distal articulation & similar & similar \\
\hline Foot position relative to line separating 3 rd and 4 th digits & less symmetrical & symmetrical \\
\hline Ist phalanx & similar & similar \\
\hline Humerus greater tuberosity & less developed & more developed \\
\hline Humerus bicipital groove & unusually wide & narrower \\
\hline Humerus bicipital groove & less closed in by bone & more closed in by bone \\
\hline Deltoid ridge & strong & strong \\
\hline Posterior extension of greater tuberosity & more continuous & less continuous \\
\hline Distal humerus ridge on radial half of trochlea & more prominent & less promient \\
\hline Ulnar condyle of humerus & more prominent & less prominent \\
\hline Fusion of radio-ulna & not ankylosed & ankylosed \\
\hline Radius mid-shaft & not contracted & contracted \\
\hline Distal ulna & enlarged & enlarged \\
\hline
\end{tabular}

Table 1. Osteological comparison between Merycopotamus and Hippopotamus summarised from Lydekker (1876) (some of these characters such as orbital closure, are now known to be variable - I have summarised them as Lydekker reported). 
A - Bunodontia

1. Suidae

2. Dicotylidae

Sus, Porcula, Babirusa, Hippohyus (?), Sanitherium (1), Amphichoerus (2), Heterohyus (3),

Choeromorus (4), Potamochoerus, Palaeochoerus (5)

3. Acotherulidae

Dicotyles, Hyotherium (?) (6), Thinohyus, Platygonus

Acotherulum, Leptacotherulum

4. Phacochoeridae (7)

Phacochoerus

5. Entelodontidae

Entelodon, Tetraconodon (8), Achaenodon

6. Hippopotamidae

?

Hippopotamus, Choeropsis

Leptochoerus, Parahyus, Eohyus, Helohyus

B - Selenodontia

a. Pentacuspidati

1. Anthracotheridae (sic)

Anthracotherium, Hyopotamus, Rhagatherium, Choeropotamus, Hemichoerus

(?) 2. Mixtotheriodontidae

Mixtotherium

(?) 3. Diplopidae

b. Tetracuspidati

Diplopus

1. Merycopotamidae

2. Oreodontidae

Merycopotamus, Choeromeryx, Hemimeryx, Sivameryx (9)

c. Anoplotherina

Oreodon, Eporeodon, Agriochoerus, Merycochoerus

1. Anoplotheridae

Anoplotherium, Eurytherium, etc.

(?) II - PACHYSIMIA

Cebochoeridae

Cebochoerus

\section{III - RUMINANTIA}

Notes:

1 Sanitherium is now classified in its own family Sanitheriidae

2. Amphichoerus is no longer considered a suid.

3. Heterohyus is no longer considered a suid.

4. Choeromorus is now classed in Palaeochoeridae (for a while it was called Taucanamo).

5. Palaeochoerus is the type genus of Palaeochoeridae and is not a suid.

6. Hyotherium is now classified in Suidae.

7. Phacochoeridae is a synonym of Suidae. Phacochoerus is a suid.

8. Tetraconodon is now classified as Suidae, being the type genus of the subfamily Tetraconodontinae.

9. Sivameryx is pentacuspidate.

In addition, Lydekker (1877) noted similarities between the upper molars of the giant suid Hippopotamodon and those of Hippopotamus, hence the name of his new genus, which did not figure in his 1883 chart, although he evidently considered it to be allied to the hippos.

These changes affect the context of the comparative arguments of Lydekker outlined above.

Table 2. Lydekker's 1883 classification of the Suina relative to the Pachysimia and Ruminantia.

Hippopotamus and Merycopotamus, Lydekker (1877) was forced to question Kowalevsky's thesis that the Bunodonta separated from the Selenodonta during the Eocene, and he surmised that "the Bunodonta and Selenodonta are more closely connected than Kowalevsky supposes". Furthermore, the selenodont dentition of Merycopotamus indicated to Lydekker that its ancestor "must have been selenodont or hemi-selenodont" and therefore that "Hippopotamus is descended from a selenodont and not a bunodont ancestor" providing "an instance of reversion to an older type".
But countering this explanation in his summary, Lydekker (1877, p. 81) classed the pigs and hippopotamoids as Suina Bunodonta (sic) and the hyopotamoids (ie anthracotheres) and anoplotherioids as Suina Selenodonta (sic).

Table 1 reveals that the morphology of the postcranial skeleton of Merycopotamus is highly divergent from that of Hippopotamus except in the calcaneum, distal end of the metapodials and phalanges, and that the skull and mandible are overall rather different, but with some similar features, and the dentition is highly divergent (seleno- 
dont as opposed to bunodont, as well as in details of tooth position, incisor and canine morphology, etc). To this list should be added that the $\mathrm{p} / 1$ is close to $\mathrm{p} / 2$ in Merycopotamus and well separated from $\mathrm{p} / 2$ in Hippopotamus and that the morphology of the limb bones of Merycopotamus are nearer to those of anthracotheres, whereas those of hippos are far from anthracotheres (Lydekker, 1883).

When Lydekker $(1876,1877,1883)$ was discussing supra-generic relationships he cast aside most of the detailed osteological comparisons that he made between Merycopotamus, Sus and Hippopotamus which showed that in many features Merycopotamus differed fundamentally from Hippopotamus (Table 1) and instead his classificatory decisions were based almost exclusively on the form of the angle of the lower jaw. In 1883, Lydekker's classification shows Merycopotamidae in Selenodontia (Tetracuspidati) well separated from Hippopotamidae which is classed in the Bunodontia, yet in the text in the previous page (Lydekker, 1883, p. 145) he lamented that in the table "the relationship of Hippopotamus to Merycopotamus is not apparent" the former genus being placed nearer to Pachysimia (ie Cebochoeridae) which is closer to Hyotherium (questionably classified in Dicotylidae by Lydekker) and Acotherulum Gervais, 1850 (Acotherulidae) both of which are included in Bunodontia by Lydekker. There is thus a curious ambiguity in Lydekker's writings, alternatively linking Merycopotamus to, and distancing it from, Hippopotamus. This ambiguity is highlighted by the sentence (Lydekker, 1883, p. 166) "The intimate resemblance of the molars (of Merycopotamus) to those of the Anthracotheridae and Oreodontidae leaves, however, little doubt but that the true position of the genus is in immediate juxtaposition to those families: the form of the mandible indicates, on the other hand, a distant cousinship with the hippopotamus".

\section{Stehlin}

Stehlin (1899-1900) considered that the hippo lineage emerged from Eocene Suiformes on the basis of the morphology of the back of the skull and the milk dentition, which reflected that of Choeromorus (not the Middle Miocene Sansan material, but Eocene fossils that are today referred to the Cebochoeridae or at the beginning of the 20th Century to Choeromoridae). He considered that the hippo ancestor would have been of medium size, bunodont, with a distally open orbit, flat skull roof, normal zygomatic arch, moderately elongated extremities and four toes. He stressed that the difficulty with «Choeromorus» resided in insufficient knowledge of Eocene skulls, and the lack of useful Oligocene or Miocene forms, but proposed «possibly at the end of the Eocene, one of the Choeromoridae, nearly related to Acotherulum, found a refuge in the southern continent (ie Africa) where during the Oligocene and
Miocene periods it gradually farther differentiated in the direction of the Hippopotamidae» (translation in Forsyth Major, 1902). Recent support for a choeromorid ancestry of hippos has been published by Theodor \& Foss (2006).

\section{Andrews}

C. W. Andrews (1906) wrote a paper that unduly influenced subsequent research into hippo origins, despite his comments about hippo-anthracothere relationships being based on similarities between a single bone (the pelvis) of each group. Colbert (1935) for instance was greatly impressed with the paper and cited from it in extenso in support of his thesis that hippos descended from anthracotheres. In fact, Andrews (1906, p. 186) restricted his comments to the pelvis, which he noted was of similar construction in Ancodon Pomel, 1847, Brachyodus Depéret, 1895, and Hippopotamus. None of the other bones of Ancodon from the Fayum, Egypt, described by Andrews (1906) resemble in detail those of hippopotami. The few resemblances that there are, are due to the fact that both are suiform artiodactyls. The cranium and dentition of Ancodon gorringei Andrews, 1906 (later put into the genus Brachyodus) and Hippopotamus are entirely divergent as are most of the post-cranial bones (long and slender in Ancodon, short and robust in Hippopotamus).

\section{Joleaud: Depéret}

Joleaud (1920) proposed that the Indian hippo lineage descended from Aprotodon Forster Cooper, 1915, a genus from the Oligocene of Baluchistan, an idea reiterated by Depéret (1921). As it happens, Aprotodon is a rhinocerotid (McKenna \& Bell, 1997; Guérin, pers. comm.).

\section{Pearson}

Pearson $(1927,1929)$ compared the basicranium and otic region of a wide diversity of artiodactyls, making a significant contribution to the understanding of the relationships of the genera to each other. Unfortunately she failed to realise that what she described as a skull of Palaeochoerus from St-Gérand-le-Puy, was in fact a cranium of Hyotherium, a suid. This misattribution in no way detracts from her anatomical analysis of the specimen, but it does affect her conclusions regarding the relationship between «Palaeochoerus» and other artiodactyls. This misattribution has confused many subsequent workers (Boisserie et al., 2005a, 2005b) even though the correct identification was first published in 1974 by Ginsburg, and confirmed by Van der Made (1996, 1997). 
Pearson $(1927,1929)$ who carried out extremely detailed comparisons on many artiodactyls, considered that hippos were most likely descended from Cebochoerus Gervais, 1848 , although she noted several similarities between the skulls of peccaries and hippos. She was adamant that Merycopotamus was radically divergent from Hippopotamus, going to the extent of making a detailed study of the hinder part of the skull of the two genera. This study resulted in Merycopotamus being reclassed as an anthracothere. Where its basicranium and occiput differed from that of other anthracotheres (and in her opinion, it did not differ much) it was not in the direction of Hippopotamus. The cebochoerid hypothesis has taken on renewed interest (Theodor \& Foss, 2006) with the realisation that it and some close relatives possess deciduous dentitions which recall cetacean teeth.

\section{Dietrich}

Dietrich (1928) described the fossil Pleistocene hippopotami from Tanzania, and briefly discussed the origin of the family. He dismissed Joleaud's (1920) derivation of hippos from Aprotodon rather harshly «führt zu phantastischer Absurdität» explaining that the natural sequence of reduction of the incisors would be Hexa - Tetra $-D i$ - A-protodon, which is the opposite of the sequence proposed by Joleaud. Dietrich seems to have been unaware that Aprotodon is in fact a rhinocerotid. He appears to have agreed more or less with Stehlin's (1899-1900, 1908) views on hippo origins, and went on to propose that in its appearance, the ancestor of the hippos would have approximately resembled Tayassu Fischer de Waldheim, 1814, among the living suids (at the time New World peccaries were included in suids by some authors) but he did not venture to identify any possible ancestor.

\section{Matthew}

Matthew (1929b, 1934) wrote of hippo origins «Their derivation has been supposed to be from the anthracotheres, through Merycopotamus. This is quite certainly wrong. They are derived from the Suidae.... The smaller Pleistocene species ... are very suggestively like midTertiary Suidae in construction of molars and premolars. This is especially true of Hyopotamus minutus Blainville, 1847, from Cyprus and Crete collected by Miss Bate, which strongly reminds one of such primitive Suidae as Desmathyus Matthew, 1907, etc. out of the Upper Rosebud and Lower Sheep Creek of the Western United States». Given that Matthew (1934, chart) included in Suidae what we would today classify as palaeochoerids, tayassuids and suids (and possibly cebochoerids as well) and the fact that the Cypriot fossils are now attributed to the genus Hippopotamus, his conclusion is not far from the mark. It requires nuancing, but this is often the case with scientific hypotheses. Matthew (1929a) insisted that postcranial evidence is essential for the proper assessment of relationships between artiodactyl families, but his advice has generally been ignored by subsequent researchers, although two papers published recently (Theodor \& Foss, 2006; Geisler \& Uhen, 2006) included many post-cranial characters, which led to the conclusion that hippos were not the sister-group of anthracotheres.

\section{Geais}

Geais (1934) was able to reconstruct the skeleton of Elomeryx borbonicus (at the time attributed to Brachyodus) on the basis of numerous skeletal parts from St-Henri, near Marseille (Fig. 7). She documented the elongated limb elements of the species and the neck in which the atlas and axis resembled that of the wild boar [Sus scrofa (Linnaeus, 1758)] in general aspect and dimensions. Despite these differences from hippopotamids, she envisaged that the species, which was about the size of a pig, lived like hippos in troops in swampy areas, passing part of the day swimming in water and emerging onto the banks to eat and rest. Although Geais did not specifically address the origins of hippos, her reconstruction of the lifestyle and ecology of Elomeryx borbonicus helped to perpetuate the view that anthracotheres looked, moved and behaved like hippos, despite the differences in their body plan and limb bones.

\section{Colbert}

In his discussion on the origin of the Hippopotamidae, Colbert (1935) put great weight on the form of the mandible. As he described it «In Merycopotamus the symphysis is very heavy and broad, and the angle is produced ventrally in a manner extraordinarily similar to the ventrally produced angle in the Hippopotamidae». However, the symphyseal characters were already shown by Falconer \& Cautley (1836) not to be like those of hippos when they described it as being slender and narrow, so it is somewhat surprising to find Colbert (1935, p. 12) insisting so strongly on their resemblance to those of hippos. It is perhaps due to the fact that he compared only three genera, Merycopotamus, Hippopotamus and a highly derived suid, Conohyus. In this restricted comparison, Merycopotamus does indeed come out more similar to Hippopotamus, but since there are many other suoids that could (and should) have been included in the comparison, then Colbert's analysis [like Lydekker's (1876) one] is inadequate. What is even more surprising is that Colbert (1935, Fig. 3) like Falconer \& Cautley (1847) before him, incorrectly reconstructed the angle in the hippo mandible to look similar to that of Merycopotamus, introducing a rising notch in the ventral 
margin of the ramus immediately anterior to the descending angle, something that does not exist in Recent hippopotami. The rest of his analysis of the skull, dentition and post-cranial skeleton is likewise flawed, and in any case was extremely cursory. It ignored Lydekker's (1876) detailed descriptions and interpretations of the osteology of Merycopotamus, and it did not delve in any detail into Pearson's $(1927,1929)$ work on the basicranium and otic region of the skull, simply dealing with it in a paragraph of 8 lines. Because of the missing taxa and missing data for those taxa included in the study, it was inevitable that Colbert's (1935) study would be compromised. His conclusion that hippos descended from anthracotheres similar to Merycopotamus was thus not a convincing demonstration of hippopotamid phylogenetic relationships.

\section{Lavocat: Viret}

Lavocat (1955) did not enter into much detail about hippo origins, but he did write that «they evidently came from primitive bunodont ungulates». In contrast to Lavocat (1955), Viret (1961) arranged the Hippopotamidae among the Bunoselenodonta, but «without conviction» because, as he explained «It is clear that the method which consists of comparing the ends of branches, and which in addition, are the ends of branches with the same secondary adapation (in the case of Hippopotamus and Merycopotamus) cannot lead to a solution of the problem, the resemblances due to parallelism risking being taken for the expression of relationship» (my translation). The end of the sentence is particularly perspicaceous and prescient.

\section{Leakey: Thenius}

Leakey (1966) did not specifically discuss the question of hippopotamid origins, but reported the discovery of teeth at Fort Ternan, Kenya, with affinities to anthracotheres and hippopotamids, and this led to comments being published by Thenius (1969) and Gaziry (1987a) but both these authors were unaware that the Fort Ternan specimens are in fact the milk teeth of the proboscidean Afrochoerodon Pickford, 2001, and are thus irrelevant to the debate about relationshiops between hippos and anthracotheres. In his paper, Thenius (1969) rejected the close relationship between hippos and Merycopotamus proposed by Colbert (1935) and implied by Leakey (1966) and wrote that the latter genus could not represent the ancestor of hippos.

\section{Pickford}

Pickford (1983) erected the genus Kenyapotamus for two species of extremely primitive hippopotamids from
Maboko (16 Ma), Fort Ternan (13.7 Ma), Ngeringerowa (10-9 Ma), and Nakali (10-9.5 Ma), all sites in Kenya [the genus was subsequently discovered in the Samburu Hills, Kenya (Nakaya et al., 1987; Tsujikawa, 2005)] and at Beglia, Tunisia (Pickford, 1990, 2006). At the time of the study these were by far the earliest known hippopotamids, the previous oldest specimens being about 7 Ma. This prompted Pickford to re-examine the question of hippopotamid origins, partly because it was clear that Kenyapotamus Pickford, 1983, was not only older than Merycopotamus, the previous contendor for ancestry of hippos (Falconer \& Cautley, 1836, 1848; Colbert, 1935) but also because its dentition and talus were radically different from those of Merycopotamus. Examination of the literature and fossil material resulted in the view that hippos were closer to the Suoidea than to any other artiodactyls, as maintained by Pearson $(1927,1929)$ and Matthew (1929b) so Pickford (1983) proposed a descendence from what were known at the time as Old World Tayassuidae (not to be confused with New World Tayassuidae). He realised that hippos did not descend from New World Tayassuidae, counter to the hypothesis of Matthew (1929b) (see above) but proposed that they were derived from a different family of suoids (now known as Palaeochoeridae) that is known mainly from Europe.

It has been appreciated for at least 15 years that the so-called «Old World tayassuids» or as they were sometimes called «doliochoerines» are not closely related to New World Tayassuidae (Pickford \& Morales, 1989) and that they warranted full familial status (Pickford, 1993, Fig. 1, 2). Pending formal publication of this, Pickford (1993) followed Simpson's (1945) classification, as did Ginsburg (1974) Hellmund (1992) and Sudre (1995) but he was clear in his writings that doliochoeres were not particularly close to New World tayassuids, having separated from them during the basal Oligocene or earlier. Alas, application of the word «tayassuid» to the Old World doliochoeres has caused a great deal of confusion, with many authors failing to understand the implications of the qualifying prefix «Old World» in front of it (Randi et al., 1996; Lihoreau \& Boisserie, 2004; Boisserie et al., 2005a, 2005b). In retrospect it is evident that Pickford should at the outset have scrapped the word «tayassuid» when discussing doliochoeres, but because of the historical precedent, the word remained attached to the group until Van der Made's (1996, 1997) papers. The latter papers seem to have escaped the notice of many molecularists and palaeontologists.

It was not until detailed studies of Early Miocene suoids of Europe had been published (Ginsburg, 1974; Hellmund, 1992; Van der Made, 1996, 1997) that it was possible to resolve the systematic issue in a satisfactory way. Until these works were completed, there remained considerable doubt about the familial status of the genus Palaeochoerus and some of the other suoids from the Late Oligocene and Early Miocene. The formal recognition of the separate fa- 
milial status of the «Old World Tayassuidae» took place 22 years after Ginsburg's (1974) breakthrough, in papers published by Van der Made $(1996,1997)$ who resurrected Matthew's (1924) subfamily Palaeochoerinae (Matthew, 1929a) which has priority over Simpson's (1945) Doliochoerinae, but he raised it to family rank on account of the rather fundamental differences in cranial, dental and post-cranial morphology that these suoids have from New World Tayassuidae. He also excluded all the North American genera that Matthew listed in the subfamily.

Pickford (2007) erected the genus Palaeopotamus for hippopotamid material more primitive than Kenyapotamus. The type species is Palaeopotamus ternani (Pickford, 1983) from Fort Ternan (ca $13.7 \mathrm{Ma}$ ) a species which is also present at Maboko (ca $16 \mathrm{Ma}$ ) and Kipsaraman (ca 14.7 Ma). Among Artiodactyla, the teeth of P. ternani are morphologically most similar to those of Palaeochoerus typus (see Hellmund, 1992), but they are appreciably larger.

\section{Gaziry}

Gaziry $(1982,1987 b)$ proposed that hippopotamids and Merycopotamus both descended from Hyoboops Trouessart, 1904 (now known as Sivameryx Lydekker, 1883) but he noted that even if his suggestion were the case, the lineage terminating in Merycopotamus must have separated from that leading to hippos at the time that Hyoboops lived (ie Early Miocene or base of the Middle Miocene). He noted that the latter genus did not possess a downturned mandibular angle, and that therefore the morphological similarities between hippos and Merycopotamus must be due to parallelism, a point he reiterated in a companion paper (Gaziry, 1987a). He envisaged an Asiatic origin of Merycopotamus followed by migration to Africa where it is represented by two species Merycopotamus anisae (Black, 1972) and Merycopotamus petrocchii (Bonarelli, 1947) both of which are now classified in the genus Libycosaurus Bonarelli, 1947 (Pickford, 1991). He envisaged an entirely separate African origin for Hippopotamus. On the basis of the supposed morphological similarities and a supposed common ancestor, he proposed that hippos should be classified as a subfamily of Anthracotheriidae. Alternatively, he argued that if this relationship was not correct, then hippos must have descended from Dichobunidae, citing the analysis of Pilgrimella Dehm \& Oettningen-Spielberg, 1958, from the Eocene of Pakistan.

\section{Gentry \& Hooker}

Gentry \& Hooker (1988) analysed many artiodactyl taxa using a cladistic approach and concluded that the "'Anthracotheriidae' ... become paraphyletic by the nesting of Hippopotamidae within them" and that the "old classic primary division of artiodactyls into Bunodontia and Selenodontia is supported". These authors, unlike Kowalevsky $(1873,1874)$ thus support the inclusion of hippos within the Selenodontia.

\section{Van der Made}

Van der Made (1999) classified the Families Anthracotheriidae and Hippopotamidae in the Superfamily Hippopotamoidea, on the supposed basis that «numerous dental, cranial and postcranial characters, as well as the characters of the soft tissues argue against (Pickford's) model» (that anthracotheres and hippos belong to two separate superfamilies). However, Van der Made (1999) provided no details of the numerous characters, which makes his claim somewhat unsatisfactory, mainly because no soft tissues of anthracotheres are known, and because in anthracotheres and hippos there are manifest differences in cranial, dental and postcranial morphology.

\section{Boisserie, Lihoreau \& Brunet}

Because of the perceived refutation of the «peccary» hypothesis of hippo origins by molecularists, Lihoreau \& Boisserie (2004) and Boisserie et al. (2005a, 2005b) re-examined the question of hippo origins, and came to the conclusion that hippos were most closely related to bothriodontine anthracotheres. They envisaged that hippos descended from bothriodontine anthracotheres (ie the selenodont ones) with either Merycopotamus or the pair Merycopotamus plus Libycosaurus, as the sister group of hippos. They explicitly rejected the tayassuid and cebochoerid hypotheses of hippo origins. However, examination of their analyses reveals several areas of weakness, notably the problems of missing taxa, missing characters among the included taxa and insufficient background knowledge of the Suoidea. Their analyses focussed heavily on the cranium and dentition, the postcranial skeleton being represented only by the talus and the distal end of the metapodials.

Major difficulties emerge from the studies of Boisserie et al. (2005a, 2005b) as they themselves recognised. One is that hippo descendance from bothriodont anthracotheres would imply a «spectacular reversion» of dental morphology. In order to retain this possibility, the authors invoked the concept of «dental plasticity» which is itself somewhat contentious as a hypothesis. Secondly, their hypothesis ignores the many fundamental morphological differences that exist in almost all the bones and teeth of hippos and anthracotheres, even the supposed sister taxa Merycopotamus and Libycosaurus. As Lydekker (1876) Pearson $(1927,1929)$ and others have pointed out, the 
resemblances between hippos and anthracotheres are superficial, whereas detailed examination of their morphology reveals pervasive differences throughout the skeletal and dental systems.

A further difficulty with the research programme of Boisserie et al. (2005a, 2005b) and Boisserie \& Lihoreau (2006) is that they failed to test the palaeochoerid hypothesis (which used to be called the Old World Tayassuidae hypothesis). Admittedly the literature on suoids is somewhat confusing, but it has been known for two decades that the Old World Tayassuidae differed at the family level from the New World Tayssuidae (Pickford, 1993). Once sufficiently detailed studies of European late Oligocene and Early Miocene suoids had been done (Hellmund, 1992) it became clear that their relationships to Tayassuidae (sensu stricto - ie the American forms) was no longer as close as Pearson (1927) and Simpson (1945) thought, but for the time being they continued to be classified in the same family (Hellmund, 1992; Sudre, 1995). Eventually, Van der Made (1996, 1997) resurrected the name Palaeochoeridae (Matthew, 1924) for the European taxa.

Boisserie et al. (2005a, 2005b) did not refer to these developments, and furthermore, used a skull of Hyotherium (a suid) to score the characters for Palaeochoerus. The history of this particular skull and some postcranial remains from the same locality (St-Gérand-le-Puy) is confusing, because for over a century they were attributed to Palaeochoerus (see Kowalevsky, 1873, 1874; Pearson, 1927; Lavocat, 1955; Viret, 1961). However, Ginsburg (1974) realised that they belonged to the genus Hyotherium (see also Van der Made 1996, 1997). Transposing the Palaeochoerus data to Hyotherium in the papers of Boisserie et al. reduces the representation of Palaeochoeridae in their analyses to a single genus, Doliochoerus Filhol, 1882, for which over 22\% of the characters are missing. Examination of real specimens of Palaeochoerus (see Hellmund, 1992) reveals rather divergent scoring of characters, all of which show similarities to hippopotamids. Inclusion of Palaeochoerus and other Palaeochoeridae in the cladistic analysis will certainly result in radically different phylogenies from those proposed by Boisserie et al. (2005a, 2005b) and Boisserie \& Lihoreau (2006).

\section{Theodor \& Foss: Geisler \& Uhen}

Recently, Theodor \& Foss (2006) have noted dental similarities between cebochoerids and whales, which indicates that Stehlin's (1899-1900) and Pearson's (1927, 1929) hypotheses need re-examining in detail, as suggested by Pickford (1989). Theodor \& Foss (2006) and Geisler \& Uhen (2006) concluded that anthracotheres are not closely related to hippopotamids.

\section{DETAILED COMMENTARY ON THE RECENT HYPOTHESIS THAT ANTHRACOTHERIIDAE IS THE SISTER GROUP OF HIPPOPOTAMIDAE}

\section{Systematic problems}

Lihoreau \& Boisserie (2004) and Boisserie et al. (2005a, 2005b) approached the question of hippopotamid origins as a choice between two alternative hypotheses: Anthracotheriidae or Tayassuidae (the cebochoerid hypothesis was mentioned in the latter two papers but was not retained). This summary of the problem is incomplete, because it omits Palaeochoeridae (until recently called Old World Tayassuidae) previously the strongest contendor for ancestral status (Pickford, 1983, 1993; Pickford \& Morales, 1989). In addition to the classificatory and nomenclatural problems, there are numerous difficulties with the character analyses presented by Boisserie et al. (2005a, 2005b).

\section{Taxon choice}

The problem of which taxa to include in any phylogenetic analysis is ever present. Boisserie et al. (2005a) included 32 taxa comprised of three extant peccaries, two fossil peccaries, a single palaeochoerid (listed as a tayassuid), four suids, six hippopotamids, eight anthracotheres, two archaeocetes, a cebochoerid, four ruminants and the genera Archaeotherium Leidy, 1850, and Diacodexis Cope, 1882. Palaeochoeridae did not feature as such in their analysis, which is regrettable since it is the group that Pickford (1983) considered to be the source of the hippopotamids. There are at least 7 genera of Palaeochoeridae known, of which two are represented by parts of the post-cranial skeleton. In contrast Theodor \& Foss (2006) included 51 taxa in their analysis and Geisler \& Uhen (2006) 73 taxa, many of which are not the same as those analysed by Boisserie et al. (2005a) only 14 taxa being common to the Boisserie et al. (2005a) study and one or both of the other two teams.

\section{Character choice}

Lydekker (1876) already showed that the post-cranial skeleton of Merycopotamus was markedly divergent from that of Hippopotamus. In the former the neck, basipodes and metapodials are elongated, whereas in the latter they are short. Most articulations and neighbouring osseous anatomy of the stylopodes and zeugopodes of Merycopotamus differ in morphology from those of Hippopotamus indicating divergent locomotor repertoires. Echoing the publications of Lydekker (1876) and Kowalevsky (1873, 
1874), Matthew (1929a) wrote that post-cranial evidence is essential for the proper assessment of relationships between artiodactyl families. Omission of most of the postcranial skeleton compromises the analyses of Boisserie et al. (2005a, 2005b) as shown recently by Theodor \& Foss (2006) and Geisler \& Uhen (2006).

Because of this, perhaps the most questionable aspect of the Boisserie et al. (2005a, 2005b) studies is the choice of characters used in the analyses. Only 8 out of 80 characters analysed by this team represent post-cranial features, confined to the talus (4 characters), the navicular and cuboid (1 character), the distal end of the metapodial (1 character), and the manual digits (2 characters). The remaining 72 characters were cranial (42 characters), mandibular (5 characters), and dental (25 characters). In their second paper dealing specifically with hippo origins, Boisserie et al. (2005b) included only two postcranial characters (astragalus and lateral digits) among a total of 37 characters. In the same paper 21 characters were scored for cranial morphology, 4 for the mandible and 10 for dental morphology.

\section{Missing data}

Missing data is a fundamental problem in phylogenetic analysis (Gatesy \& O'Leary, 2001) and omission of taxa or of features from most of the skeleton renders hypotheses of relationship open to modification, often quite radically.

Among the anthracotheres analysed by Boisserie et al. (2005a) there were relatively few missing characters (Table 3) whereas in the only palaeochoerid in the analysis almost a quarter of the characters (22.5\%) could not be scored.

\section{Scoring of characters}

Among the characters that could be discerned for $\mathrm{Pal}$ aeochoerus some were scored incorrectly. For example, character 8 in Boisserie et al. (2005a) (position of posterior nasal spine) is described as being in line with or anterior to the rear end of $\mathrm{M} 3 /$, yet in Palaeochoerus typus it is well behind the M3/ (Hellmund, 1992, Pl. 2, Fig. 1). Boisserie et al. (2005a, 2005b) did not score the position of the infra-orbital foramen (character 10) but it is clear from Hellmund (1992, Pl. 1, Fig. C) that it is in an anterior position above the $\mathrm{P} 3 /$ and should be scored as (0). Character 42 (mandibular symphysis fusion) should have been scored as (0) rather than missing. Character (52) (canine dimorphism) should have been scored (1) instead of missing (Hellmund 1992, Pl. 8). Character 58 (lower canine section) in Palaeochoerus is «D-shaped» (Hellmund 1992, Pl. 8) and it should therefore be scored as (1) rather than missing. In my opinion, character 60 (wrinkled or smooth enamel) in Palaeochoerus should have been scored as (0) instead of (1). Character 61 (root of P1/) is clearly doubled in Palaeochoerus (Hellmund, 1992, Pl. 1). Character 62 (form of talon of P3/, should have been scored (0) (Hellmund, 1992, Pl. 1). The P4/ of Palaeochoerus has two main cusps and a small posterior buccal one that is detached from the main cusp. The scoring categories defined by Boisserie et al. does not cater for this morphology of the P4/, but in Palaeochoerus and other palaeochoerids such as Schizochoerus and Choeromorus, it is closer to but not identical to their category (0) than to (1) or (2). Boisserie et al. (2005a, 2005b) scored it as (1) which I consider to be misleading. Character 65 (position of paraconule) was scored as being absent (0) whereas it is present, even if reduced in dimensions, and thus should

\begin{tabular}{|c|c|c|c|c|}
\hline Taxon & $\begin{array}{c}\text { Missing characters } \\
(\text { Total when } \\
\text { complete }=80)\end{array}$ & $\begin{array}{c}\text { Cranial } \\
\text { (Total when complete } \\
=47 \text { ) }\end{array}$ & $\begin{array}{c}\text { Dental } \\
(\text { Total when } \\
\text { complete }=25)\end{array}$ & $\begin{array}{c}\text { Post-cranial } \\
\text { (Total when } \\
\text { complete = 8) }\end{array}$ \\
\hline Doliochoerus & 18 & 15 & 0 & 3 \\
\hline Xenohyus & 50 & 42 & 1 & 8 \\
\hline Kenyapotamus & 59 & 46 & 8 & 5 \\
\hline Palaeochoerus* & 22 & 9 & 5 & 8 \\
\hline Libycosaurus & 2 & 2 & 0 & 0 \\
\hline Merycopotamus & 1 & 1 & 0 & 0 \\
\hline Anthracokeryx & 7 & 3 & 0 & 4 \\
\hline Microbunodon & 2 & 1 & 0 & 1 \\
\hline Elomeryx & 5 & 2 & 0 & 3 \\
\hline Brachyodus & 5 & 3 & 2 & 0 \\
\hline
\end{tabular}

* All the characters scored for Palaeochoerus refer in fact to the suid Hyotherium.

Table 3. Missing characters in analyses of Suiformes by Boisserie et al. (2005a). 
have been scored as (1). Finally as concerns the dentition, the pentacone of M3/ is absent in Palaeochoerus, not present as scored by Boisserie et al. (2005a). Boisserie et al. (2005a, 2005b) did not score any of the postcranial characters for Palaeochoerus.

These contradictions and omissions led me to search for the reason why my assessment of the morphology of Palaeochoerus is so divergent from that of Boisserie et al. (2005a, 2005b). It transpires that they based their determinations on cranial remains published by Pearson (1927) unaware that the said material belongs to the suid Hyotherium (see Ginsburg, 1974; Van der Made, 1996).

The only Palaeochoeridae included in the analysis by Boisserie et al. (2005a, 2005b) was Doliochoerus quercyi Filhol, 1882, some of the characters of which need nuancing. For example, the short gap of $3 \mathrm{~mm}$ between the lower canine and the anterior premolar in Doliochoerus is not the same order of magnitude as the diastema in Tayassuidae (Dechaseaux, 1959) and in my opinion should be scored differently from the simple «absent» or «present» categories used by Boisserie et al. (2005a). Four other characters (wrinkling of the cheek tooth enamel, the number of cusps in $\mathrm{P} 4 /$, the quantity of roots in $\mathrm{P} 4 /$ and the presence or absence of a paraconule in the upper molars) need to be reassessed. Apart from that, the only postcranial bone of Doliochoerus analysed was the talus (four characters scored).

\section{Cranial evidence}

Boisserie et al. (2005a, character 18; 2005b, character 8) like Lydekker $(1876,1877,1883)$ before them, were impressed by the superficial similarities between parts of the skulls of some anthracotheres, such as Libycosaurus and Merycopotamus on the one hand and those of Hippopotamus on the other. In particular they focussed on the elevation of the upper margin of the orbits above the dorsal profile of the skull, and concluded that this represented shared derived morphology denoting a close phylogenetic relationship between the two families. Boisserie (2005, Fig. 8 ) however, wrote that the same character was derived independently in three different lineages of hippopotamines due to convergence. There is therefore a contradiction between conclusions reached in successive publications by Boisserie (2005) and Boisserie et al. (2005a, 2005b). For elevated orbits to be convergently derived in distinct lineages of hippos, then the ancestors must have had low orbits, and this is indeed the case, both Archaeopotamus Boisserie, 2005, and Saotherium Boisserie, 2005, among the fossils and Choeropsis Leidy, 1853, among the extant hippopotamids having non-projecting orbits. In this case the fact that some hippos and some anthracotheres have elevated orbits, means that this condition must be due to convergence, and is not due to shared ancestry between anthracotheres and hippos. Apart from this, the orbits in Libycosaurus are not particularly strongly elevated, and their form is different from that of hippos.

Lihoreau (2003, Fig. I.57B, I.69B) recorded an unusual orbital morphology in Libycosaurus, with the inferior post-orbital process issuing from the squamosal. This inhabitual construction is reported to occur in two species from Chad, Libycosaurus petrocchii (Bonarelli, 1947) and Libycosaurus sp. nov. In contrast, in hippos this process rises from the jugal and the squamosal does not participate in the construction of the orbital margin (Frechkop, 1955). If correctly reported, then the squamosal morphology of Libycosaurus distances it from all other artiodactyls.

Boisserie et al. (2005a, 2005b) proposed that the anthracothere pair Libycosaurus and Merycopotamus formed a clade which was the sister-group of hippos. The supposed close relationship between Merycopotamus and hippos harks back to the work of Colbert (1935) and his predecessors (Falconer \& Cautley, 1848; Lydekker, 1876, $1877,1883)$ who saw in Merycopotamus a close relationship to hippos. However, in 1929, Pearson had already shown that the basicrania of Merycopotamus and Hippopotamus were not similar to each other, particularly in the form and position of the glenoid and surrounding structures, nor in the occipital region. She pointed out when discussing the basicranium and occiput «The hinder region of the skull of Merycopotamus shows only slight differences from that of all anthracotheres, and these differences are not in the direction of Hippopotamus». This is a fairly clear statement that distances the hippos from the anthracotheres, including Merycopotamus. As far as I can judge from the morphology of the basicranium and occiput of Libycosaurus anisae (Black, 1972) (Pickford, 2006) it is also a typical anthracothere, and does not approach the morphology of hippos. This is confirmed by examination of the dorsal aspect of the skulls. In anthracotheres the braincase is elongated and endowed with a long sagittal crest which curves ventrally as it approaches the occipital, whereas in hippos the braincase is shortened and the short sagittal crest bends upwards as it approaches the occiput (Fig. 14). The latter morphology is functionally related to the ritualised contests that hippos practice, in which they raise the head vertically, at the same time that they open their mouths wide to expose the incisors, canines and pink tissues within the mouth. It is unlikely that Libycosaurus or any other anthracothere could extend their heads so far backwards over the neck as do hippos.

The sagittal crest in Libycosaurus is antero-posteriorly elongated (Pickford, 2006) whereas in Choeropsis it is short and in Hippopotamus remarkably so. Palaeochoeridae such as Palaeochoerus from St-Gerand-le-Puy and Choeromorus from Sansan that could be scored for this morphology are similar to Hippopotamus. Sagittal crest morphology thus supports the palaeochoerid hypothesis at the expense of the anthracothere one. 


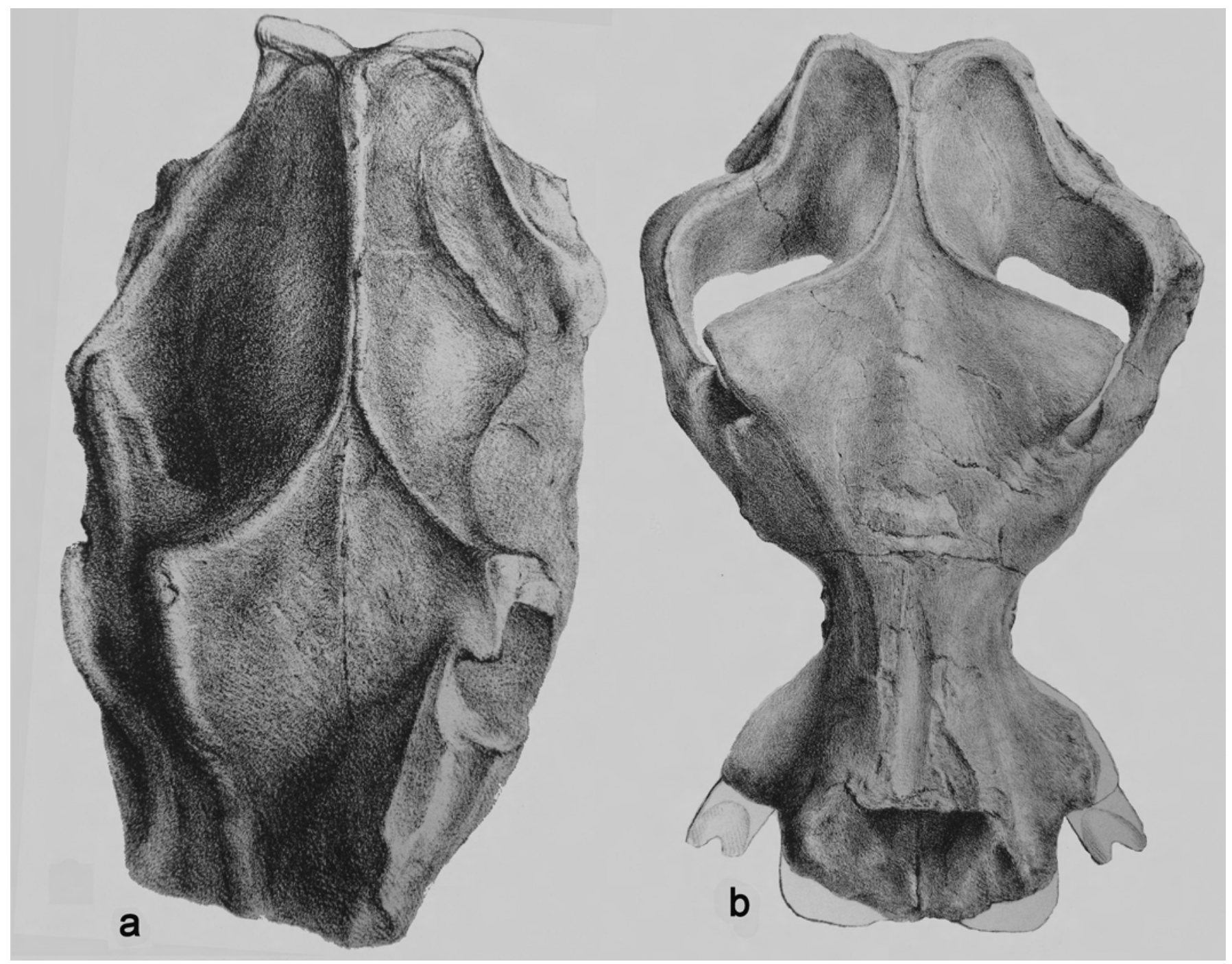

Figure 14. Comparison of sagittal crest morphology in (a) Merycopotamus Falconer \& Cautley, 1848, and (b) Hippopotamus Linnaeus, 1758 (modified from Falconer \& Cautley, 1848). Anthracotheres are klinorhynch and have elongated crests, whereas hippos are airorhynch and as a result have shortened crests (not to scale).

Linked to the orientation of the sagittal crest is the orientation of the basicranium, both being related to the way that the splanchnocranium is hafted onto the neurocranium. Hippos, like suids and palaeochoerids, are airorhynch, with the splanchnocranium rotated dorsally with respect to the brain case, and as a result the basicranium is entirely above the plane of the molars. In anthracotheres in general and bothriodonts such as Merycopotamus and Libycosaurus in particular, the opposite is the case, with the splanchnocranium rotated ventrally with respect to the brain case, with the result that the basicranium is beneath the occlusal plane of the molars. Anthracotheres are therefore klinorhynch.

Because hippos are airorhynch and anthracotheres are not, the shape of the squamosal is quite different in the two groups (Fig. 15). In hippos the zygomatic process of the squamosal is bent dorsally rather sharply, imparting a
V-shaped outline to the upper profile of the bone in lateral view (Frechkop, 1955) whereas in anthracotheres the arch curves gently upwards towards the distal base of the orbit (Lihoreau, 2003) and is thus of an open C-shape.

The splanchnocranium of Libycosaurus is marked by two structures that do not occur in hippopotamids, the presence of a facial tuberosity separated from the facial crest, and the presence of an extensive canine fossa (Lihoreau, 2003, Fig. I.57B). Furthermore, the infraorbital foramen in Libycosaurus is located far anterior from the facial crest of the jugal, with the facial tuberosity interposed between the two elements, whereas in hippos it is immediately in front of the anterior termination of the facial crest. In addition, the facial crest in Libycosaurus rises steeply (ca $45^{\circ}$ to the tooth row) from distal to proximal, whereas in hippos it is at a shallower angle (ca $30^{\circ}$ to the tooth row) (Fig. 15). 

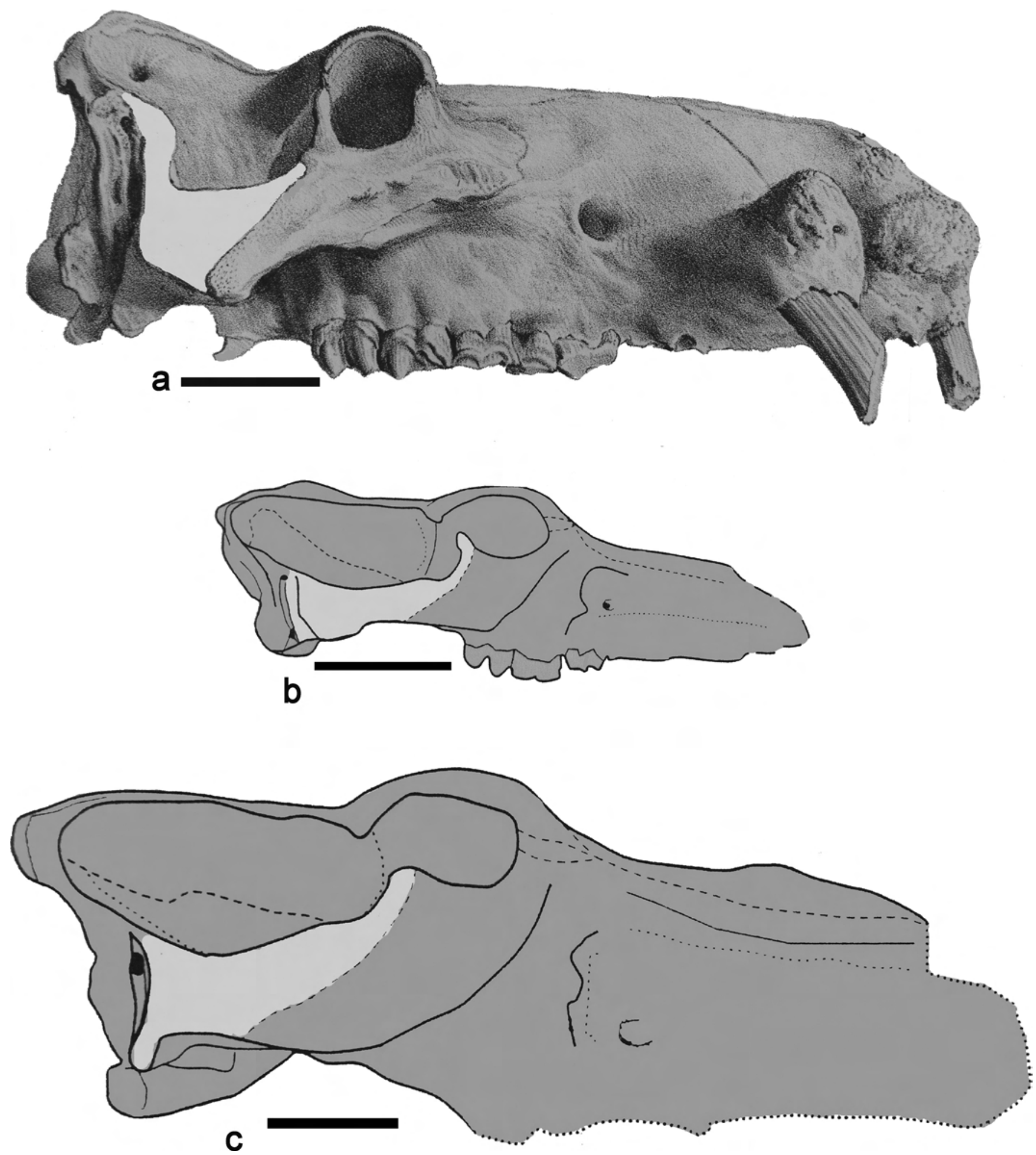

Figure 15. Squamosal and facial morphology in (a) Hippopotamus Linnaeus, 1758 (from Blainville, 1847) and (b, c) two species of Libycosaurus Bonarelli, 1947 (modified from Lihoreau, 2003). The squamosal morphology (light grey) reported in Libycosaurus is unique among artiodactyls, this bone participating in the orbital margin. In hippos the squamosal is deeply recurved (reflecting the airorhynch hafting of the splanchnocranium onto the neurocranium) whereas in anthracotheres its shape is not markedly different from that of other artiodactyls. The morphology of the maxillary root of the zygomatic arch and the absence of a facial tubercle distance the hippo from Libycosaurus (scale for Libycosaurus: $10 \mathrm{~cm}$ ). 
In palatal view, Libycosaurus has a deep channel in the palate extending from the anterior premolar where it is shallow, towards the premaxillae deepening considerably as it goes (Pickford, 1991). This channel is bordered each side by sharp, curved crests of bone, the alveolar ridges, that extend between the anterior premolar and the disto-medial base of the canine jugum (Fig. 16). Proximal to the anterior cheek tooth, the ridges converge towards each other before diverging towards the canine bases. In hippos in contrast, the palatal depression (character 6 in Boisserie et al., 2005a) is considerably shallower, does not deepen anteriorly to any great extent and is not bordered by sharp, incurved alveolar marginal crests (Fig. 16). These depressions are therefore not homologous, and they should not be scored in the same way. Indeed the morphology of this part of the snout in hippos and Libycosaurus is so divergent that it distances the two from each other, rather than approaching them together as suggested by Boisserie \& Lihoreau (2006).

In artiodactyls in general the palatine foramen is located opposite the molars at the contact of the palatine bone with the maxilla. The greater palatine artery and the palatine nerve emerge from this foramen (Sisson \& Grossman, 1953). In hippos and peccaries the bony opening for this ar- tery and nerve is considerably further forwards, the palatine canal being «buried» within the maxilla, but with abundant small connections to the surface along its route (Pickford, 1983). According to Boisserie \& Lihoreau (2006) this is clearly a derived morphology among the artiodactyls, which agrees with Pickford's (1983) assessment of the character. However, according to Boisserie \& Lihoreau (2006) only Libycosaurus among the anthracotheres possesses such an anterior opening (described as an intercanine palatine groove, not to be confused with the intercanine palatal depression) but in the matrix of characters a few other anthracotheres are scored as possessing the same morphology. Even though the morphology is clearly derived within an artiodactyl context the question is, is its presence in hippos and Libycosaurus a synapomorphy or not ? The major differences in the morphology of the palate between the canines and premolars of hippos and Libycosaurus suggests that it is most likely a convergence, and is not homologous.

In basicranial view, the paroccipital process of the exoccipital in hippos is short and is directed obliquely postero-ventrally. The medial edge is in line with the lateral edge of the occipital condyles and in posterior view the two processes are almost parallel to each other. In Libyco-
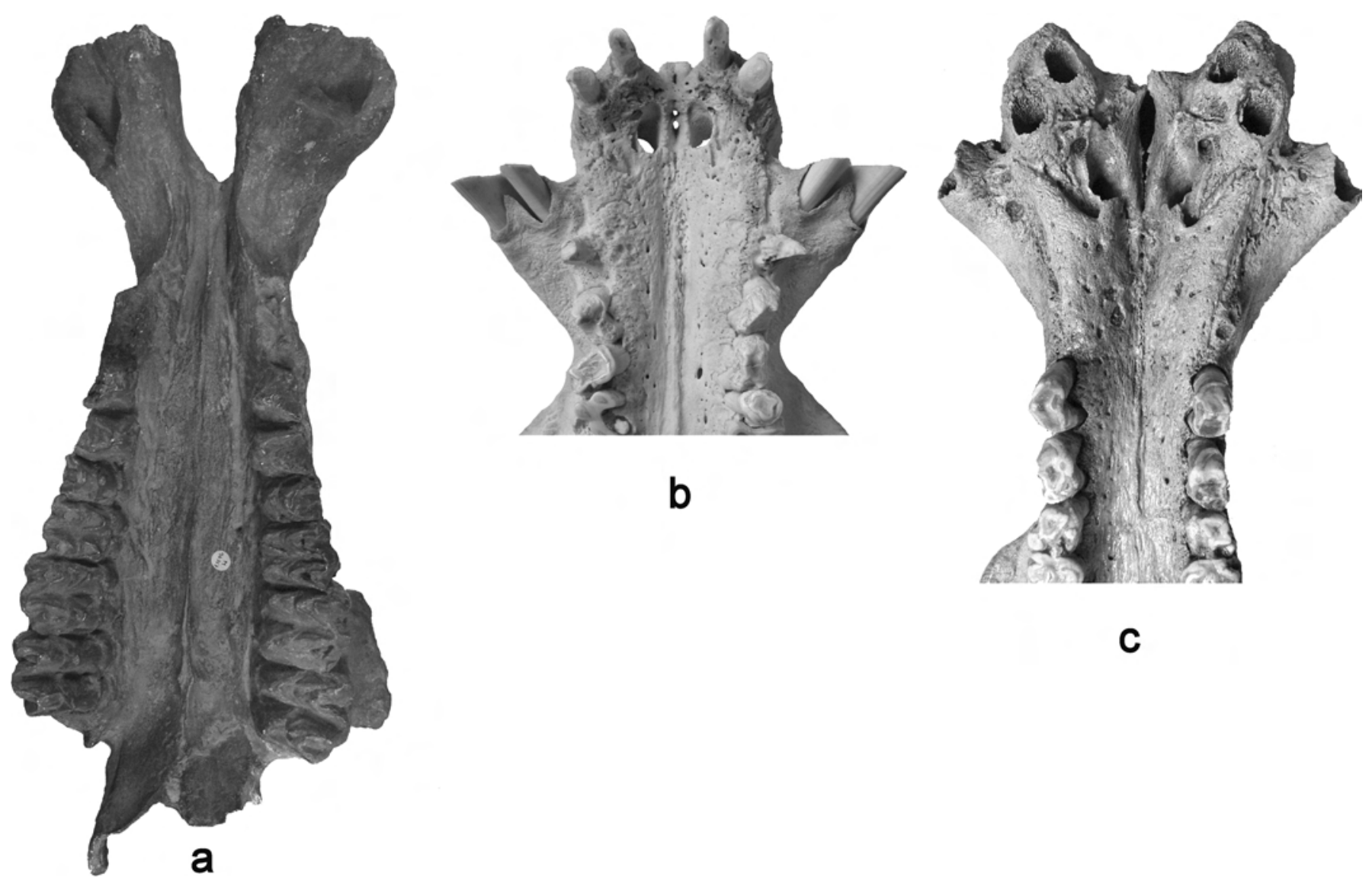

Figure 16. Morphology of the anterior portion of the palate in (a) Libycosaurus Bonarelli, 1947, (b) Choeropsis Leidy, 1853, and (c) Hippopotamus Linnaeus, 1758. In the anthracothere the morphology of the palate between the canines and anterior premolars is completely different from the pattern expressed in hippos (not to scale). 
saurus in contrast, the paroccipital processes (mastoid apophysis of the exoccipital in Lihoreau, 2003) are longer and terminate lateral to the occipital condyles, and they appear to diverge from each other at a marked angle (Lihoreau, 2003, Fig. I.58B, C).

The glenoid fossa in hippos is interrupted laterally by the lateral glenoid tuberosity, a low, roughened swelling of bone that extends about $1 / 3$ of the latero-medial extent of the glenoid surface, separating the articular surface from the zygomatic process. As a result, the glenoid surface descends slightly ventrally towards its lateral extremity. In Libycosaurus, in contrast, there is no tuberosity, but a smooth transition from the articular surface into the zygomatic process, and the lateral extremity curves gently dorsally. Furthermore, in hippos, the retro-glenoid process is restricted to the inner $1 / 3$ of the extent of the glenoid surface and it faces somewhat antero-laterally, being interposed between the glenoid articulation and the posterior part of the tympanic bulla. In Libycosaurus, the retro-glenoid process is appreciably broader medio-laterally, extending over more than half the extent of the glenoid surface, and it faces more anteriorly. It is more laterally positioned compared with hippopotamids, its medial root being lateral to the tympanic bulla, whereas in hippos it overlaps about $1 / 3$ of the bulla. Another point that needs to be made is the extremely posterior position of the glenoid articulation in hippos. In lateral view, the retro-glenoid process terminates behind much of the nuchal plane, whereas in anthracotheres it is positioned further anteriorly. In Choeropsis it is slightly further forwards than in Hippopotamus, but not as much as in anthracotheres. The differences between the basicrania of Merycopotamus and Hippopotamus were dealt with in detail by Pearson (1929) (Fig. 17).

In anthracotheres the tympanohyal pit is located anterior from the stylomastoid foramen, within the same depression between the tympanic bulla and the post-tympanic process of the squamosal. In hippos in contrast, the tympanohyal pit is separated from the stylomastoid foramen and is lateral and slightly posterior from it.

\section{Mandibular evidence}

Boisserie et al. (2005b) state that Pickford (1983) made two errors concerning mandibular fusion in anthracotheres and hippos. What the latter palaeontologist wrote was that
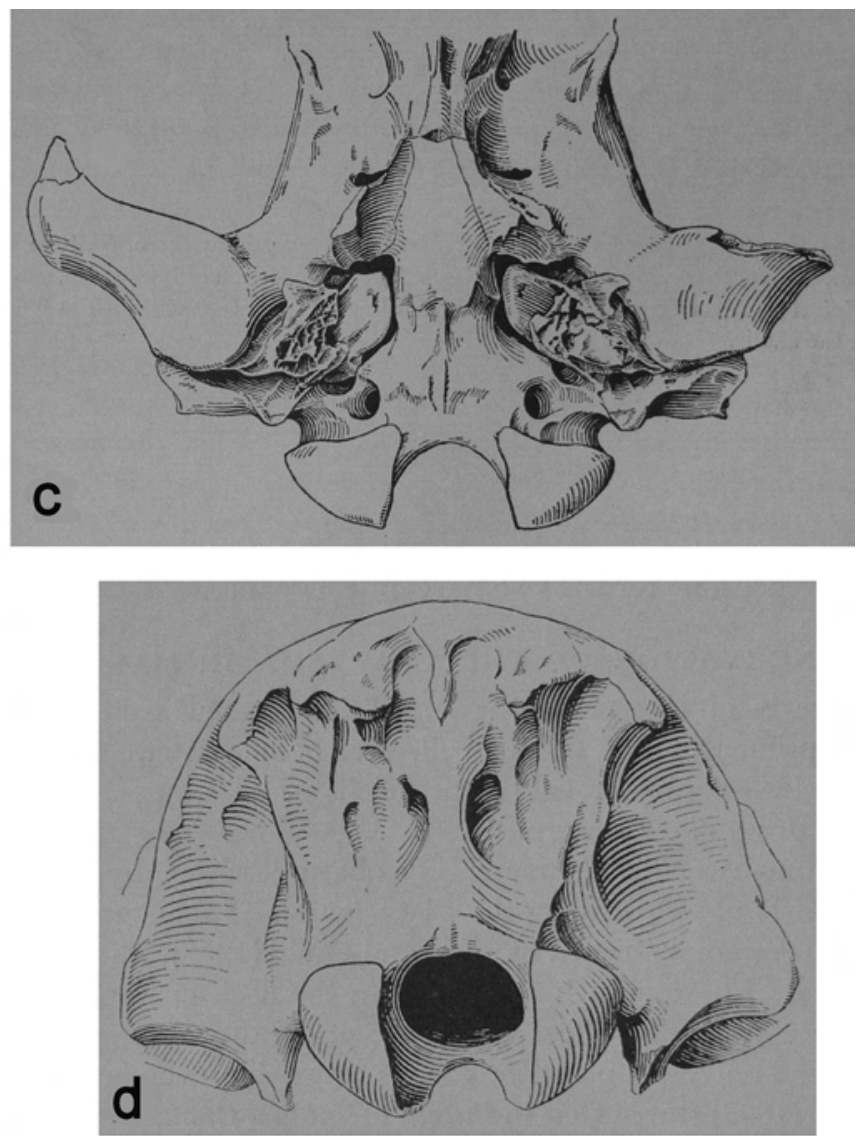

Figure 17. Morphology of the glenoid surface and occiput in (a, b) Merycopotamus Falconer \& Cautley, 1848, and (c, d) Hippopotamus Linnaeus, 1758 (modified from Pearson, 1929) (not to scale). 
hippo and palaeochoerid mandibles are fused soon after birth, whereas in most anthracotheres they usually remain unfused even in senile individuals. In Libycosaurus anisae the lower jaws of individuals with deeply worn third molars show no signs of symphyseal fusion in contrast to young hippo mandibles still containing the deciduous dentition, where the two halves of the jaw are difficult to separate from each other (Weston, 2003) just as they are in suids and palaeochoerids. There seems to be a problem with comprehension of the word «fused», arising in part from the literature. What Laws (1968) reported was that hippo mandibles remain unfused (or «open») until about 10-13 years of age. This has sometimes erroneously been taken to mean that the two halves of the jaw are separated from each other until this age, which appears to be the interpretation that Boisserie et al. have adopted. However, what Laws (1968) wrote was that fusion is not completed until 10-13 years of age, his criterion being that the two halves of the jaw can be moved with respect to each other until that age (scored by him as «open») after which they generally cannot (scored by him as «closed»). As it happens, hippo mandibles show progressive fusion of the symphysis, as in all mammals in which there is fusion between two bones or parts of bones. What differentiates hippos from Libycosaurus is that in the former the separation of the two halves of the mandible becomes difficult or impossible 3-4 years after birth or even earlier, whereas in the latter, the mandibles remain easily separable, even in senile individuals. Lihoreau (2003) report that the symphysis of Libycosaurus petrocchii from Chad is unfused, whereas that of Libycosaurus sp. nov. of Lihoreau (2003) is fused. This is interesting, because in the larger sample from Beglia, Tunisia, none of the Libycosaurus petrocchii mandibles is fused (Libycosaurus anisae in Pickford, 2006, submitted) in which case symphyseal fusion in the genus Libycosaurus developed after about 10 Ma. Except for one aged individual in the Natural History Museum, London, and another at Harvard University in America (Lihoreau, 2003) the mandibular symphysis of Merycopotamus, like that of Libycosaurus, is generally not fused, even in adult individuals. It is difficult to escape the conclusion that life history (in this case, growth) variables in hippos and anthracotheres, such as fusion of the symphysis, differed radically.

In hippopotamids, the descending plate of the mandibular angle flares outwards at a marked angle. This morphology allows the jaw to be opened extremely widely, the angle of the jaw not interfering with the neck when the jaw is wide open, as for example in the open-jawed ritual display that typifies hippopotamid social interactions. The descending plate in the mandible of Merycopotamus in contrast, does not diverge to any great extent, if anything they converge slightly ventrally, as in pigs and other anthracotheres. Under these circumstances, Merycopotamus would not have been able to open its jaws nearly as widely as hippos do, from which I conclude that the ritual display system in this genus (if it had any) would have been quite different from that of hippos.

\section{Dental evidence}

Boisserie et al. (2005a, 2005b) illustrated differences between molar morphology of the New World peccary, Tayassu, on the one hand and those of hippos and Libycosaurus, among other Suiformes, on the other. The demonstration that Tayassu has molars that are morphologically divergent from those of hippos does not refute the palaeochoerid hypothesis (Pickford, 1989) although it does weaken the tayassuid one.

The lower incisors of Libycosaurus were depicted by Boisserie et al. (2005a) as having prolonged to permanent growth, a description that was used to support the inference of a close relationship between this genus and hippos. Hippo lower incisors are hypselorhyzic, the crown rapidly disappearing with wear, leaving an elongated cylindrical root that continues to erupt throughout life (the pulp canal at the root apex remains open throughout life). Lower incisors of Libycosaurus petrocchii in contrast are of the usual mammalian kind, with a crown that erupts to gingival level, after which the tooth stops erupting (Fig. 18). As in many other mam-

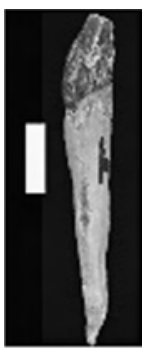

a1

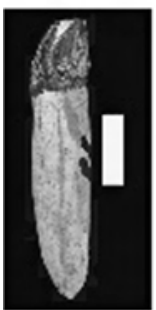

b1

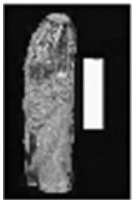

c1

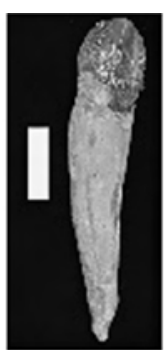

a2

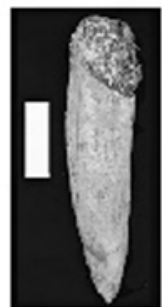

b2

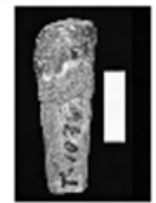

c2

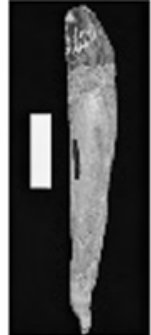

a3

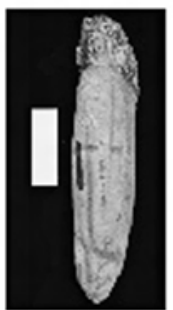

b3

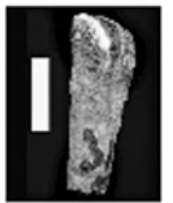

c3

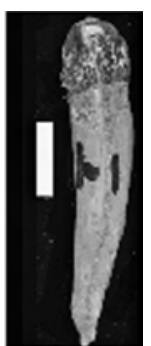

a4

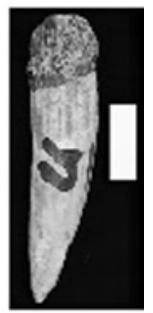

b4

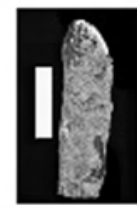

c4
Figure 18. Lower incisors of Libycosaurus petrocchii Bonarelli, 1947 [L. anisae (Black, 1972) in Pickford, 2006] (scale: $10 \mathrm{~mm}$ ). 
mals root growth continues until maturity when the apex of the root closes off (Pickford, 2006, in press).

The upper canines of Libycosaurus petrocchii were described by Boisserie et al. (2005a, character 55) as being vertically oriented. My examination of the species (Libycosaurus anisae in Pickford, 2006) reveals that the canine root is almost horizontal in the maxilla, its apex lying slightly above palatal level and lateral to the roots of the premolars, the apex lying beside the roots of P3/, and the crown is procumbent, although it does develop a vertical wear facet by abrasion against the lower canine. The orientation of the canine in Libycosaurus is thus radically different from that of hippos in which the internal apex of the canine (which incidentally has no root: ie is hypselodont) teminates well above palatal level.

The canines of Libycosaurus were described as evergrowing by Boisserie et al. (2005b) as in hippos. However, the canines of Libycosaurus petrocchii from Beglia, Tunisia (hitherto known as Libycosaurus anisae) are not permanently growing, neither is their growth prolonged (Fig. 19, 20). Pickford (2006, in press) showed that upper and lower canines in Libycosaurus petrocchii are normal mammalian canines in which the crown is clearly differentiated from the root by a cervix, and that the root of the canine is closed once maturity is reached. The crowns of these teeth erupt to gingival level, and then stop erupting, a major difference from hippo canines, which are hypselodont (arhyzic) and in which growth and eruption continue throughout life.

Character 58 in Boisserie et al. (2005a) concerns the lower canine section. Libycosaurus petrocchii is scored as having a triangular or 'D-shaped' section, which is surprising because material of this species from Tunisia has an ovoid section with a sharp distal crest (Pickford, 2006). The same acute distal crest is observed in the genus Merycopotamus.

Boisserie et al. (2005b) described the transverse sectional shape of the canines of most Bothriodontinae as being not very different from that of hippopotamids. However, the lower canines of Libycosaurus petrocchii are markedly divergent from the 'kidney-shaped' (or 'D-shaped) section that typifies hippo lower canines (Fig. 13). Pickford (2006) described the canines of Libycosaurus petrocchii (at the time identified as L. anisae) in detail and showed that the crown is canted on the root at an angle of about $30^{\circ}$ such that in anterior view the two crowns form a dihedral angle of $60^{\circ}$ with respect to the roots which are almost parallel to each other, very different from the almost vertically oriented lower canines of hippos as seen from the front in which there is no sign of canting of the tooth. Furthermore, in hippos, the lower canine is composed of two parts (buc-
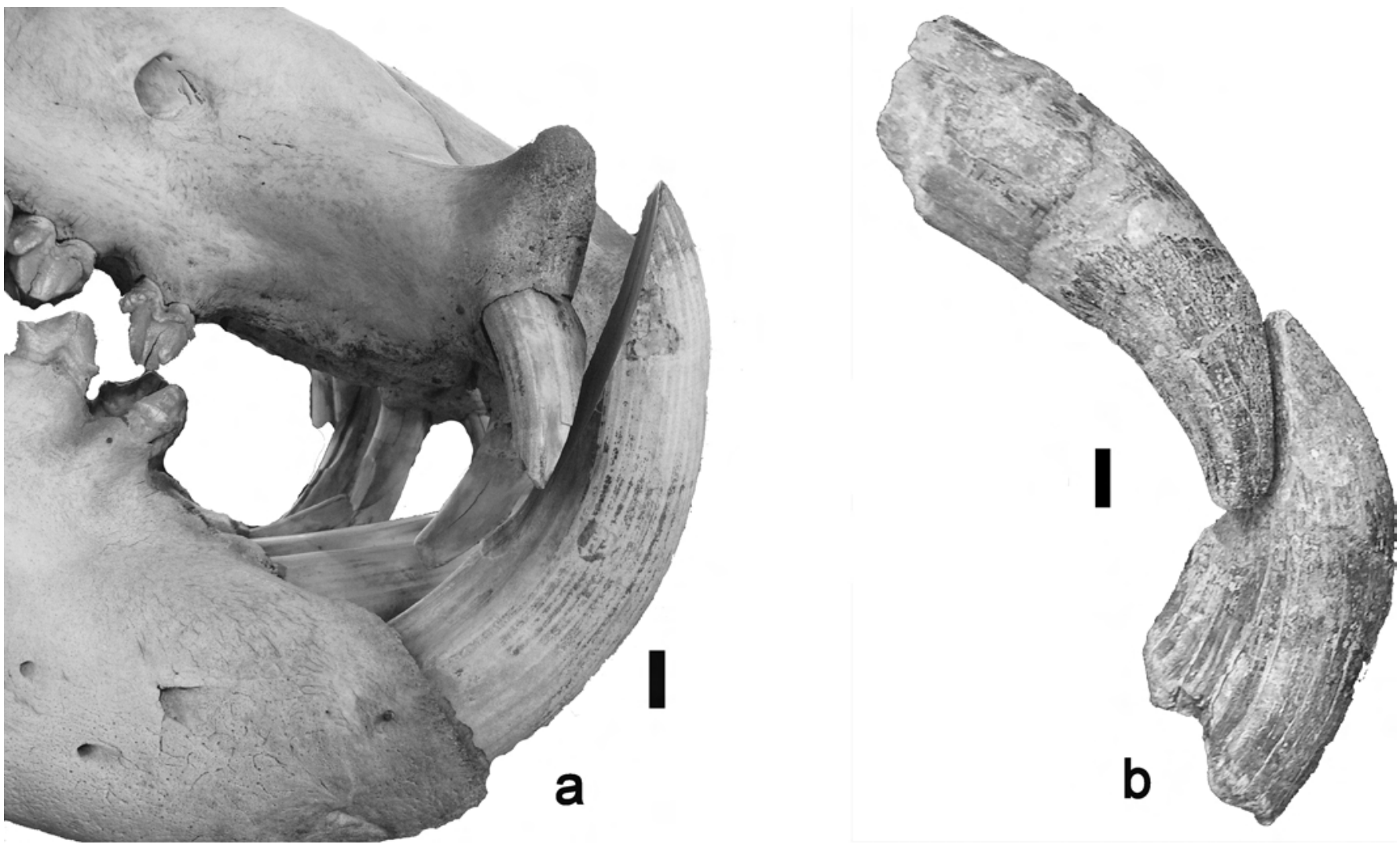

Figure 19. Male canines of (a) Hippopotamus amphibius Linnaeus, 1758 and (b) Libycosaurus petrocchii Bonarelli, 1947, lateral view; (b) is from Pickford, 2006) (scale for Libycosaurus: $10 \mathrm{~mm}$ ). 

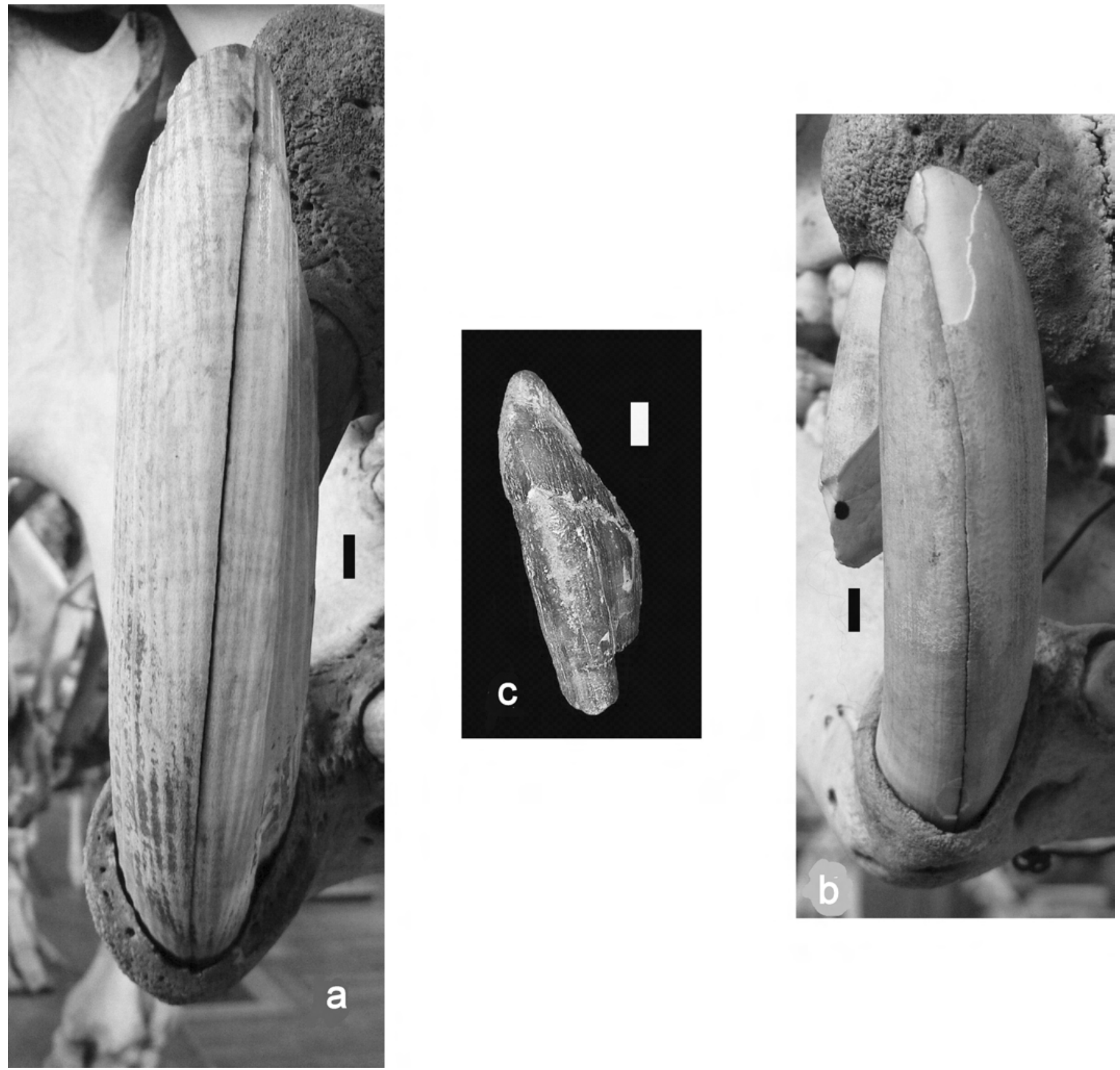

Figure 20. Anterior views of right canines of (a) Hippopotamus amphibius Linnaeus, 1758, (b) Libycosaurus petrocchii Bonarelli, 1947, and (c) Choeropsis liberiensis (Morton, 1849). Note the orientation of the teeth (almost vertical in hippos and dihedral in Libycosaurus) and the tendency for hippo lower canines to split longitudinally (scales: $10 \mathrm{~mm}$ ).

cal and lingual) that are poorly bound to one another, so that the teeth easily split longitudinally, especially when they become desiccated (Fig. 20). Anthracothere canines are seldom if ever found split in half like those of hippos (Fig. 20). Examination of the dentine of lower canines of Merycopotamus and Libycosaurus reveal that it is massive and homogeneous, whereas it is hemicentrically layered in hippopotamids. In the latter group the lower canine is comprised of lingual and buccal halves which are weakly joined along a slightly curved longitudinal junction, the dentine in each part being independently hemicentrically layered. This explains the difference in splitting tendency of these teeth. Surface morphology and internal structure of lower canines comparable to those of hippopotamids is unknown in any anthracotheres, including Libycosaurus and Merycopotamus. This finding weakens the scenario of a close relationship that Boisserie et al. (2005a) postulated between hippos and the latter genera.

A lower canine of Kenyapotamus Pickford, 1983, from Beglia, Tunisia, shows typical hippopotamid morphology 
(Pickford, 2006), meaning that this type of canine existed in kenyapotamines about 12-10 Ma contemporary with Libycosaurus petrocchii.

Boisserie et al. (2005a) concluded that hippo canines, like those of anthracotheres, are sexually dimorphic, contrary to what Pickford (1989) wrote. There appears to be some confusion here between the concepts of dimorphism and bimodality. Although many authors use the word dimorphism for size and/or morphological differences between elements of the two sexes, it is better to differentiate between size differences (bimodality) and morphological differences (dimorphism) and not to amalgamate the two concepts into one word. In fact what Pickford (1989) wrote was that hippo canines were weakly dimorphic, and this is indeed the case, the shapes of male and female canines being similar. Hippo canines are also weakly bimodal, there being a great deal of overlap between the dimensions in males and females. In anthracotheres in general, and in Libycosaurus in particular, the canines are highly sexually dimorphic (Fig. 21) and extremely bimodal (Pickford, 1991, 2006). There is thus a major difference between the degree of canine dimorphism and bimodality in this genus of anthracotheres and hippopotamids.

Every specimen of Libycosaurus preserving the anterior part of the adult upper cheek dentition or the alveolar margin, reveals that this genus was characterised by the presence of an accessory premolar (Pacc in Pickford, 2006).
This was first noted in the Beglia species Libycosaurus petrocchii (= L. anisae) (Fig. 22) and in Libyan Libycosaurus petrocchii by Pickford (1991) and was subsequently reported to occur in Chadian Libycosaurus petrocchii and Libycosaurus sp. nov. (Lihoreau, 2003). The presence of five premolars in Libycosaurus is unique among Artiodactyla, the primitive number of premolars being four, with many lineages, including hippopotami, possessing a tendency to reduce the number of premolars starting at the front of the row.

Boisserie et al. (2005a) referred to one of the characters (comparison of the relative importance of cingular height in palaeochoerids and hippopotamids) used by Pickford (1989) to link palaeochoerids to hippos as being «meaningless». The employment of this adjective suggests that the authors have failed to understand the significance of what Pickford was describing. The molars of some palaeochoerids, like those of early hippopotamids such as Palaeopotamus ternani (Pickford, 1983) (Pickford, 2007) have a crown which sits atop a solidly fused root base, the apices of the roots only separating from this substantial base some distance beneath cervix. In such forms the cingulum is deeper than it usually is in those artiodactyls which have completely unfused roots, including anthracotheres, particularly Libycosaurus. This morphology is relatively rare among mammals, but is common in palaeochoerids (Palaeochoerus, Choeromorus, Lorancahyus Pickford \& Morales, 1998) and typifies kenyapotamines
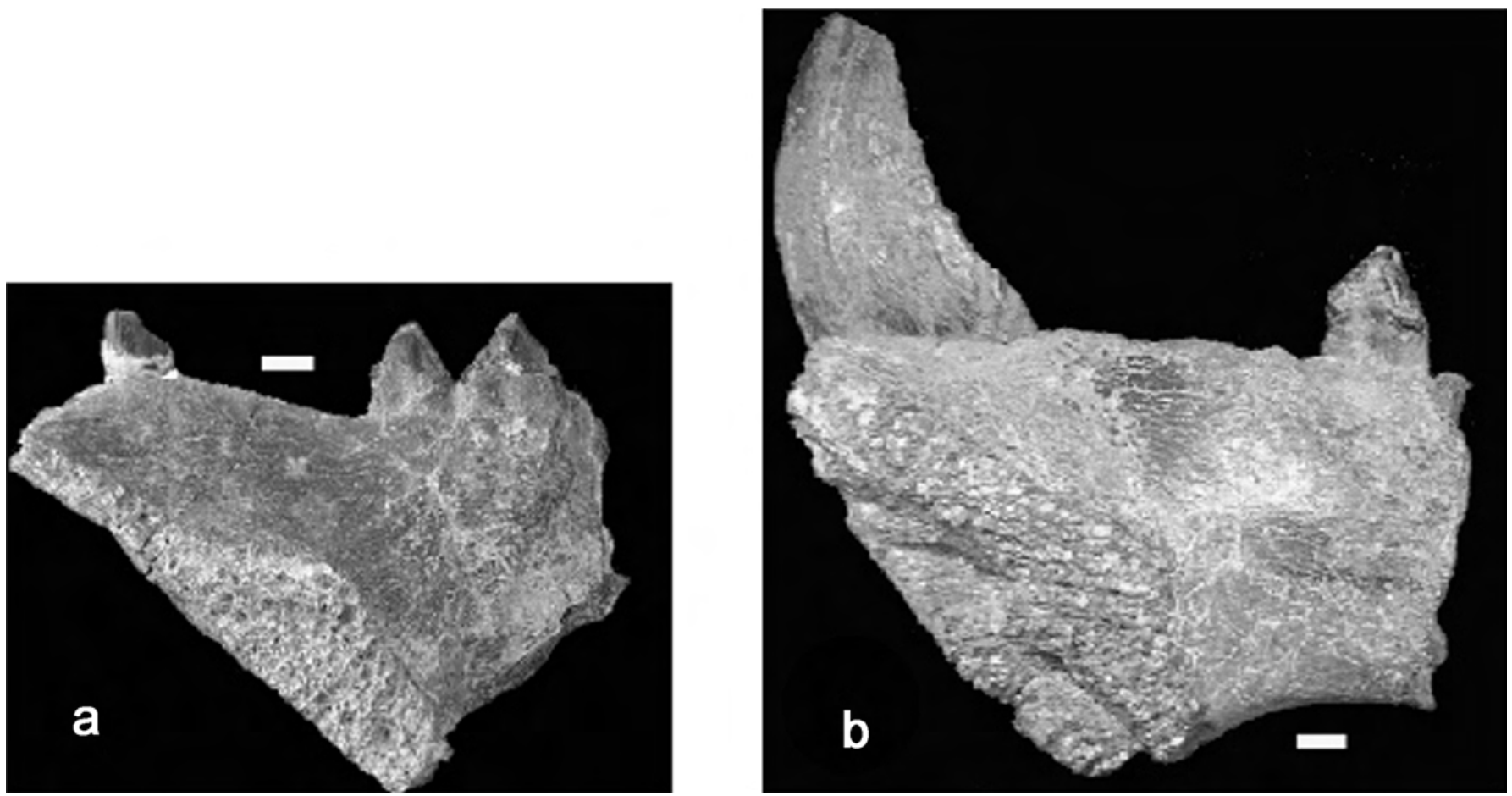

Figure 21. Canine dimorphism in Libycosaurus petrocchii Bonarelli, 1947, (a) female, (b) male, lingual views (from Pickford, 2006) (scale: $10 \mathrm{~mm}$ ). 


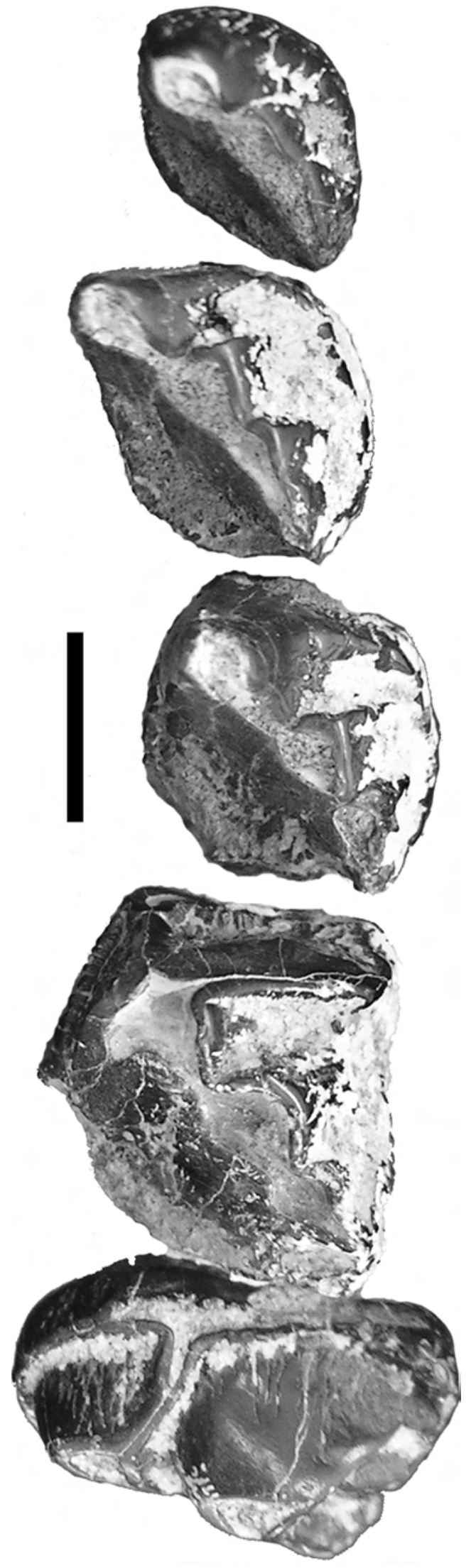

Figure 22. Accessory upper premolar in Libycosaurus petrocchii Bonarelli, 1947. The bicuspid P4/ is preceded by four unicuspid premolars that diminish in size anteriorly (scale: $10 \mathrm{~mm}$ ).
(Palaeopotamus Pickford, 2007, Kenyapotamus Pickford, 1983 ) and in a somewhat subdued form also occurs in hippopotamines. In my opinion such a character provides important evidence of relationships between some palaeochoerids and hippopotamids, and should not be dismissed out of hand as being meaningless.

The upper third molars of Suidae often have a talon (pentacone) behind the four main cusps, and Boisserie et al. (2005b) rightly pointed this out as a significant difference from hippopotamids. However, in their character matrix they scored it as present in the palaeocheorid $\mathrm{Pal}$ aeochoerus, yet it is absent (Hellmund, 1992) a difference that affects their cladistic analysis. The pentacone is also absent in Propalaeochoerus Stehlin, 1899, and Choeromorus (which used to be called Taucanamo) and there is a small cingular cusplet but not a true pentacone in Schizochoerus Crusafont-Pairo \& Lavocat, 1954, all of which are Palaeochoeridae. Neither Kenyapotamines nor Hippopotamines have a pentacone in the M3/, a fact that reinforces the possibility of a relationship between the hippos sensu lato and the palaeochoerids. Re-examination of the fossils attributed to Xenohyus Ginsburg, 1980 (Ginsburg et al., 1988; Pickford \& Morales, 1989; Bouvrain \& de Bonis, 1999) indicates that they are suids, which modifies the evidential basis of the palaeochoerid hypothesis of hippopotamid origins, but does not result in refutation of the hypothesis itself.

Boisserie et al. (2005a, 2005b) considered that pustulate and/or wrinkled tooth enamel was an important character, scored as present in Kenyapotamus, Choeropsis, Hippopotamus, Hexaprotodon, Libycosaurus, and Brachyodus among other taxa analysed, but absent from tayassuids, Doliochoerus and Xenohyus. However, the finely wrinkled enamel that typifies the cheek teeth of the anthracotheres Libycosaurus and Brachyodus is not homologous to the more coarsely wrinkled enamel that occurs in Palaeopotamus, Kenyapotamus and other hippos. Furthermore, the denticles on the premolars of Libycosaurus are not the same as the pustules on the premolars of hippopotamids. Not only do they occur in different parts of the dentition, but also their structure is divergent, denticles being compressed and sharp edged when unworn and pustules being blunt and rounded when unworn. Thus character 60 in Boisserie et al. (2005a) which is the same as character 31 of Boisserie et al. (2005b) represents an amalgam of two categories of morphology a) type of wrinkling (coarse versus fine) and $b$ ) enamel ornamentation (pustules versus denticles) which are not homologous in the taxa examined (Pickford, in press). Therefore inferences drawn about proximity of relationships based on the presence of the amalgamation of these characters in the taxa are invalid. The denticulation of the premolars of Libycosaurus led Bonarelli (1947) to classify this anthracothere as a dinosaur, hence its name. It appears that these denticles continue to cause confusion. 
As was already noted by Falconer (1868) finely wrinkled enamel similar to that in the molars of Merycopotamus occurs in other ruminants, such as the giraffe and the sivathere. Indeed, it was this feature, together with the selenodont morphology and wear pattern of the teeth, and the great difference in the breadths of upper and lower cheek teeth, that prompted Falconer (in Owen, 1845) to name the genus Merycopotamus «merico» meaning ruminant in Greek. In herbivorous mammals wrinkling of enamel in cheek teeth is often associated with a cover of cementum, the wrinkles providing a rugose surface onto which the cementum is bound. Without such a roughened substrate the cementum would tend to spall off during chewing. Fine wrinkling of the enamel such as occurs in Brachyodus and Libycosaurus occurs in many mammalian groups, such as elephantids, suids, hippos and ruminants including cervids, giraffids and some bovids. Taken on its own, this character has almost no phylogenetic signal. Given the widespread occurrence of finely wrinkled enamel in artiodactyls its use by Boisserie et al. (2005a, 2005b) to draw inferences about close relationships between anthracotheres and hippos is suspect.

Pickford (1991) already responded to other proposals that linked the evolution of hippo dentitions from those of anthracotheres.

\section{Dental plasticity}

Boisserie et al. (2005b) wrote that hippo cheek tooth derivative from selenodont teeth of the Bothriodontinae would necessitate a spectacular reversion. In a search for support for this hypothesis which they recognised as being "poorly parsimonious" they appealed to Naylor \& Adams (2001) who wrote that «mammalian teeth could be more plastic than classically suspected, therefore often found to be homoplasic and therefore notably responsible for the discrepancies between molecular and morphological data bearing on cetacean relationships».

I agree that if hippo teeth evolved from an anthracothere dental 'grundplan' (in particular a bothriodontine one) then this would indeed represent a spectacular case of dental plasticity. But before accepting such a scenario, I would like to see evidence for it. Derivation of hippopotamid dental morphology from a palaeochoerid ancestor would require relatively modest adjustments to the dental 'grundplan', with Palaeopotamus and Kenyapotamus providing evidence of how this was achieved (Pickford, 2007). For this reason I am unable to agree with Boisserie et al. (2005b) when they write that «the absence of any known anthracotheriid lineage that also gradually and simultaneously developed hippo-like cranial and dental morphologies is not a decisive argument to reject the strongly supported relationship between
Hippopotamidae and Anthracotheriidae». The concept of dental plasticity strongly opposes the observation by Kowalevsky $(1873$, p. 24) that «Every mammalogist is aware of how constant are the dental characters in large groups of Mammalia».

Finally, in contrast to the hypothesis of dental plasticity, Boisserie (2005) wrote that «hippo cheek teeth show only minor variations, and these variations can be found in most of the known species» thereby confirming constancy of dental morphology among hippopotamines in agreement with Coryndon's (1976, 1977, 1978a, 1978b) and other researchers' writings (Harris, 1991; Pickford, 1993; Harrison, 1997). As such, the concept of dental plasticity as employed in support of derivation of hippopotamids from anthracotheres is unsustainable.

\section{Intermolar size relationships}

Falconer \& Cautley (1836) noted that in Merycopotamus the relationship between the breadths of the lower molar row compared to the upper molar row was comparable to that observed in ruminants (ie lower molars are very narrow compared with uppers) and differed from that in hippos and suids in which the lower molars are not as exaggeratedly narrow. Matthew (1929a) noted that the "bunodont" Artiodactyla possessed molars which had similar lengths and breadths whereas anthracotheres did not. Examination of the dentitions of bunodonts and anthracotheres reveals that the first molar in anthracotheres is appreciably smaller than the second and third molars, whereas in hippos (Fig. 23) suids, palaeochoerids and peccaries the first molar is only slightly smaller than the second and third ones. If anthracotheres are to be the ancestors of hippos, then they would not only have to have undergone "spectacular" modification of their dentitions (Boisserie et al., 2005a) but they would also have had to have modified the intermolar size relationships convergently with other bunodonts at the same time as broadening the lower cheek teeth relative to the upper ones. It is perhaps more parsimonious to conclude, as did Falconer \& Cautley (1836) and Matthew (1929b) that hippo dentitions resemble those of bunodonts, not only in morphology, but also in intermolar relations, because they are part of the same group.

\section{Postcranial evidence}

\section{The neck}

Lydekker (1876) first recorded the presence of a long neck in Merycopotamus based on the elongation of the axis vertebra, which he described as being akin to that of a ruminant. Geais (1934) reported that the neck of Elomeryx borbonicus was similar to that of the wild boar in 

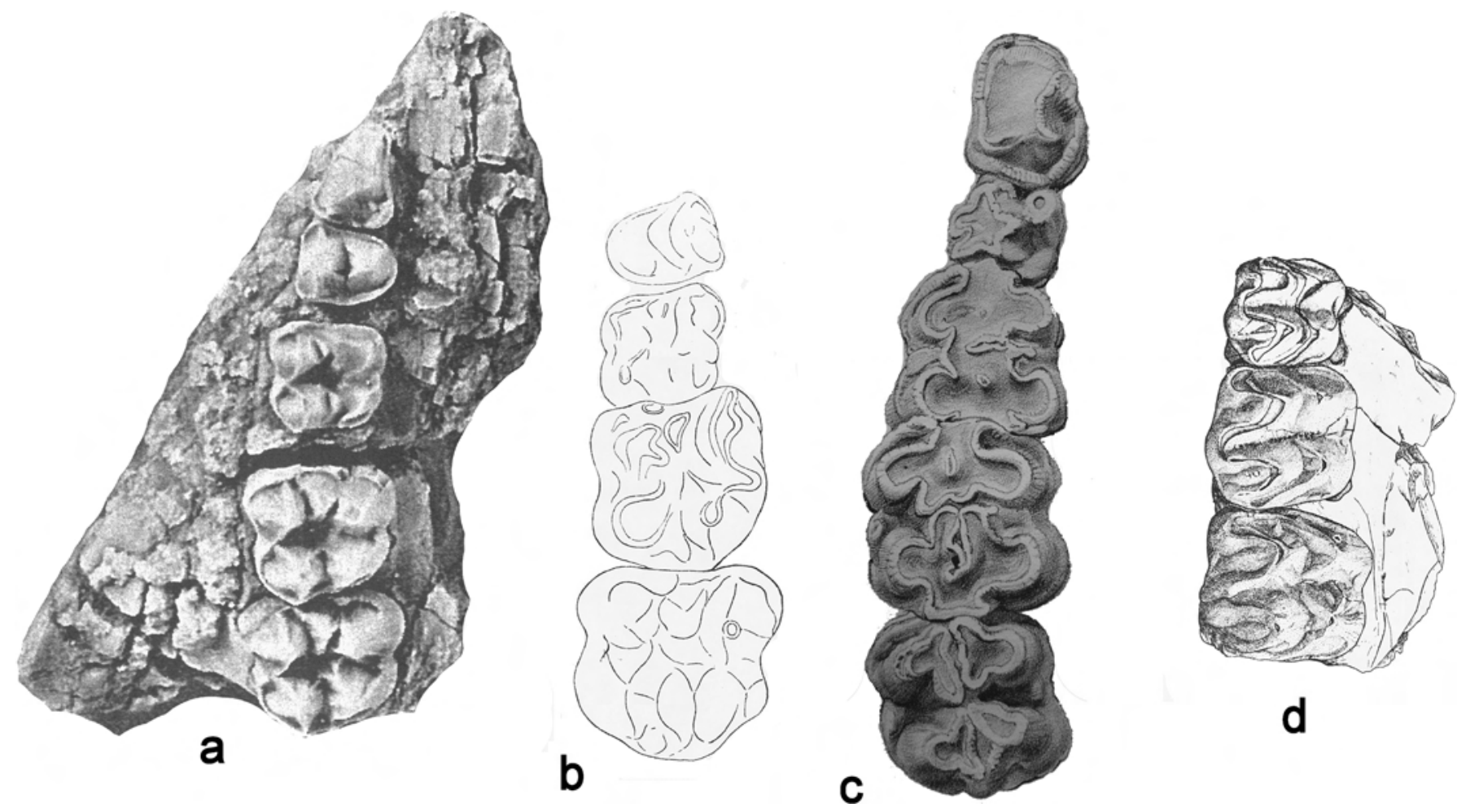

Figure 23. Intermolar size relationships of anthracotheres and hippopotamids, (a) Anthracotherium Cuvier, 1822, from Pondaung, Burma, (b) Anthracotherium magnum Cuvier, 1822, from France, (c) Hippopotamus amphibius Linnaeus, 1758, (d) Libycosaurus petrocchii Bonarelli, 1947, from Beglia, Tunisia (modified from Tsubamoto et al., 2002; de Blainville, 1846; and Black, 1972, respectively) (not to scale).

aspect and dimensions which suggests that the neck was relatively more elongated than it is in hippopotamids. The atlas vertebra of Libycosaurus anisae from Beglia, Tunisia (now classified as L. petrocchii) was first described as a giraffid vertebra (Crusafont-Pairo, 1979) which underlines the observation made by Lydekker (1876) about neck length in bothriodonts, although further evidence about anthracothere neck length would be welcome. A recently discovered cranium of Brachyodus aequatorialis associated with parts of the post-cranial skeleton including the vertebral column, reveal that this bothriodont possessed a long neck.

\section{Limbs}

The failure to include any suiform long bones in the analysis by Boisserie et al. $(2005 \mathrm{a}, 2005 \mathrm{~b})$ is a major weakness of their research programme, mainly because it is essential to include the postcranial skeleton when deducing relationships between artiodactyl groups (Kowalevsky, 1873, 1874; Lydekker, 1876; Matthew, 1929a). Lihoreau (2003) who wrote that, with the exception of the talus and metapodials, he could not distinguish the postcranial bones of the bothriodont anthracothere, Libycosau- rus, from those of hippos. In contrast, Pickford (2006) described many differences between the limb bones of hippos and Libycosaurus petrocchii from Beglia, Tunisia, a finding that is supported by further research on other bothriodonts (see below).

\section{Humerus}

Lydekker (1876) showed that the morphology of the proximal humerus in Merycopotamus was different from that of hippos, notably in the relation of the bicipital groove to the tuberosities and the head, which affects the openness of the groove (Fig. 24).

The morphology of the distal humerus of Libycosaurus, like that of Merycopotamus (Falconer \& Cautley, 1848) is markedly divergent from those of Choeropsis and Hippopotamus. In Hippopotamus amphibius there is a deeply excavated anterior fossa between the epiphysis and the diaphysis. Because of the great depth and expanded surface area of this fossa, hippos can hyperflex their forearm onto the humerus, probably part of the hippopotamid adaptation for running rapidly from land into water and for underwater locomotion (when hyperflexed, the foreleg retracts largely within the thoracic mass leaving only the 

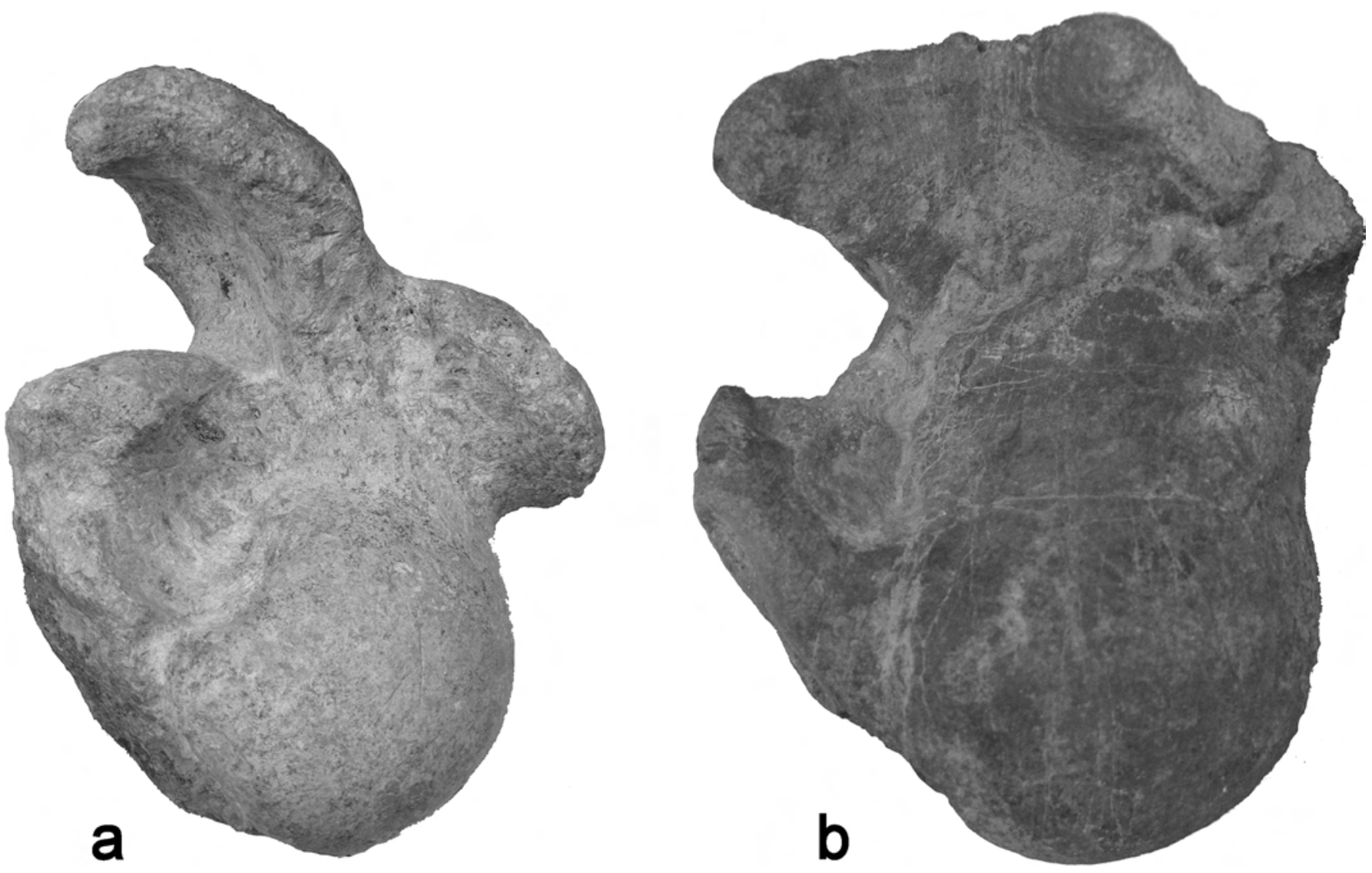

Figure 24. Morphology of proximal humeri of Hippopotamus Linnaeus, 1758, sp. (a) from Sicily) and Merycopotamus dissimilis (Falconer \& Cautley, 1836) (b) from the Upper Siwaliks, India) (not to scale).

distal radio-ulna and feet exposed, thereby streamlining the outline of the body and reducing drag). The distal humeral fossa in Choeropsis is shallower than in Hippopotamus, and thus forearm flexion was less extreme than in the more amphibious hippos. In Hippopotamus madagascariensis Guldberg, 1883, the anterior fossa is also large and in many adult individuals the lateral pillar of the humerus sports a wide groove where the lateral anterior lip of the radius slots into the fossa (Fig. 25). This groove is due to remodelling of the bone rather than to abrasion. This morphology shows an extreme flexion of the forearm towards the humerus in both the Madagascan and African hippos. The fossa in Libycosaurus and Merycopotamus is much less marked, is shallower, and has a smaller surface area. Forearm flexion in these genera was of the ordinary terrestrial mammalian kind, suggesting that in these forms foreleg drag was a likely hindrance to efficient underwater locomotion.

The medial epicondyle in hippo humeri is a low swelling medial to the trochlear margin. In Libycosaurus and Merycopotamus in contrast, the medial epicondyle is extensive and salient, flaring well away from the trochlear margin. There are more subtle differences between the humeri of anthracotheres and hippos, such as the position of the weight-bearing anterior ridge of the diaphysis, which passes slightly medial of the trochlea in hippos, and in line with the medial edge of the trochlea in Libycosaurus. Functionally, the humeri of hippos and Libycosaurus are quite different in detail, the morphological features of the elbow joint indicating divergent locomotor repertoires, a greater degree of flexion of the forearm towards the humerus in hippos, and much less in Libycosaurus and Merycopotamus. Examination of three distal humeri of Brachyodus onoideus (Gervais, 1859) revealed overall similarities to those of Libycosaurus and differences from Hippopotamus.

In posterior view the two distal pillars of the humerus of Libycosaurus form an almost symmetrical Y-shape with respect to the long axis of the diaphysis (Pickford, 2006) (Fig. 26). In hippos, the lateral pillar is in line with the diaphysis, while the medial one diverges strongly (Fig. 26). In lateral view the distal articulation of Libycosaurus is less offset anteriorly than it is in hippos. The deltoid crest is well developed in hippos and descends close to the distal end, but is weakly expressed in Libycosaurus in which it terminates more proximally on the humerus. In the general morphology of the distal humerus hippos are closer to Suoidea than they are to Anthracotherioidea. 

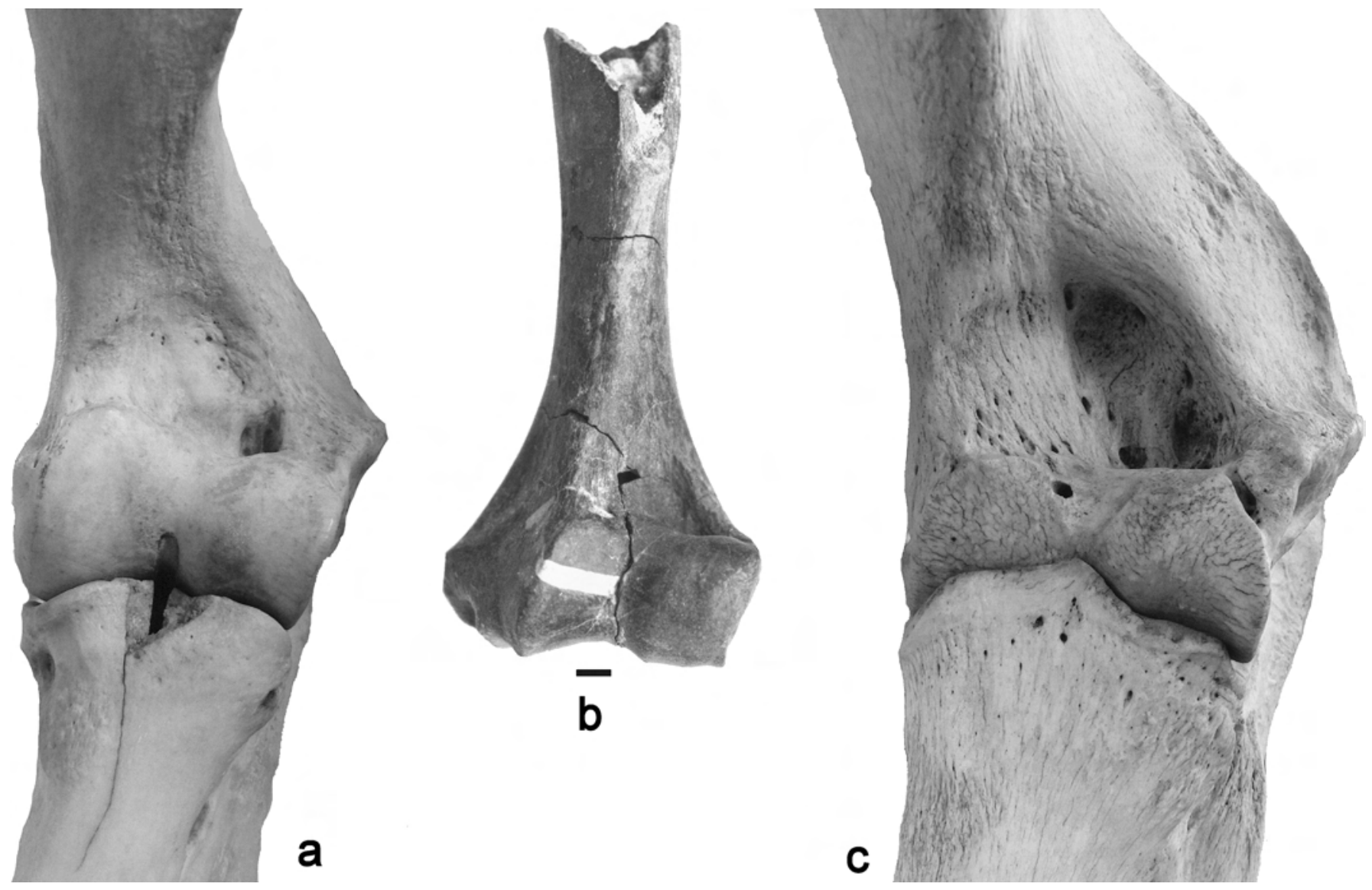

Figure 25. Morphology of distal humeri, anterior views (a) of Choeropsis liberiensis (Morton, 1849), (b) Libycosaurus petrocchii Bonarelli, 1947, from Pickford (2006) and (c) Hippopotamus amphibius Linnaeus, 1758. Note the enlarged, deepened fossa above the distal articulation of hippo humeri, and the shallow fossa in Libycosaurus, the usual artiodactyl condition (scale for Libycosaurus: $10 \mathrm{~mm}$ ).

\section{Radio-Ulna}

The radio-ulna of Merycopotamus, unlike that of hippopotamids, is not ankylosed (Lydekker, 1876). The olecranon process in anthracotheres such as Ancodon is quite straight, almost like those of ruminants (Andrews, 1906) whereas in Hippopotamus and Choeropsis its apex is markedly recurved medially and overhangs an expansive medial fossa (Fig. 27). The olecranon process of Merycopotamus has not been described but the main part of the ulna and the radius are more elongated than the corresponding bones in Hippopotamus (see Lydekker, 1883).

\section{Proximal femur}

In the proximal femur, the anthracothere Libycosaurus petrocchii possesses a prominent and robust tubercle of bone on the anterior aspect of the diaphysis close to the greater trochanter, called the femoral tubercle by Pickford (2006). Somewhat similar overall morphology occurs in
Brachyodus onoideus. Hippos possess a low ridge of bone in roughly the same place, but its form and shape are different. This tubercle is the insertion point of connective tissue that extends between the proximal femur and the pelvis, and serves to prevent the hip joint from becoming disarticulated. In both Hippopotamus and Choeropsis the femoral neck is long whereas in Libycosaurus it is remarkably short (Fig. 28) and this is probably why the tubercle anatomy in the two taxa is different. The greater trochanter in hippos is low and in anterior view does not extend proximally above the head of the femur, whereas in anthracotheres, it is elongated proximally, extending well above the femoral head (Fig. 29). There are thus significant anatomical differences between the proximal femur of this anthracothere on the one hand, and those of hippos on the other.

The hip joint in hippos is more flexible than that of Libycosaurus, which translates into a greater degree of movement of the joint in hippos than in the anthracothere. This is confirmed by the greater sphericity of the femoral head posed on a long femoral neck in hippos, and a slightly less spherical head on a shorter neck in the anthracothere. 


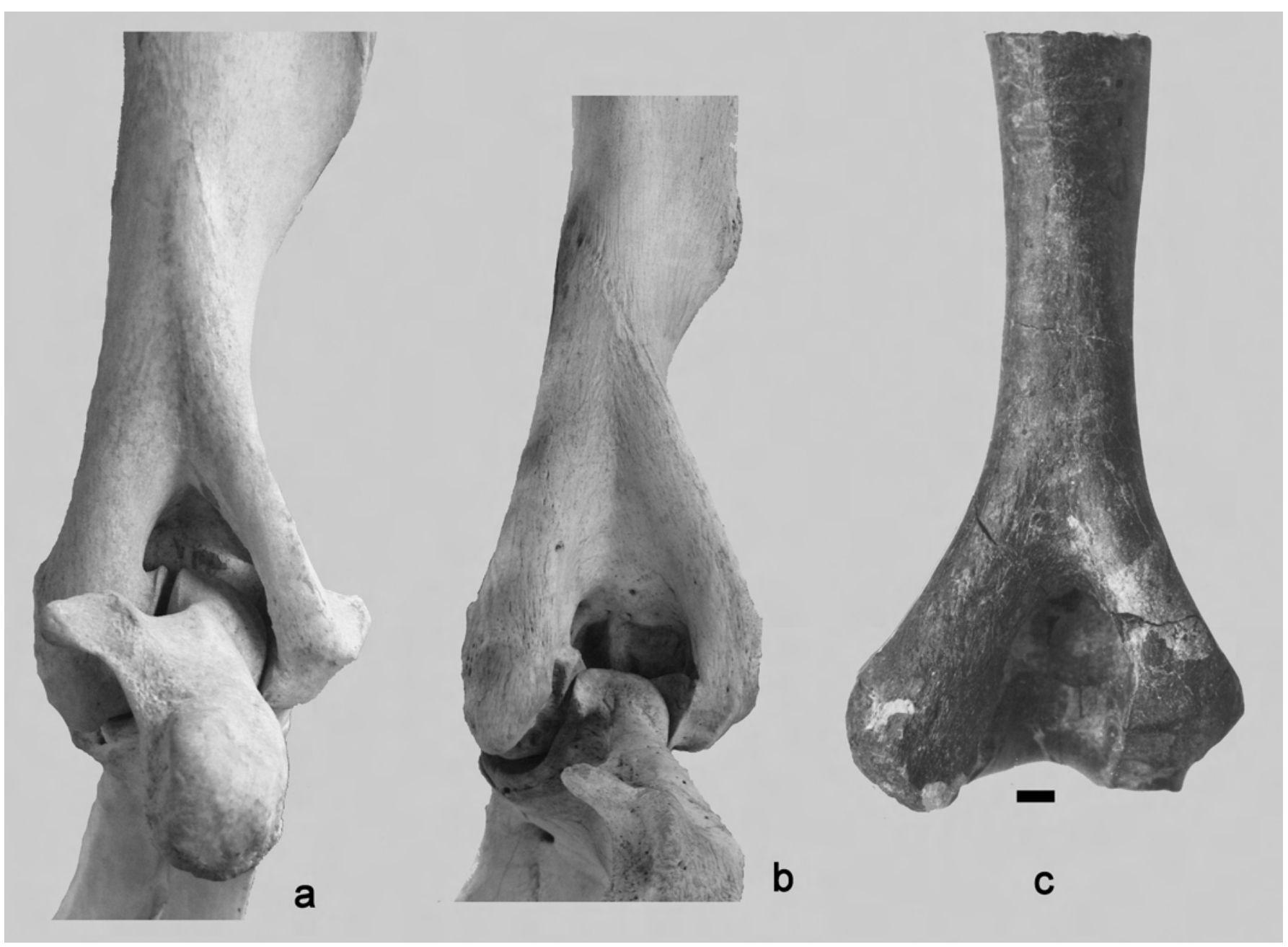

Figure 26. Morphology of distal humeri, posterior views (a) of Choeropsis liberiensis (Morton, 1849), (b) Hippopotamus amphibius Linnaeus, 1758, and (c) Libycosaurus petrocchii Bonarelli, 1947. Note the divergent almost symmetrical pillars in the anthracothere and the asymmetric pillars in hippos, the different development of the lateral pillar of the humerus and the weak deltoid ridge in Libycosaurus Bonarelli, 1947, compared to the large ridge in hippopotamids (scale for Libycosaurus: $10 \mathrm{~mm})$.

From the combined evidence of the elbow and hip joints, it is inferred that hippos had quite a different locomotor style from anthracotheres, with adaptations for running rapidly from land into water, rapid turning and underwater locomotion being better expressed in the hippos.

\section{Distal femur}

NHM M 2712 and NHM M 17979 are distal right femora from the Siwalik Hills, India (Falconer \& Cautley, 1848; Lydekker, 1885) (Fig. 30, 31). The most striking features of NHM M 2712 are the extensive and deep supracondyloid fossa, the subequal development of the trochlear lips, the greater development of the lateral supratrochlear ridge in contrast with that of the medial supratrochlear ridge, and the well defined supratrochlear depression.
The supracondyloid fossa is about $16 \mathrm{~mm}$ broad and 45 $\mathrm{mm}$ long and has an extremely rugose surface comprised of dense bony tubercles. Its margins are steep and overhang the fossa, unlike the shallow depression that occurs in hippos and the lack of depression in suids. In this feature the specimen more closely resembles equids than other artiodactyls. The two condyles are subequal in dimensions.

In most ungulates the lateral supratrochlear ridge is lower and more weakly developed than the medial one. However, in NHM M 2712, the lateral ridge is higher and thicker than the medial one, and it closes off the supratrochlear depression on its lateral side. As a result, the supratrochlear fossa is narrow and deep and does not slope markedly laterally. With the femoral condyles posed flat on a horizontal surface, it is seen that the trochlear gully is not as steeply inclined as it usually is in ungulates, in this respect being closer to the situation in suids than in other 


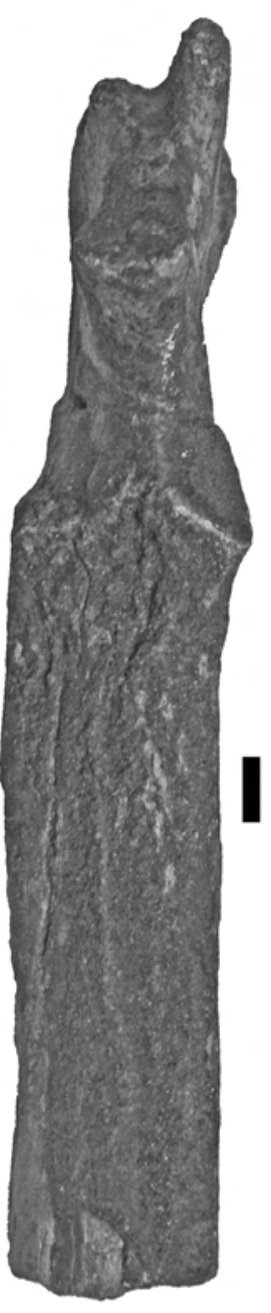

a

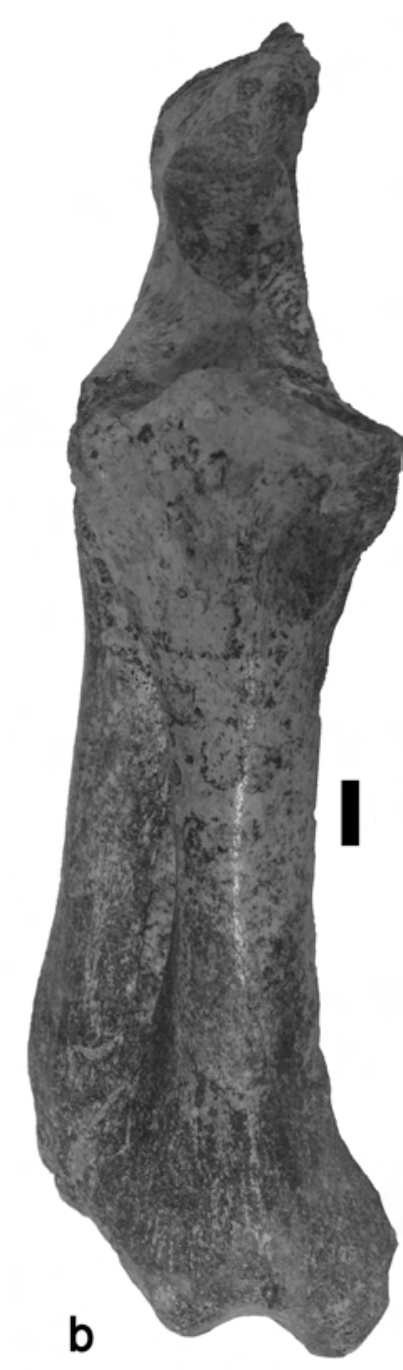

Figure 27. Morphology of the proximal ulna in anthracotheres (a) Ancodon gorringei Andrews, 1906, from the Fayum, Egypt, and hippopotamids (b) Hippopotamus sp. from Cyprus. The straight and medio-laterally flattened olecranon process of Ancodon contrasts strongly with the curved process of the hippo which is deeply excavated on its medial side (scale for Ancodon Pomel, 1847: $10 \mathrm{~mm}$ ).

suiforms. The medial trochlear lip is slightly inflated and is marginally bigger and taller than the lateral one. This conformation is quite different from the greatly expanded medial lip that occurs in hippos and most ruminants, and in this feature the Siwalik specimen is closer to suids than to other artiodactyls.

In NHM M 2712, the fossa for the femoro-metatarsal ligament is well developed, invaginating between the base of the trochlea and the lateral condyle. Damage in this area does not reveal whether there is a continuity between the trochlear and condyloid articular surfaces, although it seems likely that there was. The popliteal fossa is a well developed hemispherical depression.
NHM M 17979, a distal left femur (Falconer \& Cautley, 1848; Lydekker, 1885) is not as well preserved as NHM M 2712, but on the basis of its dimensions and morphology it evidently belongs to the same species (Fig. 30). The condyles and trochlea have been abraded, and there is still matrix in the supracondyloid fossa and the depression for the femoro-metatarsal ligament. The outline of the supracondyloid fossa indicates that it is deep and has overhanging walls. The supratrochlear fossa is extensive and even though the supratrochlear ridges are abraded it is evident that the lateral one was originally taller and broader than the medial one. Sediment filling the fossa for the femorometatarsal ligament prevents proper assessment of its morphology, but what is visible conforms with the situation in NHM M 2712. The popliteal fossa is shallow and weak. Lydekker (1876) described the condyles of this specimen as being sub-equal in size. This is indeed so, even though abrasion to the condyles has altered their appearance.

NHM G 12 is a distal left femur from Gebel Zelten, Libya, attributed to Sivameryx africanus (Andrews, 1914), a species which is common at the locality (Pickford, 1991). In general it is well preserved but it has suffered slight damage near the zone of the origin of the femorometatarsal ligament (Fig. 31). The supracondyloid fossa is deep with overhanging walls and its surface is adorned with dense bony tubercles. The fossa is $20 \mathrm{~mm}$ broad, but its length cannot be determined as its proximal part is broken off. In cranial aspect it is clear that the lateral supratrochlear ridge is taller and broader than the medial one, whereas the medial trochlear lip is more inflated and slightly taller than the lateral one. The fossa for the femoro-metatarsal ligament is deep and broad, but its medial edge is damaged so it is not possible to determine whether the trochlear and condylar articular surfaces were continuous or not. The popliteal fossa is weakly expressed. In distal view, it is possible to see that the intercondyloid fossa is separated into two moieties by a well developed ridge which separates the insertions for the cruciate ligaments. The crest delimiting the insertion of the medial head of the gastrocnemius is well defined. With the two condyles placed horizontally, the trochlear gulley is seen to be more weakly inclined than it is in hippos and most other artiodactyls other than suids. The two condyles are subequal in size.

Specimen OMD 93'28, housed in the Oranjemund $\mathrm{Mu}-$ seum, Namibia (Pickford, 2003) is an almost complete femur of Brachyodus aequatorialis MacInnes, 1951, lacking only the head and neck, collected at Auchas, Orange River valley from deposits aged about 19 Ma (Fig. 30). It is reconstructed from three pieces, and there is some plaster-of-paris infilling missing pieces of cortex, including parts of the supracondyloid fossa. It has a large and deep supracondyloid fossa, judging from the proximal and distal portions which are well preserved. The medial supratrochlear ridge is slightly higher and better devel- 

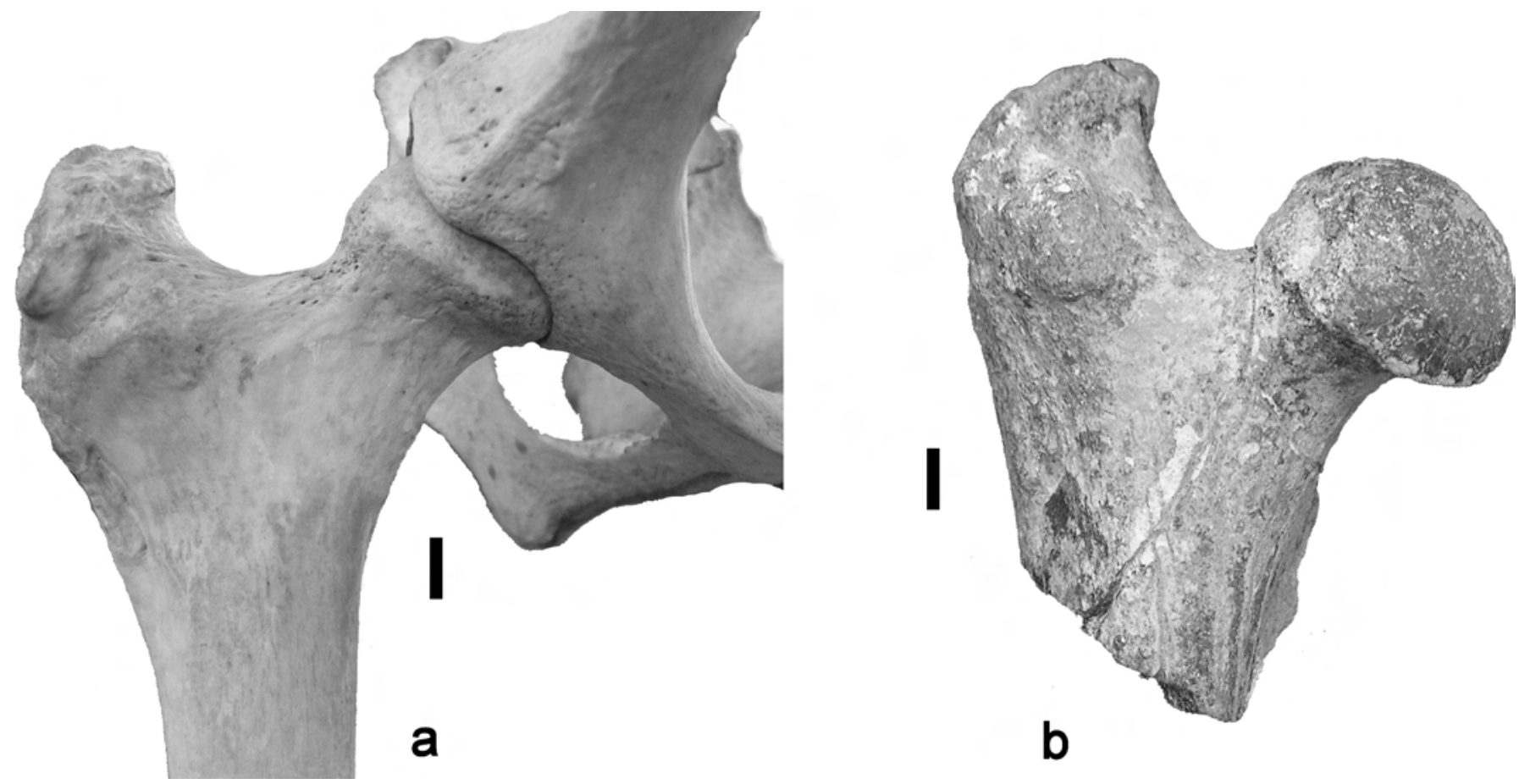

Figure 28. Femoral neck length in (a) Hippopotamus amphibius Linnaeus, 1758, right femur and (b) Libycosaurus petrocchii Bonarelli, 1947, right femur from Beglia, Tunisia. The femoral neck is long in hippos and short in anthracotheres (scale: $10 \mathrm{~mm}$ ).
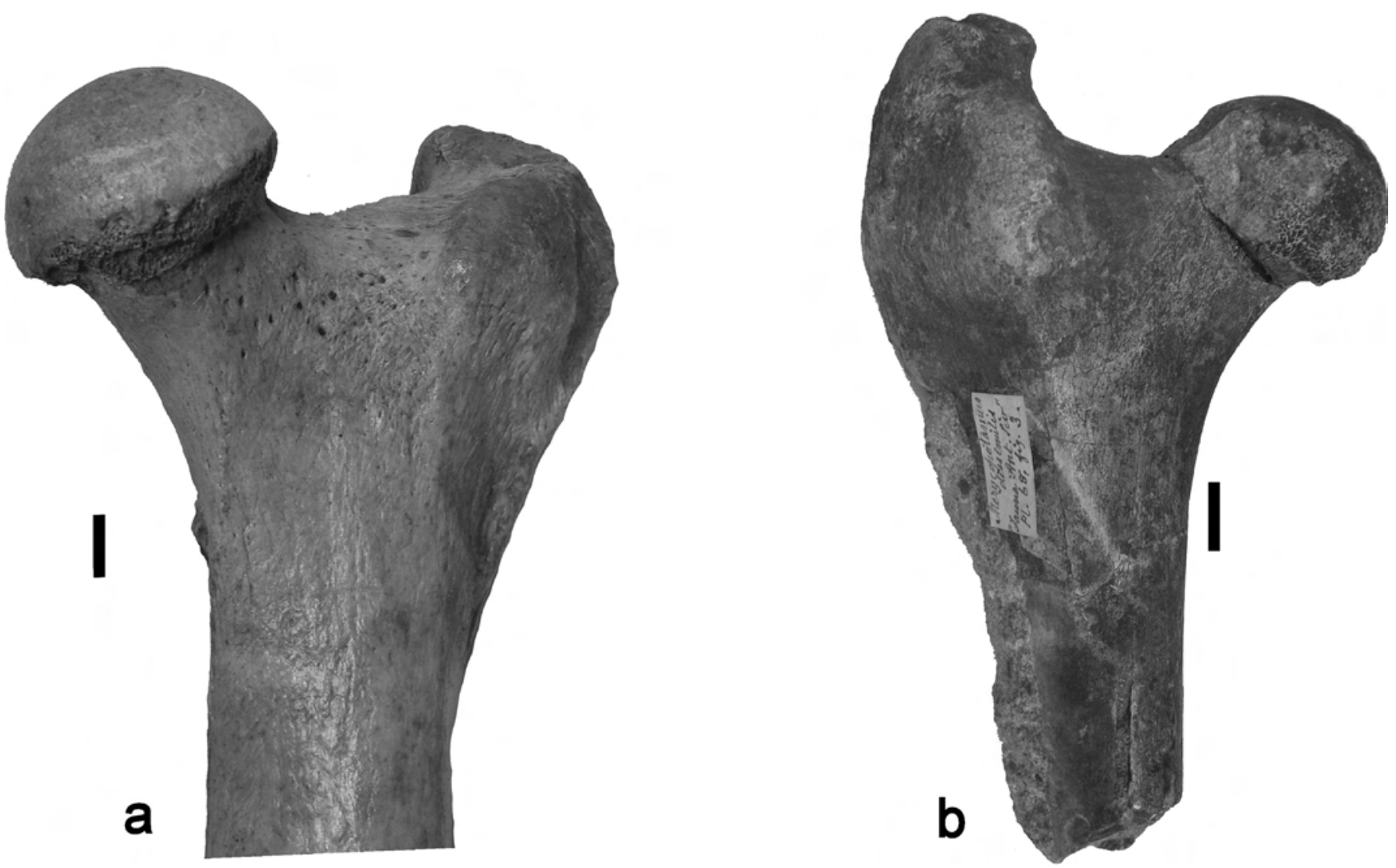

Figure 29. Projection of the greater trochanter above the femoral head in (a) Hippopotamus madagascariensis Guldberg, 1883, left femur, and (b) Merycopotamus Falconer \& Cautley, 1848, right femur from the Upper Siwaliks, India. The femora are oriented with the anterior border of the diaphyses parallel to each other. In hippos the trochanter terminates beneath the level of the head, whereas in anthracotheres it projects well above the head (scale: $10 \mathrm{~mm}$ ). 


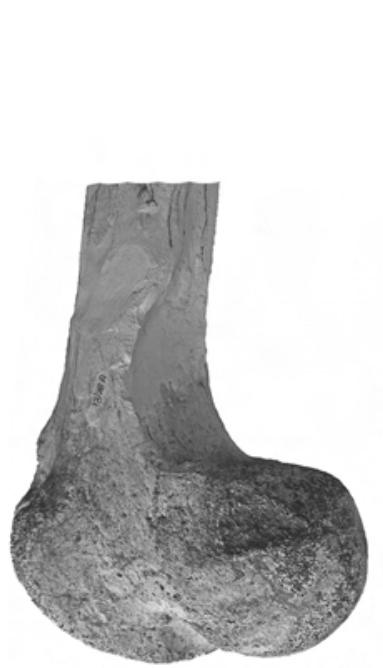

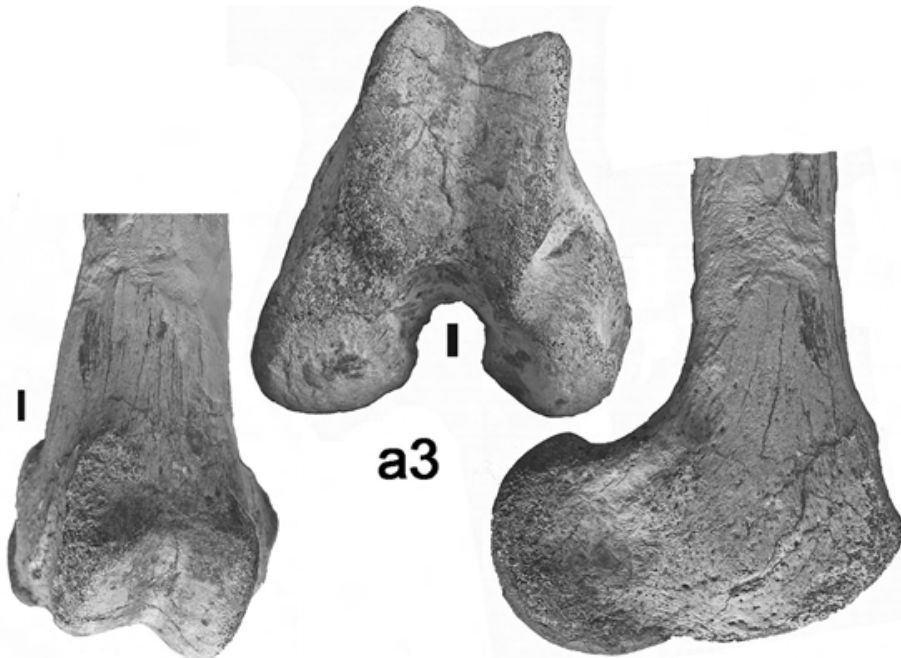

a4

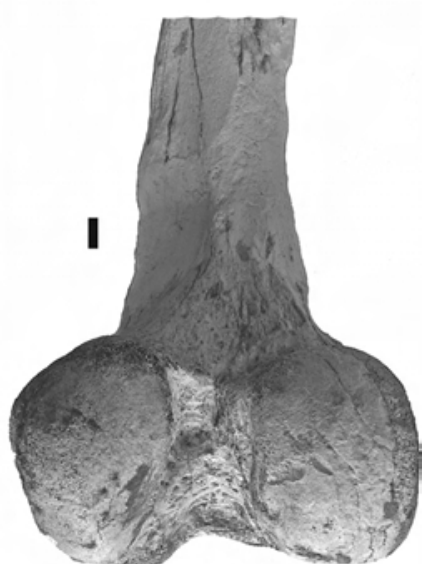

a5

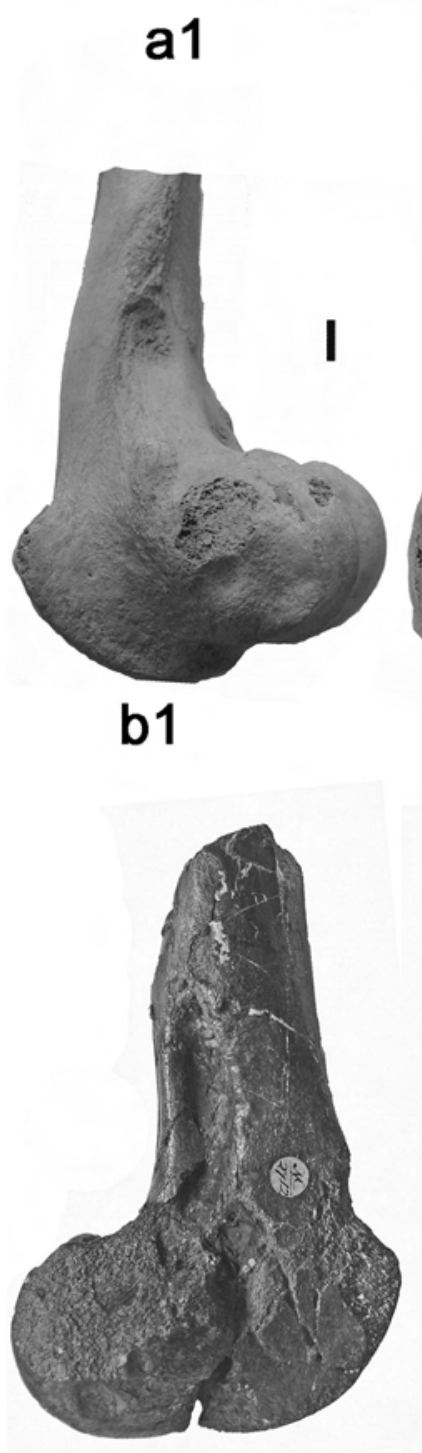

c1

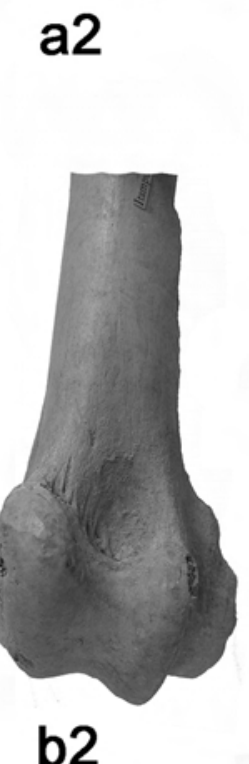

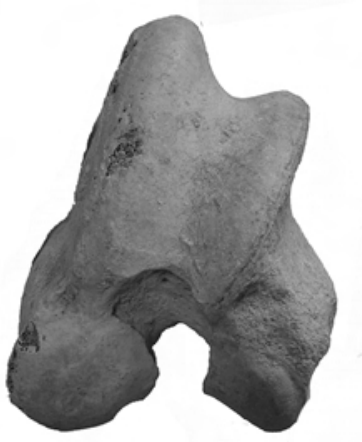

b3

b2

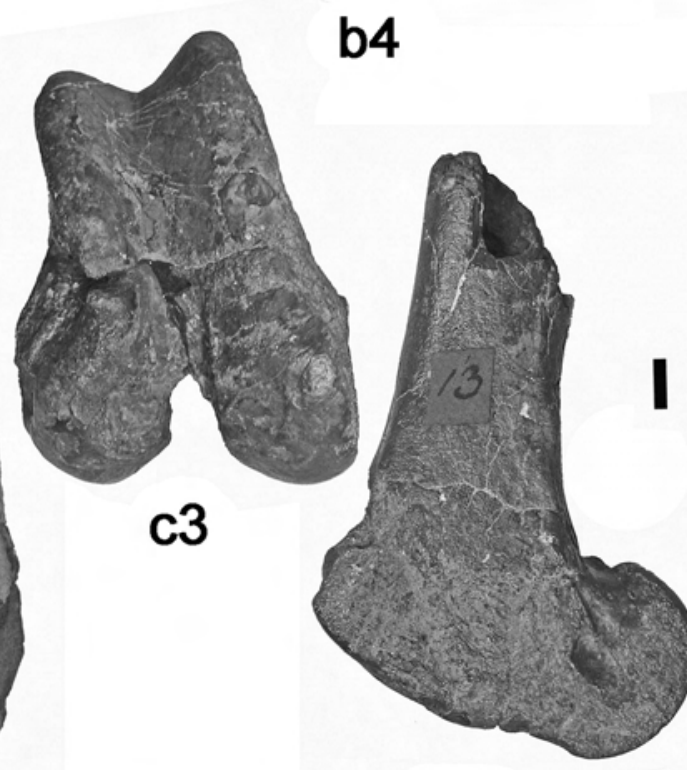

c4
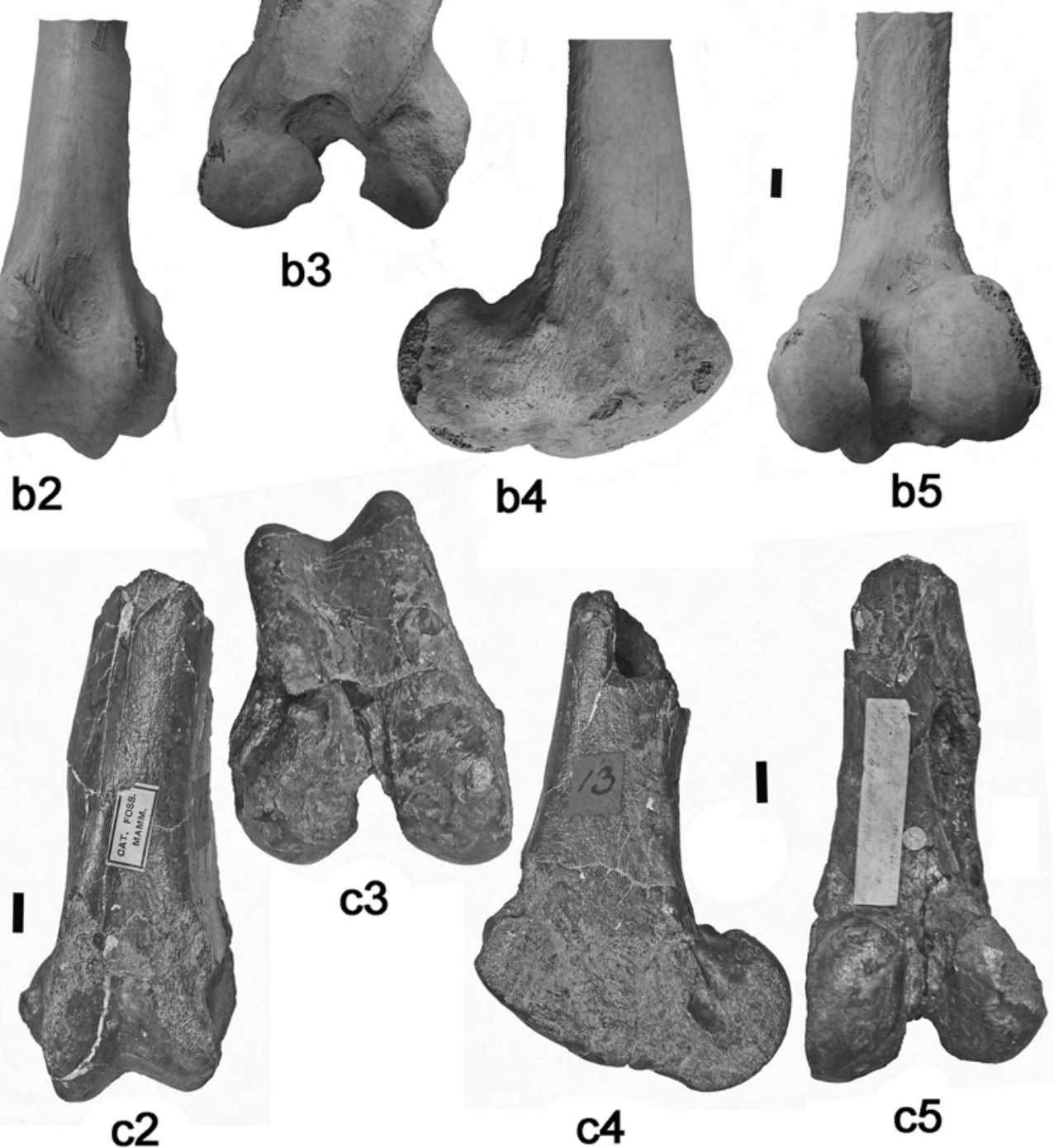

Figure 30. Distal femora of anthracotheres and hippos, (a) OMD 93'28, Brachyodus aequatorialis MacInnes, 1951, left femur from Auchas, Orange River Valley, Namibia, (b) NHM M 4953, Hippopotamus sp. left femur from Itampulu Vé, Madagasacar, (c) NHM M 2712, Merycopotamus dissimilis (Falconer \& Cautley, 1836), right femur from the Siwalik Hills, India (scale bar: $10 \mathrm{~mm}$ ). 


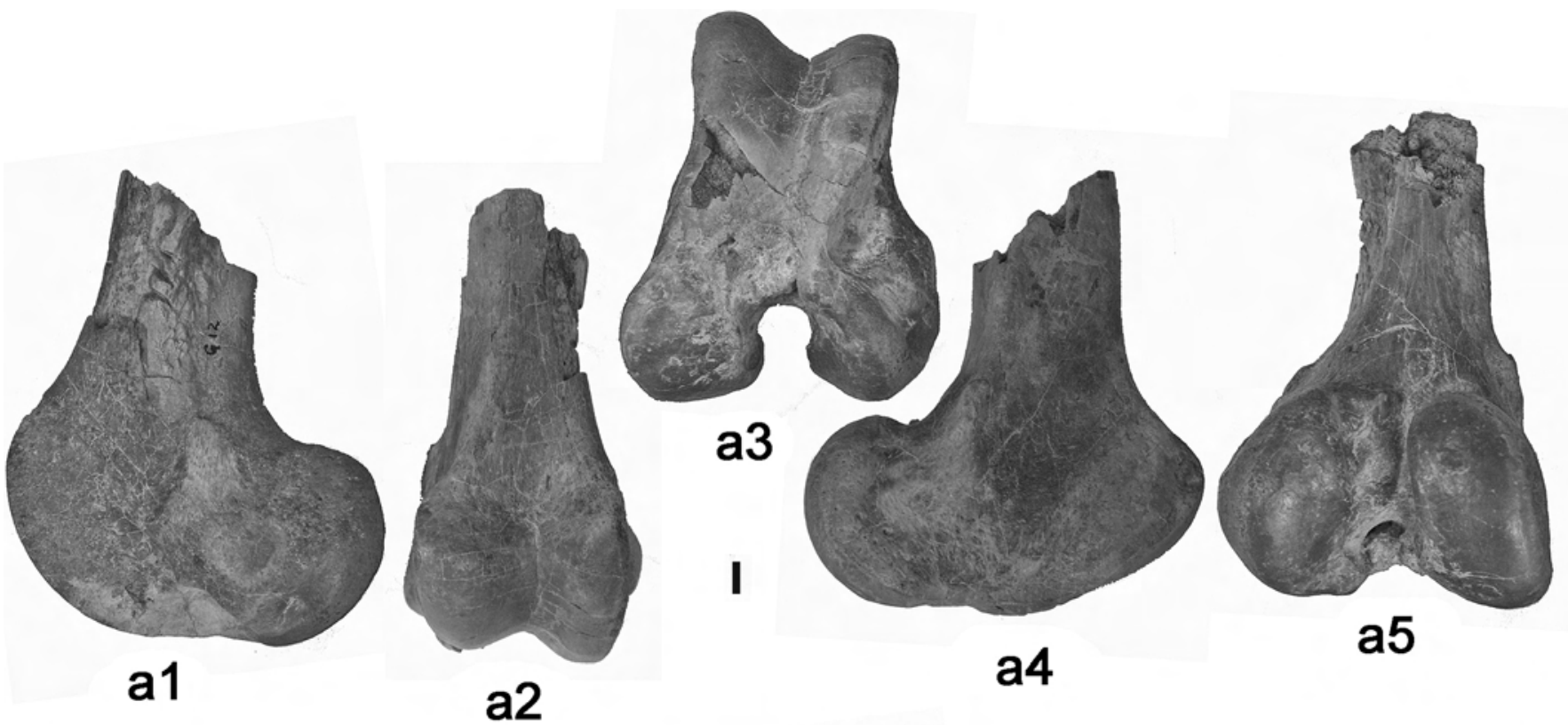

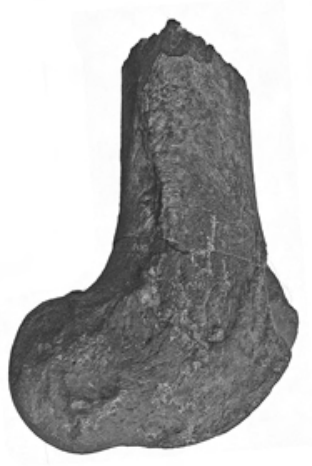

b1
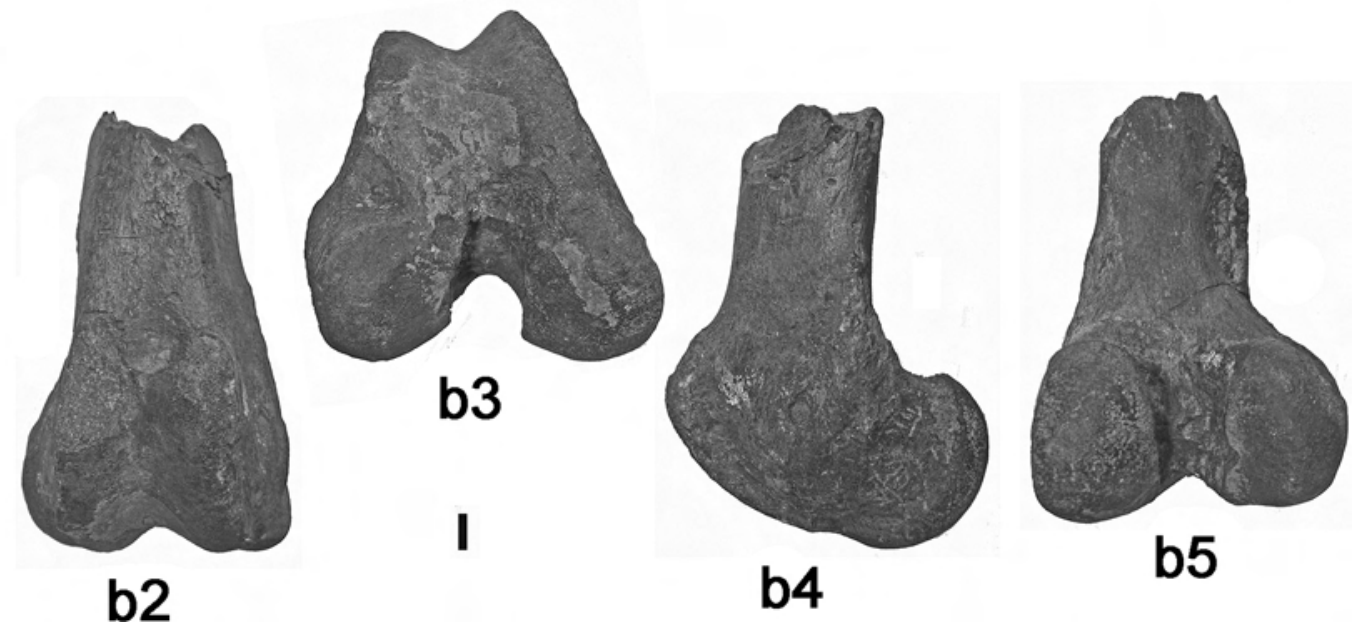

Figure 31. Distal femora of anthracotheres and hippos, (a) NHM G 12, Sivameryx africanus (Andrews, 1914), left femur from Gebel Zelten, Libya, (b) NHM M 17979, Merycopotamus dissimilis (Falconer \& Cautley, 1836), right femur from the Siwalik Hills, India (scale bar: $10 \mathrm{~mm}$ ).

oped than the lateral one, and the supratrochlear depression is shallow and slopes slightly laterally. The medial supratrochlear lip is low dorsally, although the specimen is abraded in this part which makes it difficult to interpret. However, the dorsal part of the lip was probably not very much higher than the lateral one. With the condyles placed horizontally, the trochlear groove is only slightly inclined. The popliteal fossa is shallow but extensive, and the fossa for the femoro-metatarsal ligament is deep and extensive, separating the articular surface of the trochlea from that of the lateral condyle. The two condyles are sub-equal in dimensions and the intercondyloid fossa is broad and has a wide transverse ridge separating the proximal and distal fossae for the cruciate ligaments. The posterior fossa for the cruciate complex is closed distally by a sharp edged ridge.
In overall morphology the Auchas anthracothere femur resembles that of Merycopotamus and Sivameryx, despite its considerably greater dimensions. The only significant difference is that the medial supratrochlear ridge is higher than the lateral one but the difference in development of these ridges is much less than it is in Hippopotamus.

NHM M 4953, a femur of Hippopotamus from Itampulu Vé, Madagascar, was studied because it is from a small species, its femur being about the same dimensions as that of Merycopotamus dissimilis described above (Fig. 30). The supracondyloid fossa is shallow and does not show any signs of overhanging walls. The bone surface in the fossa and its surroundings is roughened by low crests and fine tubercles. The medial trochlear lip is much higher and more inflated than the lateral one, as in Hippopotamus amphibius. The medial supratrochlear ridge is much higher 
and broader than the lateral one. The supratrochlear fossa is well developed and slopes laterally. The fossa for the femoro-metatarsal ligament is shallow and there is a gap between the articular surfaces of the trochlea and the lateral condyle. The popliteal fossa is weak, barely discernible. In this specimen, as in other hippo femora studied, the lateral condyle is considerably smaller than the medial one, such that when the condyles are posed horizontally, the trochlear gulley is more inclined than it is in Sivameryx from Gebel Zelten, Brachyodus from Auchas and Merycopotamus from the Siwaliks.

\section{Tibia}

The morphology of the proximal epiphysis of the tibia of hippos and anthracotheres (in particular that of Merycopotamus) are radically different (Fig. 32). In Hippopotamus, the medial articular surface is more expansive than it is in anthracotheres, extending anteriorly and laterally further than in the anthracothere. The lateral articular surface in contrast, is appreciably smaller in the hippo than in anthracotheres. Related to these articular differences, are the position and shape of the notch at the proximal end for the politeal and the peroneus tertius (femoro-metatarsal ligament) which in anthracotheres is narrow, close to the anterior tuberosity and opens more anteriorly than laterally, whereas in Hippopota$m u s$, it is considerably wider and opens laterally.

The proximal tibia of Merycopotamus dissimilis was already compared by Lydekker (1876) to those of hippos and suids. In proximal view the most striking difference between Merycopotamus and Hippopotamus concerns the relative sizes of the medial and lateral articulations for the femoral condyles. In the anthracothere, the two surfaces are subequal in dimensions, whereas in hippos the lateral articular surface is considerably smaller than the medial one, paticularly in its antero-posterior dimensions. As a result of this, the groove for the popliteal muscle and the femoro-metatarsal ligament opens antero-laterally in the anthracothere whereas it faces largely laterally in hippos. Furthermore the groove is relatively narrower in anthracotheres than in hippos. Linked to this morphology is the position of the fossae for the cruciate ligaments, which are located in the antero-posterior midline of the proximal surface in anthracotheres, whereas in hippos the anterior fossa is positioned well laterally from the midline, the posterior one being in the midline.

In Brachyodus aequatorialis from Gebel Zelten (NHM M 17) the two articular surfaces of the proximal tibia are subequal, the popliteal groove is narrow and opens antero-laterally, and the two fossae for the cruciate ligaments are aligned with the antero-posterior midline of the bone. The same conformation is seen in a specimen from Arongo Uyoma (NHM M 32726) and Rusinga (NHM M 32938) (Kenya) (Fig. 32).

\section{Interpretation of the musculo-tendinal system of the knee joint of anthracotheres}

The morphology of the distal femur and proximal tibia of bothriodonts stands out from the remainder of the suiform artiodactyls to such an extent that it suggests that their locomotor repertoires were markedly different. The great development in the femur of the supracondyloid fossa together with its extremely rugose denticulate surface indicates that the superficial flexor of the digits was relatively more powerful than in other suiform artiodactyls. The insertions for the gastrocnemials (lateral and medial heads) are well developed and extensive. This combination indicates that leaping or bounding were probably an important element of the locomotor repertoire of bothriodonts, analogous in ways to the gallop and jumping performed by equids. The fossa for the femoro-metatarsal ligament (peroneus tertius) in bothriodonts is deep and large, as in equids, whereas in suids and hippos its area of origin is relatively smaller. In horses this ligament comprises part of the lower limb stabilising mechanism that allows them to sleep in a standing position (Sisson \& Grossman, 1953). It also acts as a spring-like ligament automatically bringing the metatarsals into an extended position during locomotion. The position of the fossae for the cruciate ligaments in the anthracothere proximal tibia suggests a parasagitally constrained flexion-extension movement of the knee joint in anthracotheres, whereas in hippos the movement is strongly oblique to the parasagittal plane.

\section{Talus}

The proximal extension of the sinovial fossa in the talus (the digital fossa in Boisserie et al., 2005a, 2005b) is highly variable in artiodactyls. In general large artiodactyls such as Bos Linnaeus, 1758, and Syncerus Hodgson, 1847, have a fossa that extends proximally well into the region between the lateral and medial tibial articular facets, sometimes as far as the proximal extremity of the bone, whereas smaller artiodactyls tend to have a small extension proximally or none at all, although there are exceptions such as Capra Linnaeus, 1758. Thus a comparison between hippos on the one hand, both extant genera of which are large mammals, and Potamochoerus Gray, 1854, and Sus on the other, both of which are medium sized suids, would be expected to show allometric differences in sinovial fossa extension proximally. As soon as we include larger suids in the comparison, the distinction tends to break down, species such as Libycochoerus massai Arambourg, 1961, sometimes having a marked but not very deep extension.

Among the 22 tali of Brachyodus onoideus from the French Faluns (Dineur, 1981) that I studied 19 had no sign of a proximal extension of the sinovial fossa, and 

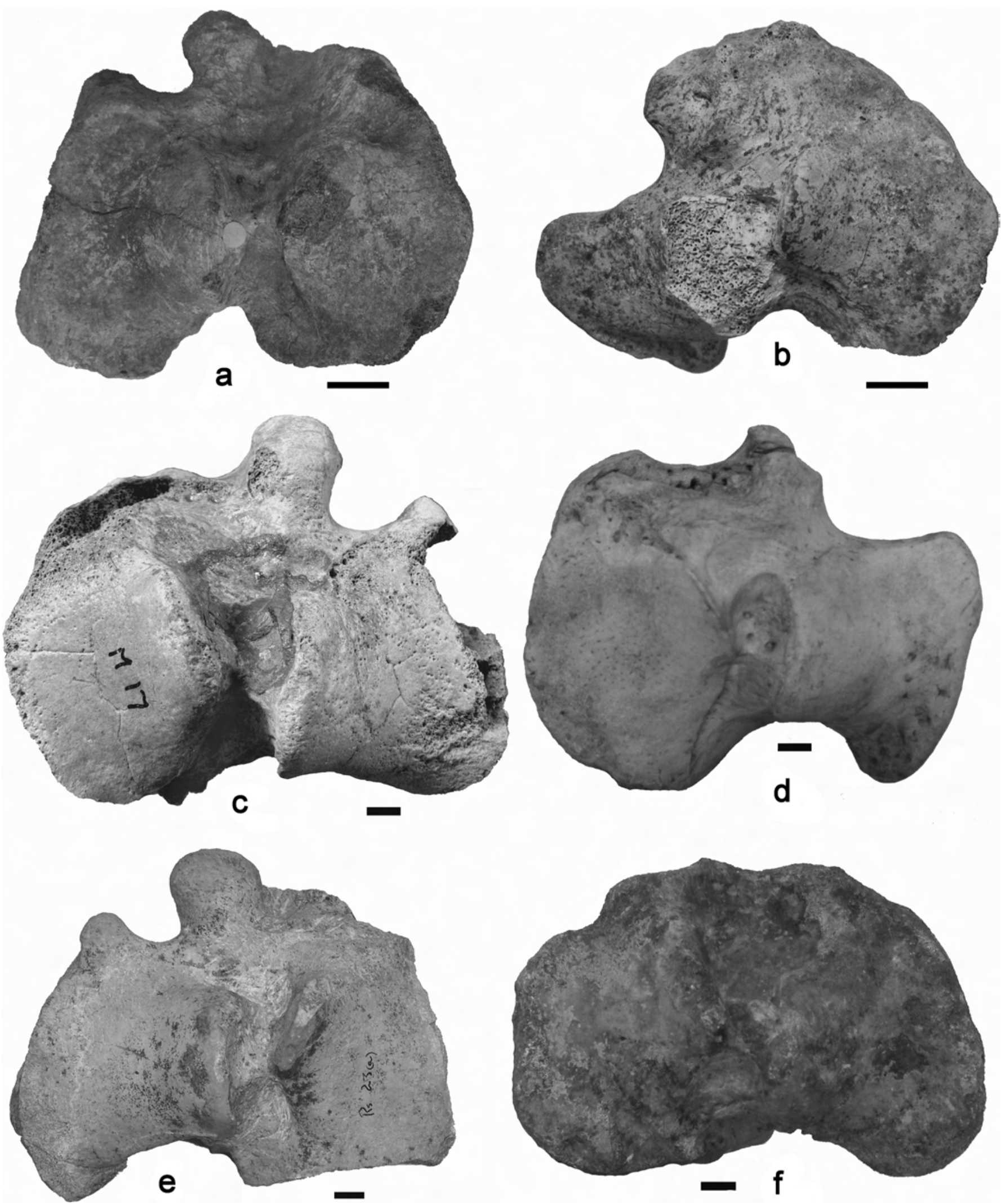

Figure 32. Proximal tibia of anthracotheres and hippos, (a) NHM M 17980, Merycopotamus dissimilis (Falconer \& Cautley, 1836), left tibia from the Siwalik Hills, India, (b) Hippopotamus sp. Itampulu Vé, Madagascar, (c) NHM M 17, Brachyodus aequatorialis MacInnes, 1951, left tibia from Gebel Zelten, Libya, (d) Hippopotamus amphibius Linnaeus, 1758, NHM, un-numbered specimen, right tibia, (e) NHM M 32938, Brachyodus aequatorialis, proximal left tibia from Rusinga (RS 23a) Kenya (note broken caudal part of medial articulation) (f) NHM M 32826, Brachyodus aequatorialis, damaged right tibia from Arongo Uyoma, Kenya (scale bar: $10 \mathrm{~mm}$ ). 
three had a shallow roughened area between the lateral and medial articulations for the tibia, somewhat similar to the condition in the suid Libycochoerus massai. Boisserie et al. (2005a) scored the proximal extension as present in the species Brachyodus aequatorialis but it is absent in the Egyptian and Namibian specimens attributed to the closely allied species Brachyodus depereti Fourtau, 1918 (Fourtau, 1920, Fig. 55; Pickford, 2003, Pl. 3). Although MacInnes (1951) did not illustrate the talus of this species, in the description he made no mention of the existence of the proximal extension of the sinovial fossa, although he did say that the talus was «similar in form to that of a hippopotamus, though distinctly more elongate». My own observation of tali of Brachyodus aequatorialis from Rusinga, Kenya, shows no evidence of the anterior extension of the sinovial fossa, and there is none in specimens from Gebel Zelten (Libya), Wadi Moghara (Egypt) and Grillental (Namibia). Its absence in another closely related species Brachyodus onoideus from Europe (Zbyszewski, 1949, Pl.
10) indicates that it has probably been incorrectly scored by Boisserie et al. (2005a). The value of this character for phylogenetic analysis is thus minimal, perhaps worthless without more precise definition.

Examination of anthracothere and hippopotamid tali reveals that they are not particularly similar to each other, as has often been assumed in the past. Similarities exist, but that is because they are Suiformes, but their detailed anatomy and proportions diverge significantly (Fig. 33, 34). For example, tali of anthracotheres such as Brachyodus usually possess a prominent projection on the lateral side. Most hippopotamids do not have a comparable protuberance, or if they do it is of low stature. The tibial trochleae of anthracothere tali are of uniform width throughout their extent, whereas hippo tali broaden abruptly laterally towards their anterior proximal extremity and have an extensive swelling of bone lateral to this broadening. The distal tibia shows concordant differences in morphology. The length-breadth proportions of the tali are extremely

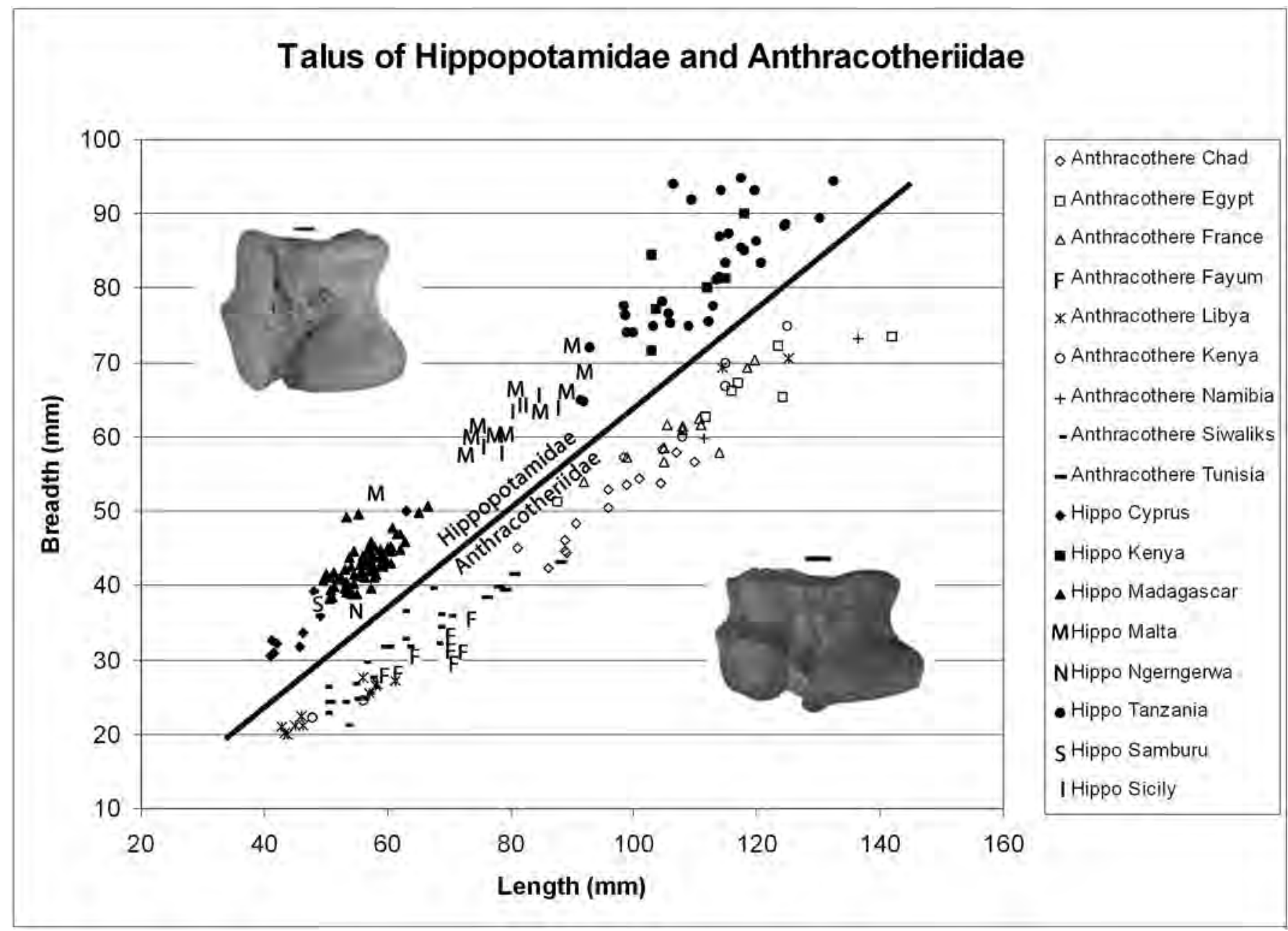

Figure 33. Length-breadth relationships of 102 anthracothere (below the sloping line) and 142 hippopotamid tali (above the line) from many different localities and time periods. All hippopotamid tali, including those of Kenyapotamus Pickford, 1983, are broader relative to length than all anthracothere tali, regardless of the overall dimensions or the geological age of the specimens measured. (Left tali illustrated are in anterior view: proximal is to the right) (scale $10 \mathrm{~mm}$ ). 


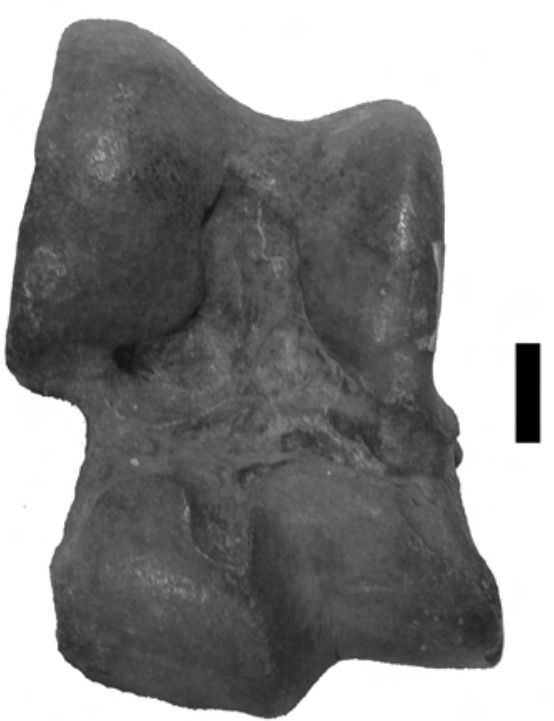

a

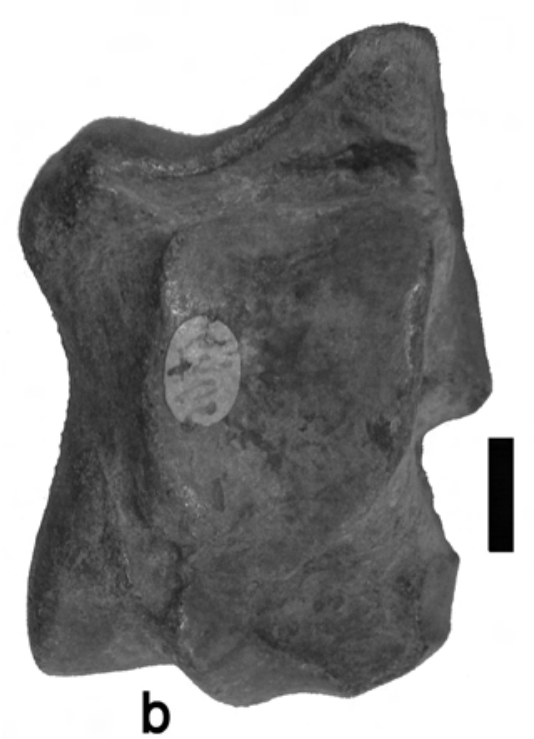

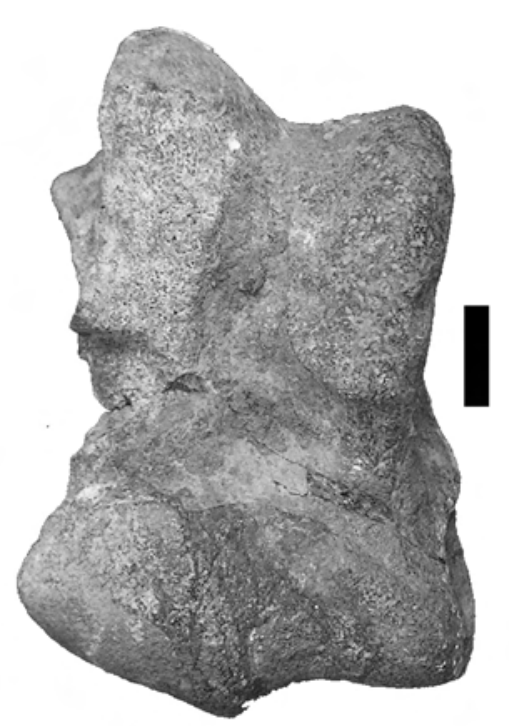

C

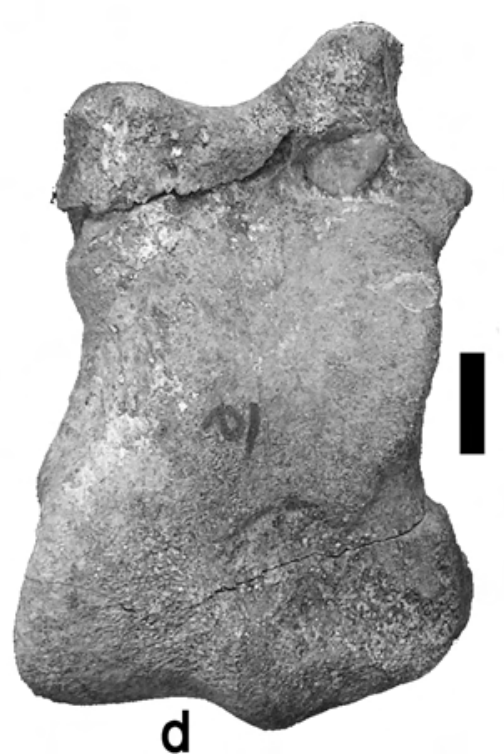

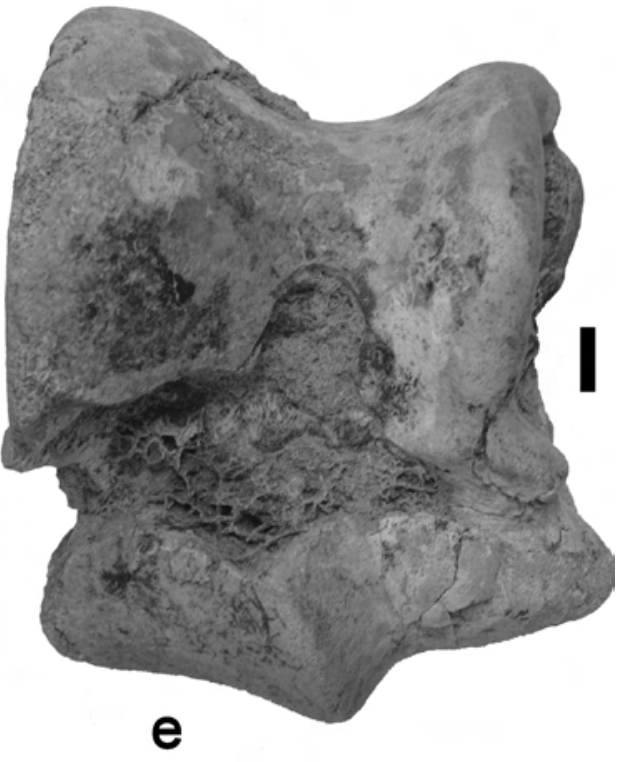

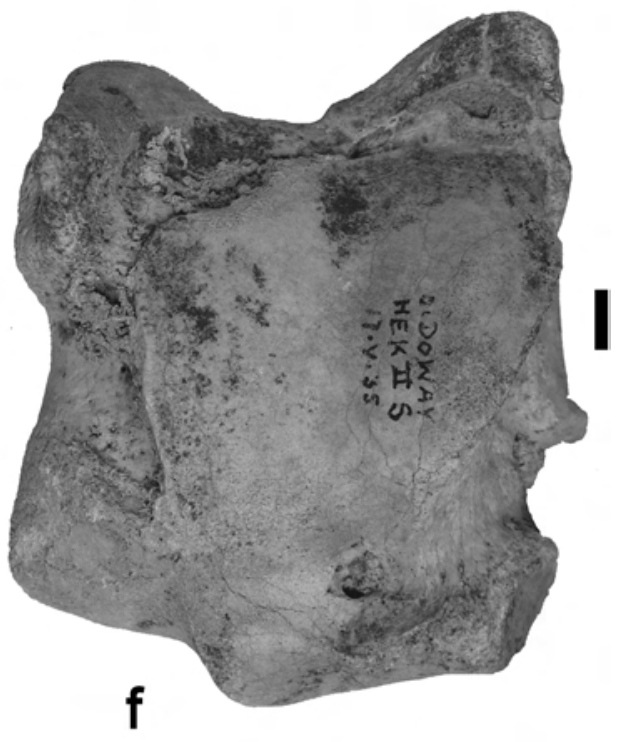

Figure 34. Comparison of tali of (a, b) Merycopotamus dissimilis (Falconer \& Cautley, 1836), left talus from the Upper Siwaliks, India, images reversed; (c, d) Libycosaurus petrocchii Bonarelli, 1947, left talus from Locality 6, Beglia, Tunisia, images reversed and (e, f) Hippopotamus sp. right talus from HEK II, Olduvai, Tanzania (scale: $10 \mathrm{~mm}$ ).

different, with those of anthracotheres being narrow and elongated, somewhat like those of suids, whereas those of hippos are shorter and broader. The angulation of the joint surfaces is different, with hippos having more oblique cuboid and navicular surfaces than those of anthracotheres. In anterior view the angle between the tibial and navicular-cuboid trochleae is more accented in the hippo than in the anthracothere. These differences translate into different rotatory trajectories of the foot relative to the tibia during locomotion, with anthracotheres having their feet oriented slightly beneath the body, whereas hippos have the feet closer to the sagittal plane.

\section{Navicular and cuboid}

The cuboid of Brachyodus aequatorialis possesses two prominent internal, almost horizontal facets for articulation with the navicular, such that in anterior and posterior views, the two bones imbricate with each other for about a quarter of their width. In hippos in contrast the facets are small, often reduced to one small sloping facet, or to two vertically oriented facets, so that when articulated there is little imbrication of the two bones. The latter combination in hippos is closer to that of suids and palaeochoerids than to that of anthracotheres. This translates into 
a more stabilised talar/navicular-cuboid joint in anthracotheres than in hippos.

\section{Metapodials}

The distal ends of the metapodials of palaeochoerids do not have keels on the dorsal surface, unlike those of Tayassuidae and Suidae which do (Fig. 35) (Kowalevsky, 1873, 1874). The Sansan fossils attributed to Choerotherium (now classified in Choeromorus after being called Taucanamo for half a century) illustrated by Kowalevsky (1874, Pl. 7, Fig. 6) show this clearly (confirmed by M. Orliac, pers. comm.). The grouping of Doliochoerus and Palaeochoerus with Tayassuidae and Suidae respectively, by Boisserie et al. (2005b, Fig. 7) is thus inconsistent with the anatomy. It should be noted that the metacarpals of Palaeochoerus illustrated by Kowalevsky (1874, Pl. 7,
Fig. 7) are in fact those of Hyotherium (the same confusion of names occurred with the large skull from St-Gérandle-Puy for a long time identified as Palaeochoerus). This mis-identification has misled researchers for more than 150 years and continues to do so, even though the misattribution was pointed out more than 30 years ago by Ginsburg (1974). Another difference between the metapodes of hippos and anthracotheres concerns the proximo-distal length of the metapodials. In metacarpals and metatarsals which have comparable dimensions of the articular surfaces, the length of the diaphysis is considerably greater in anthracotheres than in hippos.

\section{Summary of post-cranial evidence}

In conclusion, Libycosaurus, which has recently been interpreted to represent the sister-group of hippos (Bois-
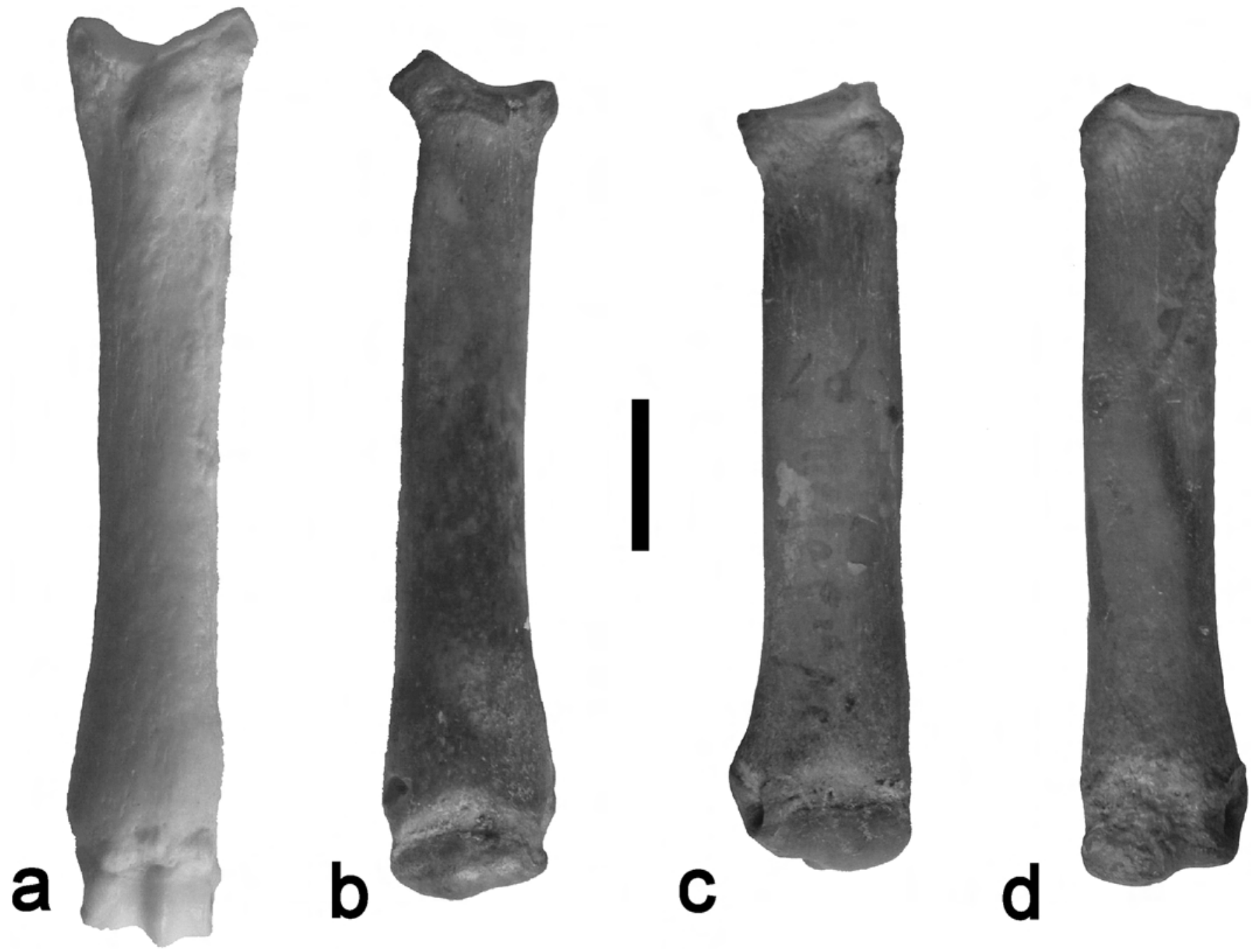

Figure 35. Anterior views of suoid axial metapodials showing presence of anterior keel in the distal epiphysis in tayassuids (a) and the lack of anterior keel in palaeochoerids (b-d); (a) Tayassu pecari (Link, 1795), (b) Choeromorus mammillatum Filhol, 1851, from Sansan, France, (c) and (d) Palaeochoerus typus Pomel, 1847, from St-Gérand-le-Puy, France (scale: 10 mm). 
serie et al., 2005a, Fig. 2) possesses cervical, humeral, femoral, tibial, ankle and metapodial anatomy that does not accord with the scenario of a close phylogenetic relationship between the two (Fig. 36). To this should be added some life history (growth) parameters such as ankylosis of the radio-ulna in hippos, and non-fusion of these bones in Merycopotamus and other anthracotheres. In brief, anthracotheres possessed long limbs, shallow thoracic cag-

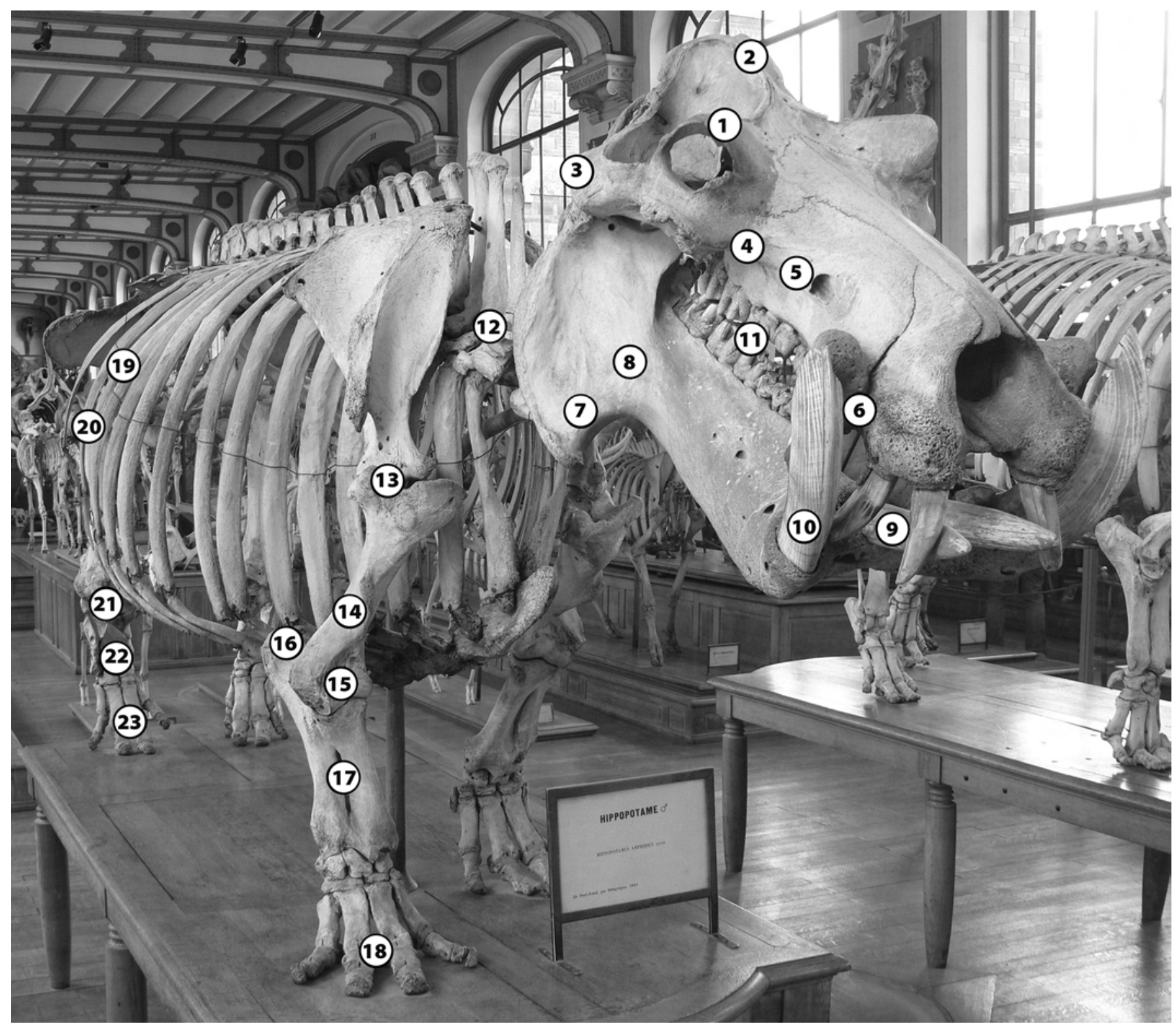

Figure 36. Summary of cranio-dental and skeletal characters discussed in this paper. Characters 1 and 7 (descending plate of mandible and elevated orbits) have been interpreted by several authors as synapomorphies of Libycosaurus Bonarelli, 1947, and Hippopotamus Linnaeus, 1758, but they are not homologous. Characters 1, 3, 4, 5 and 6 represent morphologies which are different in hippos on the one hand, and Merycopotamus Falconer \& Cautley, 1848 ; and Libycosaurus on the other. Characters 9 and 10 (lower incisors and canines) were interpreted by some authors to be apomorphies shared by Libycosaurus petrocchii and Hippopotamus but the description for Libycosaurus is erroneous. The cheek teeth of anthracotheres and hippopotamids (character 10) differ markedly from each other (Libycosaurus even possesses an accessory premolar unique among artiodactyls). Character 19 (pelvis) has been said to link anthracotheres and hippopotamids, but the morphological similarities are possibly due to allometric scaling in large suiforms, and if so are not homologous in the two groups. Character 22 (talus breadth / length ratio) is derived in hippopotamids, but is primitive in anthracotheres, palaeochoerids, suids, sanitheriids and tayassuids. Characters 18 and 23 (absence of anterior keel on distal epiphyses of the axial metapodials and the corresponding morphology of the anterior epiphysis of the 1st phalanges) are plesiomorphic in anthracotheres, palaeochoerids and hippopotamids. In all other post-cranial characters listed, hippos are different from anthracotheres, indicating highly divergent locomotor repertoires. 
es, and long necks (Kowalevsky, 1873; Geais, 1934) (Fig. 37) whereas hippos have short legs, a deep barrel-shaped thoracic cage and a short neck (Blainville, 1846) (Fig. 2). These findings run counter to the observation of Lihoreau (2003) that apart from the talus and metapodials, the postcranial bones of Libycosaurus and Hippopotamus cannot be distinguished from each other.

\section{Scenario of locomotion and habitat of bothriodont anthracotheres}

Taking into account the great development of the supracondyloid fossa of the femur, which houses the attachment of the digital extensors, the subequal dimensions of the trochlear lips, the relatively great depth of the fossa for the femoro-metatarsal ligament, and the lesser inclination of the trochlear groove, it is suggested that these anthracotheres were adapted for a bounding type of locomotion (Fig. 38). The closest analogy that springs to mind regarding the depth and extent of the supracondyloid fossa is that of equids, which also have a large and deep fossa with overhanging walls. Springing and bounding are activities unknown to occur in hippopotamids, which don't even step over low obstacles in their path.

Given that bothriodont remains are almost always found associated with lignites, paludal clays and fluviatile deposits, it is likely that they lived close to or in shallow water bodies. The fact that their limbs are elongated suggests that for most of the time they tended to keep their head and body out of the water, with only the lower limbs submerged (Fig. 38) a completely different strategy from that of hippopotamids, which have short limbs, and habitually keep the body submerged beneath the surface when in deep enough water.

At present there are several artiodactyl species that live preferentially in such settings, deriving not only adequate food resources from the water bodies and their surroundings, but also a certain degree of security from terrestrial predators (Fig. 38). Such species which spend most of their lives in shallow water, are difficult to take by surprise, and when approached by predators, can bound away through the water with much greater ease than carnivores (Fig. 38). In India, the closest analogy to Merycopotamus dissimilis in terms of overall body size and limb proportions is provided by the Sambar [Cervus unicolor (Kerr, 1792)] which spends most of its life in shallow water and the banks close to such water bodies. In South America, an analogous artiodactyl is the Swamp Deer [Blastocerus dichotomus (Illiger, 1815)]. In Africa, the closest analogy to Sivameryx africanus (Andrews, 1914) in terms of body size, is the reduncine bovid, the Lechwe (Kobus leche Gray, 1850) which has similar habitat requirements to the Sambar, but tends to live in large herds. The Sitatunga (Tragelaphus spekei Speke, 1863) is another African antelope that spends most of its time in water, but unlike the Lechwe and the Sambar, it often submerges its body when threatened or surprised, although it too will frequent shallow water bodies in which case its body is emergent.

Smaller anthracotheres, such as Afromeryx zelteni Pickford, 1991, which was about the size of a wild boar [Sus scrofa (Linnaeus, 1758)] but with more elongated legs and feet, may have occupied niches similar to those of the Chinese Water Deer [Hydropotes inermis (Swinhoe, 1870)] and the Water Chevrotain [Hyemoschus aquaticus (Ogilby, 1840)]. These two ruminants live near water bodies in dense forest. They spend much of their time out of the water but when threatened or surprised will plunge into water to escape, often remaining submerged for considerable periods of time during which they breath every few minutes by poking the nostrils up through floating vegetation.

In India, a suitable habitat and ecological analogy for the larger bothriodonts, such as Brachyodus onoideus (Gervais,

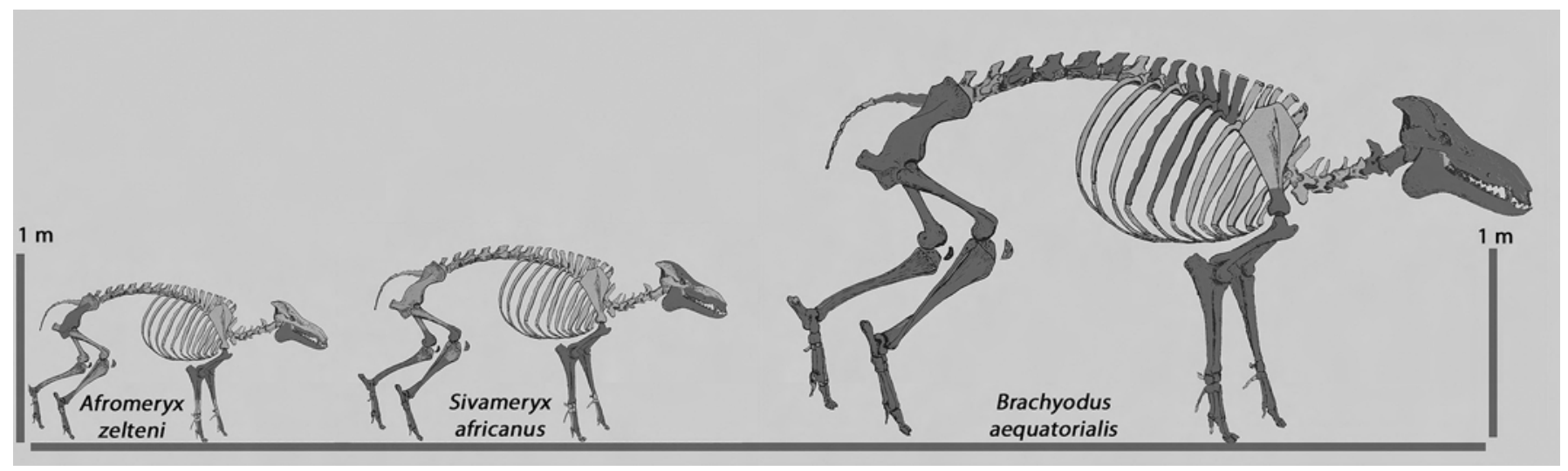

Figure 37. Reconstructions of the skeletons of three species of bothriodont anthracotheres: Afromeryx zelteni Pickford, 1991, Sivameryx africanus (Andrews, 1914), and Brachyodus aequatorialis MacInnes, 1951, based on fossils from Gebel Zelten, Libya, and the Winam Gulf region, Kenya, using the reconstruction of the skeleton of Elomeryx borbonicus Gervais, 1852 , by Geais (1934) as a template. Note the elongated limbs and the humerus emergent beneath the rib cage. 


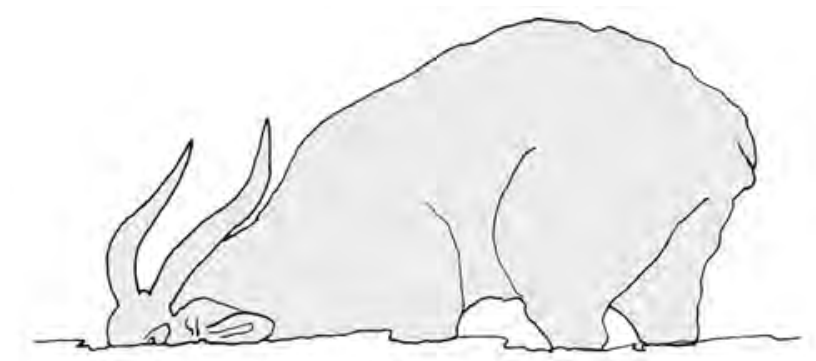

a
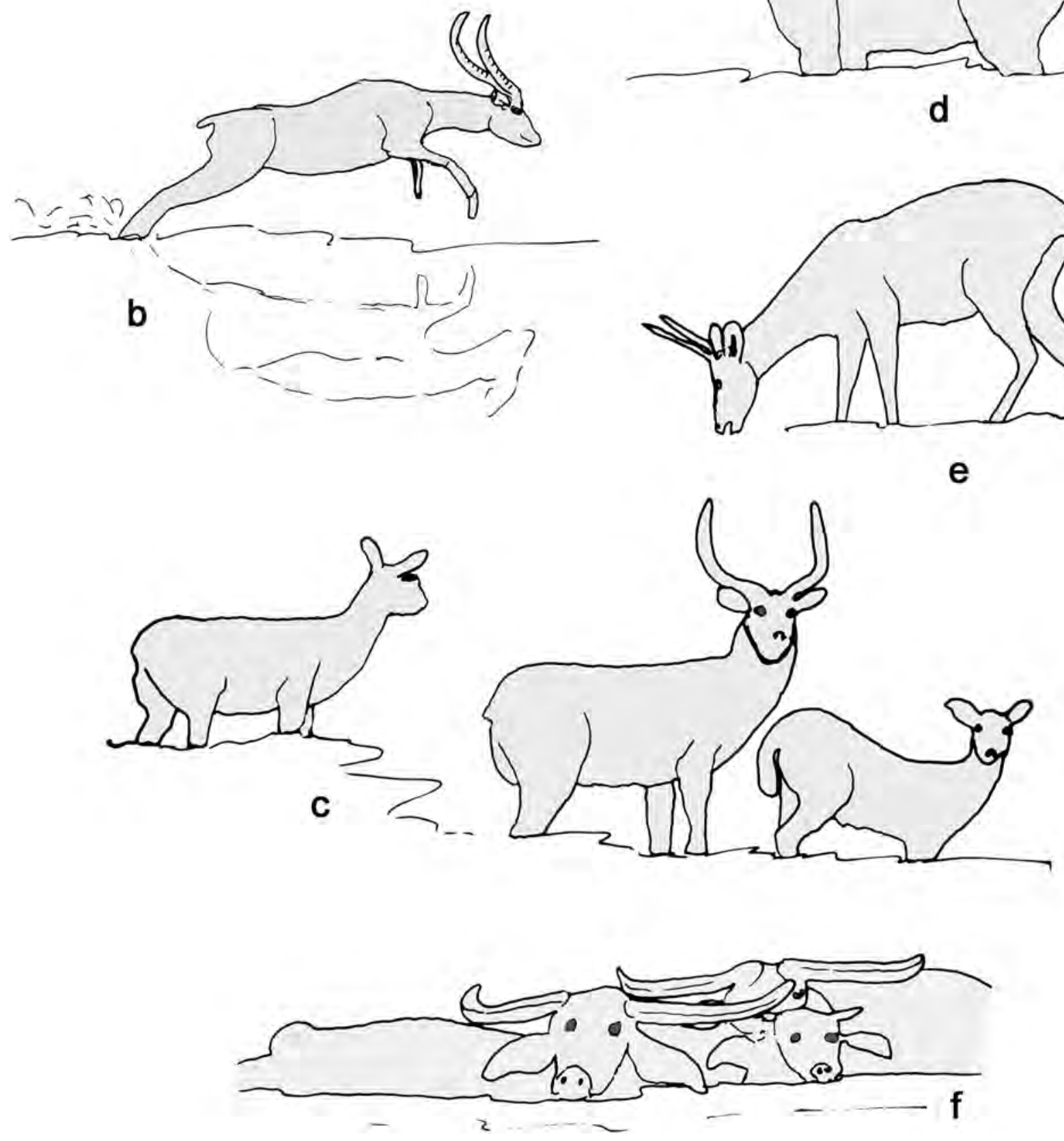

Figure 38. Extant aquaphilous ruminants, (a) Sitatunga (Tragelaphus spekei Speke, 1863) feeding on subaqueous plants in shallow swamp,(b) Lechwe [Kobus leche (Gray, 1850)] male bounding through shallow water (note the splayed front legs, a typical posture adopted during water-bound bounding locomotion), (c) Lechwe (Kobus leche) male and two females in shallow water, (d) Sambar [Cervus unicolor (Kerr, 1792)] male in shallow swamp, (e) Swamp Deer [Blastocerus dichotomus (Illiger, 1815)] in shallow swamp, (f) Water Buffalo (Bubalus bubalis Linnaeus, 1785) mixed herd lying in shallow water. 
1859), which are over a metre tall at the shoulder, is the Water Buffalo (Bubalus bubalis Linnaeus, 1758) which spends much time half submerged in water and mud (Fig. 38).

\section{SUMMARY OF THE DEBATE ABOUT HIPPOPOTAMID ORIGINS}

Table 4 summarises the debate about hippopotamid origins. It is clear that the most contentious hypothesis is the one in which hippos are considered to be derived from anthracotheres, with many proponents for it and an almost equal quantity of contestors against it.

\section{TAPHONOMICAL AND ENVIRONMENTAL CONSIDERATIONS}

Boisserie et al. (2005a, 2005b) suggested that hippos, anthracotheres and whales probably had affinities for

$\begin{array}{lll}\text { Hypothesis } & \text { First mention } & \text { Supported by } \\ \text { 1. Anthracotheriidae } & \text { Falconer \& } & \text { Lydekker, 1876 } \\ & \text { Cautley, 1836 } & \text { Huxley, 1871 } \\ & \text { Colbert, 1935 } \\ & \text { Gentry \& Hooker, 1988 } \\ & \text { Van der Made, 1999 } \\ & \text { Boisserie } \text { et al, 2005a, } \\ & & \text { 2005b Boisserie, 2006 } \\ & & \text { Pearson, 1929 } \\ & \text { Theodor \& Foss, 2006 }\end{array}$

2b Cebochoeridae

Pearson, 1927

Pearson, 1929

3. Suidae (sensu lato)

Matthew, 1934** No-one

4. Tayassuidae (sensu stricto)

Matthew, $1934 \quad$ No-one

5. Palaeochoeridae $* * *$
Pickford, 1983

aquatic environments right from the outset of their evolution 50-60 million years ago (Boisserie et al., 2005a, 2005b). The earliest known Hippopotamidae (Kenyapotaminae) are seldom found in sediments deposited under aquatic conditions (Pickford, 2007). Most have been found in palaeosols, and only the Tunisian material aged ca 12$10 \mathrm{Ma}$ is associated with fluvial deposits, and in contrast to anthracotheres, their fossils are rare therein. Despite the abundance of lacustrine, fluvial and paludal deposits in Africa ranging in age from 23 million to about 8 million years, very few hippo fossils have been found in them. Yet in deposits that accumulated later than 7 million years ago, virtually every African waterlain deposit is replete with hippo remains. The conclusion that I draw is that prior to 7 Ma hippos were not particularly potamophile, certainly not as amphibious as extant hippos, a suggestion that finds support from studies by Harris (1991) and Weston (2003) who showed that even some of the Late Miocene hippopotamines were not as well adapted to aquatic environments as the extant Hippopotamus is. As soon as hippos occupied fluvio-paludal and shallow lacustrine envi-

Theodor \& Foss, 2006

\section{Contested by}

Stehlin, 1899-1900

Pearson, 1929

Matthew, 1929

Pickford, 1983

Theodor \& Foss, 2006

Geisler \& Uhen, 2006

Colbert, 1935

Pickford, 1983

Boisserie et al, 2005a, 2005b

Colbert, 1935

Pickford, 1983

Boisserie et al, 2005a, 2005b

Colbert, 1935
Pickford, 1983

Boisserie et al. 2005a, 2005b

Colbert, 1935

Pickford, 1983

Boisserie et al. 2005a, $2005 b$

Pickford \& Morales, 1989
Boisserie et al. Cranial, dental 2005a, 2005b, but no and postcranial adequate test has been morphology performed

\begin{tabular}{|c|c|}
\hline Evidence for & Evidence against \\
\hline $\begin{array}{l}\text { Descending angle } \\
\text { of mandible, raised } \\
\text { orbits, pelvic } \\
\text { morphology, some } \\
\text { dental features*. }\end{array}$ & $\begin{array}{l}\text { Major differences in } \\
\text { virtually all skeletal an } \\
\text { dental morphology }\end{array}$ \\
\hline $\begin{array}{l}\text { Dental and cranial } \\
\text { features }\end{array}$ & $\begin{array}{l}\text { Some differences in } \\
\text { cranial and dental } \\
\text { morphology }\end{array}$ \\
\hline $\begin{array}{l}\text { Dental and } \\
\text { basicranial features }\end{array}$ & $\begin{array}{l}\text { Some differences in } \\
\text { cranial and dental } \\
\text { morphology }\end{array}$ \\
\hline $\begin{array}{l}\text { General features } \\
\text { of the skull and } \\
\text { dentition }\end{array}$ & $\begin{array}{l}\text { Many differences in the } \\
\text { skull and post-cranial } \\
\text { bones }\end{array}$ \\
\hline $\begin{array}{l}\text { General features of } \\
\text { the skull and teeth }\end{array}$ & $\begin{array}{l}\text { Many differences in } \\
\text { dentition, skull and } \\
\text { post-cranial skeleton }\end{array}$ \\
\hline $\begin{array}{l}\text { Cranial, dental } \\
\text { and postcranial } \\
\text { morphology }\end{array}$ & $\begin{array}{l}\text { Minor differences } \\
\text { in cranial and dental } \\
\text { morphology }\end{array}$ \\
\hline
\end{tabular}

\section{Evidence for} morphology, some 
ronments on a semi-permanent or permanent basis during the Late Miocene, their remains were from then onwards frequently preserved for the simple reason that they were now inhabiting the environments where waterlaid sediments were accumulating, thereby greatly enhancing the chances of their bones being preserved as fossils. Thus, the fossil and taphonomic evidence points to a relatively recent development of obligate potamophily and amphiby in hippos, and certainly not to one dating from the Palaeocene or Eocene. This finding indicates that the few cranial similarities between extant hippos and Libycosaurus noted by Boisserie et al. (2005a, 2005b) are likely to be due to the fact that both were amphibious, rather than to proximity of descent. Neither Saotherium nor Archaeopotamus show the derived amphibious morphology of the cranium that occurs in Hippopotamus and Hexaprotodon among the hippos on the one hand, and the independently derived morphology observed in Libycosaurus and Merycopotamus among the anthracotheres, on the other.

\section{TESTING THE PALAEOCHOERID AND ANTHRACOTHERE HYPOTHESES OF HIPPOPOTAMID ORIGINS}

Because anthracotheres are extinct, molecularists are unable to test the hypothesis of Boisserie et al. (2005a, 2005b) that the anthracotheres represent the phylogenetic link between whales and hippos. It is doubly unfortunate that the proposed sister-group of hippos in the palaeochoerid hypothesis is also extinct, meaning that molecular biologists have no way of testing which one of the hypotheses is more «robust». This means that the only source of information must come from the fossil record. Given the available dental, cranial and post-cranial data, I conclude that the most likely hypothesis of hippo origins is one in which Palaeochoeridae or something close to them played a significant role, leaving the anthracotheres as a more distantly related group of artiodactyls. This does not necessarily mean that anthracotheres were not related to cetaceans, but does imply that if they were, then they went extinct without issue. As this manuscript was nearing completion, work by Theodor \& Foss (2006) and Geisler \& Uhen (2006) was published, suggesting that anthracotheres are not closely related to either whales or hippos. The few resemblances in cranial morphology identified by Boisserie et al. (2005a, 2005b) in support of their hypothesis of sister-group relationships between hippos and anthracotheres are better explained by convergence, hippos eventually coming to inhabit the same kind of environment as anthracotheres, and thus developing weakly comparable cranial osteological adaptations such as raised orbits and high external auditory meatus, but retaining clear dental and post-cranial evidence of their palaeochoerid-like ancestors.

\section{UPDATE OF ASPECTS OF THE PALAEOCHOERID HYPOTHESIS OF HIPPOPOTAMID ORIGINS}

The hypothesis of derivation of the hippopotamids from Palaeochoeridae needs to be updated. A relatively minor change is that I agree that Xenohyus is a suid and should be removed from further consideration in the quest for hippo origins. It sports a pentacone on the M3/, has a tricuspid P4/, and a distal cusplet on the I1/. These features align the material with the genus Hyotherium, a suid, and distance it from palaeochoerids. Hellmund (1992) published a paper on Palaeochoerus and Propalaeochoerus which threw a great deal of light on the cranio-dental anatomy of these suoids, but like many authors before him (Dechaseaux, 1959; Ginsburg, 1974) and some after him (Sudre, 1995) he retained them in Tayassuidae. Van der Made $(1996,1997)$ articulated what had been in the air since Pickford's (1983) paper, that what were being called Old World Tayssuidae, should have a name of their own, the earliest available one for this group being Matthew's (1924) Palaeochoerinae, which Van der Made raised to family rank. But, in contrast to Matthew's concept, which included Miocene American peccaries along with Palaeochoerus in the subfamily, Van der Made excluded New World forms, and restricted it to Old World lineages. I consider this to be essentially correct. The family contains Propalaeochoerus Stehlin, 1899, Palaeochoerus Pomel, 1847, Lorancahyus Pickford \& Morales, 1998, Choeromorus Gervais, 1848 (which used to be called Taucanamo Simpson, 1945, and/or Choerotherium Lartet, 1851), Schizochoerus Crusafont-Pairo \& Lavocat, 1954, Morotochoerus Pickford, 1998, and Yunnanochoerus Van der Made \& Han, 1994 (if the latter is different from Schizochoerus). Doliochoerus Filhol, 1882, possibly belongs to the family, although its tympanic bullae are more inflated than in other genera which preserve evidence of this structure.

Palaeochoerids have no pentacone in the M3/, the P4/ is bicuspid, sometimes with a low disto-buccal cusplet, the I1/ has no distal cusplet, the upper canine jugum is inflated and forms a prominent projecting structure on the surface of the maxilla, the zygomatic process of the maxilla projects laterally, the palatines extend distally well beyond the level of the rear of the M3/, the glenoid surfaces are close to the rear of the skull and have a retro-glenoid process which faces antero-laterally, the sagittal crest is strong but antero-posteriorly short, the splanchnocranium is much longer than the neurocranium. In some taxa, such as Schizochoerus, the upper canine has a distal groove similar to that of Hippopotamus and the upper incisors are permanently growing. In the post-cranial skeleton, the distal epiphysis of the metapodials does not have a ridge, and the abaxial metapodials are long but slender. Whilst many of these characters are probably primitive at the level of 
Suoidea, some such as the ratio of splanchnocranium to neurocranium, clearly projecting canine jugum, and short sagittal crest are probably derived. The combination of characters differentiates the palaeochoerids from the other Suiformes which possess derived morphology for most of these features (Suidae, Anthracotheriidae, Tayassuidae, Sanitheriidae).

A similar combination of features (where preserved in the fossils) also occurs in Palaeopotamus and Kenyapotamus, which both share a number of derived characters with Hippopotamus and Choeropis such as the upper and lower canine morphology (Pickford, 2006) the upper incisor morphology, the trefoliate occlusal outline of the molar cusps and the shortened and broadened talus. Other features are inherited from their ancestral group, including the lack of pentacone on $\mathrm{M} 3 /$, the bicuspid $\mathrm{P} 4 /$ (sometimes with a low distal cusp) and the form of the distal talar trochlea for the navicular and cuboid among others. Finally it should be noted that derivation of hippopotamids from palaeochoerids does not require any reversion of characters, but does imply an increase in body size and some relatively modest changes in dental, cranial and post-cranial morphology.

\section{DISCUSSION}

Whatever the merits or otherwise of the supposed close relationship between hippopotamids and cetaceans based on molecular evidence, it is concluded that hippos are not particularly closely related to anthracotheres but are considerably closer to Palaeochoeridae. Theodor \& Foss (2006) and Geisler \& Uhen (2006) have independently come to the same conclusion that hippos are not closely related to anthracotheres. The former authors found evidence which lends support to the cebochoerid hypothesis of hippo origins on the basis of a study of the deciduous dentition of Eocene cebochoerids, supporting Pearson (1927). The latter authors reported that anthracotheres were more closely related to Suiformes than to hippos or whales.

On the basis of fossils from India, Thewissen et al. (2007) concluded that whales originated from aquatic artiodactyls in the Eocene. The presence of derived cetacean morphology in the raollid Indohyus, including the presence of an involucrum in the auditory bulla, can be interpreted in alternative ways. Thewissen et al. (2007) opted to retain Indohyus in the Artiodactyla, but they pointed out that it could be included in Cetacea. Whatever the case, this interpretation weakens the hypothesis that anthracotheres represent the group that links hippos to whales; not only because the Eocene age of Indohyus makes it as old or older than most anthracotheres, but also because anthracotheres possess auditory bullae with typically artiodactyl morphology (Pearson, 1929). Bothriodont anthracotheres, in particular, are therefore unlikely to represent the missing link between whales and hippos.
As Gatesy \& O’Leary (2001) pointed out, missing data, whether from missing skeletal elements of included taxa, or from missing taxa, can greatly affect the outcome of phylogenetic analyses. In my opinion, characters 10,58 and 61 of Boisserie et al. (2005a) could be scored for Palaeochoerus, yet were missing from their analysis and no postcranial evidence for Palaeochoerus was scored. A major problem with the character scoring of Palaeochoerus by Boisserie et al. (2005a) is that it was based on Pearson's (1927) analysis of a suid skull (Hyotherium) that was misattributed to Palaeochoerus (see Ginsburg, 1974; Van der Made, 1996). Cranial material attributed to Palaeochoerus typus Pomel, 1847, was described by Hellmund (1992) but only one specimen retains part of the basicranium, consisting of the glenoid region. Even though this skull was curated in the Natural History Museum, London, at the time of Pearson's (1927) study, apparently she did not examine it or if she did, then she could not find enough informative evidence in it to include in her study, because the basicranium and much of the otic region is missing.

So can incorrect scoring of characters radically change the outcome of phylogenetic analyses. In the case of $\mathrm{Pal}$ aeochoerus 8 characters $\left(\mathrm{N}^{\circ} \mathrm{s} 8,42,52,60,62,64,65\right.$ and 71) were incorrectly scored by Boisserie et al. (2005a) while most of the neurocranial and basicranial characters that they listed $\left(\mathrm{N}^{\circ}\right.$ s $\left.9,17,24,26,27,36,37,39,40\right)$ are suspect as they do not pertain to Palaeochoerus but to the suid Hyotherium, an error inherited from Pearson's (1927) initial misidentification of the fossils that she examined (Van der Made, 1996). Some of the latter characters may fortuitously be correct, but this cannot be demonstrated on the currently available fossils of Palaeochoerus. The mis-scoring of the proximal extension of the sinovial fossa in tali of Brachyodus also affects the outcome of the analysis.

A serious problem in defining character states is inherent in the wording used to describe morphology. For example, without additional information the words "elevated orbits" imply similar morphology, yet it is known than many unrelated animals possess orbits with the upper margin elevated above the dorsal profile of the skull, including gavialid crocodiles, phacochoerine suids, $\mathrm{Kva}$ bebihyrax Gabunia \& Vekua, 1966 (a late Miocene hyracoid from Georgia), Hippopotamus amphibius, and to a lesser extent Libycosaurus. Whilst elevated orbits in all these animals represent derived morphology within their respective groups, in none of them is the raised orbit homologous. Thus scoring "elevated orbits" in two unrelated animals in the same way in a phylogenetic analysis on the grounds that such a morphology is "derived" will lead to the invalid conclusion that the character is synapomorphic, as was done by Boisserie et al. (2005a, 2005b). Similarly, by scoring hypsorhyzic lower incisors (in hippos) and lower incisors with elongated roots (in Libycosaurus) in the same way, Boisserie et al. (2005a, 2005b) 
imposed synapomorphy on non-comparable morphology. Ditto the descending plate of the mandible in hippos and Merycopotamus. In essence, the problem is one of circularity of argument, similar terminology at the input stage of the analysis emerging as synapomorphies at the output stage, which is then taken to support the phylogeny.

Imperfections of the fossil record are significant in any phylogenetic analysis. In their studies Boisserie et al. (2005a, 2005b) not only omitted characters from included taxa, but they also omitted taxa, including most of the known genera of the family Palaeochoeridae. The fossil record of the latter family is poor when compared to the much better represented Anthracotheriidae, so poor indeed that it was only in 1983 that enough evidence was obtained to indicate that it required removal from Tayassuidae and warranted the creation of its own family, which was formally published in 1996. Even though its fossil record is poor, the fossils attributed to Palaeochoeridae share a number of morphological features with hippopotamids, including dental, cranial, and post-cranial ones. Improvement of their fossil record would be welcome, but even the limited amount of available evidence indicates that it is not necessary to invoke «spectacular reversion» of dental anatomy in order to explain the origin of hippopotamid dentitions, something which is necessary if the hippo ancestor were a bothriodont anthracothere. The few dental characters that were claimed to support the inferences of Boisserie et al. (2005a, 2005b) such as ever-growing canines and prolonged growth of the incisors in anthracotheres are incorrectly reported. Others such as wrinkled and pustular enamel in the premolars are not homologous in the two families. Instead, rather modest changes are all that are required to evolve the hippopotamid dentition from a palaeochoerid precursor.

Boisserie \& Lihoreau (2006) proposed some new scenarios of hippopotamid origins based on their 2005 analyses. These scenarios are compromised for the same reasons that their previous conclusions are.

\section{CONCLUSIONS}

Boisserie et al. (2005a, 2005b) did not refute the palaeochoerid hypothesis of hippo origins -they barely addressed it, as shown by the title of their first publication on the question, which was «Where do hippos come from: anthracotheres or peccaries?» (Lihoreau \& Boisserie, 2004) and the fact that only one palaeochoerid figures in their 2005 paper (Boisserie et al., 2005a). Subsequent publications do not differ fundamentally from this résumé of their initial research programme.

For a scientific hypothesis to be refuted it has to be tested. Needless to say, in a scientific milieu, any tests applied to a hypothesis need to be appropriate. Firstly, Boisserie et al. (2005a, 2005b) appear to have been una- ware of the separate familial status of the Palaeochoeridae, which therefore does not feature as such in their analysis. The family name has been formally applied to the group since 1996, even though the concept of a separate family has been in the literature since at least 1983, albeit under the somewhat confusing name «Old World Tayassuidae». Secondly, the characters included by Boisserie et al. (2005a, 2005b) for the genus Palaeochoerus, which is the type genus of the family Palaeochoeridae, came from skulls and jaws of the suid Hyotherium, which is why, in the phylogenetic tree (Boisserie et al., 2005a, Fig. 2) the genus falls close to Suidae and far from Tayassuidae. Thirdly, the only palaeochoerid in their analysis was Doliochoerus, for which only 62 out of 80 characters were scored (of which three were ambiguous). I disagree with the scoring of four of the dental characters. The postcranial skeleton of palaeochoerids was only represented by the talus (4 characters out of a possible seven) in one genus Doliochoerus.

Because of the absent taxa, missing morphological evidence for the taxa that were included in the analyses, questionable homologies and incorrectly reported morphology of some characters, the conclusions of Boisserie et al. (2005a, 2005b) are unsustainable. They do not represent a valid refutation of the hypothesis of a close relationship between palaeochoerids and hippopotamids. A counter hypothesis of sister-group relationship between anthracotheres and hippopotamids evoked by Boisserie $e t$ al. $(2005 \mathrm{a}, 2005 \mathrm{~b})$ is supported in part by incorrect observations of the morphology of anthracotheres (prolonged or ever-growing incisors and canines for example) but is in large measure due to convergent evolution, hippos and anthracotheres being potamophile and amphibious (cranial features such as elevated orbit and high external auditory meatus for example are due to convergence and are not synapomorphies) or to the retention of primitive morphology (some aspects of the morphology of the talus and metapodials, for instance).

In short, the palaeochoerid ancestry of hippopotamids is not a dead issue. It does not require «spectacular reversions» in dental anatomy (nor for that matter a wholesale reorganisation of morphology of the post-cranial skeleton) a major weakness of the contrasting hypothesis that anthracotheres represent the group from which hippos emerged. In brief, hippopotamids are airorhynch, have the splanchnocranium appreciably longer than the neurocranium, possess bunodont cheek teeth, have short necks, short carpal and tarsal complexes and shortened metapodials, whereas bothriodontine anthracotheres are klinorhynch, have the splanchnocranium about the same length as the neurocranium, possess selenodont cheek dentitions, have long necks, elongated carpal and tarsal complexes and elongated metapodials. These major differences in body plan are accompanied by many detailed differences in the morphology of virtually all the cranial and postcranial bones, 
and in growth variables such as of fusion of the mandibular symphysis and ankylosis of the radio-ulna. In all these features, hippos are closer to palaeochoerids than they are to anthracotheres.

The study of hippopotamid origins highlights the ambiguities that can arise during interpretion of morphological characters, some of which appear at face value to be synapomorphies linking two groups, but which turn out on closer inspection to be due to convergence. In the particular case of hippos and the anthracothere genus Merycopotamus, it is perhaps unprecedented that in the minds of so many researchers, only two superficially similar features (descended mandibular angle, and raised orbits) should have far outweighed in terms of phylogenetic signal, all the manifest differences that occur in the dentition, skull and post-cranial skeleton, thereby spuriously linking together two distinct groups which in reality separated from each other early during the Eocene, if not before. In fact these two supposed synapomorphies arose only during the late Miocene, once in hippos and independently once or perhaps twice in anthracotheres (Merycopotamus which possesses an upward notch in the mandibular base immediately anterior to the descending angle and Libycosaurus which does not). Apart from these two genera no other known anthracothere possesses a deeply descending mandibular angle, be it from the Eocene, Oligocene or Miocene, an observation already made by Lydekker in 1877 .

The complexity of the history of study of hippo-anthracothere relationships is due partly to imperfections of the fossil record, partly to divergence of opinions about the polarity of available morphological features and partly to sample choice and analytical methods used. But the complexity has been exacerbated by incorrect observations of morphology, misidentification of fossils and the tendency for errors to propagate through the literature for extended periods of time. All this history has been played out against the backdrop of a much broader question which has directly or indirectly influenced virtually all researchers, «Are the Artiodactyla monophyletic or paraphyletic ?». The uncertainty appears to be as flagrant today in the molecular age as it was during the decades that followed Darwin's publication on the origins of species. Although it is still not clear whether Artiodactyla are monophyletic or paraphyletic (Thewissen et al., 2007), a degree of consensus is emerging concerning the age of the hippopotamid-anthracothere divergence, with «early divergence» gaining ground over «late divergence» scenarios.

\section{ACKNOWLEDGEMENTS}

I am anxious to acknowledge support from the Collège de France, UMR 5143 of the CNRS, Département Histoire de la Terre du Muséum National d'Histoire Naturelle, the Service Géologique de Tunisie, and the Geological Survey of Namibia. Thanks to
Maeva Orliac for discussions about suiform anatomy and to Jerry Hooker and Andy Currant for access to material in the Natural History Museum, London, and Claire Sagne, for access to fossils in the Muséum National d'Histoire Naturelle, Paris.

\section{LITERATURE CITED}

Andrews, C.W. 1906. A Descriptive Catalogue of the Tertiary Vertebrata of the Fayûm, Egypt. British Museum of Natural History, London, 1-342.

Andrews, C.W. 1914. On the lower Miocene vertebrates from British East Africa, collected by Dr Felix Oswald. Quarterly Journal of the Geological Society of London, 70, 163-186.

Arambourg, C. 1961. Note preliminaire sur quelques vertébrés nouveaux du Burdigalien de Libye. Comptes Rendus Sommaires de la Société géologique de France, 4, 107-108.

Arnason, U., Gullberg, A., Gretasdottir, S., Ursing, B. \& Janke, A. 2000. The mitochondrial genome of the Sperm Whale and a new molecular reference for estimating eutherian divergence dates. Journal of Molecular Evolution, 50, 569-578.

Arnason, U., Gullberg, A. \& Janke, A. 2004. Mitogenic analyses provide new insights into cetacean origin and evolution. Gene, 333, 27-34.

Black, C. 1972. A new species of Merycopotamus (Artiodactyla: Anthracotheriidae) from the late Miocene of Tunisia. Notes du Service géologique de Tunisie, 37, Travaux de géologie Tunisienne, 6, 5-39.

Blainville, H. M. de 1847. Ostéographie et description iconographique des mammifères récents et fossiles. Baillères éditeur, Paris.

Boekschoten, G.J. \& Sondaar, P.Y. 1966. The Pleistocene of the Kathoro Basin (Crete) and its Hippopotamus. Bijdragen tot de Dierkunde, 36, 17-44.

Boekschoten, G.J. \& Sondaar, P.Y. 1972. On the fossil Mammalia of Cyprus I. Proceedings of the Koninklijke Nederlandse Akademie van Wetenschappen, 75, 306-338.

Boisserie, J.-R. 2005. The phylogeny and taxonomy of Hippopotamidae (Mammalia: Artiodactyla): a review based on morphology and cladistic analysis. Zoological Journal of the Linnean Society, 143, 1-26.

Boisserie, J.-R. \& Lihoreau, F. 2006. Emergence of Hippopotamidae: new scenarios. Comptes Rendus Palevol, 5, 749-756.

Boisserie, J.-R., Lihoreau, F. \& Brunet, M. 2005a. The position of Hippopotamidae within Cetartiodactyla. Proceedings of the National Academy of Science, 102, 1537-1541.

Boisserie, J.-R., Lihoreau, F. \& Brunet, M. 2005b. Origins of Hippopotamidae (Mammalia, Cetartiodactyla): towards resolution. Zoologica Scripta, 34, 119-143.

Bonarelli, G. 1947. Dinosauro fossile del Sahara Cirenaico. Rivista di Biologia Coloniale, Roma, 8, 23-33.

Bouvrain, G. \& De Bonis, L. 1999. Suoidea du Miocène inférieur de Laugnac (Lot-et-Garonne, France). Paläontologische Zeitschrift, 73, 167-178. 
Colbert, E.H. 1935. The phylogeny of the Indian Suidae and the origin of the Hippopotamidae. American Museum Novitates, 799, 1-24.

Cope, E.D. 1879. Second contribution to a knowledge of the Miocene fauna of Oregon. Proceedings of the American Philosophical Society, 18, 370-376.

Cope, E.D. 1882. Scientific news. American Naturalist, 16, 1029.

Cope, E.D. 1888. On the Dicotylinae of the John Day Miocene of North America. Proceedings of the American Philosophical Society, 25, 62-79.

Coryndon, S.C. 1976. Fossil Hippopotamidae from PlioPleistocene successions of the Rudolf Basin. In: Earliest Man and Environments in the Lake Rudolf Basin (Eds. Y. Coppens, F. Howell, G. Isaac \& R. Leakey). Chicago University Press, 238-250.

Coryndon, S.C. 1977. The taxonomy and nomenclature of the Hippopotamidae (Mammalia, Artiodactyla) and a description of two new fossil species. Proceedings of the Koninklijke Nederlandse Akademie van Wetenschappen, B.80 (2), 61-88.

Coryndon, S.C. 1978a. Hippopotamidae. In: Evolution of African Mammals (Eds. V.J. Maglio \& H.B.S. Cooke). Harvard University Press, Cambridge, 284-395.

Coryndon, S.C. 1978b. Fossil Hippopotamidae from the Baringo Basin and relationships within the Gregory Rift, Kenya. In: Geological Background to Fossil Man (Ed. W.W. Bishop). Scottish Academic Press, Edinburgh, 279-292.

Crusafont-Pairo, M. 1979. Les Giraffidés des gisements du Bled Douarah (W. de Gafsa) Tunisie. Notes du Service géologique de Tunisie, 44, 5-73.

Crusafont-Pairo, M., \& Lavocat, R. 1954. Schizochoerus un nuevo género de Suidos del Pontiense inferior (Vallesiense) del Valles Penedes. Notas y Communicaciones del Instituto Geologico y Minero de España, 36, 79-90.

Cuvier, G. 1804. Sur l'Hippopotame et sur son osteologie. Annales du Museum National d'Histoire Naturelle, Paris, 4, 299-328.

Cuvier, G. 1822. Recherches sur les ossements fossiles. $2^{\mathrm{ème}}$ Edition. E. d'Ocagne, Paris.

Dechaseaux, C. 1959. Le Genre Doliochoerus. Annales de Paléontologie, 54, 3-16.

Dehm, R. \& Oettingen-Spielberg, T. 1958. Paläontologische und geologische Untersuchungen im Tertiär von Pakistan. 2. Die mitteleocänen Säugetiere von Ganda Kas bei Basal in Nordwest-Pakistan. Bayerische Akademie der Wissenschaften, Abhandlungen, Klasse für Mathematik, Physik und Technik, 81, 1-54.

de Jong, W. 1998. Molecules remodel the mammalian tree. TREE, 13 (7), 271-275.

Depéret, C. 1895. Über die Fauna von miocänen Wirbelthieren aus der ersten Mediterranstufe von Eggenburg. Sitzsungsberichte der Mathematisch-Naturwissen schaftlichen Classe der kaiserlichen Akademie der Wissenschaften in Wien, 104, 1-22.

Depéret, C. 1921. La phylogenie des Hippopotames. Bulletin de la Société Géologique de France, $4^{\text {ème }}$ ser., 21, 163165 .
Dietrich, W.O. 1928. Pleistocäne deutschostafrikanische Hippopotamus-reste. Wissenschaften der Ergebnisse der Oldoway-Expedition, 1913, N.S. 3, 1-41.

Dineur, H. 1981. Le genre Brachyodus, Anthracotheriidae (Artiodactyla, Mammalia) du Miocène inférieur d'Europe et d'Afrique. Mémoires des Sciences de la Terre, Université Paris VI. Thèse 3ème Cycle, 1-180.

Falconer, H. 1868. Fauna Antiqua Sivalensis: Description of Plates. Smith, Elder \& Co, London.

Falconer, H. \& Cautley, P.T. 1836. Note on the fossil $\mathrm{Hi}$ ppopotamus of the Siwalik Hills. Asiatic Researches, 19, 39-53.

Falconer, H. \& Cautley, P.T. 1848. Fauna Antiqua Sivalensis, Plates. Smith, Elder \& Co, London.

Filhol, H. 1882. Observations relatives à un nouveau genre de Mammifères allié à la famille des Suidés. Comptes Rendus de l'Académie des Sciences de Paris, 1882, 1258.

Fischer von Waldheim, G., 1814. Zoognosia, Tabulis synopticis illustrata, Nikolai Sergedis Vsevolozky, Moscow, 3 volumes, 3-1814.

Forster-Cooper, C. 1915. New genera and species of mammals from the Miocene deposits of Baluchistan. Annals and Magazine of Natural History, 16, 404-409.

Forsyth Major, C. 1902. Some account of a nearly complete skeleton of Hippopotamus madagascariensis, Guldb., from Sirabé, Madagascar, obtained in 1895. Geological Magazine, 9, 192-199.

Fourtau, R. 1918. Contributions à l'étude des vertébrés miocènes de l'Egypte, Ministry of Finance Egypt Survey Department, i-vii+1-121.

Frechkop, S. 1955. Sous-ordre des Suiformes. In: Traité de Zoologie (Ed. P. Grassé). Masson et Cie, Paris, 17 (1), 509-535.

Gabunia, L., \& Vekua, A.K. 1966. An unusual member of the Hyracoidea from the upper Pliocene of Eastern Georgia. Akademii Nauk Gruzinskoy SSR Soobsch'eniya, 42 (3), 645-647.

Gatesy, J. 1997. More DNA support for a Cetacea/Hippopotamidae clade: the blood-clotting protein gene y-fibrinogen. Molecular Biology and Evolution, 14, 537-543.

Gatesy, J. 1998. Molecular evidence for the phylogenetic affinities of Cetacea. In: The Emergence of Whales (Ed. J.G.M. Thewissen). Plenum Press, New York, 63-111.

Gatesy, J., Hayashi, C., Cronin, M.A. \& Arctander, P. 1996. Evidence from milk casein genes that cetaceans are close relatives of hippopotamid artiodactyls. Molecular Biology and Evolution, 13, 954-963.

Gatesy, J., Milinkovitch, L., Waddell, V. \& Stanhope, M. 1999. Stability of cladistic relationships between Cetacea and higher-level artiodactyl taxa. Systematic Biology, 48, 6-20.

Gatesy, J. \& O'Leary, M. 2001. Deciphering whale origins with molecules and fossils. TREE, 16, 562-570.

Gaziry, A.W. 1982. Anthracotheriidae and Hippopotamidae from the Sahabi Formation. Garyounis Science Bulletin, Special Issue, 4, 63-70.

Gaziry, A.W. 1987a. Merycopotamus petrocchii (Artiodactyla, Mammalia) from Sahabi, Libya. In: Neogene Paleontology 
and Geology of Sahabi (Eds. N. Boaz et al.) Alan Liss, New York, 287-302.

Gaziry, A.W. 1987b. Hexaprotodon sahabiensis (Artiodactyla, Mammalia) a new Hippopotamus from Libya. In: Neogene Paleontology and Geology of Sahabi (Eds. N. Boaz et al.) Alan Liss, New York, 303-315.

Geais, G. 1934. Le Brachyodus borbonicus des Argiles de StHenri (près Marseille). Travaux du Laboratoire de Géologie du Faculté des Sciences, Lyon, 25 (Mém. 21), 3-54.

Geisler, J.H. 2001. New morphological evidence for the phylogeny of Artiodactyla, Cetacea and Mesonychidae. American Museum Novitates, 40, 1-53.

Geisler, J.H. \& Luo, Z. 1998. Relationships of Cetacea to terrestrial ungulates and the evolution of cranial vasculature in Cete. In: The Emergence of Whales (Ed. J.G.M. Thewissen). Plenum Press, New York, 163-212.

Geisler, J.H. \& O'Leary, M. 1997. A phylogeny of Cetacea, Artiodactyla, Perissodactyla, and archaic ungulates: the morphological evidence. Journal of Vertebrate Paleontology, 17, 48A.

Geisler, J.H. \& Uhen, M.D. 2003. Morphological support for a close relationship between hippos and whales. Journal of Vertebrate Paleontology, 23, 991-996.

Geisler, J.H. \& Uhen, M.D. 2006. Phylogenetic relationships of extinct cetartiodactyls: Results of simultaneous analyses of molecular, morphological, and stratigraphic data. Journal of Mammalian Evolution, 12, 145-160.

Gentry, A. \& Hooker, J. 1988. The phylogeny of the Artiodactyla. In: The Phylogeny and Classification of the Tetrapods Vol. 2 Mammals (Ed. M.J. Benton). Clarendon Press, Oxford, 235-272.

Gervais, P. 1848. Zoologie et Paléontologie françaises (animaux vertébrés) ou nouvelles recherches sur les animaux vivants et fossiles de la France. Paris, Bertrand, volume 1.

Gervais, P. 1852. Zoologie et Paléontologie françaises (animaux vertébrés) ou nouvelles recherches sur les animaux vivants et fossiles de la France. Paris, Bertrand, volume 3.

Gervais, P. 1859. Zoologie et Paléontologie françaises (animaux vertébrés). Nouvelles recherches sur les animaux vertébrés dont on trouve les ossements enfouis dans le sol de la France et sur leur comparaison avec les espèces propres aux autres régions du globe. Paris, Arthus Bertrand, 1 volume and 1 atlas.

Gingerich, P.D., Haq, M., Zalmout, I.S., Hussain, K.I. \& Malkani, M.S. 2001. Origin of whales from early artiodactyls: hands and feet of Eocene Protocetidae from Pakistan. Science, 293, 2239-2242.

Gingerich, P. \& Uhen, M. 1998. Likelihood estimation of the time of origin of Cetacea and the time of divergence of Cetacea and Artiodactyla. Palaeontologica electronica, 1, 1-47.

Ginsburg, L. 1974. Les Tayassuidés des Phosphorites du Quercy. Palaeovertebrata, 6, 55-85.

Ginsburg, L. 1980. Xenohyus venitor, suidé nouveau (Mammalia, Artiodactyla) du Miocène inférieur de France. Geobios, 13, 861-877.
Ginsburg, L., Huin, J. \& Locher, J.-P. 1988. Les Suidae (Artiodactyla, Mammalia) du Miocène inférieur des Beilleaux à Savigné-sur-Lathal (Indre-et-Loire). Bulletin du Muséum National d'Histoire Naturelle, 20, 197-207.

Grauer, D. \& Higgins, D.G. 1994. Molecular evidence for the inclusion of cetaceans within the order Artiodactyla. Molecular Biology and Evolution, 11, 357-364.

Gray, J.E. 1850. Preface. In: Gleanings from the Menagerie and Aviary at Knowsley Hall, Volume 2, Hoofed Quadrupeds, Knowsley, Printed for Private Distribution, p. 23.

Gray, J.E. 1854. On the painted pig of the Cameroons (Potamochoerus penicillatus). Proceedings of the Zoological Society of London, 1852, 129-131.

Gray, J.E. 1868. Synopsis of the species of pigs (Suidae) in the British Museum. Proceedings of the Zoological Society of London, 1868, 17-49.

Guldberg, G.A. 1883. Undersøgelser over en subfossil Flodhest fra Madagaskar. Forhandlinger $i$ Videnskabsselskabet i Kristiana, 6, 1-24.

Harris, J.M. 1991. Family Hippopotamidae. In: Koobi Fora Research Project 3. The Fossil Ungulates: Geology, Fossil Artiodactyls and Palaeoenvironments (Ed. J.M. Harris). Clarendon Press, Oxford, 31-85.

Harrison, T. 1997. The anatomy, paleobiology, and the phylogenetic relationships of the Hippopotamidae (Mammalia, Artiodactyla) from the Manonga Valley, Tanzania. In: Neogene Paleontology of the Manonga Valley, Tanzania (Ed. T. Harrison). Topics in Geobiology, 14, New York, Plenum Press, 137-190,

Hasegawa, M. \& Adachi, J. 1996. Phylogenetic position of cetaceans relative to artiodactyls: Reanalysis of mitochondrial and nuclear sequences. Molecular Biology and Evolution, 13, 710-717.

Hasegawa, M., Adachi, J. \& Milinkovitch, M.C. 1997. Novel phylogeny of whales supported by total molecular evidence. Journal of Molecular Evolution, 44 (Suppl. 1), S117-S120.

Hellmund, M. 1992. Schweinartige (Suina, Artiodactyla, Mammalia) aus oligo-miozänen Fundstellen Deutschlands, der Schweiz und Frankreichs II. Revision von Palaeochoerus Pomel, 1847 und Propalaeochoerus Stehlin 1899 (Tayassuidae). Stuttgarter Beiträge zur Naturkunde, Serie $B$ (Geologie und Paläontologie), 189, 1-75.

Hodgson, B.H. 1847. On various genera of the ruminants. Journal of the Asiatic Society of Bengal, 16, 685-711.

Houtekamer, J.L. \& Sondaar, P.Y. 1979. Osteology of the forelimb of the Pleistocene Dwarf Hippopotamus from Cyprus with special reference to phylogeny and function. Proceedings of the Koninklijke Nederlandse Akademie van Wetenschappen, B.82, 411-448.

Huxley, T. 1871. Anatomy of Vertebrated Animals, Churchill, London, $431 \mathrm{pp}$.

Illiger, J.K.W. 1815. Überblick der Säugethiere nach ihrer Vertheilung über die Welttheile. Abhandlungen der Physikalischen Klasse der Königlich-Preussischen Akademie der Wissenschaften aus den Jahren 1804-1811, 39-159.

Joleaud, L. 1920. Contribution à l'étude des Hippopotames fossiles. Bulletin de la Société Géologique de France, $4^{\text {ème }}$ ser., 20, 13-26. 
Kerr, R., 1792. Animal Kingdom or Zoological System of the Celebrated Sir Charles Linnaeus; Class I. Mammalia ... London, J. Murray \& R. Faulder, Volume 1, 400 pp.

Kleineidam, R., Pesole, G., Breukelman, H., Beintema, J. \& Kasrelein, R. 1999. Inclusion of cetaceans within the Order Artiodactyla based on phylogenetic analyses of pancreatic ribonuclease genes. Journal of Molecular Evolution, 48, 360-368.

Kowalevsky, W. 1873. On the osteology of the Hyopotamidae. Philosophical Transactions of the Royal Society of London, 39, 1-94.

Kowalevsky, W. 1874. Monographie der Gattung Anthracotherium Cuv. und Versuch einer natürlich Classification der fossilen Hufthiere. Palaeontographica, 22, 133-346.

Langer, P. 2001. Evidence from the digestive tract on phylogenetic relationships in ungulates and whales. Journal of Zoological Systematics and Evolutionary Research, 39, 77-90.

Lartet, E. 1851. Notice sur la colline de Sansan, suivi d'une récapitulation des diverses espèces d'animaux vertébrés fossiles, trouvés, soit à Sansan, soit dans d'autres gisements de terrain Tertiaire miocènes dans le bassin souspyrénéen, Auch.

Lavocat, R. 1955. Sous-ordre des Suiformes. In: Traité de Zoologie (Ed. P. Grassé). Masson et Cie, Paris, 17 (1), 536-551.

Laws, R.M. 1968. Dentition and ageing of the Hippopotamus. East African Wildlife Journal, 6, 19-52.

Leakey, L.S.B. 1966. Tertiary fossil mammals (discussion). In: African Ecology and Human Evolution (Eds. F.C. Howell \& F. Bourlière). Aldine, Chicago, 553-554.

Leidy, J. 1850. Observations on two new genera of fossil Mammalia, Eucrotophus jacksoni, and Archaeotherium mortoni. Proceedings of the National Academy of Sciences of Philadelphia, 5, 90-93.

Leidy, J. 1853. A memoir on the extinct Dicotylinae of America. Transactions of the American Philosophical Society, 10, 323-343.

Leidy, J. 1869. The extinct mammalian fauna of Dakota and Nebraska, including an account of some allied forms from other localities, together with a synopsis of the mammalian remains of North America. Journal of the Academy of Natural Science of Philadelphia, 2, 1-427.

Lihoreau, F. 2003. Systématique et Paléoécologie des Anthracotheriidae (Artiodactyla: Suiformes) du Mio-Pliocène de l'Ancien Monde: implications Paléobiogéographiques. Thèse, University of Poitiers, 395 pp.

Lihoreau, F. \& Boisserie, J.-R. 2004. Where do hippos come from: anthracotheres or peccaries? Journal of Vertebrate Paleontology, 24 (supplement), 83A.

Link, H.F. 1795. Über die Lebenskrafte in naturhistorischer Rücksicht und die Classification der Saugethiere, Beytrage zur Naturgeschichte, Rostock, 2, 104.

Linnaeus, C. 1758. Systema Natura, $10^{\text {th }}$ Edition.

Luckett, P. \& Hong, N. 1998. Phylogenetic relationships between the orders Artiodactyla and Cetacea: a combined assessment of morphological and molecular evidence. Journal of Mammalian Evolution, 5, 127-182.
Lydekker, R. 1876. Notes on the osteology of Merycopotamus dissimilis. Records of the Geological Survey of India, 9, 144-153.

Lydekker, R. 1877. Notices of new and rare mammals from the Siwaliks. Records of the Geological Survey of India, 10, 76-83.

Lydekker, R. 1883. Indian Tertiary and Post-Tertiary Vertebrata: Siwalik Selenodont Suina. Palaeontologica indica, 10, 143-177.

Lydekker, R., 1885. Catalogue of the Fossil Mammalia in the British Museum, Part 2. Taylor \& Francis, London, 323 pp.

Lydekker, R. 1886. Indian Tertiary and Post-Tertiary Vertebrata: Siwalik Mammalia - Supplement 1. Palaeontologica indica, 4, 16-18, Pl. 5, 6.

MacInnes, D.G. 1951. Miocene Anthracotheriidae from East Africa. Fossil Mammals of Africa, 4, 1-24.

Marsh, O.C. 1875. Notice of new Tertiary mammals, IV. American Journal of Science, 3, 239-250.

Matthew, W.D. 1907. A lower Miocene fauna from South Dakota. Bulletin of the American Museum of Natural History, 23, 169-219.

Matthew, W.D. 1924. Third contribution to the Snake Creek fauna. Bulletin of the American Museum of Natural History, 50, 59-210.

Matthew, W.D. 1929a. Reclassification of the artiodactyl families. Bulletin of the Geological Society of America, 40, 403-408.

Matthew, W.D. 1929b. Critical observations upon Siwalik Mammals. Bulletin of the American Museum of Natural History, 56, 437-560.

Matthew, W.D. 1934. A phylogenetic chart of the Artiodactyla. Journal of Mammalogy, 15, 207-209.

Meisner, A., Klaus, A. \& O’Leary, M. 2005. Sperm head morphology in 36 species of Artiodactylans, Perissodactylans and Cetaceans (Mammalia). Journal of Morphology, 263, 179-202.

Milinkovitch, M.C., Bérubé, C. \& Palsboll, P. 1998. Cetaceans are highly derived artiodactyls. In: The Emergence of Whales (Ed. J.G.M. Thewissen). Plenum Press, New York, 113-131.

Milinkovitch, M.C. \& Thewissen, J.G.M. 1997. Even-toed fingerprints on whale ancestry. Nature, 388, 622-624.

Miyamoto, M. 1999. Molecular systematics: Perfect SINEs of evolutionary history? Current Biology, 9, 816-819.

Montgelard, C., Catzeflis, F.M. \& Douzery, E. 1997a. Phylogenetic relationships of artiodactyls and cetaceans as deduced from the comparison of cytochrome $\mathrm{b}$ and $12 \mathrm{~s}$ rRNA mitochondrial sequences. Molecular Biology and Evolution, 14, 550-559.

Montgelard, C., Ducrocq, S. \& Douzery, E. 1997b. What is a suiforme (Artiodactyla)? Contribution of cranioskeletal and mitochondrial DNA data. Molecular Phylogenetics and Evolution, 9, 528-532.

Morton, S.G. 1849. Additional observations on a new living species of hippopotamus. Journal of the National Academy of Sciences of Philadelphia, 1 (4), 231-239.

Nakaya, H., Pickford, M., Yasui, K. \& Nakano, Y. 1987. Additional large mammalian fauna from the Namurungule 
Formation, Samburu Hills, Northern Kenya. African Study Monographs, Supplementary Issue, 5, 79-130.

Naylor, G. \& Adams, D.C. 2001. Are the fossil data really at odds with the molecular data? Morphological evidence for Cetartiodactyla phylogeny reexamined. Systematic Biology, 50, 444-453.

Naylor, G. \& Adams, D.C. 2003. Total evidence versus relevant evidence: a response O'Leary et al. (2003). Systematic Biology, 52, 864-865.

Nikaido, M., Rooney, A.P. \& Okada, N. 1999. Phylogenetic relationships among cetartiodactyls based on insertions of short and long interspersed elements: hippopotamuses are the closest extant relatives of whales. Proceedings of the National Academy of Sciences of the United States of America, 96, 10261-10266.

Nomura, O. \& Yasue, H. 1999. Phylogenetic relationships among hippopotamus, whales, and bovine based on SINE insertion analysis. Mammalian Genome, 10, 526-527.

Nomura, O., Lin, Z-H., Muladno, Wada, Y. \& Yasue, H. 1998. A SINE species from Hippopotamus and its distribution among animal species. Mammalian Genome, 9, 550-555.

Ogilby, W. 1840. Proceedings of the Zoological Society of London, 8 (88 \& 89), 35.

O'Leary, M. 1998. Phylogenetic and morphometric reassessment of the dental evidence for a mesonychian and cetacean clade. In: The Emergence of Whales (Ed. J.G.M. Thewissen). Plenum Press, New York, 133-161.

O'Leary, M. 1999. Parsimony analysis of total evidence from extinct and extant taxa and the cetacean - artiodactyl question (Mammalia, Ungulata). Cladistics, 15, 315-330.

O'Leary, M. 2001. The phylogenetic position of cetaceans: further combined data analyses, comparisons with the stratigraphic record and a discussion of character optimization. American Zoologist, 41, 487-506.

O’Leary, M. \& Geisler, J.H. 1999. The position of Cetacea within Mammalia: phylogenetic analysis of morphological data from extinct and extant taxa. Systematic Biology, 48, 455-490.

O'Leary, M., Geisler, J.H. \& Novacek, M. 2003. Are the dental data really at odds with the molecular data? Morphological evidence for Whale phylogeny $(\mathrm{Re})$ Reexamined. Systematic Biology, 52, 853-864.

O'Leary, M. \& Uhen, M.D. 1999. The time of origin of whales and the role of behavioral changes in the terrestrialaquatic transition. Paleobiology, 25, 534-556.

Owen, R. 1845. Odontography. London, H. Bailliere, 655 pp.

Palmer, T.S. 1897. Notes on the nomenclature of four genera of tropical American mammals. Proceedings of the Biological Society of Washington, 11, 173-174.

Pearson, H.S. 1927. On the skulls of early Tertiary Suidae together with an account of the otic region in some other primitive Artiodactyla. Philosophical Transactions of the Royal Society of London, B215, 389-460.

Pearson, H.S. 1929. The hinder end of the skull in Merycopotamus and in Hippopotamus minutus. Journal of Anatomy, 63, 237-241.
Pickford, M. 1983. On the origins of the Hippopotamidae together with a description of two new species, a new genus and a new subfamily from the Miocene of Kenya. Geobios, 16, 193-217.

Pickford, M. 1989. Update on hippo origins. Comptes Rendus de l'Académie des Sciences, Paris, 309, 163-168.

Pickford, M. 1990. The discovery of Kenyapotamus in Tunisia. Annales de Paléontologie, 76, 277-283.

Pickford, M. 1991. Revision of the Neogene Anthracotheriidae of Africa. In: The Geology of Libya (Ed. M.J. Salem). Elsevier, Amsterdam, 4, 1491-1525.

Pickford, M. 1993. Old World Suoid systematics, phylogeny, biogeography and biostratigraphy. Paleontologia i Evolucio, 26-27, 237-269.

Pickford, M. 1998. A new genus of Tayassuidae (Mammalia) from the middle Miocene of Uganda and Kenya. Annales de Paléontologie, 84, 275-285.

Pickford, M. 2001. Afrochoerodon nov. gen. kisumuensis (MacInnes) (Proboscidea, Mammalia) from Cheparawa, Middle Miocene, Kenya. Annales de Paléontologie, 87, 99-117.

Pickford, M. 2003. Early and Middle Miocene Anthracotheriidae (Mammalia, Artiodactyla) from the Sperrgebiet, Namibia. Memoirs of the Geological Survey of Namibia, 19, 283-290.

Pickford, M. 2006. Sexual and individual morphometric variation in Libycosaurus (Mammalia, Anthracotheriidae) from the Maghreb and Libya. Geobios, 39, 267-310.

Pickford, M. 2007. Suidae and Hippopotamidae from the Middle Miocene of Kipsaraman, Kenya, and other sites in East Africa. Paleontological Research, 11, 85-105.

Pickford, M., 2008. Libycosaurus petrocchii Bonarelli, 1947, and Libycosaurus anisae (Black, 1972) (Anthracotheriidae, Mammalia): nomenclatural and geochronological implications. Annales de Paléontologie, 94, 39-55.

Pickford, M. (in press). The anterior dentition of Libycosaurus anisae and Kenyapotamus coryndoni from Beglia, Tunisia: implications for the affinities of anthracotheres and hippopotamids. Notes du Service Géologique de Tunisie (in press).

Pickford, M. \& Morales, J. 1989. On the tayassuid affinities of Xenohyus, Ginsburg, 1980, and the description of new fossils from Spain. Estudios Geológicos, 45, 233-237.

Pickford, M., \& Morales, J. 1998. A tubulidentate suiform lineage (Tayassuidae, Mammalia) from the early Miocene of Spain. Comptes Rendus de l'Académie des Sciences de Paris, 327, 285-290.

Pilgrim, G.E. 1925. Presidential address to the geological section of the 12th Indian Science Congress. Proceedings of the 12th Indian Science Congress, 200-218.

Pomel, A. 1847. Note sur des animaux fossiles découvertes dans le département de l'Allier. Bulletin de la Société Géologique de France, $2^{\text {ème }}$ ser., 4, 378-385.

Randi, E., Lucchini, V. \& Cheong Hoong Diong, 1996. Evolutionary genetics of the Suiformes as reconstructed using mtDNA sequencing. Journal of Mammalian Evolution, 3, 163-194.

Shimamura, M., Yasue, H., Ohshima, K., Abe, H., Kato, H., Kishiro, T., Goto, M., Munechika, I. \& Okada, N. 1997. 
Molecular evidence from retroposons that whales form a clade within even-toed ungulates. Nature, 388, 666-670.

Shimamura, M., Abe, H., Nikaido, M., Ohshima, K. \& Okada, N. 1999. Genealogy of families of SINEs in cetaceans and artiodactyls: the presence of a huge superfamily of

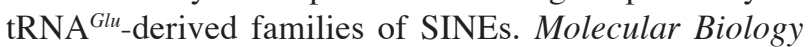
and Evolution, 16, 1046-1060.

Simpson, G.G. 1945. The principals of classification and a classification of mammals. Bulletin of the American Museum of Natural History, 85, 1-350.

Sisson, S. \& Grossman, J. 1953. The Anatomy of the Domestic Animals, 4th Edition, W.B. Saunders, Philadelphia and London, 972 pp.

Shedlock, A., Milinkovitch, M. \& Okada, N. 2000. SINE evolution, missing data, and the origins of whales. Systematic Biology, 49, 808-817.

Spaan, A. 1996. Hippopotamus creutzbergi; the case of the Cretan hippopotamus. In: Pleistocene and Holocene fauna of Crete and its first settlers (Ed. D.S. Reece). Monographs in World Archaeology, Prehistory Press, 28, 99-110.

Speke, J.H. 1863. Journal of the Discovery of the Source of the Nile. J. M. Dent and Sons, Limited (No. 50 of the Everyman's Library) p. 223.

Stehlin, H.G. 1899-1900. Über die Geschichte des SuidenGebisses. Abhandlungen der Schweizerische Paläontologische Gesellschaften, 26-27, 1-527.

Stehlin, H.G. 1908. Die Säugetiere des Schweizerischen Eocäns. 5 teil (Suidae). Abhandlungen der Schweizerische Paläontologische Gesellschaften, 35, 1-696.

Sudre, J. 1995. La Garouillas et les sites contemporains (Oligocène, MP 25) des phosphorites du Quercy (Lot, Tarn-et-Garonne, France) et leurs faunes de vertébrés. Palaeontographica Abteilung A, 236, 205-256.

Swinhoe, R. 1870. On a new deer from China. Proceedings of the Zoological Society of London, 1870, 88-92.

Thenius, E. 1969. Phylogenie der Mammalia, Stammesgeschichte der Säugetiere. Berlin, Walter de Gruyter and Co.

Theodor, J.M. \& Foss, S.E. 2006. Deciduous dentitions of Eocene Cebochoerid artiodactyls and cetartiodactyl relationships. Journal of Mammalian Evolution, 12,161181.

Thewissen, J.G.M., Russel, D., Gingerich, P. \& Hussain, S.T. 1983. A new dichobunid artiodactyl (Mammalia) from the Eocene of north-west Pakistan. Dentition and Classsification. Proceedings of the Koninklijke Nederlandse Akademie van Wetenschappen, 86, 153-180.

Thewissen, J.G.M., Madar, S.I. \& Hussain, S.T. 1998. Whale ankles and evolutionary relationships. Nature, 395, 452.

Thewissen, J.G.M., Williams, E.M., Roe, L.J. \& Hussain, S.T. 2001. Skeletons of terrestrial cetaceans and the relationship of whales to artiodactyls. Nature, 413, 277-281.

Thewissen, J.G.M., Cooper, L.N., Clementz, M.T., Bajpai, S. \& Tiwari, B.N. 2007. Whales originated from aquatic artiodactyls in the Eocene epoch in India. Nature, 450, 1190-1194.
Trouessart, E. 1904. Catalogus mammalium, Quinquennale I Supplementum.

Tsubamoto, T., Takai, M., Egi, N., Nobuo, S., Soe, T.T., Aye, K.A., Aung, N.S. \& Tin, T. 2002. The Anthracotheriidae (Mammalia; Artiodactyla) from the Eocene Pondaung Formation (Myanmar) and comments on some other anthracotheres from the Eocene of Asia. Palaeontological Research, 6, 363-384.

Tsujikawa, H. 2005. The updated Late Miocene large mammal fauna from Samburu Hills, northern Kenya. African Study Monographs, Supplement, 32, 1-50.

Ursing, B.M. \& Arnason, U. 1998. Analyses of mitochondrial genomes strongly support a hippopotamus-whale clade. Proceedings of the Royal Society of London, B265, 2251-2255.

Ursing, B.M., Slack, K. \& Arnason, U. 2000. Subordinal artiodactyl relationships in the light of phylogenetic analysis of 12 mitochondrial protein-coding genes. Zoologica Scripta, 29, 83-88.

Weston, E.M. 2003. Fossil Hippopotamidae from Lothagam. In: Lothagam: The Dawn of Humanity in Eastern Africa (Eds. M.G. Leakey \& J.M. Harris). Columbia University Press, New York, 441-483.

Van der Made, J. 1996. Albanohyus, a small Miocene pig. Acta zoologica cracoviana, 39, 293-303.

Van der Made, J. 1997. Systematics and stratigraphy of the genera Taucanamo and Schizochoerus and a classification of the Palaeochoeridae (Suoidea, Mammalia). Proceedings of the Koninklijke Nederlandse Akademie van Wetenschappen, 100, 127-139.

Van der Made, J. 1999. Superfamily Hippopotamoidea. In: Miocene Land Mammals of Europe (Eds. G.E. Rössner \& K. Heissig). Pfeil Verlag, München, 203-208.

Van der Made, J., \& Han Defen, 1994. The Suiodea from the hominoid locality Lufeng (Yunnan, China). Proceedings of the Koninklijke Nederlandse Akademie van Wetenschappen, 97, 27-82.

Viret, J. 1961. Artiodactyla. In: Traité de Paléontologie, (Ed. J. Piveteau) Masson et Cie, Paris, 6 (1), 887-1021, 1038-1084.

Von Meyer, H. 1834. Die fossilen Zähne und knocken und ihre Ablagerung in der Gegend von Georgensmund in Bayern. Museum Senckenbergianum, 1, Supplement 4, i-viii, 1-126.

Xu, X., Janke, A. \& Arnason, U. 1996. The complete mitochondrial DNA sequence of the greater Indian Rhinoceros unicornis, and the phylogenetic relationship among Carnivora, Perissodactyla, and Artiodactyla (+ Cetacea). Molecular Biology and Evolution, 13, 1167-1173.

Zbyszewski, G. 1949. Les vertébrés du Burdigalien supérieur de Lisbonne, Service Géologique du Portugal, Lisbon, 1949, 1-77.

Manuscrito recibido: 28 de Septiembre, 2007 Manuscrito aceptado: 22 de Febrero, 2008 


\title{
PALEOCLIMA Y PAISAJE DEL FINAL DEL CUATERNARIO EN CANTABRIA: LOS PEQUEÑOS MAMÍFEROS DE LA CUEVA DEL MIRÓN (RAMALES DE LA VICTORIA)
}

\author{
Gloria CUENCA-BESCÓS ${ }^{1-2}$, Lawrence G. \\ STRAUS $S^{2-3}$, Manuel R. GONZÁLEZ MORALES $S^{3} y$ \\ Juan C. GARCÍA PIMIENTA ${ }^{1}$ \\ ${ }^{1}$ Area de Paleontología, Departamento de Ciencias de la Tierra, Universidad \\ de Zaragoza, 50009 Zaragoza, España \\ ${ }^{2}$ Department of Anthropology, MSCO1-1040, University of New Mexico, Al- \\ buquerque, NM 87131-0001, USA \\ ${ }^{3}$ Instituto Internacional de Investigaciones Prehistóricas, Universidad de Can- \\ tabria, Avda. de los Castros, 39005 Santander, España
}

Cuenca-Bescós, G., Strauss, L. G., González Morales, M. R. \& García Pimienta, J. C. 2008. Paleoclima y paisaje del final del cuaternario en Cantabria: Los Pequeños mamíferos de la cueva del Mirón (Ramales de la Victoria). [Paleoclimate and landscape at the late quaternary in cantabria: the small mammals from El Mirón cave (Ramales de la Victoria).] Revista Española de Paleontología, 23 (1), 91-126. ISSN 0213-6937.

\begin{abstract}
The great diversity of small mammals in the Upper Pleistocene and Holocene deposits of El Mirón Cave, with a total of 26 species belonging to 6 mammalian orders (Erinaceomorpha, Soricomorpha, Chiroptera, Carnivora, Rodentia and Lagomorpha), makes this an important sequence for the study of the development of small mammal associations during the Pleistocene-Holocene transition; what it allows us to know the evolution of the climate and the landscape in the Cantabrian Region. At the end of the Quaternary, the last extinction of Pleistocene microfauna is registered, like the one of the vole Pliomys lenki, related to present day Dinaromys, the Balkan Snow (or Martino's vole). Also local extinction are documented like the disappearance from Spain of cold-climate mammals characteristic of the steppe-tundra ecozones of Northern Europe and Siberia namely Microtus oeconomus and M. gregalis. The extinctions can be explained by the climatic changes that occurred at the end of the Quaternary, without discarding the competition with species inmigrants, of similar ecology. Late in the Holocene, human activity -especially deforestation and cereal agriculture- is reflected at El Mirón in a decline in species diversity among the small mammals.
\end{abstract}

Key Words: El Mirón cave, Biostratigraphy, Paleoclimate, small mammals, Quaternary, Cantabrian Region, Spain.

\section{RESUMEN}

La gran diversidad en pequeños mamíferos del Pleistoceno superior y Holoceno de la Cueva del Mirón, con un total de 26 especies pertenecientes a seis órdenes de mamíferos (Erinaceomorpha, Soricomorpha, Chiroptera, Carnivora, Rodentia y Lagomorpha) hace de la secuencia del Mirón un importante documento sobre la distribución de las asociaciones de pequeños mamíferos durante la transición Pleistoceno-Holoceno; lo que nos permite conocer la evolución del clima y del paisaje en la Región Cantábrica. Al final del Cuaternario se registra la última extinción de microfauna Pleistocena, como la del topillo Pliomys lenki, relacionado con el actual Dinaromys, el topillo nival de los Balcanes o de Martino. También se documentan extinciones locales, como la desaparición del territorio español de los mamíferos característicos de las estepas del Norte de Europa y Siberia, como Microtus oeconomus y M. gregalis. Estas extinciones se pueden explicar por los cambios climáticos ocurridos al final del Cuaternario, sin descartar la competencia con especies inmigrantes, de ecología similar. El final del Holoceno, la actividad humana, sobre todo la deforestación y la cultura cerealística, se refleja también en la disminución de la diversidad específica de los pequeños mamíferos.

Palabras clave: Cueva del Mirón, Bioestratigrafía, Paleoclima, pequeños mamíferos, Cuaternario, Cornisa Cantábrica, España. 


\section{LOS PEQUEÑOS MAMÍFEROS DEL PLEISTOCENO SUPERIOR Y HOLOCENO DE ESPAÑA}

El estudio sistemático de las faunas de pequeños mamíferos de yacimientos arqueo-paleontológicos del Pleistoceno superior español comenzó con los trabajos de Altuna $(1970,1972,1981,1986)$ seguidos en la década de los 80 y hasta mediados de los 90 por los trabajos de Alcalde Gurt (1982), Alcalde \& Brunet (1985), Gil \& Sesé (1985), Pemán $(1985,1987,1988,1990 a, b)$, Alcalde $(1986,1988)$, Agustí et al. (1987), Gil \& Lanchares (1988), Álvarez et al. (1992), Guillem (1995a, b, 1999), y ya en la última década, son algo más numerosos los trabajos sobre pequeños mamíferos con el objeto de reconstruir la evolución de los ecosistemas terrestres del Pleistoceno superior y los cambios ambientales de esta reciente etapa de la historia terrestre (Pokines, 1998, 2000; Guillén, 2001; Sesé, 2005; López-García, 2006; Zubeldia Garmendia, 2006; LópezGarcía \& Morales Hidalgo, 2007). Sin embargo, los estudios sobre los pequeños mamíferos son escasos en los yacimientos arqueológicos de edad Holocena y ni siquiera son mencionados como componentes de los niveles excavados, ya que pasan desapercibidos. Como una excepción podemos mencionar los trabajos de Morales Muñíz (1986), Pemán (1987, 1988, 1990 a, b), Laplana Conesa \& Cuenca-Bescós (1995), Morales Muñiz et al. (1997), Morales \& Rodríguez (1997), Riquelme Cantal \& Morales Muñiz (1997) y Altuna et al. (2004).

En general los pequeños mamíferos del Pleistoceno español han sido analizados por su interés en bioestratigrafía (Cuenca-Bescós et al., 1995, 1997, 1999; Oms et al., 2000; Ruiz Bustos, 2004). Recientemente, el refinamiento e incremento de técnicas de datación radiométrica, hace que los pequeños mamíferos sean útiles además por su valor como indicadores paleoecológicos y paleoclimáticos (Sesé \& Sevilla, 1996; López Antoñanzas \& Cuenca-Bescós, 2002; Cuenca-Bescós et al., 2005; Sesé, 2005).

Los pequeños mamíferos son parte elemental de los ecosistemas terrestres: forman parte de la dieta de numerosos predadores como mamíferos carnívoros (hurones, martas, comadrejas, zorros, lobos), aves de presa (búhos, lechuzas, mochuelos, ratoneros, halcones) e incluso de otros pequeños animales no especializados en la caza de vertebrados como el lirón careto, ratas, córvidos, alcaudones (Chaline, 1972; Ruiz \& Camacho, 1973; Nores, 1979; Moreno \& Rey, 1980; Arrizabalaga i Blanch et al., 1986; Hernández et al., 1987; Andrews, 1990; Vargas \& Palomo, 1990; Gosálbez, 1993; Eastham, 1995; Pokines, 1998; Frafjord, 2003; Carvalho \& Gomes, 2004; Hernández, 2005; observaciones personales). Los pequeños mamíferos son los herbívoros (roedores y lagomorfos) y predadores (insectívoros, murciélagos, pequeños carnívoros) más pequeños en la cadena trófica de los vertebrados. Su pequeño tamaño los excluye como componentes de la dieta huma- na (al menos durante el Pleistoceno superior y Holoceno inicial) por lo que su presencia en los yacimientos se debe a los factores ya mencionados de acumulación, como el de la predación. Hay que resaltar que, aunque los casos de comensalismo son raros durante el Pleistoceno y gran parte del Holoceno, Pokines (1998) propone una posible relación entre la presencia del erizo (Erinaceus Linnaeus, 1758), o la de los lirones (gris: Myoxus Brisson, 1762, y careto: Eliomys Wagner, 1840) y las ocupaciones humanas. Así mismo, Eastham (1995) plantea el aprovechamiento de la piel del topo común europeo (Talpa europaea Linnaeus, 1758) por parte de los humanos; para explicar la notable cantidad de restos de este pequeño mamífero en los niveles Magdalenienses de Dufaure (acantilados de Pastou, con el notable conjunto de yacimientos Magdalenienses de Dufaure, Duruthy Les Pastous) en Les Landes, Gascogne, no lejos de la frontera Franco-Española. Al final del Holoceno y sobre todo en la actualidad, se conoce bien la estrecha relación de comensalismo con los humanos, de los ratones y las ratas (Mus Linnaeus, 1758, y Rattus Fischer, 1803; ver Morales \& Rodríguez, 1997). Por otra parte hay especies que se propagan con la expansión del cultivo de cereales o árboles frutales como el ratón espiguero, Micromys minutus (Pallas, 1771) (Morales Muñiz \& Rodríguez, 1997; Palomo \& Gisbert, 2002; Nores, 2003).

Es interesante resaltar que el cultivo o el uso de cereales en el Neolítico del Mirón (Peña-Chocarro et al., 2005) no parece haber influido en la entrada de estas faunas comensales en la Cornisa Cantábrica, ya que lo hacen mucho más tarde, al final del Holoceno; sin haberse encontrado hasta ahora en los niveles estudiados del Mirón. La mayor parte de los restos de pequeños mamíferos acumulados en cuevas como la del Mirón son el resultado de la actividad biológica de las aves de presa, con algún aporte ocasional por parte de mamíferos carnívoros y ocasionales visitantes/habitantes (Andrews, 1990).

En este trabajo se presenta por primera vez un estudio completo de los pequeños mamíferos de la secuencia estratigráfica del Mirón y se analiza la evolución de la fauna durante la transición Pleistoceno-Holoceno, la extinción de fauna Pleistocena y la aparición de la fauna moderna en Cantabria. Este análisis permite conocer la evolución del clima y del paisaje en la Cornisa Cantábrica al final del Cuaternario.

\section{LA CUEVA DEL MIRÓN}

El Mirón se encuentra en las proximidades de Ramales de la Victoria, en el valle del Río Asón, en Cantabria (Figs. 1 y 2). Es una cavidad cuya boca tiene cerca de 20 metros de altura, con un desarrollo total de $130 \mathrm{~m}$. Forma parte del sistema cárstico del Monte Pando, donde se desarrollan otras cuevas como La Cullalvera, La Luz, El Horno, La Haza, y Covalanas, éstas dos últimas bien cono- 


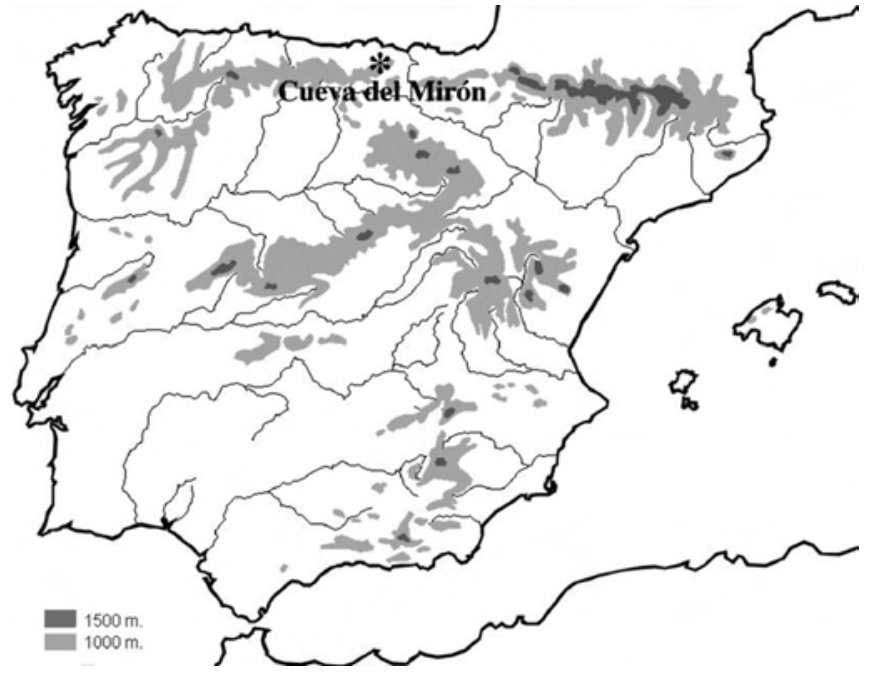

Figura 1. Situación Geográfica del yacimiento Cuaternario de la Cueva del Mirón Geographic situation of the El Mirón Cave Quaternary site.

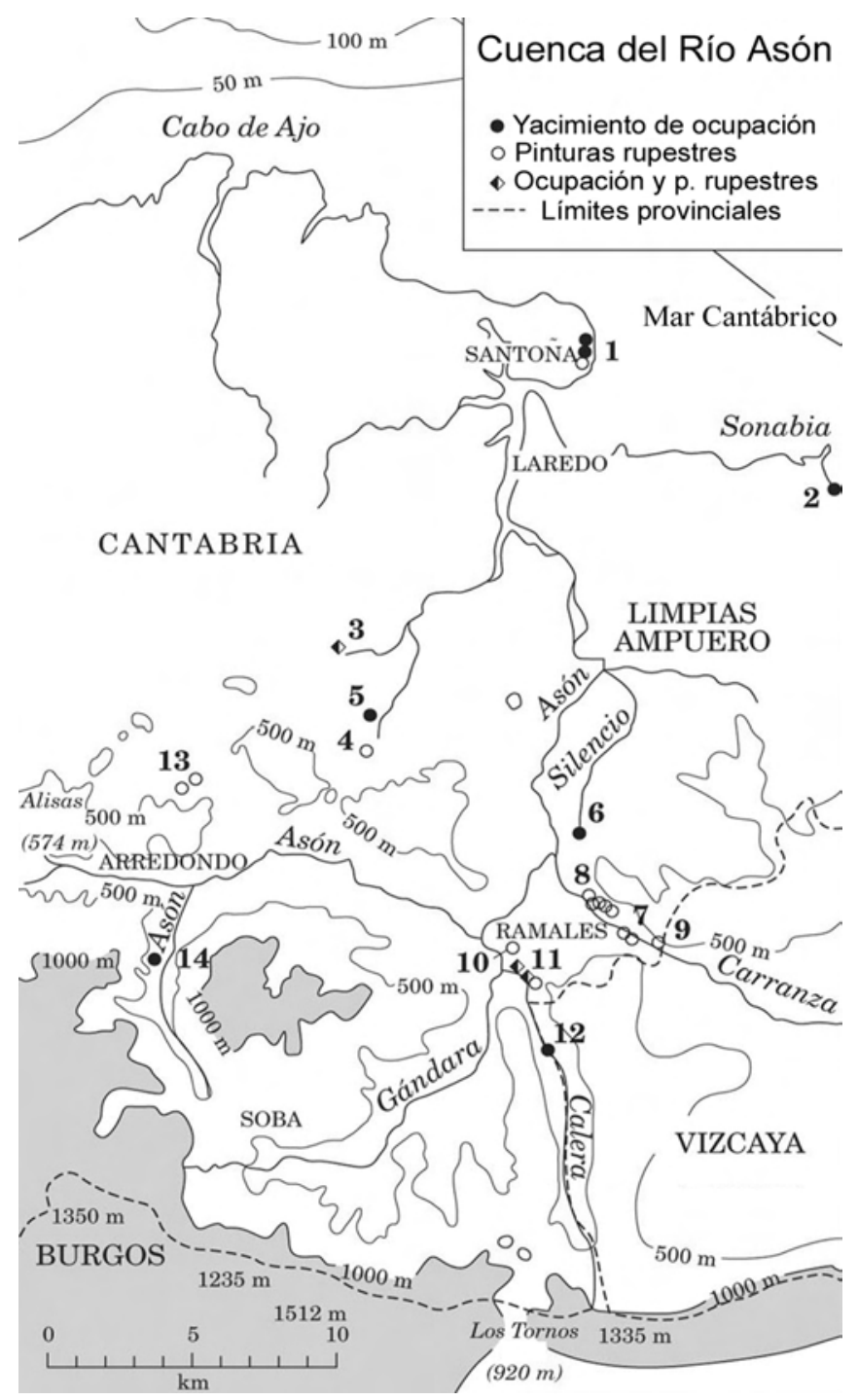

cidas por sus pinturas rupestres de "perfilados con puntos rojos” (León García, 1998; Straus et al., 2006). La Cueva del Mirón se encuentra a $260 \mathrm{~m}$ por encima del actual nivel del mar, a $3^{\circ} 27^{\prime}$ al Oeste de Grenwich y $43^{\circ} 16^{\prime}$ Norte (Figs. 1 y 2). La entrada, estaba orientada hacia poniente y relativamente cerca del litoral (unos $27 \mathrm{~km}$ de la paleolínea de costa) durante el último máximo glacial (LGM: $17 \mathrm{Ka}$ antes del presente, $\mathrm{BP}$ en el resto del texto). Su posición, montana pero cercana al mar, su orientación y su amplitud, pudieron ser las causas de que la cueva del Mirón haya sido utilizada con cierta continuidad por los seres humanos (el hombre de neandertal primero y el hombre moderno después), al menos desde el Musteriense (40 Ka BP) (Straus \& González Morales, 2001a, b, 2003; Altuna et al., 2004; Straus et al., 2006).

La cueva fue descubierta a comienzos del siglo $\mathrm{XX}$, aunque su excavación sistemática comenzó en 1996. Desde entonces, un equipo de unas 15-25 personas excava, durante los dos meses de la campaña de campo, en cuatro zonas distintas (Fig. 3): la Cabaña, la Trinchera, el Corral del gran

Figura 2. La Cuenca Hidrográfica del Río Asón y principales yacimientos Cuaternarios (Paleolíticos y Mesolíticos), así como otros detalles geográficos y políticos. 1: La Fragua, El Perro, San Carlos; 2: La Trecha; 3: El Otero; 4: Cobrantes; 5: La Chora; 6: El Valle; 7: Sotarriza, Covanegra; 8: Morro, Pondra, Arco A, B y C; 9: Venta de la Perra, Polvorín; 10: Cullalvera; 11: Ramales yacimiento de exterior, La Haza, El Mirón, Covalanas, El Horno; 12: Tarrerón; 13: Los Emboscados, Patatal, Cubio Redondo; 14: Cubera. La línea discontínua indica el límite entre las provincias de Burgos, Vizcaya y Cantabria. Este límite marca también el límite geográfico entre la Meseta y la Cordillera Cantábrica, que se comunican por el estrecho paso de Los Tormos, el Camino Real (mapa dibujado por R. Stauber, del original de L.G. Straus).

River Asón Drainage Basin and main Quaternary (Paleolithic and Mesolithic) sites, as well as other political and geographic details. 1: La Fragua, El Perro, San Carlos; 2: La Trecha; 3: El Otero; 4: Cobrantes; 5: La Chora; 6: El Valle; 7: Sotarriza, Covanegra; 8: Morro, Pondra, Arco A, B \& C; 9: Venta de la Perra, Polvorín; 10: Cullalvera; 11: Ramales open-air site, La Haza, El Mirón, Covalanas, El Horno; 12: Tarrerón; 13: Los Emboscados, Patatal, Cubio Redondo; 14: Cubera. Legend: Black circles, habitation site; blawhite circless, cave art sitess; black and white losanges, cave art and habitation sites. The striped line in the South marks the limit between Burgos, Vizcaya and Cantabria. This limit is also the geographic boundary between the Upland Spain and the Cantabrian Mountains, that are communicated by the Los Tormos Pass, The Real Road. (drawing of $R$. Stauber, after an original of L.G. Straus). 


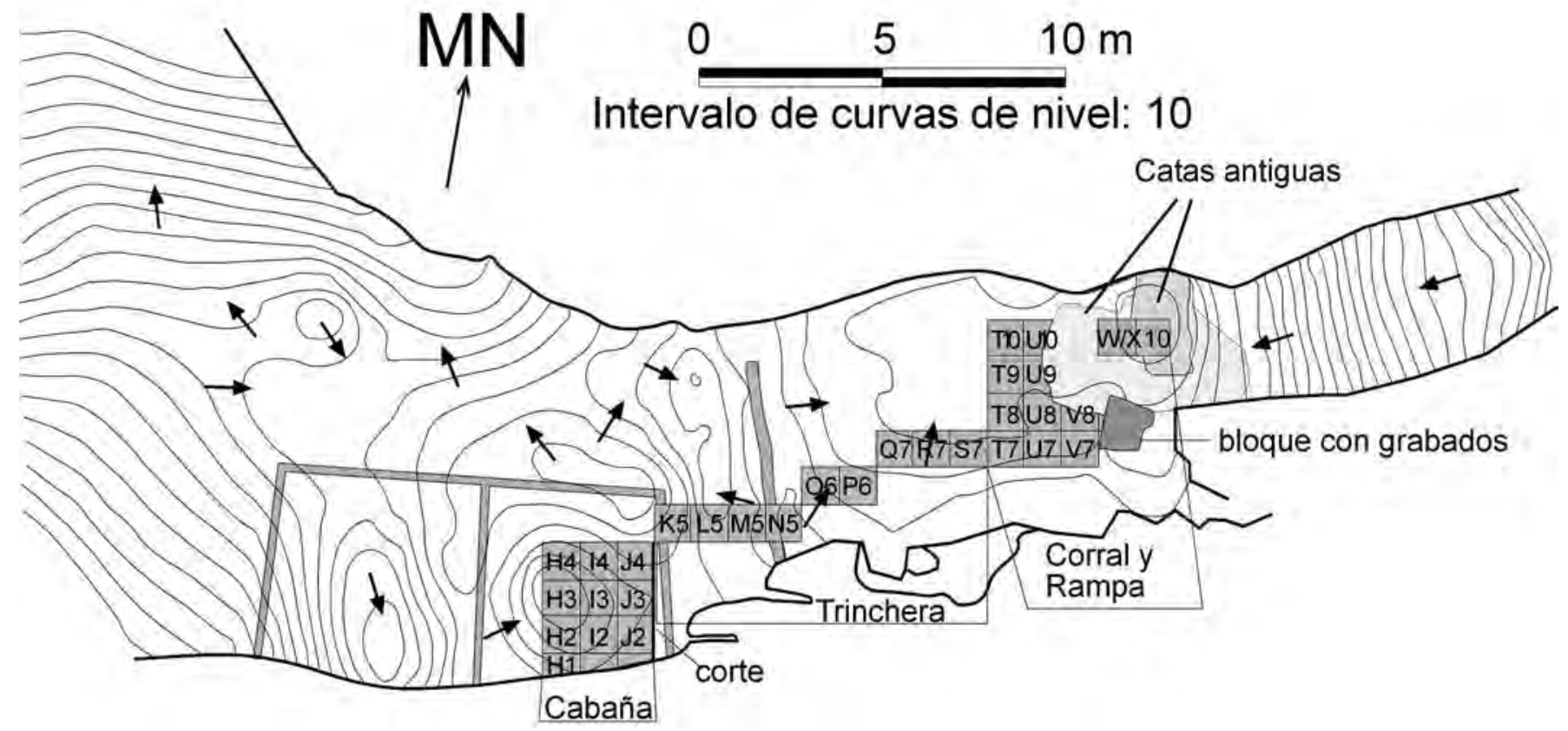

Figura 3. Plano de la Cueva del Mirón. Las zonas de excavación son, de Oeste a Este: Cabaña (Cuadros H-K); Trinchera (Cuadros L-P); Corral (Cuadros Q-V) y el Sondeo de la Rampa (cuadros W-X) que comunica el Vestíbulo de la Cueva del Mirón con la zona hipogea, oscura.

Map of the El Mirón site. The excavation areas are, from West to East: Cabin or Outer Vestibule or Vestibule Front (Squares H-K); Trench or Mid-vestibule Trench (Squares L-P); Vestibule Rear (Squares Q-V), and the Sondage of the Footslope (Squares $W-X)$ that communicates the Vestibule of El Mirón with the dark zone of the Cave.

vestíbulo soleado y la Rampa, una pendiente erosional que sube hacia la parte interior y oscura de la caverna (Straus \& González Morales, 2001a, b, y en este trabajo).

\section{ESTRATIGRAFÍA Y DISTRIBUCIÓN DE LA MICROFAUNA EN LA SECUENCIA DEL MIRÓN}

Courty \& Valverdú (2001) y Straus et al. (2001) describen en detalle ciertos aspectos sedimentológicos y estratigráficos de la Cueva del Mirón que completan la descripción que damos en este trabajo. Se sigue una descripción algo distinta de la utilizada tradicionalmente en geología pues empezamos describiendo los niveles desde el techo hasta la base de la excavación, la cual no coincide con la de la sección; ya que no se ha alcanzado el sustrato rocoso en ninguna de las zonas (Figs. 3 a 7). La prospección geofísica que hizo el Dr. Jaime Clapés nos indica que la base se encuentra a $9 \mathrm{~m}$ de profundidad (a partir de la superficie inicial de la cueva, en el Corral). Hasta ahora se ha exca- vado una profundidad que varía de 3 a $5 \mathrm{~m}$. La potencia de los niveles es variable (Figs. 4 a 7). El número de muestras para el análisis de los micromamíferos tomado en cada nivel responde más a la estrategia de la excavación arqueológica que a un muestreo paleontológico. Por ejemplo, en los niveles en los que los materiales arqueológicos son muy abundantes, hay un número de muestras mayor puesto que la excavación se divide en un número mayor de "tallas" o tramos arqueológicos (spits). Debido a su gran superficie, la excavación, se ha dividido en cuatro zonas (Fig. 3). La distribución estratigráfica de las asociaciones de pequeños mamíferos se muestra en las Tablas 1 y 2. Para facilitar la lectura, la cronología de los Niveles Culturales del final del Cuaternario se sintetiza en la Tabla 3.

Zona de la Cabaña (Outer or Vestibule Front). Cuadros $\mathrm{H}-\mathrm{K} / 1-4$

Descripción de los niveles, 1 a 17, de techo a base (Fig. 4):

Nivel 1: Nivel gris de relleno final de cueva, compuesto por materia orgánica procedente de la cabaña reciente y bloques de la caliza de las paredes y techo de la cueva. Nivel de ocupación actual.

Tabla 1. Listado de los pequeños mamíferos actuales de la Cornisa Cantábrica (izquierda), y del registro fósil del Cuaternario del Mirón (derecha). La columna central es la de los autores de los taxones.

In the first column is the inventory of the extant small mammals of the Cantabrian Region, Spain. In the third column are these in the fossil record of the Quaternary of El Mirón. The central column gives the name of the author of each taxa. 


\begin{tabular}{|c|c|c|}
\hline Cuaternario El Mirón & Autor & Actual Región Cántabra \\
\hline Orden Erinaceomorpha & Gregory, 1910 & \\
\hline Familia Erinaceidae & Fischer von Waldheim, 1817 & \\
\hline Erinaceus europaeus & Linnaeus, 1758 & Erinaceus europaeus \\
\hline Orden Soricomorpha & Gregory, 1910 & \\
\hline Familia Soricidae & Fischer von Waldheim, 1817 & \\
\hline \multirow[t]{2}{*}{ Crocidura russula } & (Hermann, 1780) & Crocidura russula \\
\hline & (Pallas, 1811) & Crocidura suaveolens \\
\hline Neomys fodiens & (Pennant, 1771) & Neomys fodiens \\
\hline Sorex minutus & Linnaeus, 1766 & Sorex minutus \\
\hline \multicolumn{3}{|l|}{ Sorex gr. coronatus-araneus } \\
\hline & Linnaeus, 1758 & Sorex araneus \\
\hline & Millet, 1828 & Sorex coronatus \\
\hline & (Savi, 1822) & Suncus etruscus \\
\hline Familia Talpidae & Fischer von Waldheim, 1817 & \\
\hline Galemys pyrenaicus & (E. geoffroy, 1811) & Galemys pyrenaicus \\
\hline Talpa europaea & Linnaeus, 1758 & Talpa europaea \\
\hline Orden Chiroptera & Blumenbach, 1779 & \\
\hline \multicolumn{3}{|l|}{ Quiroptera indet. } \\
\hline Familia Vespertilionidae & Gray, 1821 & \\
\hline \multirow[t]{13}{*}{ Myotis } & Kaup, 1829 & Myotis \\
\hline & (Borkhausen, 1797) & Myotis myotis \\
\hline & (Kuhl, 1817) & Myotis bechsteinii \\
\hline & (E. Geoffroy, 1806) & Myotis emarginatus \\
\hline & (Tomes, 1857) & Myotis blythii \\
\hline & (Kuhl, 1817) & Myotis nattereri \\
\hline & (Schreber, 1774) & Barbastella barbastellus \\
\hline & (Schreber, 1774) & Eptesicus serotinus \\
\hline & (Kuhl, 1817) & Nyctalus leisleri \\
\hline & (Schreber, 1774) & Nyctalus noctula \\
\hline & (Keyserling y Blasius, 1839) & Pipistrellus nathusii \\
\hline & (Linnaeus, 1758) & Plecotus auritus \\
\hline & (Fischer, 1829) & Plecotus austriacus \\
\hline \multirow[t]{4}{*}{ Familia Rhinolophidae } & Gray, 1825 & \\
\hline & Blasius, 1853 & Rhinolophus euryale \\
\hline & (Schreber, 1774) & Rhinolophus ferrumequinum \\
\hline & (Bechstein, 1800) & Rhinolophus hipposideros \\
\hline \multirow[t]{2}{*}{ Familia Molossidae } & Gervais, 1856 & \\
\hline & (Rafinesque, 1814) & Tadarida teniotis \\
\hline Familia Miniopteridae & Dobson, 1875 & \\
\hline Miniopterus schereibersii & (Kuhl, 1817) & Miniopterus schereibersii \\
\hline Orden Carnivora & Bowdich, 1779 & \\
\hline Familia Mustelidae & Fischer von Waldheim, 1817 & \\
\hline Mustela nivalis & Linnaeus, 1766 & Mustela nivalis \\
\hline Orden Rodentia & Griffith, 1827 & \\
\hline Familia Sciuridae & Hemprich, 1820 & \\
\hline Sciurus vulgaris & Linnaeus, 1758 & Sciurus vulgaris \\
\hline Familia Muridae & Illiger, 1815 & \\
\hline Subfamilia Arvicolinae & Gray, 1821 & \\
\hline Arvicola terrestris & Linnaeus, 1758 & Arvicola terrestris cantabrae \\
\hline Arvicola sapidus & Miller, 1908 & Arvicola sapidus \\
\hline Chionomys nivalis & (Martins, 1842) & Chionomys nivalis \\
\hline Clethrionomys glareolus & (Schreber, 1780) & Clethrionomys glareolus \\
\hline Microtus agrestis & (Linnaeus, 1761) & Microtus agrestis \\
\hline Microtus arvalis & (Pallas, 1778) & Microtus arvalis asturianus \\
\hline Microtus oeconomus & (Pallas, 1776) & \\
\hline \multirow[t]{2}{*}{ Microtus gregalis } & Pallas, 1779 & \\
\hline & & Terricola pyrenaicus-gerbei \\
\hline Terricola lusitanicus & (Gerbe, 1879) & Terricola lusitanicus \\
\hline Pliomys lenki & Heller, 1930 & \\
\hline Subfamilia Murinae & Illiger, 1815 & \\
\hline \multicolumn{3}{|c|}{ Apodemus sylvaticus-flavicollis } \\
\hline & (Melchior, 1834) & Apodemus flavicollis \\
\hline & (Linnaeus, 1758) & Apodemus sylvaticus \\
\hline & (Pallas, 1771) & Micromys minutus \\
\hline & Linnaeus, 1758 & Mus musculus \\
\hline & Lataste, 1883 & Mus spretus \\
\hline & (Berkenhout, 1769) & Rattus norvegicus \\
\hline & (Linnaeus, 1758) & Rattus rattus \\
\hline Familia Myoxidae & Gray, 1821 & \\
\hline Eliomys quercinus & (Linnaeus, 1766) & Eliomys quercinus \\
\hline Myoxus glis & (Linnaeus, 1766) & Myoxus glis \\
\hline Orden Lagomorpha & Brandt, 1855 & \\
\hline \multirow[t]{3}{*}{ Familia Leporidae } & Fischer von Waldheim, 1817 & \\
\hline & Pallas, 1778 & Lepus europaeus \\
\hline & (Linnaeus, 1758) & Oryctolagus cuniculus \\
\hline
\end{tabular}




\begin{tabular}{|c|c|c|c|c|c|c|c|c|c|c|c|c|c|c|c|c|c|c|c|c|c|c|c|c|c|c|c|c|}
\hline 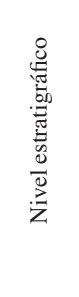 & 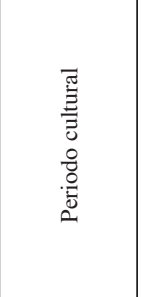 & 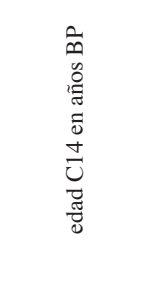 & 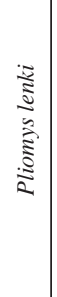 & 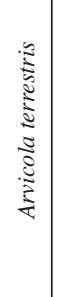 & 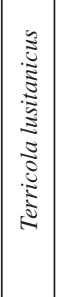 & 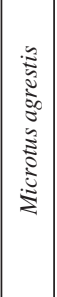 & 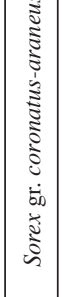 & 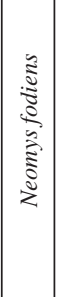 & 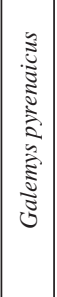 & 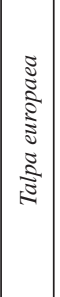 & 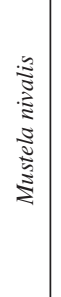 & 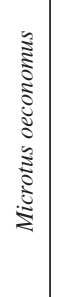 & 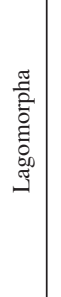 & 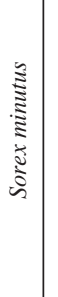 & 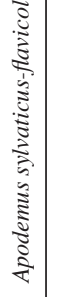 & 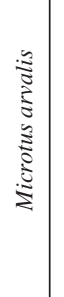 & 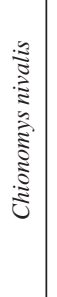 & 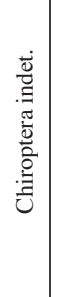 & 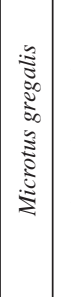 & 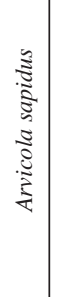 & 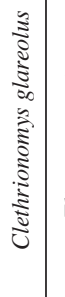 & 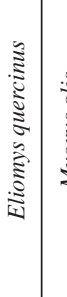 & 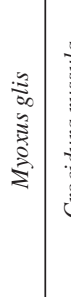 & 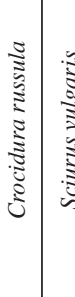 & | & 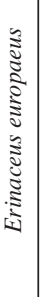 & 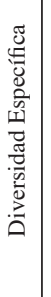 & \\
\hline 1 & \multirow{6}{*}{ 芯 } & $1.100-1.400$ & & $\mathrm{X}$ & & & & & & $\mathrm{X}$ & & & & & & & & & & & & & & & & & 2 & $\frac{2}{2}$ \\
\hline 2 & & $1.100-1.401$ & & $\mathrm{X}$ & & & & & & & & & $\mathrm{X}$ & & & & & & & & & & & & & & 2 & \\
\hline $2+3$ & & & & $X$ & & & & & & $\mathrm{X}$ & & $\mathrm{x}$ & & & & & & & & & & & & & & & 3 & $\begin{array}{l}3 \\
33\end{array}$ \\
\hline 3 & & 3.700 & & $X$ & $\mathrm{x}$ & $\mathrm{X}$ & $X$ & $\mathrm{X}$ & & $\mathrm{X}$ & & $\mathrm{x}$ & & & $\mathrm{X}$ & $\mathrm{X}$ & $\mathrm{X}$ & $\mathrm{X}$ & & & $\mathrm{X}$ & & $\mathrm{X}$ & $\mathrm{X}$ & & & 14 & $\frac{33}{1}$ \\
\hline$\frac{3.2}{3.3}$ & & & & $\mathrm{x}$ & & & & & & & & & & & $\frac{X}{x}$ & & & & & & & & & & & & $\frac{1}{2}$ & $\frac{1}{3}$ \\
\hline 3.4 & & & & $\frac{x}{X}$ & 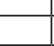 & & & 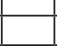 & & $\mathrm{X}$ & & - & & & $x$ & & & & & & 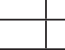 & & & & & & 2 & $\frac{3}{2}$ \\
\hline 3.5 & & & & & & & & & & & & & & & $x$ & & & & & & $x$ & & & & & & $\frac{2}{7}$ & $\begin{array}{l}1 \\
10\end{array}$ \\
\hline 4 & & & & $\mathrm{X}$ & & & $\mathrm{x}$ & & & $\mathrm{X}$ & $x$ & & & & $\mathrm{X}$ & $\mathrm{X}$ & & & & & & & $\frac{X}{y}$ & & & & 7 & $\frac{19}{20}$ \\
\hline 5 & & 3.820 & & $\mathrm{X}$ & & & $\mathrm{X}$ & $\mathrm{X}$ & & $\mathrm{X}$ & $x$ & $\mathrm{X}$ & $\mathrm{X}$ & & $\mathrm{X}$ & $\mathrm{X}$ & & & & & $\mathrm{X}$ & & $\mathrm{X}$ & & & & 11 & $\frac{30}{7}$ \\
\hline 5.1 & & 4.120 & & $\mathrm{x}$ & $\mathrm{x}$ & $\mathrm{X}$ & & & & & & & & & $\mathrm{X}$ & $\mathrm{X}$ & & & & & & & $x$ & & & & 6 & \\
\hline 5.2 & & & & & & & & & & & & & & & $X$ & & & & & & & & $\begin{array}{ll}x \\
\end{array}$ & & & & $\frac{2}{2}$ & 2 \\
\hline 5.4 & & & & & & & & & & & 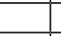 & 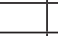 & & & $X$ & & $\mathrm{X}$ & & & & & & $\mathrm{x}$ & & & & 3 & 5 \\
\hline 6 & $\frac{8}{\sigma}$ & - & & $\mathrm{X}$ & $\square$ & $X$ & $X$ & $\mathrm{X}$ & & $\mathrm{X}$ & & & $\mathrm{X}$ & & $\mathrm{X}$ & & $\mathrm{X}$ & & & & $\mathrm{X}$ & $\mathrm{X}$ & $\mathrm{X}$ & & & & 11 & $\frac{29}{29}$ \\
\hline$\frac{6.1}{7}$ & & 3.740 & & & - & & & & & & & & & & $\mathrm{X}$ & & & & & & & & \begin{tabular}{l|l}
$x$ \\
$y$
\end{tabular} & & & & $\frac{2}{9}$ & $\frac{2}{28}$ \\
\hline 7.1 & & & & & 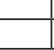 & $x$ & $x$ & 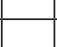 & & $\mathrm{X}$ & & & & & $\frac{X}{X}$ & - & $X$ & & & & - & $\mathrm{x}$ & $\frac{X}{X}$ & $\frac{X}{X}$ & & $\mathrm{X}$ & $\frac{9}{3}$ & $\frac{28}{2}$ \\
\hline 7.2 & & & & & & 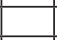 & 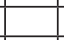 & 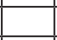 & & $\mathrm{X}$ & & & & & $\mathrm{X}$ & & & & & & & & & & & & 2 & \\
\hline 7.4 & & & & & & & & & & & & & & & & & & & & & & & $\mathrm{X}$ & & & & 1 & 1 \\
\hline 7.5 & & & & & & & & & & $\mathrm{X}$ & & & & & & & & & & & & & & & & & 1 & \\
\hline 8 & & & & $\mathrm{X}$ & $\mathrm{X}$ & $\mathrm{X}$ & & $\mathrm{X}$ & & $\mathrm{X}$ & & & & & $\mathrm{X}$ & $\mathrm{X}$ & $\mathrm{X}$ & $\mathrm{X}$ & & & $\mathrm{X}$ & $\mathrm{X}$ & $\mathrm{X}$ & $\mathrm{X}$ & & & 13 & 17 \\
\hline 9 & & $5.170-5.280$ & & $\mathrm{X}$ & $\mathrm{X}$ & $\mathrm{X}$ & $\mathrm{X}$ & & & $\mathrm{X}$ & & & & & $\mathrm{X}$ & & $\mathrm{X}$ & & & & $\mathrm{X}$ & $\mathrm{X}$ & $\mathrm{X}$ & & & & 10 & \\
\hline 9.6 & & 5.250 & & & $x$ & $\mathrm{x}$ & & 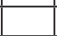 & & $\mathrm{X}$ & & & & & $\mathrm{X}$ & $\mathrm{X}$ & $\mathrm{X}$ & & & & $\mathrm{X}$ & & $\mathrm{x}$ & & & & 8 & 17 \\
\hline 9.7 & 8 & & & $\mathrm{X}$ & $\mathrm{X}$ & $\mathrm{x}$ & - & & & $\mathrm{X}$ & & & & & $\mathrm{X}$ & & & & & & $\mathrm{X}$ & & $\mathrm{x}$ & & & & 7 & 8 \\
\hline 9.8 & & & & & $\mathrm{X}$ & & $\mathrm{X}$ & & & $\mathrm{X}$ & & & & & $\mathrm{X}$ & $\mathrm{X}$ & $\mathrm{X}$ & & & & $\mathrm{X}$ & & & & & & 8 & \\
\hline 303 & & 5.500 & & $\mathrm{X}$ & & 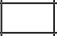 & & & & $\mathrm{X}$ & & $X$ & & & $\mathrm{X}$ & & & & & & & & $\bar{X}$ & & & & 5 & 5 \\
\hline 303.1 & & 5.520 & & & & & & & & & & & & & $\mathrm{X}$ & & & & & & & & $\mathrm{X}$ & & & & 2 & 2 \\
\hline 10 & Mes, & $5.570-5.690$ & & $\mathrm{X}$ & $\mathrm{X}$ & $\mathrm{X}$ & $\mathrm{X}$ & $X$ & & $\mathrm{X}$ & $\mathrm{X}$ & & & $\mathrm{X}$ & $\mathrm{X}$ & $\mathrm{X}$ & $\mathrm{X}$ & $\mathrm{X}$ & & $X$ & $\mathrm{X}$ & $\mathrm{X}$ & $\mathrm{X}$ & $\mathrm{X}$ & & & 17 & 31 \\
\hline 10.1 & Mes. & $8.380-9.550$ & & $X$ & $\mathrm{X}$ & $\mathrm{X}$ & $\mathrm{X}$ & $\mathrm{x}$ & & $\mathrm{X}$ & $\mathrm{X}$ & $\mathrm{X}$ & & $\underline{x}$ & $\mathrm{X}$ & & $\mathrm{X}$ & & & & $\mathrm{X}$ & $\mathrm{X}$ & $\mathrm{X}$ & $\mathrm{X}$ & $\mathrm{X}$ & & 16 & 15 \\
\hline 304 & & & & $X$ & $\mathrm{X}$ & & $\mathrm{X}$ & $\mathrm{X}$ & & $\mathrm{X}$ & & & & & $X$ & & $\mathrm{X}$ & & & & $\mathrm{X}$ & & $\mathrm{X}$ & $\mathrm{X}$ & & & 10 & 4 \\
\hline 102.1 & 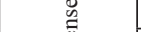 & 11.950 & & $\mathrm{X}$ & $\mathrm{X}$ & $X$ & $\mathrm{x}$ & & & $\mathrm{X}$ & & & & & $\mathrm{X}$ & $\mathrm{X}$ & & & & & & & & & & & 8 & 5 \\
\hline 102.2 & $\stackrel{\bar{\Xi}}{=}$ & & & $\mathrm{X}$ & $\mathrm{X}$ & & & $\mathrm{X}$ & & $\mathrm{X}$ & & & & & $\mathrm{X}$ & $\mathrm{X}$ & $X$ & & & & & & $\mathrm{X}$ & & & & 8 & 5 \\
\hline 104 & $\sqrt{x}$ & & & $\mathrm{X}$ & & 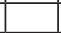 & $\mathrm{X}$ & & & $\mathrm{X}$ & $\mathrm{X}$ & & & & $\mathrm{X}$ & $\mathrm{X}$ & $\mathrm{X}$ & $\mathrm{X}$ & & & & & & & & & 8 & 16 \\
\hline 104.2 & & & & $\mathrm{X}$ & & & & & & & & & & & $\mathrm{X}$ & $\mathrm{X}$ & & $\mathrm{X}$ & & & & & & & & & 4 & 2 \\
\hline 305 & & 10.270 & & $\bar{x}$ & & & & & & $X$ & & & & & $\mathrm{X}$ & & $\mathrm{X}$ & & & & & $\mathrm{X}$ & $X$ & & & & 6 & 6 \\
\hline 306 & & 11.650 & & $\mathrm{X}$ & & $\mathrm{X}$ & $\mathrm{X}$ & & & $\mathrm{X}$ & & & & & $\mathrm{X}$ & $\mathrm{X}$ & $\bar{X}$ & & & & & & & & & & 7 & 7 \\
\hline 11 & & & & $\mathrm{X}$ & $\mathrm{X}$ & $\mathrm{X}$ & $\mathrm{X}$ & $x$ & & $\mathrm{X}$ & $\mathrm{x}$ & & & & $\mathrm{X}$ & & $\underline{x}$ & & & & $\mathrm{X}$ & & $\mathrm{X}$ & & & & 11 & 15 \\
\hline 11.1 & & 11.720 & & $\mathrm{X}$ & $\mathrm{X}$ & $\mathrm{X}$ & $\mathrm{x}$ & $\mathrm{X}$ & & $\mathrm{X}$ & & & & & $\mathrm{X}$ & $\mathrm{X}$ & & & & & & & & & & & 9 & 8 \\
\hline 11.2 & & & & $\mathrm{X}$ & $\mathrm{X}$ & $\mathrm{X}$ & & & & $X$ & & & & & $\mathrm{X}$ & $\mathrm{X}$ & & & & & & $\mathrm{X}$ & & & & & 8 & 4 \\
\hline 10 & & 12.460 & $x$ & $\mathrm{X}$ & $\mathrm{X}$ & $\mathrm{X}$ & $\mathrm{X}$ & & & $\mathrm{X}$ & & $\mathrm{X}$ & & & $\mathrm{X}$ & & & & & & & & & & & & 10 & 37 \\
\hline 107 & & & & $\mathrm{x}$ & $\mathrm{X}$ & $\mathrm{X}$ & $\mathrm{X}$ & & & $\mathrm{X}$ & $\mathrm{X}$ & & & & $\mathrm{X}$ & $x$ & $x$ & $\mathrm{X}$ & & & & & & & & & 11 & 21 \\
\hline 107.1 & & & & $\mathrm{X}$ & & $\mathrm{X}$ & & & & $\mathrm{X}$ & $\mathrm{X}$ & & & & $\mathrm{X}$ & $\mathrm{X}$ & $X$ & & & & & & & & & & 8 & 6 \\
\hline 12 & @ & 12.790 & & $\mathrm{X}$ & $\mathrm{X}$ & $\mathrm{X}$ & 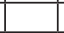 & & & $\mathrm{X}$ & $\mathrm{X}$ & $\mathrm{X}$ & & & $\mathrm{X}$ & $\mathrm{X}$ & $\mathrm{X}$ & $\mathrm{X}$ & & & & $\mathrm{X}$ & & & & & 11 & 16 \\
\hline 13 & & & & $\mathrm{X}$ & $\mathrm{x}$ & $\mathrm{X}$ & $\mathrm{X}$ & & & $\mathrm{X}$ & & & & & & $\mathrm{X}$ & $\mathrm{X}$ & & & & & & & & & & 8 & 42 \\
\hline 14 & 击 & 14.600 & & $\bar{x}$ & & $\mathrm{X}$ & $\mathrm{X}$ & & & & & & & $\mathrm{x}$ & & & & & & & & & & & & & 9 & \\
\hline 108 & :̊ & $13.660-14.850$ & $\mathrm{X}$ & $\bar{x}$ & & $\mathrm{X}$ & $\mathrm{X}$ & $X$ & & $\underline{X}$ & & & & & $\mathrm{X}$ & $x^{x}$ & 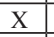 & $\mathrm{X}$ & & & $\mathrm{X}$ & $\mathrm{X}$ & $\mathrm{X}$ & $\mathrm{X}$ & & & 17 & 48 \\
\hline 109 & $\sum_{\Sigma}^{\circ}$ & & $\mathrm{X}$ & $\underline{x}$ & $\mathrm{X}$ & $\mathrm{X}$ & & & & $\bar{x}$ & & $\Lambda$ & & $\mathrm{X}$ & $\mathrm{X}$ & & & & & & & & & & & & 10 & 11 \\
\hline 15 & & $15.010-15.220$ & & $x$ & & & $\mathrm{X}$ & & & $\mathrm{x}$ & & & & & & & & & & & & & & & & & 6 & 17 \\
\hline 16 & 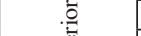 & & & $\mathrm{X}$ & $\mathrm{X}$ & $\mathrm{X}$ & & & & $X$ & & $\mathrm{X}$ & & & & $\mathrm{X}$ & & & & & & & & & & & 7 & 26 \\
\hline 17 & 党 & 15.370 & & $\mathrm{x}$ & $\mathrm{X}$ & & & $\mathrm{X}$ & & $\mathrm{X}$ & $\mathrm{X}$ & & & & & & & & & $\mathrm{X}$ & & & & & & & 6 & 3 \\
\hline 110 & $\Xi$ & 16.130 & $\mathrm{X}$ & $\mathrm{x}$ & $\mathrm{X}$ & $\mathrm{X}$ & $\mathrm{X}$ & $\mathrm{X}$ & & $\mathrm{X}$ & $\mathrm{X}$ & $\mathrm{X}$ & & & & $\mathrm{X}$ & $\mathrm{X}$ & $\mathrm{X}$ & & & & & & & & & 12 & 37 \\
\hline 111 & $\frac{0}{0}$ & $15.530-16.370$ & & $\mathrm{X}$ & $\mathrm{X}$ & $\mathrm{X}$ & $\mathrm{X}$ & & & $\mathrm{X}$ & $\mathrm{X}$ & $\mathrm{X}$ & $\mathrm{X}$ & & $\mathrm{X}$ & $\mathrm{X}$ & $\mathrm{X}$ & & & & & & & & & & 11 & 27 \\
\hline 112 & $\cong$ & & & $\mathrm{X}$ & $\mathrm{X}$ & $\mathrm{X}$ & $\mathrm{X}$ & & & $\mathrm{X}$ & & $\mathrm{X}$ & & & $\mathrm{X}$ & $\mathrm{X}$ & $\mathrm{X}$ & & & & & & & & & & 9 & 7 \\
\hline 113 & $\frac{\frac{2}{\pi}}{\frac{\pi}{\pi}}$ & & & $\mathrm{X}$ & $\mathrm{X}$ & & & & & $\mathrm{X}$ & $\mathrm{x}$ & $\mathrm{X}$ & & $\mathrm{X}$ & & $\mathrm{X}$ & $\mathrm{X}$ & & & & & & & & & & 9 & 3 \\
\hline 114 & & 16.460 & & $\bar{x}$ & & & $\mathrm{X}$ & & & $\mathrm{X}$ & & & & & & & & & & & & & & & & & 6 & 6 \\
\hline 115 & $\bar{z}$ & & & $\mathrm{X}$ & $\mathrm{X}$ & & $\mathrm{X}$ & & & & & & & & & 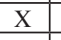 & $\mathrm{X}$ & & & & & & & & & & 7 & 4 \\
\hline 116 & & $15.220-17.400$ & & $\bar{x}$ & & $\mathrm{X}$ & & & & & & & & & & & & & & & & & & & & & 4 & \\
\hline 12 & & & $\mathrm{X}$ & $\underline{X}$ & & $\mathrm{X}$ & & & & $\mathrm{X}$ & $\mathrm{X}$ & & & $X$ & & & $\mathrm{x}$ & & & & & & & & & & 8 & \\
\hline 121 & 幽 & 18.390 & $\mathrm{x}$ & $\mathrm{X}$ & $\mathrm{X}$ & & & & & & $\mathrm{X}$ & & & & & & $\mathrm{X}$ & & & & & & & & & & 6 & 1 \\
\hline 12 & & & & $\mathrm{X}$ & $x$ & $x$ & & & & & & & & & & $\mathrm{x}$ & & & & & & & & & & & 5 & 1 \\
\hline 123 & D & & & & & & & & & $\mathrm{X}$ & & $\mathrm{X}$ & & & & $\mathrm{x}$ & & & & & & & & & & & 4 & 1 \\
\hline 124 & & & $x$ & $\mathrm{X}$ & & & & $\mathrm{X}$ & & $\mathrm{X}$ & $\mathrm{X}$ & $\mathrm{X}$ & & & & $\mathrm{X}$ & & $\mathrm{X}$ & & & & & & & & & 8 & 2 \\
\hline 125 & & 18.980 & & 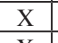 & & $x$ & & & & $x$ & & & & $\mathrm{x}$ & & $x$ & & & & & & & & & & & 5 & 1 \\
\hline 126 & & & $\mathrm{X}$ & $\underline{X}$ & $X$ & $X$ & $x$ & $\mathrm{X}$ & & $\mathrm{X}$ & & $X$ & & $\mathrm{X}$ & & $\mathrm{X}$ & X & & & & & & & & & & 10 & 2 \\
\hline 128 & ivetiense & 27.580 & & & $\mathrm{X}$ & $\mathrm{X}$ & & & & $\mathrm{X}$ & $\mathrm{X}$ & $\mathrm{X}$ & $x$ & $X$ & $\mathrm{X}$ & $X$ & $\mathrm{X}$ & & & & & & & & & & 11 & \\
\hline 129 & & & $\underline{x}$ & $\overline{\underline{x}}$ & & & & & & & & & & & & & & & & & & & & & & & 3 & 1 \\
\hline 130 & Musteriense & 41.280 & $x$ & X & $\mathrm{x}$ & $\mathrm{x}$ & $\mathrm{x}$ & $\mathrm{X}$ & $\frac{x}{x}$ & $\mathrm{x}$ & $\mathrm{X}$ & & & & & & & & & & & & & & & & 9 & 1 \\
\hline do $\mathrm{N}$ & & $1.100-41.280$ & 33 & |693 & [170 & 229 & $\mid 114$ & 46 & 1 & |419| & 25 & 96 & 10 & 14 & & 192 & 172 & $17 \mid$ & & & \begin{tabular}{l|l}
56 & 2 \\
5
\end{tabular} & & & & & & 24 & 721 \\
\hline
\end{tabular}


Nivel 2: Color beige. Constituye una mezcla con el suelo de la cabaña reciente. Está constituido por arcilla, arena y bloques de piedra. Abundan huesos de grandes mamíferos domésticos.

Conjunto 3: Complejo de niveles numerados del 3 al 3.4, con $14 \mathrm{~cm}$ de potencia en total. Son niveles discontinuos de arcilla, que varían de color gris oscuro a claro, blanco, crema amarillo e incluso rojo. Tienen en común el aumento de la diversidad de pequeños mamíferos con respecto a los niveles 1 y 2 . Mención aparte merece el sub-nivel 3.5, un relleno de canal o trinchera antrópica, que erosiona a los niveles $7,6,5,4,3$ y 3.2, por lo que parece un evento posterior a todos ellos (Fig. 4). Aparentemente, los niveles actuales 1 y 2 se encuentran encima de 3.5 por lo que sería anterior a éstos. Su formación podría estar ligada a la fase de acumulación de la edad del hierro, conocida como Edad Fría del Bronce (2900-2300 ka BP). Ha sido detectada en el NE de España en medios abiertos (Gutiérrez Elorza \& Peña-Monné, 1998) y descrita como un momento frío y húmedo, coincidente con la expansión de los glaciares y una mayor precipitación, previa al período cálido Subatlántico, que sería un período erosivo.

Nivel 4: Horizonte de incendios o fuegos (fumiers) en el que alternan lentejones de ceniza gris-blanquecina cementada localmente. Tiene niveles de carbones y fragmentos quemados de madera y bloques de piedras quemados y agrietados por el fuego. Hay cerámica alrededor, alguna quemada. Hay perforaciones o ¿madrigueras? bordeando alguna de las hogueras. Los pequeños mamíferos son menos diversos en este nivel (Tabla 2) que en el Complejo 3.

Conjunto 5: conjunto de niveles oscuros de limo arcilloso gris-marrón con materia orgánica abundante y carbón. Comprende los sub-niveles 5 y 5.1 a 5.4. El 5 es el más rico en restos de pequeños vertebrados.

Conjunto 6: nivel de ceniza blanca con fragmentos de carbón. Aunque hay también un nivel 6.1, la microfauna sólo se encuentra en 6.

Conjunto 7: es también un complejo formado por los sub-niveles 7 a 7.5. Está compuesto fundamentalmente por ceniza rica en materia orgánica con fragmentos de carbón. En 7 predomina una arcilla limosa, de interior de cueva. La microfauna es escasa y representa un cambio con respecto a otros niveles (Tabla 2). Los arvicolinos disminuyen, siendo el único nivel en el que falta la rata de agua norteña, Arvicola terrestris (Linnaeus, 1758).

Conjunto 8: De color claro, con dos unidades, la 8, arcilla gris-beige con fragmentos de carbón y la 8.1, lentejón de ceniza con carbón y fragmentos de roca. Los pequeños mamíferos sólo están en 8. Es uno de los pocos niveles con evidencias directas de agricultura, por el hallazgo de granos de trigo, al igual que en los niveles 303, 303.2, 303.3 de la Trinchera (Peña-Chocarro et al., 2005).

Conjunto 9: Compuesto por 9 unidades, 9 a 9.8, de arcilla con cenizas y carbón.

Nivel 10: Limo blanco con más continuidad lateral que la que presentan los niveles anteriores, es de carácter menos lenticular.

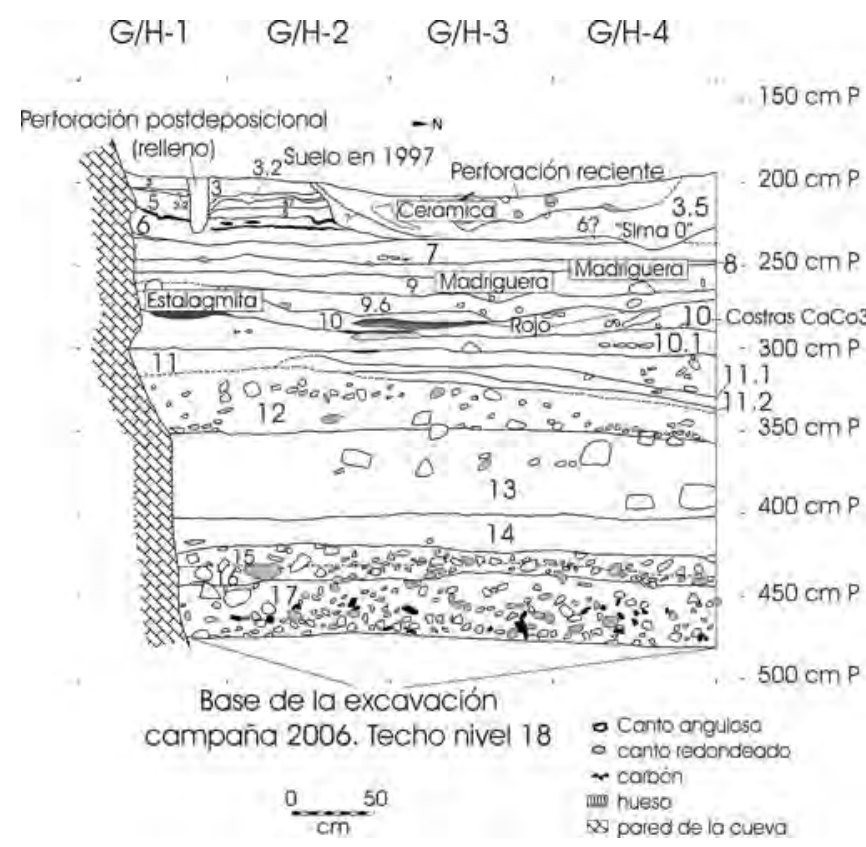

Figura 4. Estratigrafía de la Zona de la Cabaña. Los niveles están representados por los números dentro del esquema estratigráfico. Los números de la Columna de la derecha indican la profundidad de excavación en centímetros (cm P).

Stratigraphy of the Outer Vestibule or Cabin Area. The levels are represented by the numbers inside the stratigraphic scheme. The numbers at the rigth column indicate the deepness of the excavation in $\mathrm{cm}$ (cm P).

Nivel 10.1: Formado por arcilla limosa con ceniza. Tiene de 8 a $9 \mathrm{~cm}$ de potencia. Al igual que el nivel 10 tiene más continuidad lateral que los niveles anteriores. Los niveles 10 y 10.1 son litológicamente parecidos, aunque de cronología muy diferente: 6.600 y 9.000 años BP respectivamente. Hay un hiato (o hiatos) deposicional importante entre los niveles 10 y 10.1. Este aspecto no fue reconocido durante el sondeo inicial hecho en la Cabaña. También hay diferencias en las asociaciones de pequeños mamíferos: en el nivel 10 hay Sorex minutus Linnaeus, 1766 y quirópteros que están ausentes en 10.1. La presencia del pequeño murciélago de cueva del nivel 10, Miniopterus schreibersii Kuhl, 1817, puede indicar que la cueva era temporalmente deshabitada por humanos entre los 5.690 y 5.570 años, ya que en general los murciélagos no cohabitan con los humanos (también podría ser un problema de muestreo dado el pequeño tamaño y la fragilidad de los restos óseos de los quirópteros). También es de notar la presencia de Arvicola sapidus Miller, 1908 en el nivel 10. Ésta sería la primera entrada holocena de la rata de agua ibérica en el norte de la península ibérica. Tres citas indi-

Tabla 2. Distribución estratigráfica de los pequeños mamíferos del Mirón. En la columna de la izquierda sólo están representados los niveles estratigráficos que contienen fósiles de pequeños mamíferos. Las dataciones de radiocarbón provienen de Straus \& González Morales (2003, 2007).

Stratigraphic distribution of the small mammals of El Mirón Cave. On the left column, there are only the stratigraphic levels with small mammal contents. The radiocarbon data are after Straus \& González Morales (2003, 2007). 


\begin{tabular}{|l|c|}
\hline Cultura & 14 C Ka B.P. \\
\hline Medieval & $1,1-1,4$ \\
\hline Bronce & $3,2-3,7$ \\
\hline Calcólítico & $3,7-4,1$ \\
\hline Neolítico & $4,7-5,8$ \\
\hline Mesolítico & $8,4-9,6$ \\
\hline Azilian & $9-11,5$ \\
\hline Magdaleniense Superior & $11,5-13$ \\
\hline Magdaleniense Inferior & $13-17$ \\
\hline Solutrense & $17-20$ \\
\hline Gravetiense & $20-28$ \\
\hline Auriñaciense Superior & $28-35$ \\
\hline Chatelperroniense & 35 \\
\hline Auriñaciense Inferior & $35-40$ \\
\hline Musteriense & $41-$ \\
\hline
\end{tabular}

Nivel 13: Arcilla amarillento-anaranjada con gravas y cantos que desaparecen hacia la base. Casi estéril en cuanto a contenido arqueológico, a excepción de algunos huesos y sílex, que podrían ser contaminación por percolación. En la base se encuentran cantos de gran tamaño con algunos sílex asociados.

Nivel 14: arcilla compacta y plástica, de color amarillentobeige, similar a la del nivel 13. Se diferencia de éste más por su contenido arqueológico, pues presenta una mayor concentración de sílex, que por su carácter sedimentológico. A pesar de que el número de muestras es relativamente elevado, tanto los niveles 13 y 14 siguen siendo pobres en cuanto al número de especies de pequeños mamíferos.

Nivel 15: arcilla semejante a la de los niveles 13 y 14, con mayor contenido en cantos angulosos. Es un nivel rico en elementos arqueológicos.

Nivel 16: arcilla prismática, arenosa, de color marrón oscuro, con cantos angulosos $(<5 \mathrm{~cm})$. Contiene artefactos, huesos triturados y cantos redondeados, de tamaño centimétrico.

Nivel 17: Limo gris-marrón con arena, cantos angulosos y algunos redondeados. Rico en sílex y utensilios de hueso; astas y abundantes huesos largos y cráneos de cabra montesa. Algunas áreas, de color más oscuro, presentan acumulaciones de cantos redondeados, muchos rotos y/o rubefactados a causa del fuego.

Tabla 3. Cronología en miles de años (Ka), datos de radiocarbon $\left(\mathrm{C}^{14} \mathrm{BP}\right)$ de los Niveles culturales del Paleolítico y Neolítico Europeos (Straus, 2005; este trabajo). Chronology in thousand of years $(\mathrm{Ka})$, radiocarbon data $\left(C^{14} B P\right)$ of the Cultural levels of the European Paleolithic and Neolithic (Straus, 2005; this work).

can la presencia de Arvicola sapidus en yacimientos cántabros del Pleistoceno superior: en los niveles Solutrenses de La Riera (Altuna, 1986) y Las Caldas así como en el Magdaleniense de Rascaño 7 (Pokines, 1998). También la encontramos en el Pleistoceno superior del Mirón, en el Magdaleniense inicial, nivel 17 (Tabla 2). Además de lo comentado sobre A. sapidus, en 10.1, es de notar la falta de Microtus arvalis (Pallas, 1779), Sorex Linnaeus, 1758, Crocidura Wagler, 1832 y los quirópteros Myotys Kaup, 1829 y Miniopterus Bonaparte, 1837. Además es el único nivel de toda la secuencia en el que se encuentra la ardilla común, Sciurus vulgaris Linnaeus, 1758. La ardilla es un habitante de bosque más o menos denso, y suele ser raro en los yacimientos ya que constituye una presa difícil para la mayoría de los predadores causantes de las acumulaciones. Así que este dato podría ser tomado como una presencia extraordinaria, ligada a la mayor continuidad lateral de este nivel, lo que supone un área de muestreo mayor. Desde el punto de vista arqueológico el nivel 10 carece de cerámica, pero tiene industria lítica y huesos (Straus \& González Morales, 2001a).

Conjunto 11: Arcilla arenosa de color anaranjado a marrón claro, con cantos angulosos medianos a gruesos $(>10-20 \mathrm{~cm})$. En el cuadro I3, por debajo del nivel 11, se diferencian los subniveles 11.1, de color gris oscuro, y 11.2, de color amarillento claro, arcilloso, con cantos. Hay una disminución de la diversidad de pequeños mamíferos con respecto a los niveles anteriores, y esta pobreza en el número de taxones se mantiene hasta el nivel 17.

Nivel 12: Arcilla de colores anaranjado y marrón-beige claro. Contiene cantos y gravas así como huesos, un arpón Magdaleniense, y artefactos líticos, especialmente a techo.

Zona de la Trinchera (Mid-Vestibule Trench). Cuadros R7, O-P/6 y continuación de N-K/5. Niveles 300 a 314 (Fig. 5)

La diversidad en pequeños mamíferos de esta zona de la Cueva del Mirón es menor que en las demás zonas, hecho probablemente relacionado con el menor número de muestras estudiado (Tabla 2). Es interesante notar que las especies minoritarias en las demás zonas (Arvicola sapidus, Microtus gregalis, lagomorfos, quirópteros, Mustela) están ausentes aquí. Los niveles 300 a 302 están alterados por remociones y/o excavaciones no arqueológicas en la cueva, previas a 1996. Por esto no analizamos los microvertebrados de estos niveles.

Nivel 300: nivel de relleno, con gravas, cantos angulosos y redondeados, de tamaños variados, en una matriz limosa, de color marrón oscuro rica en materia orgánica. Contiene madera y mezcla de artefactos de diferentes niveles culturales.

Nivel 301: También un nivel de mezcla. Limo marrón claro con cantos redondeados que rellena perforaciones recientes y con vidrio en algunos sitios.

Nivel 301.0: lentejón de arcilla amarillenta-beige de unos 2-3 $\mathrm{cm}$ de potencia.

Nivel 301.1: nivel de ceniza gris con lentejones de carbón en la base $(6-10 \mathrm{~cm})$.

Nivel 301.2: mezcla de arcilla amarillenta-beige a techo y ceniza gris con lentejones de carbón en la base. Se observa una perforación reciente.

Nivel 302: limo rojizo-marrón de aspecto granuloso por el contenido en arena, más compacto en algunas zonas. Hay también una zona de perforación y relleno.

Nivel 303: limo arcilloso amarillo beige (puede variar de 2 a $6 \mathrm{~cm}$ de grosor). También está localmente afectado por la perforación del nivel 302. Este es el primer nivel de la Trinchera en el que se estudian los pequeños mamíferos, ya que los anteriores podrían tener problemas de contaminación.

Nivel 303.1: nivel de relleno de un hogar bajo el nivel 303. Compuesto de ceniza y carbón de color gris y negro. Está perfo- 


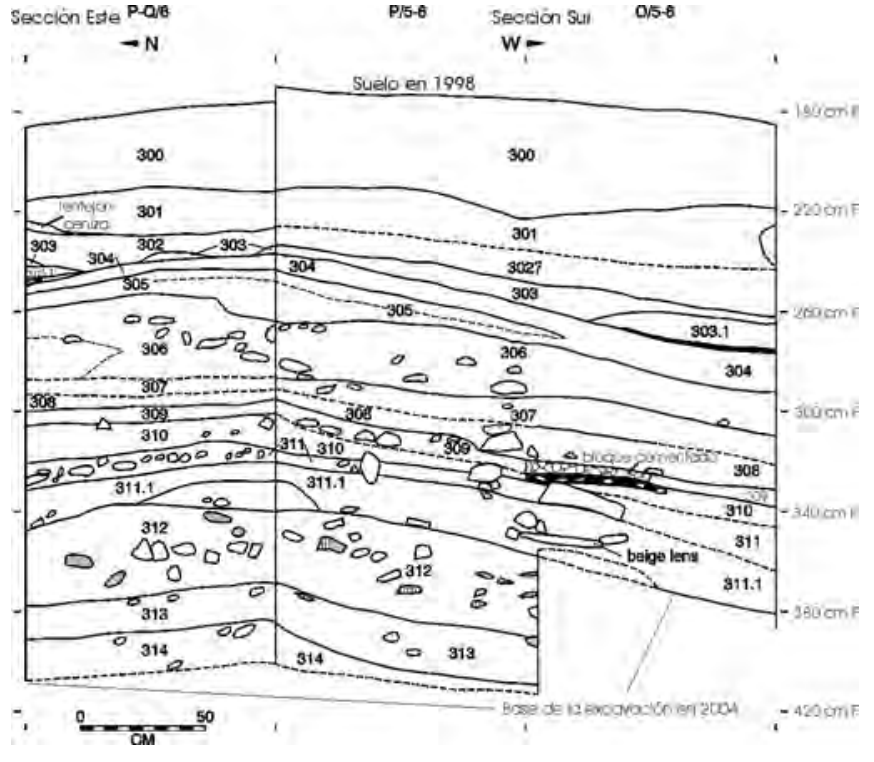

Figura 5. Estratigrafía de la Zona de la Trinchera. Los niveles están representados por los números dentro del esquema estratigráfico. Los números de la Columna de la derecha indican la profundidad de excavación en centímetros (cm P).

Stratigraphy of the Mid Vestibule or Trench Area. The levels are represented by the numbers inside the stratigraphic scheme. The numbers at the rigth column indicate the deepness of the excavation in $\mathrm{cm}$ (cm P).

rado localmente en los cuadros O6 y P6 por lo que el contenido de estos cuadros queda eliminado del estudio cuantitativo.

Nivel 303.2: arcilla amarillo-beige de 5 a $6 \mathrm{~cm}$ de potencia.

Nivel 303.3: lentejones de cenizas y carbón pareados o alternantes, de 2 a $10 \mathrm{~cm}$ de grosor. El nivel se hace más potente de este a oeste. Es el nivel más bajo con cerámica en la Zona de la Trinchera. Un dato interesante de este nivel es la presencia de trigo, lo que aporta evidencias directas de agricultura, al menos hace 5.550-5.790 B.P (Peña-Chocarro et al., 2005) en Cantabria. Aunque el nivel 303.3 carece de pequeños mamíferos, su presencia en niveles infra- y suprayacentes indica que la actividad agrícola, no debió de ser importante como para favorecer la introducción del ratón espiguero (Micromys minutus), presente en otras partes de la Península Ibérica desde el Pleistoceno (Agustí \& Galobart, 1986), pero ausente en la Cornisa Cantábrica durante el Pleistoceno y por lo menos hasta época Medieval (Pokines, 1998, este trabajo).

Nivel 304: Es un nivel formado por precipitado carbonatado blanco y pulverulento. Arqueológicamente pobre, pero el más rico en restos de pequeños mamíferos. Aunque es un nivel sin datación radiométrica, por la fauna podría ser equivalente al nivel 10 de la cabaña, en donde Apodemus Kaup, 1829 y Myoxus dominan numéricamente. Géneros típicos de frondosidad, su presencia indica un momento de expansión del bosque. También encontramos Crocidura, que aunque escasa, indicaría un clima más benigno.

Nivel 305: limo arenoso de color beige con lentejones rosado-anaranjado a gris-blanquecino, estos últimos con un alto contenido en carbonatos. Contiene pocas rocas pero se encuentran bastantes fragmentos de espeleotemas, especialmente en la zona de goteo activo del cuadro P6. Es arqueológicamente más rico que 304, con una atribución cultural al Aziliense (10.270 años BP). Ambos niveles 304 y 305 podrían estar en continuidad lateral con el nivel 10.1 de la Cabaña.

Nivel 306: limo arenoso oscuro marrón-gris, con artefactos de sílex, huesos, cantos redondeados y clastos, tanto redondeados como angulosos. En este nivel desaparecen las especies indicadoras de bosque como los lirones y ratones de campo o leonados, Apodemus); además es el único nivel de la Trinchera que tiene ambas especies de topillos de prado (Microtus agrestis Linnaeus, 1761 y M. arvalis). Arvicola terrestris es menos abundante que en los niveles superiores. Todo ello parece indicar unas condiciones más abiertas y frescas.

Zona del Corral (Vestibule Rear). Cuadros T-V/7-8; SQ/7. Niveles 99 a 119 (Fig. 6)

Los niveles 99 a 102 son estériles en pequeños mamíferos. En general también pobres en materiales arqueológicos y paleontológicos.

Nivel 99: Es un nivel actual, sin fauna, compuesto por limo suelto de color marrón rojizo claro, con cantos.

Nivel 100: también nivel reciente, con una mezcla de huesos, cantos y material de relleno de cabaña actual. Sin pequeños mamíferos.

Nivel 101: Limo gris marrón con cantos, gravilla fina y zonas encostradas por goteo que constituye la base de la superficie de relleno reciente.

Nivel 102: limo arenoso amarillo anaranjado, sin arcilla. Contiene restos dispersos de sílex y huesos.

Nivel 102.1: Lentejón fino de ceniza y carbón, que podría corresponder a un hogar. Es el primer nivel en el que encontramos pequeños vertebrados.

Nivel 102.2: Nivel arenoso, con más gravilla que el anterior, de color amarillo beige. Su potencia varía de 1 a $5 \mathrm{~cm} \mathrm{Li}$ geramente más rico en pequeños mamíferos que el nivel anterior. En casi todos los niveles del Corral, la asociación está dominada por la especie Arvicola terrestris (> 20\%) salvo en el nivel 108, en el que aumenta la biodiversidad y deja de ser el elemento mayoritario.

Nivel 103: limo arenoso gris marrón con lentejones rojizoamarillentos de arena granular. Contiene algo de sílex y huesos. Estéril en pequeños mamíferos.

Nivel 104: limo arcilloso, compacto, de color gris oscuro a marrón negruzco, con algo de grava. Contiene cantos angulosos de tamaño pequeño a medio. Contiene cenizas y materiales calcinados. Pobre en microfauna.

Nivel 105: limo arcilloso gris amarillento, con manchas de color marrón-beige y gris marrón, con algunas evidencias de procesos de crioturbación. Estéril en pequeños mamíferos.

Nivel 106: limo de un homogéneo color marrón oscuro, con algunos parches gris negruzco. Contiene huesos y sílex quemados. Grandes cantos angulosos y bloques. Es un nivel del Magdaleniense superior (equivalente al nivel 12 de la Cabaña y el 308 de la Trinchera) culturalmente rico, con huesos ennegrecidos. En este nivel se produce un incremento tanto en el número de especies como en el número mínimo de individuos. Este es el nivel del Corral en el que Microtus oeconomus (Pallas, 1776) aparece por última vez. Es notable que, a excepción del nivel 
130 de la Rampa, M. oeconomus esté presente en casi toda la secuencia del Mirón, donde desaparece en los niveles posteriores a los datados en 2.000 años BP. Por otra parte, el nivel 106 constituye el último registro de Pliomys lenki Heller, 1930 no sólo en la sección del Corral del Mirón, sino en toda la cueva. Éste sería además el dato más reciente para la extinción de la especie, puesto que las nuevas dataciones del Mirón, para este nivel 106, permiten fecharlo en 12.460 años BP.

Nivel 106.1: limo marrón claro con pequeños cantos, rodados y angulosos. Un hoyo con relleno posterior, atraviesa los niveles 105 a 107 . Hacia el sur hay madrigueras de tamaño variable. Dada una posible contaminación se ha preferido eliminar del análisis a los pequeños mamíferos de éste nivel.

Nivel 107: Limo compacto amarillo beige, deformado por caída de bloques.

Nivel 107.1: limo de color marrón claro, con fragmentos de rocas de cerca de $20 \mathrm{~cm}$ de diámetro. Todo el nivel constituye un relleno de madriguera, probablemente de lagomorfos, ampliada por la actividad de carnívoros de pequeño a mediano tamaño. Se encuentran restos arqueológicos y huesos (Fig. 6), y es pobre en pequeños mamíferos. Los niveles infra- y suprayacentes a 107.1 contienen, relativamente en relación con el resto de la secuencia, numerosos restos de pequeños carnívoros y lagomorfos (Marín Arroyo, 2007), lo que apoyaría la atribución de las madrigueras a su actividad biológica.

Nivel 107.2: limo gris verdoso, estéril. Está bioturbado por las madrigueras de 107.1. En el cuadro T10 el techo tiene una capa de ocre rojo.
Nivel 108: limo marrón oscuro a claro. Contiene cantos angulosos con evidencias de alteración (blancos). Como en 106 es rico en huesos y sílex y en algunas zonas está en contacto directo con este nivel, ya que el nivel 107 es discontinuo (Fig. 6). Aunque el color es variable, se hace más oscuro hacia la base. Contiene abundantes huesos ennegrecidos, sílex, algunos cantos redondeados con evidencias de haber sido quemados. A techo se encuentran numerosos bloques caídos. En pequeños mamíferos, el nivel 108 es el más rico de toda la secuencia del Corral y después del nivel 10 de la Cabaña, el más rico de la Cueva del Mirón. Como en 10, es el único nivel en el que se han encontrado restos fósiles del pequeño murciélago de cueva, $M i$ niopterus schreibersii. También es de notar la coincidencia en el gran número de individuos de Chionomys nivalis (Martins, 1842) en ambos niveles cuya edad y proporción del número mínimo de individuos de otras especies de pequeños mamíferos son, sin embargo distintas.

Nivel 109: limo de color marrón carente de clastos y huesos quemados. De carácter discontinuo. La diversidad de pequeños mamíferos es notablemente menor que en los niveles precedente y posterior.

Nivel 110: limo marrón negruzco y gris, rico en materia orgánica y huesos ennegrecidos, piedras y sílex. En contacto directo con 108 en las áreas donde 109 está ausente. Aquí aparece Pliomys lenki, el cual falta en niveles suprayacentes, hasta encontrarlo de nuevo en el nivel 106 como hemos señalado. La especie se encuentra también en niveles más antiguos de otras secciones (Tabla 2 y Fig. 9).

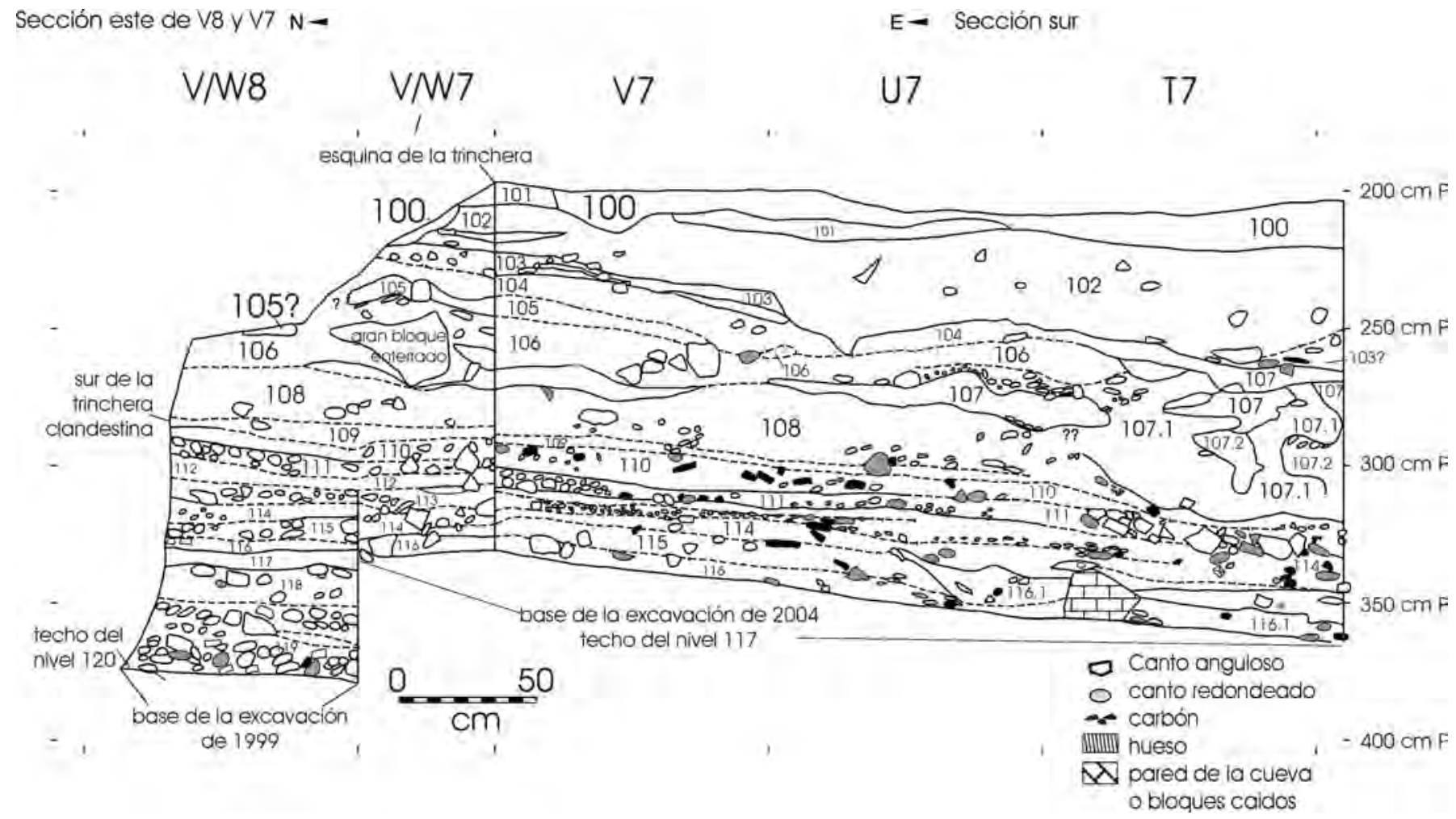

Figura 6. Estratigrafia de la Zona del Corral. Los niveles están representados por los números dentro del esquema estratigráfico. Los números de la Columna de la derecha indican la profundidad de excavación en centímetros (cm P). Stratigraphy of the Vestibule Rear area. The levels are represented by the numbers inside the stratigraphic scheme. The numbers at the rigth column indicate the deepness of the excavation in $\mathrm{cm}(\mathrm{cm} \mathrm{P})$. 
Nivel 111: limos de color marrón oscuro a negruzco. Rico en huesos ennegrecidos y sílex, como en 108 y en 110, pequeño a mediano tamaño. Contiene también cantos angulosos alterados, recubiertos de una sustancia blancuzca. Se distingue un lentejón con mayor cantidad de clastos aunque con matriz limosa; característica de este nivel y de los superiores. Su grosor varía entre 3 y $5 \mathrm{~cm}$.

Nivel 112: Limo marrón claro con menos cantos angulosos que en 111 pero rico en artefactos y fauna. Desde éste nivel hasta la base, el contenido en pequeños mamíferos y su diversidad disminuyen notablemente, con dos especies dominantes, Arvicola terrestris y Talpa europaea, sobre una empobrecida diversidad de arvicolinos e insectívoros; no se encuentran quirópteros ni lagomorfos y comadreja sólo en el nivel 113.

Nivel 113: nivel de gravas carbonatadas corroídas, alteradas y de color blanco. La matriz es un limo marrón oscuro con huesos pero poco sílex, con características del Magdaleniense inferior Cantábrico. El color presenta también alternancias claro-oscuro como en 111. Hay que señalar que es el único nivel de la zona del Corral, y de toda la secuencia del Mirón (Tabla 2) que tiene Microtus gregalis Pallas, 1779, una especie abundante en Francia durante el Pleistoceno superior, pero rara en la Península Ibérica, donde sólo se encuentra en otro yacimiento del Magdaleniense inferior Cantábrico: Erralla V, en Guipúzcoa (Pemán, 1985). La presencia de especies esteparias, procedentes del Norte y Este de Europa indicaría un momento frío durante la formación de este nivel.

Nivel 114: limo de color marrón claro con cantos, aunque en menor cantidad que en el nivel 113.

Nivel 115: limo marrón negruzco a gris claro con grandes cantos angulosos de caliza corroídos y alterados de color blanquecino.

Nivel 116: limo marrón negruzco a gris, con cantos redondeados y esquirlas de cantos, huesos ennegrecidos e industria en sílex. Menos cantos angulosos que en 115. Éste es el nivel con la menor diversidad en pequeños mamíferos de la secuencia, y a partir de aquí, hacia la base, desaparecen.

Nivel 117: limo de color claro a marrón gris con grandes bloques caídos de color blanco. El nivel presenta abundantes evidencias de fuegos, como algunos huesos calcinados, carbón $\mathrm{y}$ piedras quemadas.

Nivel 118: limo arcilloso y compacto de color marrón claro con gravas y pequeños fragmentos de caliza dispersos. Abundantes huesos. Sin bloques caídos.

Nivel 119: limo arcilloso marrón anaranjado con una capa masiva de bloques caídos redondeados y alterados de color blanco. Abundantes huesos.

Zona de la Rampa distal de la terraza aluvial (Alluvial Terrace Footslope). Cuadros X-W/10. Niveles 120130 (Fig. 7)

Se introduce la nomenclatura de excavación, poniendo entre paréntesis los niveles "400" que se utilizaron originalmente en la excavación para separar los niveles de los distintos sectores de la cueva, antes de establecer la equivalencia del nivel 120 con el nivel 400. En la excavación del Sondeo de la Rampa se ha llegado al nivel más antiguo de la Cueva del Mirón, el 130, datado en 41.280 años. El sondeo tiene $2 \mathrm{~m}^{2}$ (cuadros X-W10) excavado desde el fondo de un gran pozo de excavaciones clandestinas al pie de la rampa que sube hacia el interior oscuro de la cueva

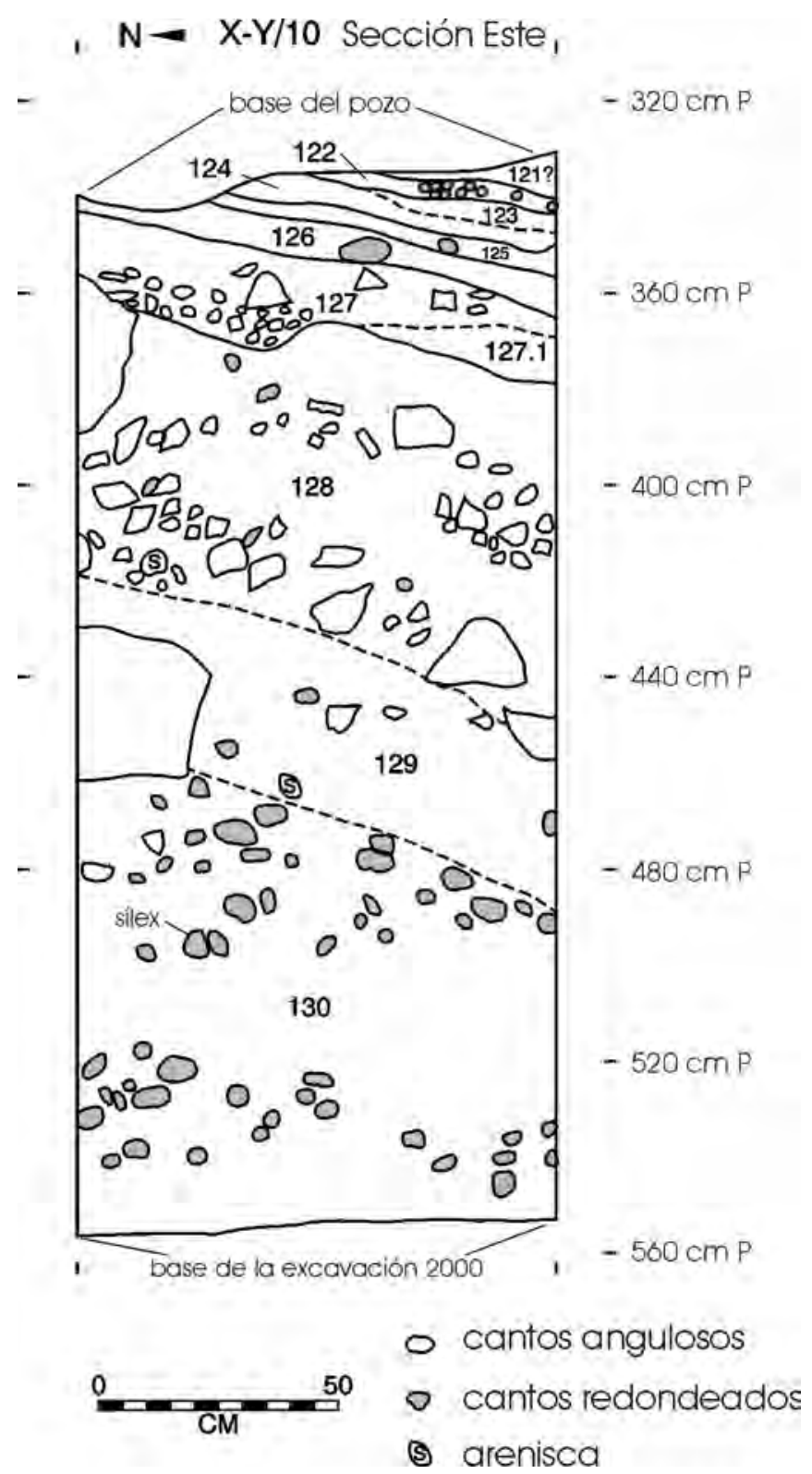

Figura 7. Estratigrafia de la Zona del Sondeo de la Rampa. Los niveles están representados por los números dentro del esquema estratigráfico. Los números de la Columna de la derecha indican la profundidad de excavación en centímetros (cm P).

Stratigraphy of the Sondage of the Foot slope area. The levels are represented by the numbers inside the stratigraphic scheme. The numbers at the rigth column indicate the deepness of the excavation in $\mathrm{cm}$ (cm P).

(Fig. 3). Ni la diversidad específica ni la abundancia (en términos de número mínimo de individuos) son las mas altas de la secuencia, aunque ambos parámetros aumentan notablemente en los niveles más antiguos (128-130). Es de notar que las especies de bosque son inexistentes en esta zona, a excepción de un único individuo de Apodemus en el nivel 128. Aunque hay todavía que esperar las muestras procedentes de las próximas excavaciones, 
es posible que esta ausencia esté ligada a las condiciones climáticas que caracterizan el Ultimo Máximo Glaciar. El número de muestras estudiadas hasta el momento en esta zona es pequeño en comparación con el resto de los sectores (Tabla 2).

Nivel 120 (=400): arcilla limosa moteada amarillo-beige, con abundantes fragmentos de rocas y cantos redondeados, situada por debajo de un pozo de unos $12 \mathrm{~cm}$. En W10 un nivel de cantos pequeños podría también ser un relleno. No se encuentran cerámica ni artefactos "modernos" en 120 a pesar de estar justo por debajo del "pozo clandestino".

Nivel 121 (=400.1): limo marrón con fragmentos de roca, materia orgánica e industrias líticas.

Nivel 122 (=401): limo arcilloso, amarillo-beige, homogéneo, compacto con fragmentos de roca, grava y cantos redondeados. Algo de sílex y huesos.

Nivel 123 (=401.1): nivel lenticular fino, limoso marrón, con fragmentos de rocas. Pasa lateralmente al 122 en el cuadro W10. Contiene huesos y sílex en forma de puntas Solutrenses.

Nivel 124 (=401.2): nivel limoso marrón, con clastos de rocas y arena, bajo 123, que pasa lateralmente a 122 en el cuadro W10. Es arqueológicamente estéril.

Nivel 125 (=402): limo marrón oscuro con sílex (puntas Solutrenses) y huesos, de 10 a $12 \mathrm{~cm}$.

Nivel 126 (=403): limo arcilloso-arenoso de color beige, con cantos redondeados y angulosos. Contiene numerosos huesos, artefactos líticos (puntas Solutrenses) y óseos (caninos y astas de ciervo perforados).

Nivel 127 (=404): capa de color oscuro, marrón grisáceo, con fragmentos de rocas, grandes lascas y otros artefactos y abundantes restos de grandes mamíferos (cabra montesa) representados por huesos y dientes aislados.

Nivel 128 (=405): limo arcilloso amarillo brillante, compacto y liso, que presenta un contacto neto con el nivel 127. La base contiene más fragmentos de roca y es más gris que el techo. Contiene algunas lascas de sílex. Rico en restos óseos.

Nivel 129 (=406): es un nivel que presenta un paso lateral, hacia la base, del nivel 128. Es una arcilla maleable de color amarillo brillante y algo limosa. Se encuentra rodeando grandes bloques de caliza.

Nivel 130: pasa lateralmente al nivel 129, se distingue de éste por ser más limoso y con un color más rojizo. Contiene numerosos cantos rodados de diverso tamaño. Se encuentra por debajo de los grandes bloques de caliza. Contiene lascas, dos denticulados, huesos y carbón disperso. Es el único nivel de toda la secuencia del Mirón en el que se han encontrado restos del topo de río, Galemys pyrenaicus (E. Geoffroy, 1811). Es el nivel más antiguo del presente análisis.

\section{LOS PEQUEÑOS MAMÍFEROS DE LA CUEVA DEL MIRÓN}

La mayoría de los pequeños mamíferos del Pleistoceno tardío y Holoceno del Mirón se hallan entre la fauna actual de la Cornisa Cantábrica a excepción de Pliomys lenki, Microtus oeconomus y M. gregalis (Tabla 1). En la actualidad hay 47 especies de pequeños mamíferos en Asturias, Cantabria y País Vasco (Cornisa Cantábrica a partir de ahora) incluyendo los cinco órdenes mencionados, aunque de los carnívoros sólo tenemos en cuenta a los pequeños mustélidos (comadrejas, martas y visones). Los datos de la fauna actual tienen varias fuentes: el Atlas de los Mamíferos Terrestres de España (Palomo \& Gisbert, 2002), el estudio de las egagrópilas de lechuza común o de campanario (Pokines, 1998) y observaciones de otros autores (Iza et al., 1985; Galán, 1997; Blanco, 1998 a, b). Según estos datos, las especies de pequeños mamíferos que habitan hoy en la Cornisa Cantábrica varían según la región, pero en total no llegan a la treintena (Tabla 1). Esto implica que si contamos a los quirópteros, las especies del Mirón representan un 57\% de la fauna actual; pero si los descontamos, ya que por su fragilidad seguramente están infravalorados en el registro fósil con respecto a los muestreos y análisis actuales, entonces la fauna del Mirón representa el $86 \%$ de la fauna de pequeños mamíferos actuales de la Cornisa Cantábrica, sin descontar la fauna introducida recientemente por el hombre (Rattus, Mus y Muscardinus).

\section{MATERIALES, METODOLOGÍA, NOMENCLATURA}

Para la obtención de pequeños fósiles se han utilizado tamices de luz de malla de $2 \mathrm{~cm}$ el mayor y de 1 a $2 \mathrm{~mm}$ el menor. La recuperación de estos fósiles no sería posible si se utilizan tamices de luz de malla más grandes ya que la mayoría de los restos de musarañas, musgaños y murciélagos (Soricomorpha y Chiroptera) son de menor talla, por lo que la representación de estos órdenes así como la de los roedores más pequeños $(\mathrm{Mu}-$ rinae) estaría bastante sesgada. Para conocer el significado del posible sesgo hemos comparado con trabajos de otros autores (Pokines, 1998; Zubeldia Garmendia, 2006).

Una vez separados los microfósiles del sedimento ya lavado, se vuelven a lavar en una cubeta de ultrasonidos para eliminar las partículas de matriz más fina. Posteriormente, para su estudio, se montan los elementos diagnósticos en soportes diversos y se archivan en pequeñas cajas de plástico transparente, etiquetadas con la sigla completa de la muestra, que consta de los siguientes datos: Yacimiento El Mirón, fecha de campaña, $n^{\circ}$ de muestra, cuadro, sector, nivel estratigráfico (ver Figs. 4-7) y tramo (el tramo, spit, es una unidad menor, de escala centimétrica, lo que implica que el muestreo de los pequeños mamíferos del Mirón es prácticamente continuo pues se hace cada centímetro o cada pocos centímetros, Figs. 4-7). Gracias a la excavación arqueológica de la Cueva del Mirón se ha podido obtener una de las más importantes secuencias de fósiles de pequeños mamíferos del Holoceno y finales del Pleistoceno superior cántabro (Tabla 2).

La identificación de cada especie se basa en elementos diagnósticos, craneales y postcraneales, del esqueleto de estos pequeños vertebrados (Figs. 8, 9, 10, 11): en general el número mínimo de individuos (NMI) se calcula a partir del número de primeros molares inferiores en el caso de los arvicolinos, un molar diagnóstico en el resto de los pequeños mamíferos o un elemento postcraneal igualmente determinable; además se tiene en cuenta la simetría bilateral del esqueleto de los vertebrados. En El Mirón se han estudiado hasta el momento 721 muestras, 
con un total de 3.403 NMI. Otros 100.000 restos óseos de pequeños mamíferos, aves, anfibios, reptiles y peces están todavía por identificar.

La metodología utilizada es la bioestratigráfica, es decir el análisis tanto cualitativo cómo cuantitativo de la distribución de las especies por niveles y tramos o tallas en las secuencias estratigráficas de las distintas zonas. Un estudio tafonómico preliminar de los microvertebrados del Mirón indica que éstos son el producto de la acumulación de egagrópilas producidas por rapaces nocturnas principalmente (ya que la mayoría de los restos, aunque rotos, presentan un moderado estado de digestión y constituyen una buena representación del esqueleto completo), con algún aporte ocasional por parte de pequeños carnívoros como la comadreja, Mustela nivalis Linnaeus, 1766, que está presente en casi toda la secuencia (Tabla 2), el gato silvestre Felis sylvestris Schreber, 1775 y el zorro, Vulpes vulpes Linnaeus, 1758; los cuales se alimentan de pequeños mamíferos (Carvalho \& Gomes, 2004; Hernández, 2005) y podrían utilizar la cueva eventualmente como refugio y/o comedero. Como se ha comentado en el apartado de Estratigrafía, un ejemplo de utilización del Mirón por parte de los carnívoros son los niveles 107 a 107.2 del Corral. Otro factor de acumulación sería entradas ocasionales; éste podría ser el caso del topo común, cuyos restos suelen estar mejor conservados que los de otros pequeños mamíferos, aunque esto puede estar también ligado a la robustez del esqueleto postcraneal de este pequeño mamífero excavador. Por otra parte, según la propuesta de Eastham (1995), el topo habría podido ser cazado por el hombre por su piel.

La ausencia de restos de pequeños mamíferos en determinados niveles podría ser debida a la menor ocupación de los mismos por parte de las rapaces, hecho controlado por otros factores, climáticos o posiblemente la presión de la presencia humana. En los niveles actuales sí parece haber una relación directa entre el empobrecimiento general de la fauna debido a las actividades humanas, que trae como consecuencia una considerable disminución de hábitats favorables, agravándose con la introducción de predadores nuevos, así como la eliminación, por parte también del hombre, de las aves rapaces, las cuales son las principales generadoras de acumulaciones de pequeños mamíferos en las cuevas. El estudio de egagrópilas de rapaces actuales muestra que, en las zonas humanizadas, la diversidad disminuye con respecto a zonas con menor impacto humano (Brunet-Lecomte \& Delibes, 1984; observaciones personales).

El análisis bioestratigráfico se realiza en dos fases, en la primera se analiza la secuencia estratigráfica de cada zona para analizar la distribución tanto temporal como espacial. En la segunda fase hemos reunido las muestras correspondientes a cada zona en una única secuencia, estudiando tanto los cambios estratigráficos como, en los casos en que se discute, por niveles culturales (Tabla 3) para detectar posibles cambios relacionados con la actividad humana.

\section{SISTEMÁTICA}

La nomenclatura sistemática sigue la propuesta por García Perea \& Gisbert (1997) y Wilson \& Reeder (2005). En la descripción de los dientes de las distintas familias de pequeños mamíferos utilizaremos la nomenclatura establecida por diferentes autores (ver descripción más adelante). Se utilizarán las siglas: I para los incisivos, $\mathrm{C}$ caninos, $\mathrm{P}$ premolares y $\mathrm{M}$ los molares. Una letra mayúscula indica que el elemento dental es superior y una minúscula, inferior. La colección de microfósiles del Mirón (MIR 1-130, 300-306, Tabla 2) se conserva provisionalmente en el Área de Paleontología del Departamento de Ciencias de la Tierra de la Universidad de Zaragoza.

En este apartado también se incluye una breve síntesis sobre el hábitat, distribución geográfica y estratigráfica de cada especie, en comparación con el resto de la Península Ibérica y Europa. Hay que señalar que las especies de pequeños mamíferos del Mirón difieren sobre todo en las proporciones numéricas con respecto a otros yacimientos de la Cornisa Cantábrica, a excepción de la persistencia de Pliomys lenki (nivel 106, alrededor de 12.000 años) con respecto a otros yacimientos Ibéricos (Pokines, 1998; Arrizabalaga et al., 2003; Baena et al., 2005; Zubeldia Garmendia, 2006; éste trabajo). Las diferencias con yacimientos franceses cercanos del Pirineo oriental y la Gascogne son mayores, siendo de notar la rareza de los roedores arvicolinos Arvicola sapidus, Pliomys lenki y Chionomys nivalis en los yacimientos del Pleistoceno superior de Francia (Chaline, 1972; Marquet, 1989; Eastham, 1995).

También es notable el contraste con las asociaciones faunísticas de otros yacimientos del final del Cuaternario de la Península Ibérica (Sesé \& Sevilla, 1996; López-García, 2006), especialmente la ausencia de especies mediterráneas como el microtino ibérico Iberomys cabrerae (Thomas, 1906), y los insectívoros Atelerix algirus (Lereboullet, 1842), Neomys anomalus Cabrera, 1907, o Talpa occidentalis Cabrera, 1907, entre otras, en la Cornisa Cantábrica.

Los murciélagos (O. Chiroptera) son escasos. Sólo aparecen una especie de gran tamaño del género Myotis y otra de pequeño tamaño, Miniopterus schreibersii. Es notable la ausencia de Rhinolophus Lacépède, 1779, género generalmente representado por una o más especies en otros yacimientos de Cantabria como Covalejos (Sesé, 2005). La rareza de murciélagos, en general en la Cornisa Cantábrica (Pokines, 1998; Pemán, 2000; Baena et al., 2005; Zubeldia Garmendia, 2006; éste trabajo), contrasta con la riqueza en yacimientos del Sur de Francia como L'Hortus (Jullien, 1972).

Los pequeños carnívoros, en su mayoría de la Familia Mustelidae, se encuentran en El Mirón representados por la comadreja, Mustela nivalis, especie común en la Península Ibérica (Palomo \& Gisbert, 2002) y en general en los yacimientos Pleistocenos. Otros carnívoros de mayor talla los estudia Marín Arroyo (2007).

Las especies de roedores, a excepción de Pliomys lenki, viven en Europa en la actualidad. M. gregalis y M. oeco- 
nomus migraron hacia el norte de Europa, desapareciendo de la Península Ibérica en el Pleistoceno superior y en el Holoceno respectivamente (Pokines, 1998; este trabajo). La especie Chionomys nivalis se encuentra en la región pero sólo en la alta montaña, entre 1.500 y $2.000 \mathrm{~m}$ de altitud (Palomo \& Gisbert, 2002).

Los lagomorfos, representados en El Mirón, consisten fundamentalmente en dientes aislados de Lepus y Oryctolagus (Marín Arroyo, 2007; este trabajo).

Orden ERINACEOMORPHA Gregory, 1910

Familia Erinaceidae Fischer von Waldheim, 1817 Género Erinaceus Linnaeus, 1758

\section{Erinaceus europaeus Linnaeus, 1758}

El erizo europeo es escasísimo en El Mirón, un único resto es asignable a esta especie en el nivel 7 (Tablas 1 y 2). Por esta razón no vamos a dar más detalles sobre esta especie pues desconocemos su significado estratigráfico o ecológico en las asociaciones de pequeños mamíferos del Mirón.

Orden SORICOMORPHA Gregory, 1910

Familia Soricidae Fischer von Waldheim, 1817 Género Sorex Linnaeus, 1758

\section{Sorex gr. S. coronatus Millet, 1758 -} S. araneus Linnaeus, 1758

Fig. 8.a-8.b

Las especies del género Sorex son difíciles de distinguir basándonos en caracteres craneales, especialmente cuando sólo contamos con dientes aislados o mandíbulas sin dientes (Brunet-Lecomte \& Delibes, 1984; Casteig \& Escala, 1988; López-Fuster \& Ventura, 1996). Los restos de Sorex del Mirón son escasos y fragmentarios por lo que no es posible hacer este análisis, aunque podemos distinguir una forma algo más robusta de otra que es algo más grácil. Los sorícidos se distinguen por tener el cóndilo articular desdoblado, con dos facetas articulares separadas por la zona interarticular que puede variar en longitud (dorso-ventral) y en anchura (latero-medial). Las especies de Sorex se distinguen de las de Crocidura por tener los dientes rojos y el cóndilo articular grácil (más largo que ancho, Fig. 8). Por su distribución geográfica parece probable que la especie del Mirón sea Sorex gr. coronatus-araneus. La especie $S$. coronatus se encuentra desde el Pleistoceno superior y en la actualidad en la zona de Ramales de la Victoria y en toda la región Cántabra (Pokines, 1998). La especie S. araneus es una especie gemela, supuestamente no-simpátrica en la Península Ibérica con $S$. coronatus, aunque sí más al este en Europa (Pokines, 1998). Sin embargo algunos autores (Pemán, 1990b; Zubeldia Garmendia, 2006) proponen una
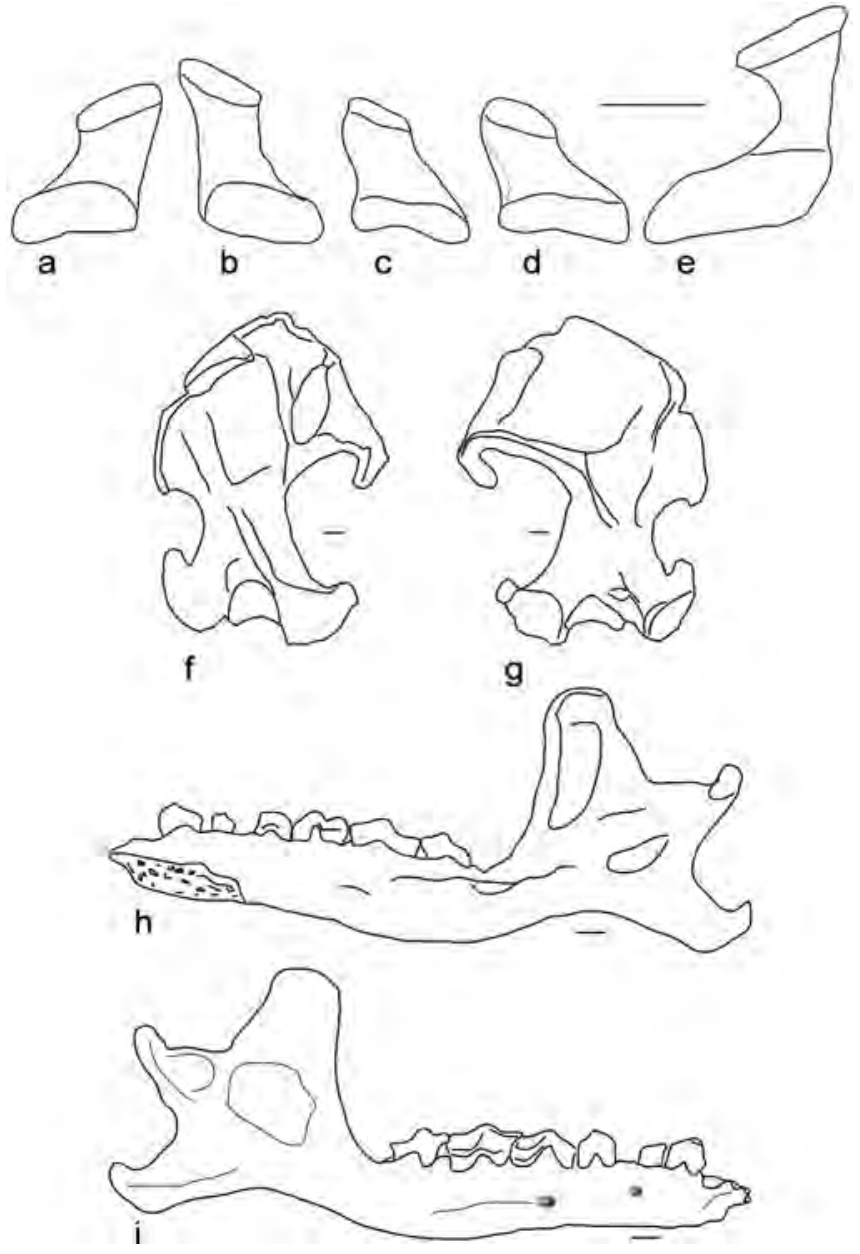

Figura 8. Los Insectívoros (Soricomorpha) Cuaternarios de la Cueva del Mirón, Ramales de la Victoria, Cantabria. a-e: Cóndilos articulares de diferentes especies del nivel 10 (MIR10); a: Sorex coronatus Millet, 1758-S. araneus Linnaeus, 1758 derecho; b: idem, izquierdo; c-d: Crocidura russula (Hermann, 1780) izquierdo; e: Neomys fodiens (Pennant, 1771) derecho; f-g: húmero derecho de Talpa europaea Linnaeus, 1758 del nivel 1, vistas posterior (f) y anterior (g); h-i: mandíbula derecha de Talpa europea Linnaeus, 1758 del nivel 10, vistas medial (h) y lateral (i). Dibujos con cámara clara. Las escalas representan $1 \mathrm{~mm}$.

Insectivores (Soricomorpha) of the Quaternary of the El Mirón Cave, Ramales de la Victoria, Cantabria, Spain. a-e: Articular condyles of different species of level 10; $\boldsymbol{a}$ : Sorex coronatus Millet, 1758-S. araneus Linnaeus, 1758 right; $\boldsymbol{b}$ : idem, left; $\boldsymbol{c}$-d: Crocidura russula (Hermann, 1780) left; $\boldsymbol{e}$ : Neomys fodiens (Pennant, 1771) right; $f$-g: right humerus of Talpa europaea Linnaeus, 1758 from level 1 , posterior $(\boldsymbol{f})$ and anterior (g) views; $\boldsymbol{h}$-i: rigth mandible of Talpa europea Linnaeus, 1758 from level 10, medial $(\boldsymbol{h})$ and lateral $(\boldsymbol{i})$ views. Light camera drawings. Bars represents $1 \mathrm{~mm}$.

zona de intersección, en el norte de la Península Ibérica (López Fuster et al., 1999). 
Hábitat y distribución geográfica: tres especies de Sorex se encuentran en el norte de la Península: la zona de intersección entre la musaraña común $S$. araneus y $S$. coronatus es una banda que se extiende al norte, en los Pirineos, aunque ésta última se extiende hasta Galicia y hacia el sur por el Sistema Ibérico. La musaraña ibérica se encuentra en el Sistema Central hasta la desembocadura del Tajo y de allí a Galicia (López-Fuster \& Ventura, 1996; LópezFuster et al., 1999). Son especies que habitan en lugares húmedos con una buena cobertera vegetal herbácea (prados húmedos para $S$. coronatus) o arbustiva e incluso arbórea (Pokines, 1998).

Distribución estratigráfica: $S$. araneus aparece en el Pleistoceno inferior de Europa (Maul, 1990). S. coronatus en el Pleistoceno superior (Pokines, 1998).

\section{Sorex minutus Linnaeus, 1766}

Es la musaraña de dientes rojos más pequeña del género Sorex. Su diminuto tamaño y la coloración de las cúspides, la hace fácilmente distinguible de otras especies de musaraña.

Hábitat y distribución geográfica: Ocupa la Europa templada, y en España el norte, entrando por la Cuenca del Duero, hasta Portugal (Blanco, 1998 a). Su presencia está ligada a una buena cobertera vegetal, preferentemente herbácea, en medios húmedos y templados.

Distribución estratigráfica: Sorex minutus se conoce desde el Pleistoceno inferior en toda Europa (Furió Bruno, 2003).

Género Neomys Kaup, 1829

\section{Neomys fodiens (Pennant, 1771)}

Fig. 8.e

El musgaño acuático, Neomys fodiens, es el sorícido actual de mayor tamaño de Europa. Habita en las proximidades de los cursos de agua. Como las especies de Sorex, tiene los dientes rojos. Se distingue claramente del resto de sorícidos por su cóndilo articular con faceta interarticular más alargada y estrecha, faceta ventral alargada hacia la cara medial y sus robustos dientes, propios de consumidor de pequeños invertebrados con concha o caparazón. En España hay dos especies de musgaños: $N$. fodiens o musgaño patiblanco y $N$. anomalus o musgaño de Cabrera. La especie $N$. fodiens es de mayor talla. Los restos de El Mirón se asignan a la especie $N$. fodiens por su gran talla, la altura coronoides es de 6 mm (Pemán, 1983).

Hábitat y distribución geográfica: En la actualidad Neomys fodiens se encuentra ampliamente repartido por
Europa y norte de la Península Ibérica mientras que Neomys anomalus tiene una distribución ligada a macizos montañosos de la Península Ibérica y centro-este de Europa. Están siempre ligados a masas de agua, arroyos o lagos pues se alimenta de invertebrados acuáticos. $N$. anomalus parece estar menos ligada al medio acuático que $N$. fodiens; se encuentra en prados y bosques húmedos (Blanco, 1998 a).

Distribución estratigráfica: Neomys fodiens se conoce al menos desde el Pleistoceno medio en Europa occidental (Jammot, 1974).

Género Crocidura Wagler, 1832

\section{Crocidura russula (Hermann, 1780)}

Fig. 8.c-8.d

La musaraña de dientes blancos es escasa en El Mirón, hay fragmentos de mandíbula, en las que se conserva bien el cóndilo, y fragmentos de cráneo. En uno de los maxilares se observa que el protocono de P3 está formando el borde antero-lingual del diente y en la base de la corona, en vista labial, el borde anterior es anguloso. Estas características permiten asignar este material a la especie C. russula.

Hábitat y distribución geográfica: Las especies del género Crocidura en la Península Ibérica son C. suaveolens, septentrional y atlántica, y $C$. russula, de amplia distribución en todo tipo de hábitats, incluso en medios humanizados (Blanco, 1998 a; Rey \& Landín, 1973).

Distribución estratigráfica: De la distribución estratigráfica de Crocidura en El Mirón se desprende que es rara (Tabla 2, Fig. 12), falta en la mayoría de los niveles Holocenos, y cuando se encuentra, es escasa. En el Pleistoceno es prácticamente inexistente salvo al final, ya prácticamente en el tránsito Pleistoceno-Holoceno. En Europa Crocidura russula se conoce desde el Pleistoceno inferior (Rzebik-Kowalska, 1998).

Familia Talpidae Fischer von Waldheim, 1817 Género Galemys Kaup, 1829

\section{Galemys pyrenaicus (E. Geoffroy, 1811)}

Como se ha comentado en la estratigrafía, un húmero del desmán del pirineo o topo de río es el único registro fósil de esta especie en El Mirón (Rampa, Nivel 130). Superficialmente se asemeja al húmero de las especies del género Talpa Linnaeus, 1758, del que se distingue, entre otros caracteres, por la menor anchura latero medial de su extremidad distal. 
Hábitat y distribución geográfica: El desmán ibérico o topo de río es un animal que vive en la proximidad de corrientes de aguas limpias, sin contaminar, de los ríos del Pirineo (Español y Francés, donde fue definida la especie), y de zonas montañosas en el resto de España y Portugal en la actualidad (Peyre, 1956; Alegre \& Hernández, 1990; Castién \& Gosálbez, 1992).

Distribución estratigráfica: El género Galemys se separa del género Desman desde el Plioceno (Rzebik-Kowalska, 1994). En la Península Ibérica se encuentra desde el Pleistoceno Inferior (López Antoñanzas \& Cuenca-Bescós, 2002; Furió Bruno, 2003). La especie Galemys pyrenaicus es un endemismo Ibérico que se cita desde el Pleistoceno Medio en Portugal (Marks et al., 2002) aunque es más común desde el Pleistoceno Superior (Pokines, 1998). La única cita de esta especie en el Cuaternario Francés es la de Jeannet et al. (1996).

Género Talpa Linnaeus, 1758

\section{Talpa europaea Linnaeus, 1758} Fig. 8.f-8.i

Los topos son animales cavadores, que se caracterizan por el robusto miembro anterior y por tener las mandíbulas alargadas con las apófisis angular y coronoide robustas que contrastan con su delicado cóndilo articular, simple y cilíndrico (Fig. 8h, i). Esta estructura es muy distinta de la de otros insectívoros como los sorícidos. Los restos de Talpa del Mirón pertenecen a una especie de gran talla y aunque la dentición y restos craneales de individuos adultos son escasos, por su robustez pensamos que son asignables a la especie Talpa europaea. Hay que señalar, sin embargo, que en algunos yacimientos de la Cornisa Cantábrica, como el Magdaleniense de Rascaño 5, 3 y Altamira o el Auriñaciense de Cueto de la Mina 7 (Pokines, 1998) se cita Talpa occidentalis. Como esta especie es escasa y difícil de distinguir de T. europaea si se carece de un estudio morfométrico detallado, de momento asignamos nuestra especie del Mirón a la especie más común y robusta, T. europaea como hemos indicado.

Hábitat y distribución geográfica: las especies del género Talpa son pequeños mamíferos de vida hipogea que necesitan suelos profundos para excavar las galerías en las que habitan. Son prácticamente ciegos y rara vez salen de sus madrigueras excepto en la época de reproducción. Autores como Eastham (1995) proponen que los hombres del Magdaleniense podrían haber cazado topos para aprovechar sus pieles en Dufaure. En el caso del Mirón es necesario un estudio tafonómico más detallado de los restos, tanto craneales como postcraneales para conocer cuáles son las causas de su presencia en la cueva, ya que en general, son difíciles presas de los predadores habituales, causan- tes de la acumulación de otros pequeños vertebrados. Sin embargo hay autores que lo citan, aunque como elementos raros, en las egagrópilas de Tito alba (Alegre et al., 1989; Campos Marcos et al., 2003).

Distribución estratigráfica: la especie Talpa europaea se encuentra desde el Pleistoceno inferior, tanto en Europa (Maul, 1990; Paunovic \& Rabeder, 1996) como en la Península Ibérica (Rofes \& Cuenca-Bescós, 2006).

\section{Orden CHIROPTERA Blumenbach, 1779}

Los restos de quirópteros son escasos en El Mirón, aunque esta escasez puede ser consecuencia del muestreo y la fragilidad de los huesos. Dada su rareza mencionaremos únicamente que los restos de gran tamaño son atribuibles a una de las especies del género Myotis Kaup, 1829 y los de menor tamaño a la especie Miniopterus schreibersii (Kuhl, 1817). Sobre la especie de mayor tamaño no podemos comentar mucho pero de la segunda podemos decir que es el representante más pequeño de los murciélagos de cueva europeos. Se encuentra generalmente en yacimientos cársticos desde el Pleistoceno inferior de Europa (Kowalski, 1956; Horacek, 1976; Sevilla García, 1988; Maul, 1990).

$$
\begin{aligned}
& \text { Orden CARNIVORA Bowdich, } 1779 \\
& \text { Género Mustela Linnaeus, } 1758
\end{aligned}
$$

\section{Mustela nivalis Linnaeus, 1766}

Los pequeños carnívoros son escasos en El Mirón aunque se encuentran en casi toda la secuencia. Los restos encontrados, por su tamaño y morfología, son asignables a Mustela nivalis, la comadreja.

Distribución estratigráfica: las comadrejas se conocen desde el Pleistoceno medio en Europa (Maul, 1990) y en España desde el Pleistoceno medio (García García, 2003).

Orden RODENTIA Griffith, 1827

Familia Sciuridae Hemprich, 1820

Género Sciurus Linnaeus, 1758

\section{Sciurus vulgaris Linnaeus, 1758}

La ardilla común Europea o ardilla roja, está representada por un único resto como se ha comentado en la estratigrafía (Cabaña, Nivel 10.1, Fig. 4 y Tablas 1 y 2). El resto fósil es un incisivo característico de esta especie por su intenso color rojo-anaranjado y sus acanaladuras labiales. Dado lo escaso de estos restos no vamos a comentar más de lo que ya se ha dicho en el apartado de estratigrafía. 
Familia Muridae Illiger, 1815

\section{Subfamilia Arvicolinae Gray, 1821}

Los arvicolinos, subfamilia que incluye a topillos, neverones y ratas de agua, son pequeños roedores de hábitos generalmente cavadores, que habitan en medios abiertos con suelos profundos en los que excavan sus madrigueras. Su distribución actual es holárctica, con escasas excepciones. La sistemática paleontológica de los arvicolinos está basada en la morfología y biometría de los dientes yugales (molares) que se caracterizan por su hipsodoncia o corona alta, que en la mayoría de las especies actuales alcanza la hipselodoncia (perdida de raíces con la ontogenia). Parámetros obtenidos en el análisis morfométrico de la dentición como el tamaño y la morfología oclusal (longitud mesio-distal, anchura, desarrollo de los triángulos labiales y linguales y de los complejos anterior o mesial y posterior o distal), altura de la corona, presencia/ausencia de raíces, presencia/ausencia de cemento en los entrantes, grosor del esmalte y el número de entrantes y salientes (también llamados triángulos por su morfología: triángulos de dentina rodeados por una pared de esmalte que puede cerrarlos por completo o casi cuando son confluyentes) en la superficie oclusal son los principales distintivos de un arvicolino. Las hipótesis filogenéticas o relaciones de parentesco y por lo tanto su clasificación están basadas en la evolución de estos caracteres (Chaline, 1972; van der Meulen, 1973; Brunet-Lecomte et al., 1987; Brunet-Lecomte \& Chaline, 1990; Rekovets \& Nadachowski, 1995; Maul \& Markova, 2007). El incremento de los estudios genéticos es una nueva fuente de información sobre las relaciones filogenéticas de los arvicolinos por lo que su posición dentro del orden Rodentia hace que muchas de las hipótesis filogenéticas "tradicionales" estén en continua discusión (Conroy \& Cook, 2000; Jaarola et al., 2004; Piertney et al., 2005), por lo que la sistemática de los arvicolinos está en plena revisión (Repenning, 1968; Chaline et al., 1999). En este trabajo seguiremos la propuesta de Chaline et al. (1999) para la sistemática de la subfamilia Arvicolinae, y la nomenclatura y análisis de parámetros de van der Meulen (1973).

El elemento más importante de la dentición es el primer molar inferior (a partir de ahora m1). Gran parte del análisis morfométrico se hace sobre la superficie oclusal de este diente (van der Meulen, 1973).

Género Arvicola Lacépède, 1799

\section{Arvicola terrestris (Linnaeus, 1758)}

Fig. 9.a-9.d

Las especies del género Arvicola pertenecen al grupo de ratas toperas o ratas de agua en España (topillos de agua en Europa). La especie A. terrestris es el arvicolino más grande de la fauna europea, aunque en la Península Ibérica le supera ligeramente en tamaño la rata de agua mediterránea, Arvicola sapidus Miller, 1908. La especie A. terrestris tiene el esmalte de los molares con diferenciación tipo Microtus, es decir, ligeramente más grueso en la parte mesial de los triángulos de la superficie oclusal que en la distal. En la especie A. sapidus la diferenciación es la inversa, con el esmalte más grueso en la parte distal, lo que se conoce por esmalte tipo Mimomys Major, 1902 (Fig. 9).

Hábitat y distribución geográfica: en la actualidad la rata de agua norteña tiene una amplia distribución EuroAsiática. En España se halla sólo en el norte, en la zona Euro-Siberiana. En el resto de Eurasia, donde no hay competencia con A. sapidus habita en medios fluviales y lacustres, nidificando en sus orillas. Sin embargo en presencia de la rata de agua mediterránea, se retira a los prados y vegas de los ríos. Dado su gran tamaño suele ser la presa principal del búho real (Bubo bubo), constituyendo en ocasiones su única dieta (Frafjord, 2003). Esto puede repercutir en la composición de las asociaciones de pequeños mamíferos, si el principal predador de los alrededores del yacimiento es el búho, por lo que un aumento en el número de ambas especies de Arvicola, debe de ser analizado con precaución.

Distribución estratigráfica: Arvicola terrestris se encuentra desde la segunda mitad del Pleistoceno medio en Europa (Heinrich, 1990). Es relativamente frecuente en los yacimientos del Pleistoceno tardío de la Cornisa Cantábrica (Pokines, 1998).

\section{Arvicola sapidus Miller, 1908} Fig. 9.e-9.g

Externamente A. sapidus o rata de agua meridional se asemeja a la norteña, A. terrestris. Es el arvicolino de mayor tamaño de la fauna de roedores española. Se diferencia de A.terrestris por la forma del complejo anterior y por el esmalte diferenciado plesiomórfico, tipo Mimomys.

Hábitat y distribución geográfica: especie típica de orillas de ríos y acequias de regadío de la Península Ibérica y Sur-Centro de Francia (Pokines, 1998; observaciones personales y Colectivo de Salas de los Infantes, Burgos). Prefiere zonas con aguas estancadas y riberas densamente pobladas y en zonas contaminadas es desplazada por la rata común (Arrizabalaga et al., 1986). Infrecuente en el norte de España o Francia; al igual que durante el Pleistoceno-Holoceno (Zabala, 1983; Ventura \& Sans-Fuentes, 1997; Pokines, 1998). Desconocemos cuándo hace su entrada en la Cornisa Cantábrica pues sólo se encuentra en el Gravetiense de Rascaño 7 (Altuna, 1981), el Solutrense de Las Caldas y La Riera, el Magdaleniense inferior de El Juyo nivel 8 (Pokines, 1998) y en el Magdaleniense inferior y comienzos del Holoceno del Mirón (Tabla 2). 
En el Pleistoceno medio hay numerosas citas con confer o affinis, que indican que la especie está aún por revisar (Cuenca-Bescós et al., 1999).

Distribución estratigráfica: La especie Arvicola sapidus aparece en el Pleistoceno medio. El origen de la rata de

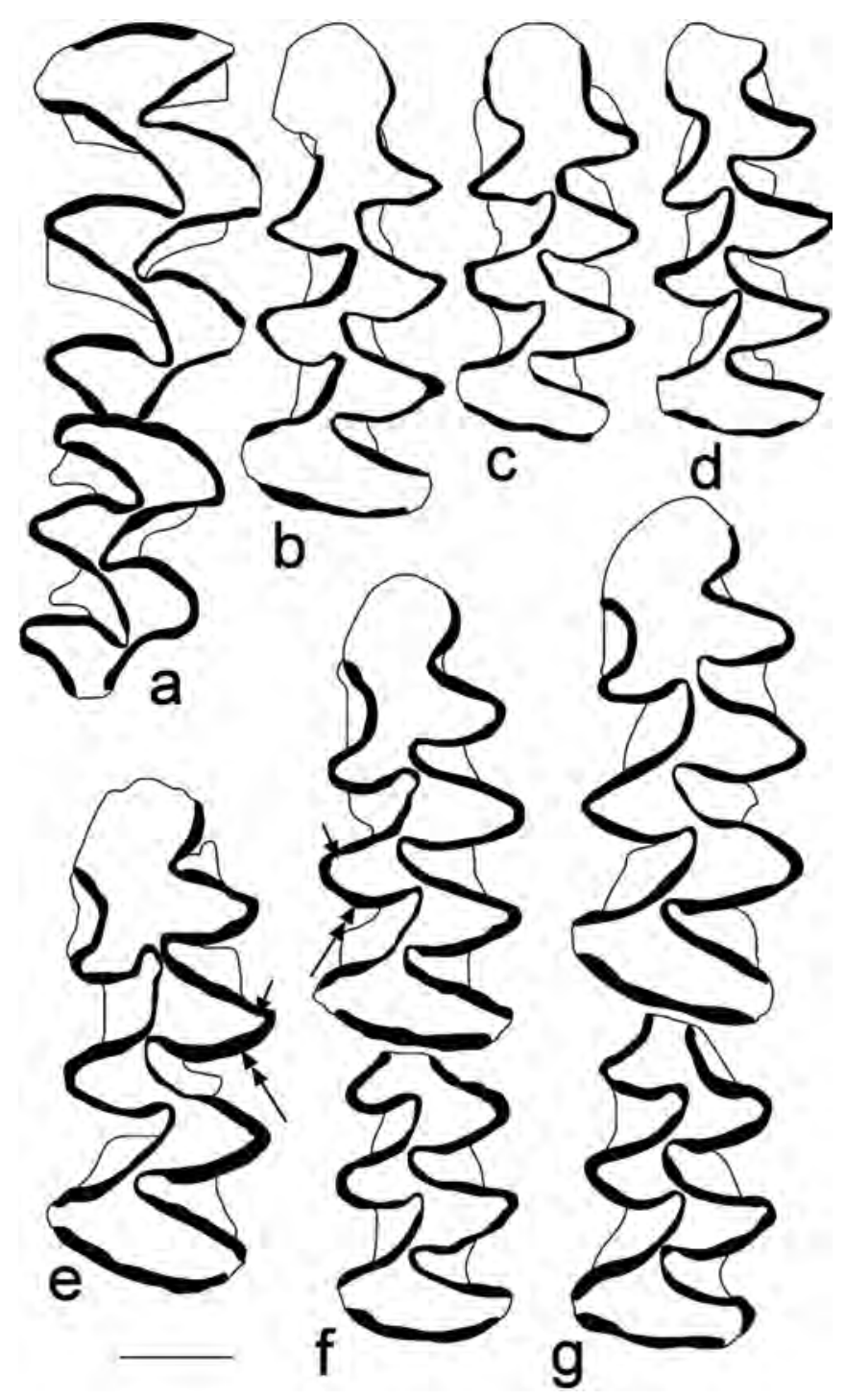

agua meridional es aún confuso. Se ha discutido mucho sobre su evolución a partir de Mimomys savini Hinton, 1910, que daría lugar a A. terrestris y A. sapidus, clado que se originaría en el Pleistoceno medio. Sin embargo los autores están en desacuerdo sobre la especie ancestral que da origen a A. sapidus (Ruiz Bustos \& Sesé, 1985; Ruiz Bustos, 1988; Koenigswald \& Kolfschoten, 1996; Abbassi et al., 1998).

Género Microtus Schrank, 1798

\section{Microtus agrestis (Linnaeus, 1761) Fig. 10.f}

Las especies de los géneros Microtus, Terricola y Chionomys tienen el esmalte diferenciado tipo Microtus (Fig. 10). La especie M. agrestis es de tamaño mediano; después de Chionomys nivalis es el tercer arvicolino en tamaño del Mirón. Carece de raíces y tiene cemento en los entrantes. El m1 tiene 4 triángulos casi cerrados en el complejo anterior. Se caracteriza por la asimetría y alternancia de los triángulos t4 y t5 y t6-t7 así como la fuerte alternancia de los ángulos entrantes, lo que lo diferencia de $M$. arvalis. Además, en M. agrestis el M2 (segundo molar superior) tiene tres salientes linguales o, lo que es lo mismo, 4 triángulos cerrados. Como ambas especies son morfológicamente semejantes, hay autores que las agrupan (Pokines, 1998; Baena et al., 2005).

Hábitat y distribución geográfica: también se le conoce como topillo agreste o de montaña. El actual M. agrestis vive en el Norte de la Península Ibérica y en el Norte de Europa y Asia, desde el Reino Unido y la Península Escandinava hasta Siberia. En el norte de la Península Ibérica, se encuentra desde los Pirineos a Galicia y Norte de Portugal y falta en la región mediterránea. Prefiere los pastos húmedos, márgenes de bosque e incluso páramos y dunas en Europa (Pokines, 1998). En España es un indicador de clima atlántico. Se encuentra en el Montseny, una montaña mediterránea, en la que, por su altura, se de-

Figura 9. Arvicolinos, Arvicola terrestris (Linnaeus, 1758) y Arvicola sapidus Miller, 1908 (Arvicolinae, Rodentia) del Cuaternario de la Cueva del Mirón, Ramales de la Victoria, Cantabria. a-d: dibujos de cámara clara de la superficie occlusal de los molares de Arvicola terrestris; a: maxilar izquierdo con M1 y M2 del nivel 3; b: m1 izquierdo del nivel 6; c-d: m1 izquierdos del nivel 3; e-g: Arvicola sapidus del nivel 10, $\mathrm{m} 1$ izquierdo (e), mandíbula (f-g) con m1m2 derechos (los dibujos se han invertido, para facilitar la comparación). Las flechas indican el mayor grosor de esmalte de la parte posterior de los triángulos de esmalte de Arvicola sapidus en relación con los de A. terrestris. Observar también el mayor tamaño (longitud y anchura) de los molares de A. sapidus. Dibujos con cámara clara. La escala representa $1 \mathrm{~mm}$.

Arvicolinae, Arvicola terrestris (Linnaeus, 1758) and Arvicola sapidus Miller, 1908 (Arvicolinae, Rodentia) of the Quaternary of El Mirón Cave, Ramales de la Victoria, Cantabria, Spain. a-d: Light camera drawings of the occlusal surface of the molars of Arvicola terrestris; a: left maxila with M1 and M2 from level 3; b: left m1 from level 6; $c$-d: left $\mathrm{ml}$ from level 3; $\boldsymbol{e}-\mathrm{g}$ : Arvicola sapidus from level 10, left $\mathrm{ml}(\boldsymbol{e})$, right mandible $(\boldsymbol{f}-\boldsymbol{g})$ with $\mathrm{m} 1 \mathrm{~m} 2$ ( $\mathrm{f}$ and $\mathrm{g}$ drawings reversed to make possible the comparisons). The arrows indicate the enamel differenciation, thicker in the posterior part of the triangles of Arvicola sapidus; thicker in the anterior part in A. terrestris. Observe also the bigger size of A. sapidus in relation to A. terrestris. Bars represents $1 \mathrm{~mm}$. 


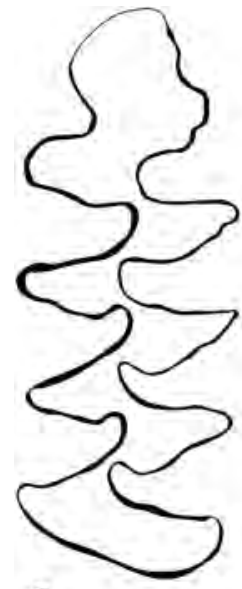

a

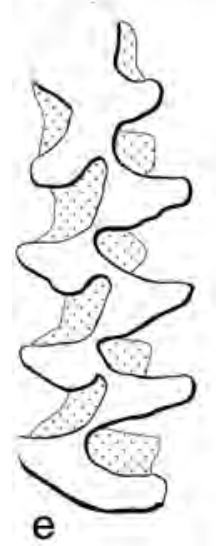

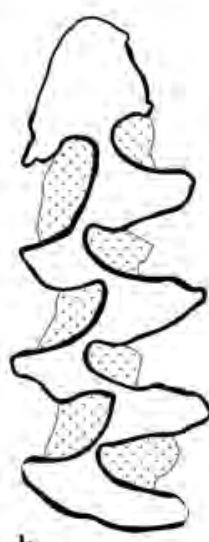

b

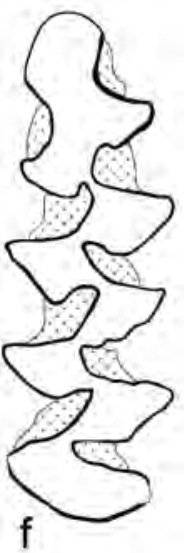

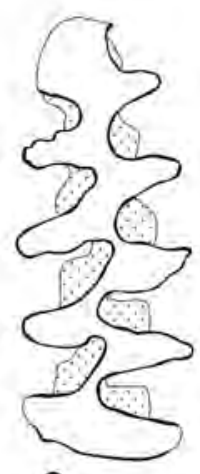

C

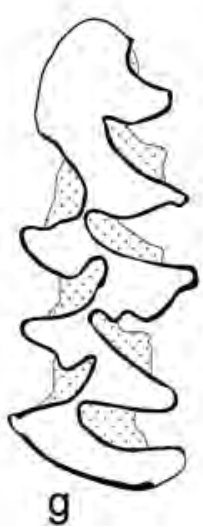

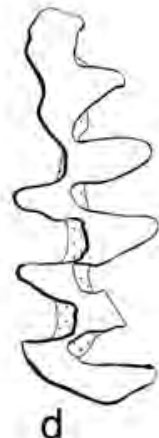

d

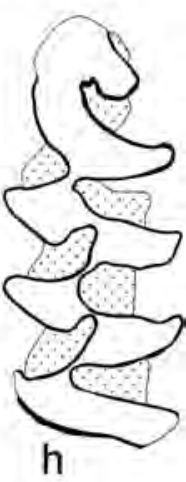

Figura 10. Otros Arvicolinos (Rodentia) del Cuaternario de la Cueva del Mirón, Ramales de la Victoria, Cantabria. Dibujos con cámara clara de la superficie occlusal de los m1. Todos son molares izquierdos excepto el b, que se ha invertido para facilitar la comparación. a: Pliomys lenki Heller, 1930 del nivel 130; b: Chionomys nivalis (Martins, 1842) del nivel 128 (invertido); c: Terricola lusitanicus Gerbe, 1879 del nivel 17; d: Microtus gregalis Pallas, 1779 del nivel 113; e: Microtus arvalis (Pallas, 1779) del nivel 13; f: Microtus agrestis (Linnaeus, 1761) del nivel 107; g-h: Microtus oeconomus (Pallas, 1776) de los niveles 124 y 12 respectivamente. La escala representa $1 \mathrm{~mm}$.

Other Arvicolinae (Rodentia) of the Quaternary of El Mirón Cave, Ramales de la Victoria, Cantabria Spain. Light camera drawings of the occlusal surface of the m1. All are left molars but the b, reversed to make possible the comparisons. a: Pliomys lenki Heller, 1930 from level 130; b: Chionomys nivalis (Martins, 1842) from level 128 (reversed); c: Terricola lusitanicus Gerbe, 1879 from level 17; d: Microtus gregalis Pallas, 1779 from level 113; $\boldsymbol{e}$ : Microtus arvalis (Pallas, 1779) from level 13; $f$ : Microtus agrestis (Linnaeus, 1761) from level 107; $\boldsymbol{g}-\boldsymbol{h}$ : Microtus oeconomus (Pallas, 1776) from levels 124 and 12 respectively. Bars represent $1 \mathrm{~mm}$. sarrollan ecosistemas más septentrionales: en el encinar, el hayedo, las parcelas desforestadas con cobertura herbácea, e incluso en muros de piedra y campos de cultivo (Arrizabalaga et al., 1986).

Distribución estratigráfica: las primeras citas de formas "agrestes" se conocen desde el Pleistoceno inferior (Villany, 8-11, en Hungría, Maul, 1990). Sin embargo el verdadero topillo agreste actual hace su aparición más tardíamente, a finales del Pleistoceno medio en Europa (Marquet, 1989) y durante el Pleistoceno superior en España (Villalta, 1972) y la región Cántabra (Pemán, 1990b).

\section{Microtus arvalis (Pallas, 1779) Fig. 10.e}

El topillo campesino o común tiene el m1 semejante al de $M$. agrestis, pero se diferencia de éste por la disposición casi simétrica y en paralelo de t4-t5 y especialmente de t6-t7, así como de los correspondientes ángulos entrantes; esto le confiere un complejo anterior más redondeado en contraste con el más anguloso de $M$. agrestis. También es de talla ligeramente menor, aunque se necesita una muestra lo suficientemente grande para poder estimar la diferencia. El M2 tiene dos salientes linguales o tres triángulos cerrados, a diferencia del M2 de M. agrestis que tiene 4 triángulos cerrados.

Hábitat y distribución geográfica: $M$. arvalis tiene una repartición semejante a la de $M$. agrestis aunque es una especie más oportunista, con una distribución más extensa y menos discontinua que la del topillo agreste. También en la Península Ibérica se extiende más hacia el sur y puede encontrarse en multitud de ámbitos, desde pastos a bosques caducifolios y coníferas (Palacios, 1988; Alcántara de la Fuente, 1992; González Esteban et al., 1994; Blanco, 1998b; Pokines, 1998), siempre con cierta humedad; por lo que las actuales condiciones de aridez del mediterráneo le han obligado a refugiarse en los macizos montañosos (Palomo \& Gisbert, 2002) y ha desaparecido de áreas costeras del Mediterráneo Español en las que vivió durante el Pleistoceno superior (Guillem, 1995).

Distribución estratigráfica: al igual que el topillo agreste, las formas "arvalis" aparecen ya en el Pleistoceno inferior (Maul, 1990). Sin embargo M. arvalis aparece en Pleistoceno medio de España (Arribas, 1994), y resto de Europa (Rekovets \& Nadachowski, 1995) algo más tempranamente que $M$. agrestis.

\section{Microtus oeconomus (Pallas, 1776)}

Fig. 10.g-10.h

El topillo de los pantanos, topillo ártico, o de los humedales fríos, es el más escaso de los Microtus del Mi- 
rón (Tabla 2). El m1 tiene tres triángulos cerrados, con $\mathrm{t} 4$ y t5 alternos y éste último confluye ampliamente con el t7 y el lóbulo anterior. El complejo anterior es asimétrico pues el t6 es un saliente apenas marcado. El entrante lingual mesial es reducido.

Hábitat y distribución geográfica: $M$. oeconomus, es un habitante típico de la Tundra y del norte de la Taiga Holártica, desde Canadá hasta Holanda y Escandinavia; donde se encuentra en llanos húmedos, turberas y pantanos. Aunque en la actualidad se encuentra bien representado en Europa norte y central (Nadachowski, 1982; Pokines, 1998) desaparece de las Islas Británicas (y probablemente de Europa occidental al norte de los Pirineos) a comienzos del Holoceno (Sutcliffe \& Kowalski, 1976).

La desaparición de esta especie en la Península Ibérica es más reciente, se ha encontrado en los niveles romanos de la Cueva de Amalda (Pemán, 1990a, b) y en los niveles 3 y 5 (Bronce temprano y Calcolítico) del Mirón (Tabla 2). M. oeconomus es un animal solitario que no puede competir con $M$. arvalis, ya que este último forma grandes grupos (Pokines, 1998), factor que hay que tener en cuenta al analizar su distribución estratigráfica. Aunque tenemos pocos datos del resto de la Península, una de las últimas citas de M. oeconomus es la de los niveles tardiglaciares de la Cueva Dels Ermitons, en Gerona (Alcalde Gurt, 1982). Su presencia en los niveles holocenos del Mirón y Amalda es una de las últimas conocidas en toda España. En los niveles Magdalenienses (V, VI y VI') de Erralla se encuentra en grandes cantidades, al igual que $M$. arvalis - agrestis (ver Pemán, 1985) por lo que podemos deducir que la extensión de las zonas húmedas era importante durante el Magdaleniense en Erralla. La proximidad de Erralla y Amalda hacen pensar que el paisaje de la zona (Cestona) era abierto, húmedo y relativamente frío durante buena parte del Magdaleniense y hasta época Romana en el Holoceno. En El Mirón M. oеconomus, aunque escaso, está presente en casi toda la secuencia coincidiendo en general con $M$. arvalis y períodos de abundancia de $A$. terrestris (Tabla 2, Fig. 12) por lo que podemos pensar que esta asociación representa momentos de mayor humedad. La presencia de Neomys fodiens, la musaraña acuática, también concuerda. Hay que señalar que, salvo en el nivel 130 de la Rampa, M. oeconomus está presente en casi toda la secuencia del Mirón, tanto en el Pleistoceno como en buena parte del Holoceno, hasta los 2.000 años. Sin embargo falta durante el Aziliense (por encima de los niveles 104.2-102 del Corral), datado entre los 11.500 y 9.000 años (Straus, 2005). El significado de esta desaparición debe de estar ligado con un período de sequedad, ¿el Dryas III?, en el que desaparecerían los humedales que constituyen el hábitat óptimo de la especie. El nivel 106 representa un período de apertura, con la aparición de prados en detrimento del bosque, seguramente ligado a la sequedad (Figs. 12,13), donde es significativo el gran número de individuos de $M$. arvalis y $M$. agrestis, ambas especies de prados abiertos (Fig. 13).

Distribución estratigráfica: como en otras especies de Microtus, las primeras referencias de formas con morfología de M. oeconomus son del Pleistoceno inferior (Maul, 1990; Rekovets \& Nadachowski, 1995) de Europa centrooriental. También hay formas parecidas en el Pleistoceno medio, como M. oeconomus-ratticepoides (López Antoñanzas \& Cuenca-Bescós, 2002). La especie M. oeconomus aparece en Europa occidental (Francia, España) en el Pleistoceno superior (Alcalde Gurt, 1982; Pemán, 1990a, b; Eastham, 1995; Pokines, 1998).

\section{Microtus gregalis Pallas, 1779 Fig. 10.d}

Sólo hay un ejemplar de Microtus gregalis (Tabla 2) en El Mirón, en el nivel 113 del Corral. Los m1 de este topillo se distinguen del resto de las especies de Microtus del Mirón por su acusada asimetría labio-lingual y la comunicación del reducido a inexistente triángulo 6 con el complejo anterior. Tiene el $\mathrm{m} 1$ de mayor longitud, en relación con la anchura, que otros topillos, lo que le confiere un aspecto grácil.

Hábitat y distribución geográfica: El topillo de cráneo estrecho, M. gregalis, habita en la tundra y estepa Euro-Siberiana donde vive en complejas colonias de madrigueras con numerosas entradas y salidas ocupadas durante largos períodos de tiempo (Pokines, 1998).

Distribución estratigráfica: La especie $M$. gregalis se cita en yacimientos del Pleistoceno inferior de Europa oriental y central (Maul, 1990) aunque aparentemente sólo al final del Pleistoceno medio y únicamente durante los momentos más fríos del Pleistoceno superior se encuentra en Europa occidental, en el Reino Unido (Currant, 1986), Francia (Marquet, 1989) y España (Pokines, 1998; Sesé, 2005). Su presencia en el nivel 113 del Mirón confirma la entrada de este roedor en España, exclusivamente en la Región Cantábrica, al final del Pleistoceno superior.

Género Chionomys Miller, 1908

\section{Chionomys nivalis (Martins, 1842)}

Fig. 10.b

La especie Chionomys nivalis es el topillo "tipo" Microtus más grande de la península, aunque Iberomys cabrerae (Thomas, 1906) tiene los molares más anchos transversalmente. El m1 de Ch. nivalis es característico por su lóbulo anterior, en forma de seta con el sombrero fuertemente inclinado hacia el lado labial. En el lado lingual sólo hay 
4 entrantes, uno menos que en la mayoría de las especies de Microtus. En los individuos juveniles este carácter está menos marcado y puede confundirse con Microtus agrestis ya que el cuarto entrante lingual varía de ligeramente provergente en los individuos juveniles a muy provergente en los adultos.

Hábitat y distribución geográfica: Es un habitante típico de alta montaña, por encima de la línea de árboles de las regiones alpinas, hasta los 2000 metros de altura, aunque el rango de altitud puede variar y depender de otros factores (Mitchell-Jones et al., 1999; Luque-Larena et al., 2002), por lo que se le conoce también como ratilla nival o neverón. Su hábitat parece estar más controlado por la disponibilidad de terrenos rocosos con fisuras o pedreras, soleados, sin vegetación, al borde de pastos, que por la altura (Pokines, 1998). También, durante el Pleistoceno superior y Holoceno, hasta el calcolítico, Ch. nivalis se encuentra en yacimientos situados en cotas bajas, a menos de 250 metros sobre el actual nivel del mar, como Amalda (205 m), Aizbiarte (220 m), Cueto de la Mina (complejo de La Llera, al lado de la cueva de La Riera, 30 m), Ekain (90 m), entre otros (Pokines, 1998). Es posible que el incremento de cota con respecto al paleonivel Pleistoceno del mar debido a la glaciación haya influido en esta distribución. En el resto de España y sur de Francia el Musteriense pudo ser una época favorable a la dispersión del neverón, pues se encuentra en zonas de las que ha desaparecido en la actualidad como el yacimiento francés de l'Hortus (Chaline, 1972; Cabrera-Millet et al., 1982) y en España en el de la Carigüela, en Granada (Ruiz Bustos, 2000), Los Toros, en Teruel (Gil \& Sesé, 1985) y Gabasa en Huesca (Gil \& Lanchares, 1987). Es probable que en los momentos más fríos del Pleistoceno superior la expansión de zonas rocosas, sin vegetación fueran favorables a la dispersión de la especie a cotas más bajas, o montañas del interior peninsular. La mejora climática del Holoceno no debió de ser tan uniforme como para reducir por completo las poblaciones de $C h$. nivalis que han sobrevivido hasta la actualidad como demes aislados en macizos montañosos de la Península Ibérica (García-Perea \& Gisbert, 1997). También en el resto de Europa se encuentra en los macizos montañosos mediterráneos, desde los Pirineos hasta los Tatra pasando por los Alpes y por el mediterráneo oriental desde el Monte Olimpus en Grecia hasta el Líbano e Israel y en el oriente medio hasta los Montes Zagros de Irán (Pokines, 1998).

Distribución estratigráfica: la morfología "nivalis" se encuentra ya desde el final del Pleistoceno inferior. Aunque la especie $C h$. nivalis aparece al final del Pleistoceno medio en Francia (Desclaux, 1996-1997), no es bien conocida hasta el Pleistoceno superior en Francia (Marquet, 1989) y España (Sesé Benito \& Soto Rodríguez, 1988; Pokines, 1998).
Género Terricola Fatio, 1867

\section{Terricola lusitanicus Gerbe, 1879}

Fig. 10.c

El grado de confluencia de los triángulos 6 y 7 , que forman el segundo rombo pitimiano, así como la inclinación de los triángulos labiales permiten clasificar a la especie de Terricola de El Miron como T. lusitanicus. En la Península Ibérica hay en la actualidad tres o cuatro especies de $T e$ rricola según los autores: T. duodecimcostatus (de SélysLongchamps, 1839), T. pyrenaicus (de Sélys-Longchamps, 1839) y T. lusitanicus (Gerbe, 1879) en Brunet-Lecomte \& Chaline (1993) o cuatro, con T. gerbei (Gerbe, 1879), en Niethammer \& Krapp (1982) y Giannoni et al. (1993). La diferenciación morfológica de las especies de Terricola es complicada (Brunet-Lecomte et al., 1987; Brunet Lecomte \& Chaline, 1990, 1993). La especie de Terricola del Mirón tiene el $\mathrm{m} 1$ con morfología de T. lusitanicus: el "rombo pitimiano 2" está relativamente aislado de la parte anterior en T. lusitanicus y en T. pyrenaicus mientras que en T. duodecimcostatus confluye ampliamente. Cuando T. lusitanicus y T. duodecimcostatus son alopátricos este carácter es más variable e individuos aislados pueden ser difíciles de distinguir basándonos solo en este rasgo (Brunet Lecomte et al., 1987). La distinción entre T. lusitanicus y T. pyrenaicus se basa en una mayor inclinación hacia distal de los triángulos labiales de T. lusitanicus. También es de notar el abombamiento de los ápices labiales de estos triángulos, lo que constituye una novedad evolutiva de la especie T. lusitanicus.

Hábitat y distribución geográfica: Las especies de $T e$ rricola de la Península Ibérica son formas cavadoras que presentan gran similitud en sus hábitos; sin embargo, $T$. duodecimcostatus excava y empuja la tierra hacia delante con ayuda de los incisivos mientras que T. lusitanicus y $T$. pyrenaicus empujan la tierra hacia atrás con ayuda de sus miembros posteriores (Giannoni et al., 1993). La utilización de los incisivos (al igual que en Arvicola terrestris) está en relación con la excavación de suelos más duros que los de las especies que lo hacen con los miembros posteriores (Giannoni et al., 1992). Terricola lusitanicus necesita suelos profundos para hacer sus madrigueras, por lo que está ligada a clima más atlántico que $T$. duodecimcostatus. Ambas especies son simpátricas en Castilla y León mientras que en Cantabria sólo se encuentra T. lusitanicus, especie que puede estar en simpatría con T. pyrenaicus (Brunet-Lecomte et al., 1987; Brunet-Lecomte, 1991). El topillo pirenaico prefiere los suelos profundos, con una buena cubierta vegetal, mientras que el lusitano los prefiere más someros y con afloramientos rocosos dispersos (Borghi et al., 1990).

Distribución estratigráfica: las especies de Terricola actuales de la Península Ibérica aparecen tardíamente, en el Pleistoceno superior (Pokines, 1998; Guillem, 1995a, b). 
Género Clethrionomys Tilesius, 1850

\section{Clethrionomys glareolus (Schreber, 1780)} Fig. 11.h-11.i

La especie $C$. glareolus es el único arvicolino actual de la península Ibérica que tiene a la vez raíces y cemento en los entrantes labiales y linguales (Fig. 11). Otra peculiaridad del topillo rojo es el esmalte continuo, sin zonas libres (salvo en individuos seniles) y con el mismo grosor en todo el perímetro oclusal. Los molares tienen triángulos confluyentes, no cerrados o aislados como en el resto de los arvicolinos actuales. Salvo en el nivel 7, su presencia es constante y prácticamente invariable durante el Holoceno del Mirón, sin embargo al final del Pleistoceno es escasa y está ausente en los niveles anteriores al Magdaleniense (ver tablas 1 y 2 ).

Hábitat y distribución geográfica: El topillo rojo es uno de los pocos arvicolinos actuales que vive en bosque caducifolio, más o menos abierto o en zonas en donde la vegetación es arbustiva o compuesta por hierbas altas. Es un buen indicador de paisaje con cobertera vegetal en un clima templado húmedo (Pemán, 1985, 1990a, b). Se encuentra en la Eurasia templada, desde el lago Baikal hasta las Islas Británicas. En España tiene una distribución actual septentrional (Ventura et al., 1993; Pokines, 1998) aunque puede encontrarse en los macizos montañosos del Levante español que gozan de un clima eurosiberiano como el mencionado macizo del Montseny en Cataluña (Arrizabalaga et al., 1986).

Distribución estratigráfica: la especie $C$. glareolus aparece en el Pleistoceno inferior y desde entonces tiene una amplia distribución Europea hasta la actualidad (Tesakov, 1996).

\section{Género Pliomys Méhely, 1914}

\section{Pliomys lenki Heller, 1930}

Fig. 10.a

Se caracteriza por tener raíces y carecer de cemento en los ángulos entrantes (Fig. 10). Su tamaño relativamente grande en relación con otros arvicolinos (a excepción de las especies de Arvicola), unido a la presencia de raíces y la ausencia de cemento en los entrantes hacen de esta especie un microtino inconfundible. Desde su descripción original, en el yacimiento de Sackdilling (Alemania) los estudios sobre Pliomys lenki muestran que es una especie con una morfología relativamente estable y además es muy longeva (Bartolomei et al., 1975; Chaline, 1975) en relación con las rápidas radiaciones que sufren los demás arvicolinos. A falta de un estudio sistemático más completo podemos decir por la talla que $P$. lenki del Mirón se encuentra en el extremo de mayor tamaño de las poblaciones de Pliomys lenki del Pleistoceno superior. Algunos autores como Maul \& Markova (2007), ponen P. lenki en sinonimia con P. coronensis (Méhely, 1914), especie que se extingue en Europa central en el Pleistoceno medio. A falta de una revisión del género Pliomys, continuaremos utilizando P. lenki para las formas que se encuentran en Europa Occidental. El aumento de talla de Pliomys lenki es también señalado por Pemán (1990 a) en el yacimiento de Amalda (niveles IVa-X) y como en ésta localidad, el esmalte presenta una diferenciación de tipo Microtus. En Boscochiesanuova, Italia (Bartolomei et al., 1975), es también notable la diferenciación de esmalte. Esta evolución de la diferenciación del grosor de esmalte debe de estar ligada con el aumento de la hipsodoncia y de la aparición de las zonas libres de esmalte como también ponen de manifiesto otros autores para otras líneas de arvicolinos (Maul, 2001).

Hábitat y distribución geográfica: El género Pliomys está relacionado con Dinaromys bogdanovi (Martino, 1922) endemismo Balcánico actual (Chaline et al., 1999) conocido también como topillo de Martino o de los Balcanes (Serbia, Croacia, Bosnia-Herzegovina, Montenegro y Macedonia). D. bogdanovi es una especie de alta montaña, comparable por su ecología con Chionomys nivalis. Por sus relaciones filogenéticas y yacimientos en los que se encuentra, es posible que Pliomys lenki tuviera una ecología similar a la de ambas especies actuales, el neverón y el topillo balcánico.

Distribución estratigráfica: la especie Pliomys lenki ha sido citada en numerosos yacimientos del Pleistoceno inferior y medio de Alemania, Polonia, Rumania, Hungría, la antigua Checoslovaquia, Italia, Francia y España (Bartolomei et al., 1975). Es posible que la especie perviva en Europa meridional (Italia y Francia) hasta el final del Pleistoceno medio / comienzos del superior (Chaline, 1975; Chaline \& Marquet, 1976; Marquet, 1989; Ferraris et al., 1990), sin embargo es en la Península Ibérica y un único yacimiento en Francia, la Grotte du Sanglier (Marquet, 2001), donde la especie sobrevive hasta el final del Pleistoceno superior, poco antes del período climático frío conocido como Dryas III, al final de la última glaciación (Würm). La especie se refugia en España durante gran parte del Würm, encontrándose en los yacimientos de El Juyo, Amalda, Lezetxiki y Ekain (Altuna, 1972; Zabala, 1984; Pemán, 1990a, b; Pokines, 1998) en el Cantábrico, Els Ermitons en Gerona (Alcalde Gurt, 1982), en Gabasa, Huesca (Gil \& Lanchares, 1988) e incluso en yacimientos más meridionales y mediterráneos, como Cova Negra, en el sur de Valencia (Guillem, 1995). Su presencia en El Mirón es intermitente, reaparece en el nivel 106, tras haber desaparecido de niveles anteriores, para finalmente extinguirse. Esta última aparición podría tratarse de un efecto Lázaro (Fara, 2001; Cuenca-Bescós et al., 2006). 
$P$. lenki parece ser una especie ligada a medios esteparios, abiertos, montanos y fríos según la mayoría de los autores (Bartolomei et al., 1975; Marquet, 1989; este trabajo). Como resalta Chaline (1975), la especie migra durante el Pleistoceno desde el este hacia el suroeste de Europa, persistiendo únicamente en España (este trabajo) y sur de Francia (Marquet, 2001) hasta el final del Pleistoceno. ¿Está relacionada esta migración con el enfriamiento progresivo del clima, siempre más benigno en España que en el resto de Europa continental?, ¿O está relacionada mas con una entrada de otros pequeños mamíferos que compiten por el mismo medio?

Durante el Pleistoceno Superior su presencia está relacionada con momentos fríos en Gabasa, Huesca (Gil \& Lanchares, 1988) y en Cova Negra, Valencia, donde Pliomys se encuentra asociado con Allocricetus Schaub, 1930, en la fase seca (F, unos 20.000 años, Guillem, 1995). Por otra parte, su presencia en general en yacimientos en cuevas hace pensar que $P$. lenki está ligada a un substrato rocoso. En cuanto a la competencia con otros mamíferos sólo podemos mencionar que la entrada de especies adaptadas a los lugares favoritos en que habita $P$. lenki, como Chionomys nivalis, podría ser la causa final de su extinción por competencia.

\section{Subfamilia Murinae Illiger, 1815}

Los murinos son roedores con dientes yugales radiculados, coronas bajas (braquidontas) y superficie oclusal formada por 4 a 6 cúspides principales y un número variable de cúspides secundarias en el lado labial de los molares. Su fórmula dental es 1Ii3Mm como la de los arvicolinos.

Género Apodemus Kaup, 1829

\section{Apodemus sylvaticus Linnaeus, 1758 o Apodemus flavicollis (Melchior, 1834)}

El género Apodemus se caracteriza por tener la superficie oclusal con 6 cúspides principales en el primer molar (tanto inferior como superior), y 4 en los molares segundo y tercero. En la cara labial $\mathrm{m} 1$ tiene 3 cúspides secundarias, $\mathrm{m} 2$ de 2 a una y $\mathrm{m} 3$ es reducido, con la parte posterior acuminada. Las especies actuales de Apodemus de la Península Ibérica son A. sylvaticus y A. flavicollis, el ratón de campo y el ratón leonado respectivamente. Morfológicamente son muy parecidas, comparten numerosos caracteres dentales y aunque A. flavicollis tiene una talla mayor que A. sylvaticus, en simpatría sus medidas se solapan por lo que es bastante difícil separar ambas especies si no se hace un análisis morfométrico detallado. La diferencia de talla, manifiesta en Europa Central y Norte disminuye hacia el sur haciendo que la distinción entre las dos especies en la Península Ibérica (y en general en todas las penínsulas mediterráneas) sea problemática (Nores, 1988; Alcántara de la Fuente, 1992).

Hábitat y distribución geográfica: ambas especies tienen una distribución amplia, la especie A. flavicollis tiene una repartición discontinua en Europa y en España se encuentra sólo en el norte, desde los Pirineos hasta Asturias, mientras que $A$. sylvaticus es más mediterránea y se encuentra en toda la Península (Alcántara de la Fuente, 1992).

Distribución estratigráfica: ambas especies Apodemus sylvaticus y A. flavicollis se conocen desde el Pleistoceno inferior (Maul, 1990).

\section{Familia Myoxidae Gray, 1821}

Los glíridos o lirones son roedores que se caracterizan por tener la superficie oclusal de sus molares surcada por crestas transversales separadas por valles, tener raíces y ser braquidontos (Fig. 11).

Género Myoxus Zimmermann, 1780

$$
\begin{gathered}
\text { Myoxus glis (Linnaeus, 1766) } \\
\text { Fig. 11.f-11.g }
\end{gathered}
$$

Es el mayor de los lirones, y uno de los mayores roedores, europeos. Se distingue por tener los dientes de contorno rectangular a cuadrado y superficie oclusal plana, con crestas transversas claramente separadas por valles relativamente anchos. Estas crestas son de desarrollo continuo, labio-lingual. En los molares inferiores las crestas se giran hacia la parte anterior y en los superiores se curvan hacia la posterior. Entre las crestas principales hay crestas secundarias, más cortas, que no alcanzan las caras labial ni lingual.

Hábitat y distribución geográfica: El lirón gris es una especie de bosque cálido que habita en la actualidad en Europa Central y Meridional hasta el Cáucaso y en el norte de España, siendo pieza de caza en Europa central; también se encuentra en el sur de Inglaterra pero ésta podría ser una introducción de mediados de siglo XX (Krystufek \& Haberl, 2001). También puede ser un comensal ocasional (Pokines, 1998). En el yacimiento de Erralla aparece en niveles cálidos o templados (II, III, V) de la secuencia aunque asociado con especies mas frías, de espacios abiertos y heliófilas como el neverón (Pemán, 1985).

Distribución estratigráfica: el gran lirón gris Муохиs glis se conoce desde el Pleistoceno medio, en Europa central entra cuando desaparecen las especies de Myoxus del Pleistoceno inferior (Nadachowski, 1990). En Francia no aparece hasta la segunda mitad del Pleistoceno medio 

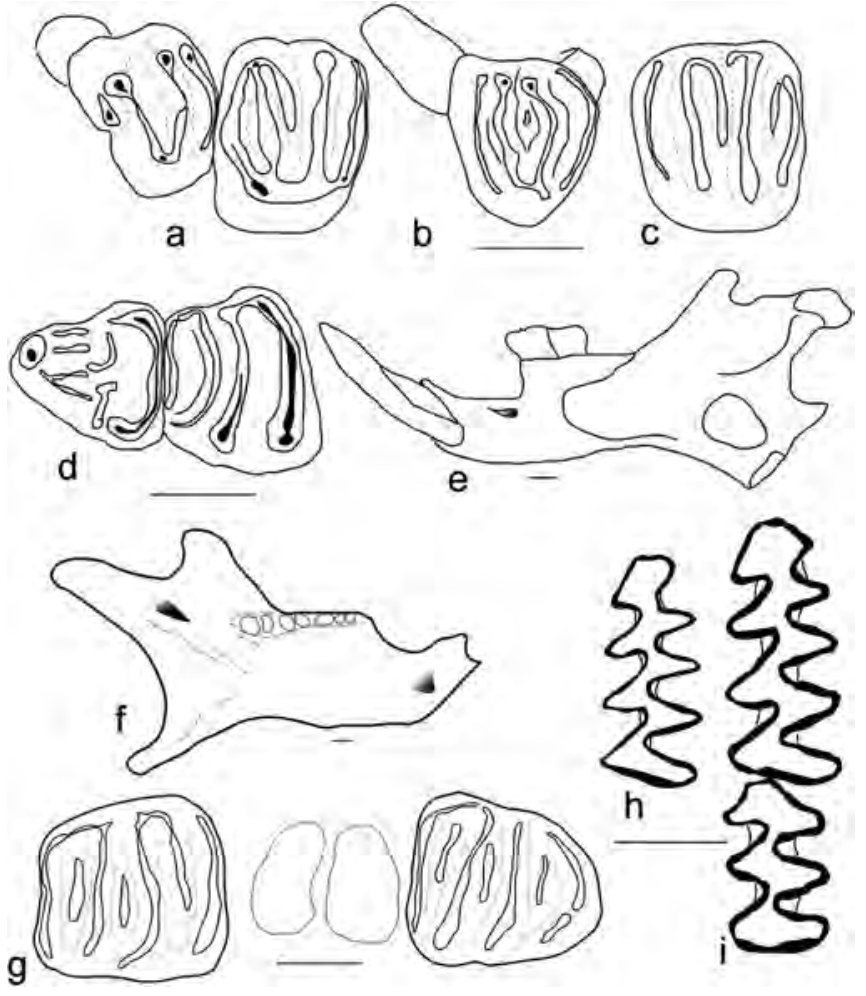

Figura 11. Otros arvicolinos y otros roedores del Cuaternario de la Cueva del Mirón, Ramales de la Victoria, Cantabria. Dibujos con cámara clara de la superficie occlusal de los molares y la cara lateral de las mandíbulas. a-g: molares y mandíbulas de Gliridos del nivel 10. a-e: Eliomys quercinus (Linnaeus, 1766); a: maxilar izquierdo con P4M1, b: maxilar izquierdo con D4, c: M12 derecho (invertido), d: mandíbula izquierda con p4m1, e: mandíbula izquierda en vista lateral. Observar el gran foramen de la lámina angular de la mandíbula, carácter apomorfico entre los roedores Cuaternarios de la Península Ibérica. f-g: Myoxus glis (Linnaeus, 1766); f: mandíbula izquierda, sin molares, en vista medial, g: mandíbula izquierda con m1 los alveolos de $\mathrm{m} 2$ y m3. h-i: Clethrionomys glareolus (Schreber, 1780); h: $\mathrm{m} 1$ izquierdo, i: mandíbula derecha con $\mathrm{m} 1 \mathrm{~m} 2$ (invertida). La escala representa $1 \mathrm{~mm}$. Other Arvicolinae and other rodents of the Quaternary of El Mirón Cave, Ramales de la Victoria, Cantabria, Spain. Light camera drawings of the occlusal surface of the molars and lateral and medial views of the mandibles. Some drawins are reversed to make comparisons easy. a-g: molars and mandibles of Gliridae from level 10. a-e: Eliomys quercinus (Linnaeus, 1766); $\boldsymbol{a}$ : left maxila with P4M1, $\boldsymbol{b}$ : left maxilla with D4, $\boldsymbol{c}$ : right M12 (reversed), $\boldsymbol{d}$ : left mandible with $\mathrm{p} 4 \mathrm{ml}, \boldsymbol{e}$ : left mandible in lateral view. See the big foramen in the angular laminae of the mandible, an apomorfic character among the Quaternary rodents of the Iberian Peninsula.f-g: Myoxus glis (Linnaeus, 1766); $f$ : left mandible, without molars, in medial view, $g$ : left mandible with $m 1$, alveoli of $m 2$ and $m 3$. $\boldsymbol{h}$-i: Clethrionomys glareolus (Schreber, 1780); $\boldsymbol{h}$ : left m1, $\boldsymbol{i}$ : right mandible with $\mathrm{mlm} 2$ (reversed). Bars represent $1 \mathrm{~mm}$.
(Desclaux, 1996-1997) y en España no se conoce más que en el Pleistoceno superior (Pokines, 1998).

Género Eliomys Wagner, 1840

\section{Eliomys quercinus (Linnaeus, 1766) \\ Fig. 11.a-11.e}

El lirón careto es un glírido de porte mediano, aunque es más pequeño que Myoxus glis sus molares son semejantes en tamaño. Es el único roedor español con un foramen amplio en la lámina angular de la mandíbula. Los molares son característicos por su superficie oclusal cóncava, con crestas transversas que recorren el diente labio-lingualmente y un gran desarrollo de las cúspides principales.

Hábitat y distribución geográfica: El lirón careto es una especie ampliamente distribuida por la Europa templada y Mediterránea, el norte de África y Levante. Se encuentra en los bosques y zonas de arbustos de toda la Península Ibérica (Moreno, 2002) ligado a claros pedregosos y como el lirón gris, es también un comensal ocasional. Es notable su ausencia en el Pleistoceno superior de Cantabria, pues sólo se conoce en el Auriñaciense de Cueto de la Mina (Pokines, 1998). Su presencia en yacimientos de la edad del Bronce $\left(\mathrm{C}^{14}=1.380-1.340 \mathrm{BP}\right)$ como La Encantada, en Ciudad Real puede estar relacionada con el hombre aunque de una manera indirecta, ya que el hombre favorece unas especies, por la creación de medios artificiales y elimina a otras (Morales Muñiz, 1986). Otro ejemplo de Eliomys ligado a enterramientos (y basureros) del Bronce es el de La Balsa la Tamariz, en Tauste, Zaragoza (Laplana \& Cuenca-Bescós, 1995). En El Mirón la especie entra al final del Magdaleniense, cuando comienza la expansión de los bosques en la Cornisa Cantábrica (aunque con desapariciones temporales debido al deterioro climático del Dryas III y desaparece después del óptimo climático del Holoceno, seguramente ligado a la deforestación provocada por el hombre a partir del Calcolítico (Tabla 2 y Fig. 12).

Distribución estratigráfica: el lirón careto se origina en el Mediterráneo y se conoce en España desde el Pleistoceno inferior, en secuencias como Casablanca, Castellón (Agustí \& Galobart, 1986).

\section{ANÁLISIS BIOESTRATIGRÁFICO DE LOS PEQUEÑOS MAMÍFEROS DE EL MIRÓN E IMPLICACIONES PALEOAMBIENTALES Y PALEOCLIMÁTICAS}

La distribución estratigráfica de los pequeños mamíferos del Mirón es variable según las especies. En la se- 
cuencia estratigráfica compuesta, en la que se han unido, utilizando criterios de correlación estratigráfica, cronológica y cultural, los cuatro sectores excavados, vemos que la mayoría de los pequeños mamíferos se encuentran en toda la secuencia, con variaciones en el número de individuos (Tabla 2 y Figs. 12, 13, 14). Pero hay especies que no cumplen este patrón:

Pliomys lenki se extingue en el Magdaleniense superior (Tabla 2, Fig. 12). Coincidiendo con la extinción de P. lenki, con un ligero solapamiento en el caso de Eliomys quercinus, aparecen las especies más ligadas al bosque de toda la secuencia, E. quercinus, Myoxus glis y Clethrionomys glareolus (Fig. 12). Coincidiendo con la aparición de las especies de bosque entra también la musaraña de dientes blancos, de carácter mediterráneo, Crocidura russula. Como vemos en la figura 14, la mediterraneidad, en función de la proporción entre los arvicolinos, roedores de medios abiertos y/o esteparios y los murinos, especies más mediterráneas (Alcántara de la Fuente, 1992), coincide también con la aparición de estas especies de bosque. El murino Apodemus sylvaticus, relacionado con bosque y lindes de bosque, aunque algo menos que los lirones, aumenta también en la parte alta de la secuencia, cuando se asientan las condiciones de mediterraneidad. Los arvicolinos, aunque no llegan a desaparecer del todo, disminuyen notablemente.

Es de notar que hacia el Holoceno tardío, durante el final del Bronce (Tabla 2 y Figs. 12,13) hay un incremento de arvicolinos de medios fríos y húmedos (M. oeconomus y Ch. nivalis), hecho que coincide con la desaparición de las especies de bosque (niveles $2+3$ y 3 , el 3 datado en 3.700 años BP). Este evento faunístico de la secuencia del Mirón se correlaciona tentativamente con la pequeña edad del hielo del final del Holoceno, que precede al período cálido Romano (Martínez-Cortizas et al., 1999) y que supuso un enfriamiento global que siguió al óptimo climático del Holoceno (Indermuhle et al., 1999; Uriarte Cantolla, 2003).

El aumento del bosque coincide más o menos con el llamado Óptimo Holoceno en el que subieron las temperaturas; antes del declive de temperatura de alrededor de los 2.000 años calibrados que precede al Período Romano Cálido del que hemos hablado (Martínez-Cortizas et $a l .$, 1999). El posterior declive del bosque y aumento de las especies ligadas a terrenos sin vegetación podría ser consecuencia de la deforestación que se va haciendo notoria especialmente a partir de finales del Bronce (Uriarte Cantolla, 2003).

La Península Ibérica se divide, por el clima y la distribución de la vegetación, en dos grandes regiones, la Eurosiberiana y la Mediterránea. Un indicador de mediterraneidad entre los pequeños mamíferos es por ejemplo el endemismo ibérico Iberomys cabrerae. Como esta especie falta en El Mirón hemos elaborado un índice de mediterraneidad a partir de las proporciones de Murinos+Glíridos (ratones y lirones respectivamente) con respecto a los $\mathrm{Ar}$ vicolinos (Fig. 14). Los primeros representan el clima mediterráneo (cálido) y los segundos al eurosiberiano (frío). Hemos elegido las tres secciones completas (dejando el sondeo de la Rampa) para elaborar este índice. En la Fig. 14 se puede observar que a partir del Holoceno inicial (Mesolítico), con algunas variaciones correspondientes a los enfriamientos Holocenos mencionados, se instala en España un régimen mediterráneo (Óptimo Holoceno) en el que aumenta el número de Murinos+Glíridos, indicadores el bosque mediterráneo.

Se observa que después del denominado óptimo climático del Holoceno, identificable en El Mirón en los niveles Mesolíticos hasta el final del Calcolítico (Figs. 12, 13 y 14) hay un deterioro importante en el número de especies, que disminuye drásticamente en los niveles recientes (1 y 2), lo que debe de estar relacionado con la escasez de las muestras por una parte y por otra, con una mengua de la actividad de las rapaces nocturnas al estar la Cueva ocupada permanentemente por los pastores y sus rebaños.

Es notable la persistencia de $M$. oeconomus y Chionomys nivalis hasta prácticamente el final del Holoceno, aunque ambas especies faltan en la actualidad en la franja costera Cantábica (Tabla 1). En el caso del neverón no ha desaparecido por completo de la Península Ibérica pues se encuentran poblaciones relictas en los macizos montañosos, donde quedan lugares favorables para esta especie, como roquedos soleados y desprovistos de vegetación (Luque-Larena et al., 2002). También en el Holoceno es de señalar la extinción (al menos local) del lirón careto, especie de bosque cálido que se encuentra en la actualidad en la zona. Las especies de múridos Mus (el ratón casero), Micromys minutus (el ratón espiguero) y Rattus (rata gris y negra) viven en la actualidad en Cantabria así como en el resto de España pero faltan en el Mirón. El único múrido presente en el Cuaternario del Mirón es Apodemus, que se encuentra bien representado en todos los niveles Holocenos aunque es raro en los niveles anteriores al Magdaleniense Superior. La falta de múridos "modernos" en El Mirón permite comprender algo más su dispersión en tiempos históricos: estos múridos no colonizan el Norte de España hasta prácticamente la actualidad (Pemán, 1985, 1990a, b; Pokines, 1998; este trabajo) y lo hacen probablemente a partir del momento en que la agricultura y el comercio se generalizan y extienden hacia el norte a través de rutas comerciales como la Ruta de la Plata que, al menos en el centro de la Península Ibérica, actúan como vías de dispersión del ratón casero y el gorrión común (Morales Muñíz et al., 1995).

Resumiendo, en la Tabla 2 y Fig. 12 vemos que la distribución de los roedores en el Pleistoceno-Holoceno del Mirón se caracteriza por:

1. La presencia esporádica de algunas especies como Arvicola sapidus, Microtus gregalis, Erinaceus, Sciurus, Galemy, entre otras. 


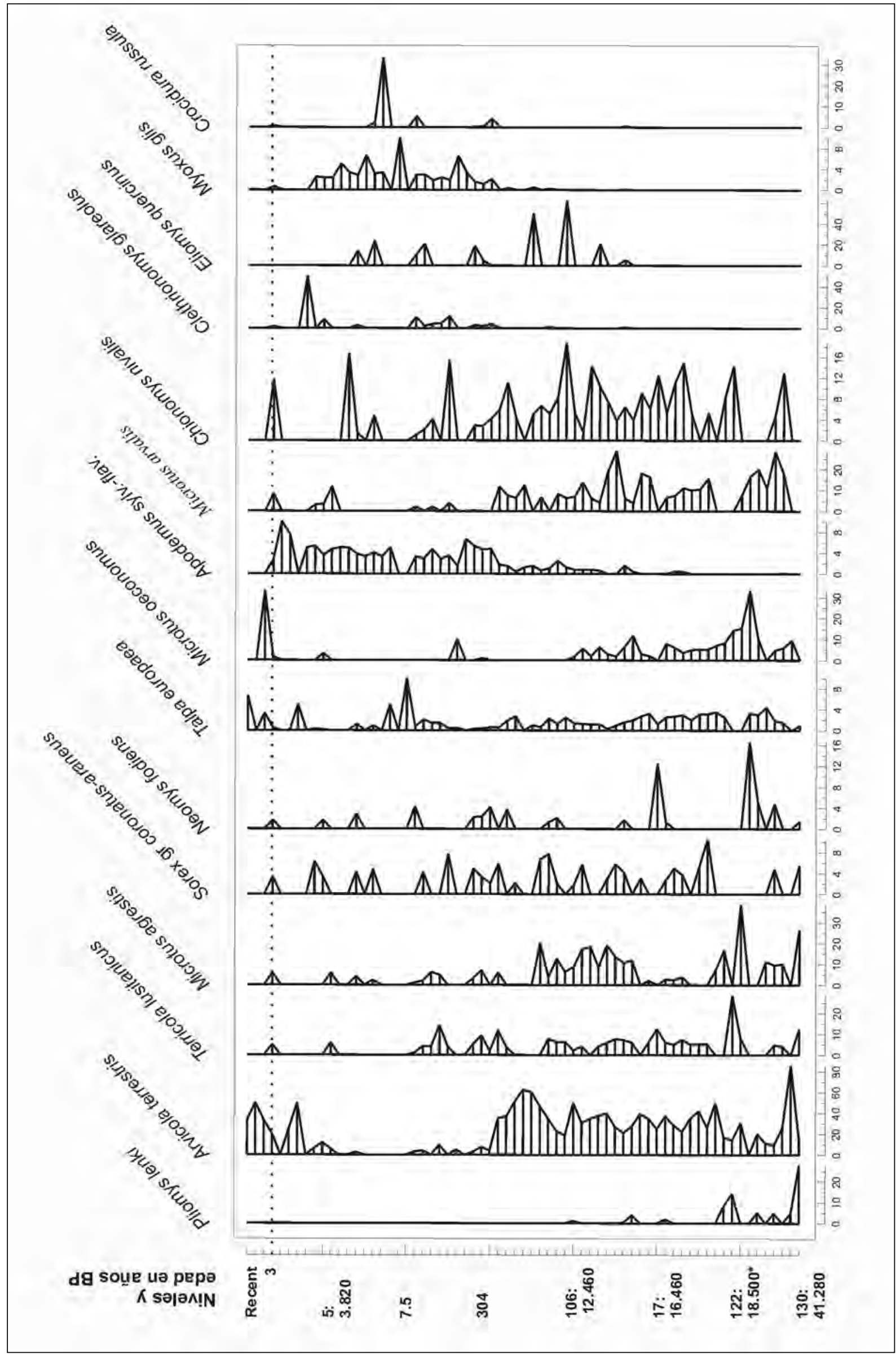


2. La presencia casi continúa en toda la secuencia y hasta la actualidad de A. terrestris y Talpa europaea, y otras que aunque no llegan hasta la actualidad se encuentran en prácticamente todos los niveles como las especies de los géneros Terricola y Microtus.

3. El elevado número de especies de arvicolinos frente a múridos en comparación con otros yacimientos del Holoceno de la Cornisa Cantábrica.

\section{EVOLUCIÓN DEL CLIMA Y DEL PAISAJE}

La mayoría de los pequeños mamíferos del Mirón tienen representantes actuales que viven en el norte de España y son típicos de la "España eurosiberiana", región climática caracterizada por su carácter atlántico, generalmente más húmedo que el de la "España mediterránea". Tomando las propuestas de los distintos autores (Chaline et al., 1999; Cuenca-Bescós et al., 2005) hacemos una clasificación de las especies por su hábitat óptimo. En una primera aproximación y de forma general podemos decir que hay siete grupos distintos de pequeños mamíferos en función del hábitat:

1. Especies de bosque: Eliomys quercinus, Myoxus glis, Apodemus sylvaticus, A. flavicollis y Clethrionomys glareolus

2. Especies de medios abiertos, que pueden ser separados en dos tipos, las de prado húmedo: las del género Sorex, Arvicola terrestris, Terricola lusitanicus y Talpa europaea

3. y las especies de prado seco: Crocidura russula, Microtus agrestis y $M$. arvalis

4. Masas de agua, turberas y prados encharcados: $M i$ crotus oeconomus, Neomys fodiens, A. sapidus

5. Alpinas: Chionomys nivalis y ¿Pliomys lenki?

6. Generalistas: Mustela nivalis

7. Hipogeos: Miniopterus schreibersii y las especies de Myotis, al menos en época de cría

Esta clasificación carece de límites netos pues taxones de bosque pueden encontrarse en bordes de prados secos con abundante vegetación arbustiva (Eliomys, Apodemus) y los de masas de agua pueden adaptarse a prados húmedos (Arvicola). Por otra parte, las especies fósiles no tienen porqué tener los mismos requerimientos ecológicos que sus representantes actuales por lo que su distribución y relación con el hábitat actual puede ser un efecto biogeográfico. Esta clasificación es sólo una aproximación a la evolución paleoambiental de la secuencia Cuaternaria del Mirón con pequeños mamíferos (Fig. 13):

1. El agua de forma permanente está presente en casi todos los niveles salvo en los niveles Mesolíticos, Neolíticos y Calcolíticos. Esta disminución del agua coincide sin embargo con un aumento del bosque. Esto puede estar relacionado con el óptimo climático del Holoceno, un clima más mediterráneo y por tanto, más seco en los períodos estivales.

2. Los prados están siempre presentes aunque en el Paleolítico superior (por datación del $\mathrm{C}^{14}$, equivalente al Gravetiense) se reduce, coincidiendo con un aumento importante de las especies acuáticas. Aunque en la figura 13 no se han separado los dos ambiente, el prado seco está peor representado que el húmedo.

3. Los roquedos sin vegetación tienen representación en toda la secuencia. El incremento del roquedo del nivel Musteriense está ligado al de Pliomys (Fig. 13).

4. El bosque, prácticamente ausente durante el Paleolítico superior hasta el Aziliense, es decir, durante el estadio isotópico MIS 2, conocido también como última glaciación Würm, o Würm IV. Durante el llamado último máximo glaciar (UMG), que coincide con el Solutrense, se registra el valor más bajo del bosque en la secuencia (en el Musteriense también pero aún quedan muchas muestra por estudiar como para poder llegar a una conclusión. Se recupera notablemente a partir de Mesolítico (Óptimo climático del Holoceno) para volver a disminuir hacia el final del Bronce (Fig. 13).

\section{CORRELACIÓN CON LOS DATOS POLÍNICOS Y GEOMORFOLÓGICOS}

El clima durante los últimos 40.000 años en el norte de Iberia es conocido principalmente gracias a los análisis polínicos, al estudio de los testigos de hielo, al aporte de los iceberg (Heinrich, 1988; Sánchez Goñi et al., 2000; Sánchez Goñi \& d'Errico, 2005), así como a la evolución de la geomorfología glaciar y climática en la Península Ibérica (Gutiérrez Elorza \& Peña, 1998; Gutiérrez Elorza \& Sesé Martínez, 2001; García-Ruiz et al., 2003). La sucesión de la vegetación durante el Holoceno se divide en tres fases (Sánchez Goñi et al., 2000):

Figura 12. Distribución cuantitativa (en porcentajes) de los pequeños mamíferos de la secuencia del Mirón. Los números de la base indican el \% de cada especie con respecto al total de especies en cada nivel. Se han omitido las especies representadas por un solo individuo en un único nivel. También se han eliminado los Chiroptera y Lagomorpha. El orden de las especies sigue el de su primera aparición (FAD) en la secuencia.

Quantitative distribution (in percentages) of the small mammals from the El Miron sequence. The numbers at the bottom indicate \%, in Minimum Number of Individuals. In this analisys we do not consider the species represented by one individual only at one level, and also Chiroptera and Lagomorpha. The order of the species, from left to rigth follows that of its first appearance data $(F A D)$ in the sequence. 
Distribución por hábitats de los pequeños mamíferos cuaternarios de la Cueva de EI Miron

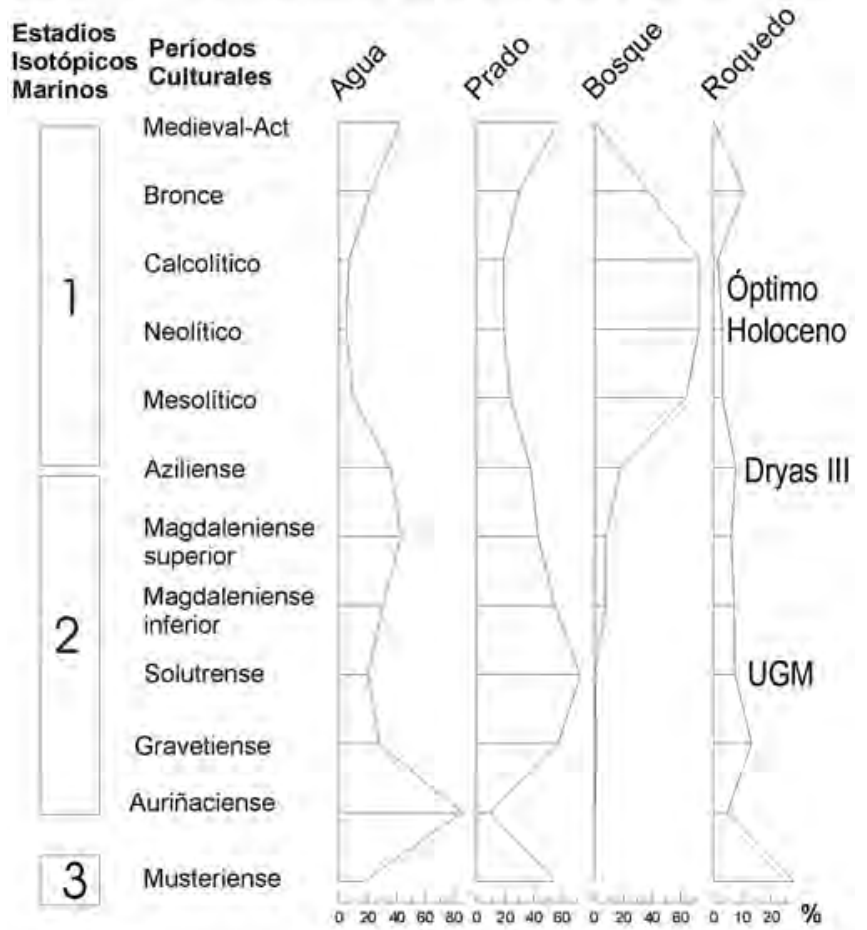

Figura 13. Distribución cuantitativa de los pequeños mamíferos de la secuencia del Mirón agrupados por hábitat. En la primera columna de la derecha figuran los estadios isotópicos marinos (MIS), correlacionados con los niveles estratigráficos y períodos culturales por las dataciones de Carbono 14 (Straus \& González Morales, 2003, 2007). En la segunda columna, los mismos niveles estratigráficos de la Tabla 2, están agrupados por su contenido arqueológico y período cultural. A la izquierda se han representado los principales eventos climáticos del final del cuaternario: UMG, el último máximo glaciar y el período frío del final del Pleistoceno superior, el Dryas III. Obsérvese que en el UMG, y desde el final del MIS 3 faltan las especies de bosque, y el prado, que indica dominio de medios abiertos alcanza su valor máximo en el UMG.

Quantitative distribution of the small mammals of the El Mirón sequence grouped by habitat (Agua =Water; Prado=Meadow; Bosque $=$ Woodland, Roquedo=rocky hills, caves, bare land). In the first column at the left there are the Marine Isotopic Stages (MIS), correlated by radiocarbon data (Straus \& González. Morales, 2003, 2007). In the second column, the same stratigraphic levels of Table 2, grouped by its archeological content and cultural period. At the rigth there is a correlation with the main climatic events of the end of the Quaternary: UMG is the Last Glacial Maximum, the Dryas III is the last cold stage of the end of the Late Pleistocene and Optimo Holoceno is the Climatic Holocene Optimum of the first part of the Holocene. Note that in the UMG as well as from the end of the MIS 3 on, the species that represent the woodland dessapear and the meadows have their maximum values.
Fase a: comienzos del Holoceno, cálida, mediterránea, boscosa (roble y quejigo)

Fase b: fase húmeda caracterizada por el aumento de los helechos

Fase c: disminución importante del bosque, aumento de los brezos (Ericáceas) y fluctuaciones de humedad, que se mantiene aunque algo menos que en la fase anterior. La desaparición del olivo indica condiciones frías.

En relación con la evolución holocena de los pequeños mamíferos del Mirón (Figs. 12 y 13) podemos decir que la fase mediterránea y boscosa también se detecta, con el aumento de las especies de bosque. La fase húmeda es difícil de caracterizar a esta escala. La fase fría se correlaciona con la disminución del bosque, aumento del roquedo, agua, y condiciones abiertas, de prado.

Al final del Pleistoceno el período frío del Dryas III (Aziliense) se correlaciona con un retroceso del bosque y un aumento de las especies de medios abiertos.

El avance de los glaciares y el retroceso de la línea de costa pueden estar en relación con la expansión de las especies de carácter alpino.

\section{CONCLUSIONES}

Tras más de tres décadas de estudio de los pequeños mamíferos en yacimientos pleistocenos y holocenos de la Cornisa Cantábrica, podemos afirmar que éstos proporcionan una información significativa sobre los cambios climáticos y medioambientales ocurridos durante los últimos 50.000 años BP Para llegar a esta conclusión asumimos que los pequeños mamíferos son una parte importante de los ecosistemas terrestres y forman parte de la dieta de numerosos predadores. Su pequeño tamaño los excluye en general como componentes de la dieta humana (al menos durante el Pleistoceno superior y Holoceno inicial) por lo que su presencia en los yacimientos arqueológicos se debe a otros factores de acumulación; aunque no se descarta el comensalismo ocasional y la utilización, también ocasional de su piel o como alimento.

La cueva del Mirón está rellena por sedimentos que datan desde los 41.000 años BP hasta la actualidad, en una secuencia bastante completa, dividida en cerca de 100 niveles arqueológicos o tallas la mayoría de ellos ricos en restos de pequeños mamíferos fósiles. En esta secuencia se han estudiado un total de 721 muestras que han permitido determinar 26 especies de pequeños mamíferos basándonos en un total de 3.403 restos craneales. Hay además cerca de

Figura 14. Expresión de la Mediterraneidad y su evolución en la secuencia del Mirón en función de la proporción de los Arvicolinos frente a los Murinos+Glíridos. "Mediterraneity" and its evolution in the sequence of El Mirón based on the ratio between Arvicolinae and Murinae+Gliridae. 

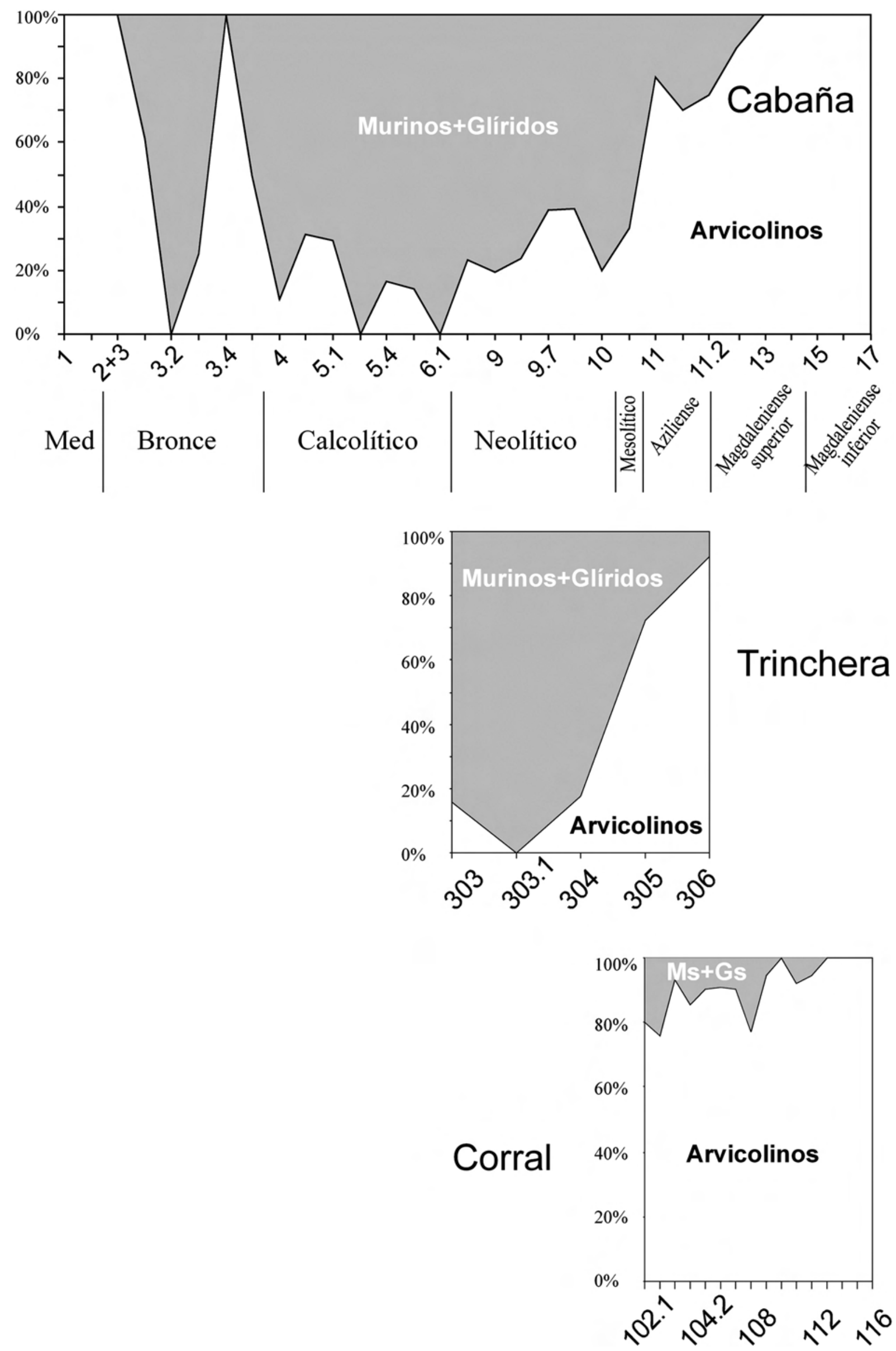
100.000 restos óseos de pequeños mamíferos, aves, anfibios, reptiles y peces que están todavía por identificar.

La fauna fósil del Pleistoceno y Holoceno de la cueva del Mirón representa cerca del $90 \%$ de los pequeños mamíferos actuales de la Cornisa Cantábrica, descontando los quirópteros y los introducidos recientemente por el hombre.

La distribución estratigráfica de los microvertebrados del Mirón es variable según las especies; en general se distribuyen a lo largo de la secuencia con variaciones más o menos importantes en el número de individuos que hay en cada nivel. Las excepciones son: Pliomys lenki que se extingue en el Magdaleniense y coincidiendo con la extinción de $P$. lenki, con un ligero solapamiento en el caso de Eliomys quercinus, aparecen las especies ligadas al bosque. Otras especies tienen una presencia esporádica, a veces un solo registro en toda la secuencia.

Coincidiendo con la aparición de las especies de bosque disminuyen las de medios abiertos, los arvicolinos, y entra también la musaraña de dientes blancos, de carácter mediterráneo. El aumento del bosque, basándonos en el incremento de especies ligadas a este medio, coincide más o menos con el llamado Óptimo Holoceno en el que subieron las temperaturas, antes del declive de temperatura del final del Bronce, cuando hay un incremento de los arvicolinos de medios fríos y húmedos, dato que podría correlacionarse con la pequeña edad del hielo del Bronce. Es notable la persistencia de M. oeconomus y Chionomys nivalis hasta prácticamente el final del Holoceno, aunque ambas especies faltan en la actualidad en la zona costera.

La agrupación de las especies de pequeños mamíferos en función de su hábitat óptimo permite concluir que los cambios paleoambientales y climáticos ocurridos en los últimos 41.000 años BP en esta región de Cantabria son importantes: durante el Würm final (MIS 2) prácticamente no hay bosques mientras que al comienzo del Holoceno (MIS 1) éste se desarrolla notablemente.

Finalmente podemos resumir que:

El estudio de la distribución bioestratigráfica, la composición de las asociaciones y la conservación (tafonomía) de los pequeños mamíferos del Mirón nos permite deducir que las asociaciones de la microfauna de los niveles del final del Pleistoceno y del Holoceno de la Cueva del Mirón reflejan la composición y evolución de las faunas circundantes y por lo tanto son útiles tanto en la reconstrucción paleoclimática como ambiental de los alrededores de la misma.

No parece haber habido una ocupación humana continua durante el Holoceno en El Mirón ya que las especies comensales habrían proliferado en todos los niveles. A favor de esta observación hay que destacar también la alta diversidad de especies en todos los niveles salvo en el actual lo que indica una ocupación importante de las rapaces causantes de la acumulación de pequeños vertebrados, incompatible con el hombre.
La distribución de roedores, insectívoros, quirópteros, conejos y pequeños carnívoros a lo largo de la secuencia El Mirón muestra que hay importantes cambios climáticos en los últimos 41.000 años BP que se reflejan en el aumento/disminución de las especies mediterráneas con respecto a las eurosiberianas.

La entrada de los múridos modernos, comensales del hombre, es más tardía en la Cornisa Cantábrica que en el sur y centro de España.

El Mirón registra la última aparición de la especie Pliomys lenki en Europa.

\section{AGRADECIMIENTOS}

Agradezco las discusiones con Juan Manuel López-García y Angel Hernández. Al equipo de excavación del Mirón. Parte del material de comparación proviene de: Instituto Pirenaico de Ecología de Zaragoza (Dr. Juan Pablo Martínez Rica), Universidad de Zaragoza, Museo Nacional de Ciencias Naturales (Dra. J. Barreiro) y CAS (Burgos). La excavación de la Cueva del Mirón, dirigida por LGS y MGM cuenta con el apoyo económico de la Fundación M. Botín, Gobierno de Cantabria, Ministerio de Educación y Ciencia de España, US National Science Foundation, National Geographic Society, University of New Mexico y L.S.B. Leakey Foundation, así como la ayuda logística de la Villa de Ramales de la Victoria en Cantabria. La investigación de G.C.-B. se enmarca dentro de los proyectos $\mathrm{PO}$ BOS 2003-8938 y CGL2006-13532-C03-02 y Grupos Consolidados 2007 Gobierno de Aragón, además de la Ayuda Salvador de Madariaga (M.E.C) durante su estancia en la Universidad de Nuevo Mexico.

\section{BIBLIOGRAFÍA}

Abbassi, M., Desclaux, E., Marquet, J. C. \& Chaline, J. 1998. Répartition et Évolution des Arvicola Lacépède, 1799 (Rodentia, Mammalia) au cours du Pleistocene Moyen et supérieur en France et en Ligurie. Quaternaire, 9, 105-116.

Agustí, J. \& Galobart, A. 1986. La sucesión de micromamíferos en el complejo cárstico de Casablanca (Almenara, Castellón: problemática biogeográfica). Paleontologia $i$ evolució, 20, 57-62.

Agustí, J., Alcalde, B., Burjachs, F., Juan-Muns, N., Oller, J., Ros, M.T. \& Rueda, J.M. 1987. El yacimiento del Paleolítico Medio de la Cueva 120 (La Carrotxa, Cataluña). Primeros resultados. VII Reunión sobre el Cuaternario AEQUA, 1, 1-4.

Alcalde Gurt, G. 1982. Presènsia interessant de Pliomys lenki i de Microtus oeconomus en el reompliment de la cova dels Ermitons (La Garrotxa, Girona). Acta Geológica Hispánica, 17, 281-282.

Alcalde, G. 1986. Les faunes de rongeurs du Pléistocène supérieur et de l'Holocène de Catalogne (Espagne) et leurs significations palèoécologiques et palèoclimatiques. Paris, Diplôme E.P.H.E., 120 pp. (inédito). 
Alcalde, G. 1988. Els rosegadors en l'Arqueología Catalana. Cota Zero, 4, 65-69.

Alcalde, G. \& Brunet, P. 1985. Contribució al coneixement del medi i el clima durant el Pleistocè superior i l'holocè a Catalunya, amb l'aplicació de l'anàlisis factorial de les correspondències a les associacions de rosegadors. Paleontología i Evolució, 19, 49 -55.

Alcántara de la Fuente, M. 1992. Distribución y preferencias de hábitat de los micromamíferos (Insectivora y Rodentia) de la Sierra de Guadarrama. Tesis Doctoral. Universidad Complutense de Madrid, 263 pp. (inédita).

Alegre, J. \& Hernández, A. 1990. Datos sobre la distribución de algunas especies de micromamíferos en la zona montañosa de la Provincia de León. Tierras de León, 77-78, 131-152.

Alegre, J., Hernández, A., Purroy, F. \& Sánchez, A. 1989. Distribución latitudinal y patrones de afinidad trófica geográfica de la lechuza común (Tyto alba) en León. Ardeola, 36, 41-54.

Altuna, J. 1970. Fauna de Mamíferos del Yacimiento Prehistórico de Aitzbitarte IV (Rentería, Guipúzcoa). Munibe, 22, 3-41.

Altuna, J. 1972. Fauna de mamíferos de los yacimientos prehistóricos de Guipúzcoa. Munibe, 24, 1-464.

Altuna, J. 1981. Restos óseos del yacimiento prehistórico del Rascaño (Santander). In: El Paleolítico Superior de la cueva del Rascaño (Eds. J. Echegaray \& I. Barandiarán). Museo de Altamira Monografías, 3, 221-269.

Altuna, J. 1986. The mammalia faunas from the prehistoric site of La Riera. In: La Riera Cave (Eds. L. G. Straus \& G.A. Clark). Anthropological Research Papers, 36, 237-274.

Altuna, J., Cuenca-Bescós, G., Elorza, M., García, J.C., Lobo, J., Mariezkurrena, K., Pérez, M., Sanchiz, B., González, M. \& Guy, L. 2004. Post - pleistocene faunas from the archaelogical site of El Miron cave (Ramales de la Victoria, Cantabria, Spain). In: Miscelánea en homenaje a Emiliano Aguirre (Eds. E. Baquedano \& S. Rubio Jara). Zona Arqueológica, 4 (2), 41 -49.

Álvarez, M. T., Morales, A. \& Sesé, C. 1992. Mamíferos del yacimiento del Pleistoceno Superior de Cueva Millán (Burgos, España). Estudios geológicos, 48, 193-204.

Andrews, P. 1990. Owls, Caves and Fossils. The Natural History Museum Publications, London, 1-231.

Arribas, A. 1994. El yacimiento mesopleistoceno de Villacastín (Segovia, España. Geología y Paleontología de micromamíferos. Boletín Geológico y Minero, 105, 146-166.

Arrizabalaga i Blanch, A, Montagud i Blas, E. \& Gosálbez i Noguera, J. 1986. Introducció a la Biologia i Zoogeografia dels petits maífers (Insectivors i Rosegadors) del Montseny (Catalunya). Papers de Treball, Generalitat de Catalunya, CIRIT, 1-113.

Arrizabalaga, A., Altuna, J., Areso, P., Elorza, M., García, M., Iriarte, M.J., Mariezkurrena, K., Mujika, J., Pemán, E., Tarriño, A., Uriz, A., Viera, L. \& Straus, L.G. 2003. The Initial Upper Paleolithic in Northern Iberia: New Evidence from Labeko Koba. Current Anthropology, 44, 413-421.
Baena, J., Carrión, E., Ruiz, B., Ellwood, B., Sesé, C., Yravedra, J., Jordá, J., Uzquiano, P., Velázquez, R., Manzano, I., Sánchez-Marco, A. \& Hernández, F. 2005. Paleoecología y comportamiento humano durante el Pleistoceno Superior en la comarca de Liébana: La secuencia de la Cueva de El Esquilleu (Occidente de Cantabria, España). Museo de Altamira. Monografías, 20, 461-487.

Bartolomei, G., Chaline, J., Fejfar, O., Jánossy, D., Jeannet, M., Koenigswald, W. \& Kowalski, K., 1975. Pliomys lenki (Heller 1930) (Rodentia, Mammalia) in Europe. Acta Zoologica Cracoviensa, 20, 393-467.

Blanco, J. C. 1998a. Mamíferos de España I. Insectívoros, Quirópteros, Primates y Carnívoros de la Península Ibérica, Baleares y Canarias. Editorial Planeta, Barcelona, 464 pp.

Blanco, J. C. 1998b. Mamíferos de España II. Cetáceos, Artiodáctilos, Roedores y Lagomorfos de la Península Ibérica, Baleares y Canarias. Editorial Planeta, Barcelona, $464 \mathrm{pp}$.

Borghi, C. E., Giannoni, S. M. \& Martínez Rica, J. P. 1990. Soil removed by voles of the genus Pitymys in the Spanish Pyrenees. Pirineos, 136, 3-18.

Brunet-Lecomte, P. 1991. Répartition géographique des campagnols du genre Microtus (Arvicolidae, Rodentia) dans le nord-ouest ibérique. Arquivos do Museu Bocage, 2, 11-29.

Brunet-Lecomte, P. \& Chaline, J. 1990. Relations phylogénétiques et évolution des campagnols souterrains d'Europe (Terricola, Arvicolidae, Rodentia). Comptes Rendues Academie des Sciences, Paris, 311, Sér. II, 745-750.

Brunet-Lecomte, P. \& Chaline, J. 1993. Mise au point sur Microtus (Terricola) pyrenaicus gerbei (Gerbe, 1879) (Rodentia, Arvicolidae). Mammalia, 571, 139-142.

Brunet-Lecomte, P. \& Delibes, M. 1984. Alimentación de la lechuza común Tyto alba en la cuenca del Duero, España. Doñana, Acta Vertebrata, 11, 213-229.

Brunet-Lecomte, P., Brochet, G., Chaline, J. \& Delibes, M. 1987. Morphologie dentaire comparée de Pitymys lusitanicus et $P$. duodecimcostatus (Arvicolidae, Rodentia) dans le nord-ouest de l'Espagne. Mammalia, 51, 145-158.

Cabrera Millet, M., Britton-Davidian, J. \& Orsini, P. 1982. Génétique biochimique comparée de Microtus cabrerae Thomas, 1906 et de trois autres espèces d'Arvicolidae méditerranéens. Mammalia, 46, 381-388.

Campos Marcos, M. A., Balmori Martínez, A., Canales Basabe, F., Onrubia Baticón, A. \& Sáenz de Buruaga Tomillo, A. 2003. Estudio Mastozoológico del entorno de Salburua (Vitoria-Gasteiz). Informe Inédito Centro de Estudios Ambientales de Vitoria-Gasteiz, Consultora de Recursos Naturales, S.L., 178 pp.

Carvalho, J. C. \& Gomes, P. 2004. Feeding resource partitioning among four sympatric carnivores in the PenedaGeres National Park (Portugal). Journal of Zoology, 263 275-283.

Casteig, F. J. \& Escala, C. 1988. Morfometría de Sorex coronatus Millet, 1828 (Insectivora, Mammalia) en Navarra. Miscelánea Zoológica, 12, 309-317.

Castien, E. \& Gosàlbez, J. 1992. Distribución geográfica y hábitats ocupados por Galemys pyrenaicus (Geoffroy, 
1911) (Insectivora: Talpidae) en los Pirineos occidentales. Doñana, Acta Vertebrata, 19, 37-44.

Chaline, J. 1972. Les rongeurs du Würmien II de la grotte de 1'Hortus (Valflaunès, Hérault). Etudes quaternaires, 1, 233-240.

Chaline, J. 1975. Evolution et rapports phyletiques des campagnols (Arvicolidae, Rodentia) apparentés à Dolomys et Pliomys dans l'hemisphère nord. Comptes Rendues Academie des Sciences, Paris, D, 281, 33-36.

Chaline, J. \& Marquet, J.-C. 1976. Les conséquences stratigraphiques de la persistance en France dans le Würm ancien del rongeurs reliques Pliomys lenki et Allocricetus bursae (Rodentia). Comptes Rendues Academie des Sciences, Paris, 282, 1941-1942.

Chaline, J., Brunet-Lecomte, P., Montuire, S., Viriot, L. \& Curant, F. 1999. Anatomy of the arvicoline radiation (Rodentia): palaeogeographical, palaeoecological history and evolutionary data. Annales Zoologici Fennici, 36, 239-267.

Conroy, C.J. \& Cook, J.A. 2000. Molecular Systematics of a Holarctic Rodent (Microtus: Muridae). Journal of Mammalogy, 81, 344-359.

Courty, M.-A. \& Vallverdu, J. 2001. The Microstratigraphic Record of Abrupt Climate Changes in Cave Sediments of the Western Mediterranean. Geoarchaeology: An International Journal, 16, 467-500.

Cuenca-Bescós, G., Canudo, J. I. \& Laplana, C. 1995. Los Arvicólidos (Rodentia, Mammalia) de los niveles inferiores de Gran Dolina (Pleistoceno Inferior, Atapuerca, Burgos, España). Revista Española de Paleontología, 10, 202-218.

Cuenca-Bescós, G., Laplana Conesa, C., Canudo, J. I. \& Arsuaga, J. L. 1997. Small mammals from Sima de los Huesos. Journal of Human Evolution, 33, 175-190.

Cuenca-Bescós, G., Canudo, J. I. \& Laplana, C. 1999. Análisis bioestratigráfico de los roedores del Pleistoceno Medio del yacimiento de Galería (Sierra de Atapuerca, Burgos). Memorias. Arqueología en Castilla y León. Atapuerca: Ocupaciones humanas y paleoecología del yacimiento de Galería, 7, 189-210.

Cuenca-Bescós, G., Rofes, J. \& García-Pimienta, J. C. 2005. Early europeans and environmental change across the Early-Middle Pleistocene transition: small mammalian evidence from Trinchera Dolina cave, Atapuerca, Spain. In: Early-middle Pleistocene transitions: the land-ocean evidence (Eds. M.J. Head \& P.L. Gibbard). Geological Society of London, Special Publication, 247, 277-286.

Cuenca-Bescós, G., González Morales, M., Barco, J. \& Straus, L. 2006. Upper Pleistocene Pliomys lenki (Rodentia, Mammalia) in Iberia: a tale of flickering extinction. Journal of Vertebrate Paleontology, 26, 53A.

Currant, A.P. 1986. The Late Glacial mammal fauna of Gough's Cave, Cheddar, Somerset. Proceedings University of Bristol Speleological Society, 17, 286-304.

Desclaux, E. 1996-1997. Contribution des Micromammifères à la connaissance des paléoenvironnements des chasseurs de la Grotte du Lazaret à Nice. Archéam Cahiers du Cercle d'Histoire et d'Archeologie des Alpes-Maritimes, 4, 7-11.
Eastham, A. 1995. Chapitre 19. La Microfaune. In: Les derniers chasseurs de rennes du Monde Pyrénéen. L'Abri dufaure: un gisement tardiglaciaire en Gascogne (Ed. L. G. Straus). Mémoire Societé Préhistorique de France, 22, 235-245.

Fara, E. 2001. What are Lazarus taxa? Geological Journal, 36, 291-303.

Ferraris, M., Sala, B. \& Scola, V. 1990. The Late Pleistocene fauna with Pliomys lenki from the Ghiacciaia Cave loess (Northern Italy). Quaternary International, 5, 71-79.

Frafjord, K. 2003. Do eagle owls select larger water voles? Fauna norvegica, 23, 42-47.

Furió Bruno, M. 2003. Los Insectivoros (Mammalia) del Pleistoceno Inferior de Fuente Nueva 3 y Barranco León (Orce, Granada). In: El Pleistoceno Inferior de barranco León y Fuente Nueva 3, Orce (Granada) (Coord. J. Agustí, B. Martínez-Navarro \& I. Toro). Arqueología Monografías. Consejería de Cultura de la junta de Andalucía, 147-157.

Galán C. 1997. Fauna de Quirópteros del País Vasco (Bats Fauna from the Basque Country). Munibe, 49, 77-100.

García García, N. 2003. Osos y otros carnívoros de la Sierra de Atapuerca. Fundación Oso de Asturias, Oviedo, 1-570.

García-Perea, R. \& Gisbert, J. 1997. Lista patrón de los mamíferos de la Península Ibérica, Islas Baleares y Canarias. Galemys, 9, 1-38.

Garcia-Ruiz, J.M., Valero-Garcés, B.L., Marti-Bono, C. \& Gonzalez-Samperiz, P. 2003. Asynchroneity of maximum glacier advances in the central Spanish Pyrenees. Journal of Quaternary Science, 181, 61-72.

Giannoni, S. M., Borghi, C. E. \& Martínez Rica, J. P. 1992. New data on the burrowing behaviour of Microtus (Pitymys) duodecimcostatus. Zeitschrift für Säugetierkunde, 57, 23-28.

Giannoni, S. M., Borghi, C. E. \& Martínez Rica, J. P. 1993. Comparing the burrowing behaviour of the Iberian mole voles (Microtus (Terricola) lusitanicus, M. (T.) pyrenaicus and M. (T.) duodecimcostatus). Mammalia, 57, 4, 483-490.

Gil, E. \& Lanchares, E. 1988. Los roedores del yacimiento musteriense de la Cueva de Gabasa (Pirineo Aragonés). Interés paleoecológico. Geogaceta, 3, 5-7.

Gil, E. \& Sesé, C. 1985. Los roedores (Mammalia) del sitio de ocupación Musteriense de la Cueva de los Toros (Teruel). Col-Pa, 40, 41-49.

González-Esteban, J., Villate, I. \& Gosálbez, J. 1994. Requerimientos ambientales de Microtus arvalis asturianus Miller, 1908 (Rodentia, Arvicolidae) en la Península Ibérica. Doñana, Acta Vertebrata, 21, 109-118.

Gosálbez, J. 1993. Utilización de las egagrópilas de rapaces nocturnas en el estudio de los micromamíferos. Boletin SECEM, 2, 22-27.

Guillem, P. 1995a. Paleontología continental: microfauna. En: El Cuaternario del País Valenciano. Asociación Española para el Estudio del Cuaternario y Universitat de València, València, 227-233.

Guillem, P. 1995b. Bioestratigrafía de los micromamíferos (Rodentia, Mammalia) del Pleistoceno Medio, Superior y Holoceno del País Valenciano. Saguntum, 38, 11-18. 
Guillem, P. 1999. Los micromamíferos (Rodentia, Insectivora y Chiroptera) de la Secuencia Holocena de la Cova de les Cendres y Cova Bolumini. II Congrès de Neolític a la Península Ibérica, Saguntum, 2, 31-36.

Guillem, P. 2001. Los micromamíferos y la secuencia climática del Pleistoceno Medio, Pleistoceno Superior y Holoceno, en la fachada central mediterránea. In: De Neandertales a Cromañones. El inicio del poblamiento humano en las tierras valencianas (ed. V. Villaverde). Universitat de València, Valencia, 57-72.

Gutierrez Elorza, M. \& Peña Monné, J.L. 1998. Geomorphology and late Holocene climatic change in Northeastern Spain. Geomorphology, 23, 205-217.

Gutierrez Elorza, M., \& Sesé Martínez, V.H. 2001. Multiple talus flatirons, variations of scarp retreat rates and the evolution of slopes in Almazán Basin (semi-arid central Spain). Geomorphology, 38, 19-29.

Heinrich, H. 1988. Origin and consequences of cycle ice rafting in the northeast Atlantic Ocean during the past 130,000 years. Quaternary Research, 9, 142-152.

Heinrich, W.-D. 1990. Some aspects of evolution and biostratigraphy of Arvicola (Mammalia, Rodentia) in the central european pleistocene. In: International Symposium Evolution, Phylogeny and Biostratigraphy of Arvicolids (Rodentia, Mammalia) (Eds. O. Fejfar \& W.-D. Heinrich). Rohanov, 165-182.

Hernández, A. 2005. Topos en la dieta de zorros rojos en el noroeste de España. Galemys, 17, 87-90.

Hernández, A., Sánchez, A. J. \& Alegre, J. 1987. Datos sobre el régimen alimenticio del Mochuelo común (Athene noctua) y la Lechuza común (Tyto alba) en hábitats esteparios en la cuenca del Duero (León y Zamora, España). I Congreso Internacional de Aves Esteparias, León, 183-192.

Horácek, I. 1976. Review of Quaternary Bats in Czechoslovaquia. Lynx, 18, 35-58.

Indermuhle, A., Stocker, T.F., Joos, F., Fischer, H., Smith, H.J., Wahlen, M., Deck, B., Mastroianni, D., Tschumi, J., Blunier, T., Meyer, R. \& Stauffer, B. 1999. Holocene carbon-cycle dynamics based on $\mathrm{CO}_{2}$ trapped in ice at Taylor Dome, Antarctica. Nature, 398, 121-126.

Iza, J.B., Castien, E., Mendiola, I. \& Peman, E. 1985. Algunos aspectos de la ecología de los micromamíferos del País Vasco. Munibe, 37, 101-110.

Jaarola, M., Martinkova, N., Gunduza, I., Brunho, C., Zima, J., Nadachowski, A., Amori, G., Bulatova, N.S., Chondropoulos, B., Fraguedakis-Tsolis, S., Gonzalez-Esteban, J., Lopez-Fuster, M.J., Kandaurov, A.S., Kefelioglud, H., Mathias, M.L., Villatei, I. \& Searl, J.B. 2004. Molecular phylogeny of the speciose vole genus Microtus (Arvicolinae, Rodentia) inferred from mitochondrial DNA sequences. Molecular Phylogenetics and Evolution, 33, 647-663.

Jammot, D. 1974. Les Insectivores de Cagny (Somme). Soricidae (Insectivora, Mammalia). Bulletin pour l'Association Française du Quaternaire, 41-42, 187-189.

Jeannet, M., Allard, M. \& Juillard, F. 1996. Première decouverte de Galemys pyrenaicus (Insectivora, Desmaninae) dans le Quaternaire français. Revue de Paléobiologie, 15, 205-213.
Jullien, R. 1972. Les chiroptères du Würmien II de la grotte de l'Hortus (Valflaunès, Hérault). Etudes Quaternaires Mémoire. La grotte Moustérienne de l'Hortus, 1, 247-265.

Koenigswald, W. v. \& Kolfschoten, T. v. 1996. The MimomysArvicola boundary and the enamel thickness quotient (SDQ) of Arvicola as stratigraphic markers in the Middle Pleistocene. The early Middle Pleistocene in Europe (Ed. C. Turner). Proceedings of the SEQS Cromer Symosium, 211-226.

Kowalski, K. 1956. Insectivores, bats and rodents from the Early Pleistocene bone breccia of Podlesice near Krocyce (Poland). Acta Palaeontologica Polonica, 4, 331-394.

Krystufek, B. \& Haberl, W. 2001. Dormouse associations in Slovenia - a new approach to an old tradition. Trakya University Journal of Scientific Research, 2, 171-177.

Laplana Conesa C. \& Cuenca-Bescós, G. 1995. Los microvertebrados (anfibios, reptiles y mamíferos) asociados al yacimiento de la Edad del Bronce de La Balsa la Tamariz (Tauste, Zaragoza). Col-Pa, 47, 55-69.

León García, J. 1998. Cantabria Subterránea. Catálogo de las Grandes Cavidades. Diputación Regional de Cantabria, Consejería de Cultura, Santander, 1- 700.

López Antoñanzas, R. \& Cuenca-Bescós, G. 2002. The Gran Dolina Site (Lower to Middle Pleistocene, Atapuerca, Burgos, Spain. New palaeoenvironmental data based on the distribution of small mammals. Palaeogeography, Palaeoclimatology, Palaeoecology, 186, 311-334.

López-Fuster, M. J. \& Ventura, J. 1996. A morphometrical review of the Sorex araneus-arcticus species group from the Iberian Peninsula (Insectivora, Soricidae). Bonner Zoologische Beiträge, 46, 327-337.

López-Fuster, M.J., Ventura, J., García-Perea, R. \& Gisbert, J. 1999. The Sorex araneus group in the northern Iberian System (Spain): a contact zone between $S$. coronatus and S. granarius? Acta Theriologica, 44, 113-122.

López-García, J.M. 2006. Los roedores, insectívoros, quirópteros y anfibios en relación a las ocupaciones humanas del Holoceno inicial de la Cueva del Mirador (Atapuerca, Burgos). Tesis de Licenciatura, Universitat Rovira i Virgili de Tarragona, 122 pp. (inédita).

López-García, J.M. \& Morales Hidalgo, J.I. 2007. Análisis preliminar de los Roedores (Mammalia) del Nivel Nb del Abric Romani (Capellades, Barcelona). Actas del III Encuentro de Jóvenes Investigadores en Paleontología, 95-103.

Luque-Larena, J.J., López, P. \& Gosálbez, J. 2002. Microhabitat use by the snow vole Chionomys nivalis in alpine environments reflects rock-dwelling preferences. Canadian Journal of Zoology, 80, 36-41.

Marín Arroyo, A. B. 2007. La fauna de Mamíferos en el Cantábrico Oriental durante el Magdaleniense y Aziliense: Nuevos Enfoques y Líneas de Investigación Arqueozoológicas. Tesis Doctoral, Universidad de Cantabria, 684 pp. (inédita).

Marks, A.E., Brugal, J.-Ph., Chabai, V.P., Monigal, K., Goldberg, P., Hockett, B., Peman, E., Elorza, M. \& Mallol, C. 2002. Le gisement pléistocène moyen de Galeria Pesada (Estrémadure, Portugal). Premiers résultats. Paléo, 14, 77-100. 
Marquet, J.C. 1989. Paleoenvironnement et Chronologie des sites du domaine Atlantique français d'age Pleistocene moyen et supèrieur d'apres l'étude des rongeurs. Thèse, Université de Bourgogne, 637 pp. (inédita).

Marquet, J.C. 2001. Les rongeurs de la Grotte du Sanglier. (Reilhac, Lot). Préhistoire du Sud-Ouest, 4, 175-182.

Martínez-Cortizas, A., Pontevedra-Pombal, X., Garcia-Rodeja, E., Novoa-Muñoz, J.C. \& Shotyk, W. 1999. Mercury in a Spanish peat bog: Archive of climate change and atmospheric metal deposition. Science, 284, 939-942.

Maul, L. 1990. Üeberblick über die unterpleistozänen Kleinsäugerfaunen Europas. Quartärpaläontologie, 8, 153-191.

Maul, L. 2001. The transition from hypsodonty to hypselodonty in the Mimomys savini-Arvicola lineage. Lynx, 32, 247-253.

Maul, L. \& Markova, A. 2007. Similarity and regional differences in Quaternary arvicolid evolution in Central and Eastern Europe. Quaternary International, 160, 81-99.

Meulen, A. van der 1973. Middle Pleistocene smaller Mammals from the Monte Peglia (Orvieto, Italy), with Special Reference to the Phylogeny of Microtus (Arvicolidae, Rodentia). Quaternaria, 17, 1-144.

Mitchell-Jones, A. J., Amori, G., Bogdanowicz, W., Krystufek, B., Reijnders, P. J. H., Spitzenberger, F., Strubbe, M., Thissen, J. B. M., Vohralík, V. \& Zima, J. (Eds.) 1999. The Atlas of European Mammals. Societas Europaea Mammalogica. Poyser Natural History Series, Academic Press, London, 484 pp.

Morales Muñiz, A. 1986. Análisis de la fauna de vertebrados recuperada en las sepulturas del poblado del Bronce del Cerro de La Encantada (Provincia de Ciudad Real). Oretvm, 2, 159-196.

Morales Muñiz, A. \& Rodríguez, J. 1997. Black rats (Rattus rattus) from medieval Mertola (Baixo Alentejo, Portugal). Journal of Zoololgy London, 241, 623-642.

Morales Muñiz, A., Cereijo Pecharroman, M. A., Hernández Carrasquilla, F. \& Lettow-Vorbeck, L.V. 1997. Of Mice and Sparrows: Commensal Faunas from the Iberian Iron Age in the Duero Valley (Central Spain). International Journal of Osteoarchaeology, 5, 127-138.

Moreno, E. \& Rey, J. M. 1980. La alimentación de la lechuza común (Tyto alba) en la provincia de Huesca y su aplicación a la zoogeografía de los micromamíferos: insectívoros y roedores. II Jornadas Iberoamericanas de Zoología y Conservación de Vertebrados. Cáceres, 235-236.

Moreno, S. 2002. Lirón Careto Eliomys quercinus (Linnaeus, 1766). Galemys, 14, 1-16.

Nadachowski, A. 1982. Late Quaternary rodents of Poland with special reference to morphotype dentition analysis of voles. Panstwowe Wydawnictwo Naukowe, Warszawa-Kraków, 1-108.

Nadachowski, A. 1990. Lower Pleistocene Rodents of Poland: faunal succession and biostratigraphy. Quartärpaläontologie, 8, 215-223.

Niethammer, J. \& Krapp, F. 1982. Handbuch der saugertiere europas. Band I: Nagetiere I. (Muridae). Akademische Verlagsgesellschaft, Wiesbaden, 1-649.
Nores, C. 1979. Comparación del régimen alimenticio de Strix aluco y Tyto alba en la Costa Oriental Asturiana. Revista Facultad Ciencias, Universidad Oviedo, 20-21, 189-194.

Nores, C. 1988. Diferenciación biométrica de Apodemus sylvaticus y Apodemus flavicollis en la Cordillera Cantábrica. Primeros resultados. Revista Biología, Universidad de Oviedo, 6, 109-116.

Nores, C. 2003. Ratón espiguero Micromys minutus (Pallas, 1771). Galemys, 15, 3-10.

Oms, O., Agustí, J., Gabàs, M. \& Anadón, P. 2000. Lithostratigraphical correlation of micromammal sites and biostratigraphy of the Upper Pliocene to Lower Pleistocene in the Northeast Guadix-Baza Basin (southern Spain). Journal of Quaternary Science, 15, 43-50.

Palacios, F. 1988. Nuevos datos acerca de la distribución del Topillo campesino, Microtus arvalis Pallas 1778 en la Península Ibérica. Doñana, Acta Vertebrata, 15, 169-171.

Palomo, L. J. \& Gisbert, J. 2002. Atlas de los mamíferos terrestres de España. Dirección General de Conservación de la Naturaleza-SECEM-SECEMU, Madrid, 1-564.

Paunovic, M. \& Rabeder, G. 1996. Die altpleistozänen Kleinsäugerfaunen Razvodje und Tatinja draga in SüdKroatien. Beiträge zur Paläontologie, 21, 69-84.

Pemán, E. 1983. Biometría y sistemática del género Neomys Kaup, 1771 (Mammalia, Insectivora) del País Vasco. Munibe, 35, 115-148.

Pemán, E. 1985. Aspectos climáticos y ecológicos de los Micromamíferos del yacimiento de Erralla. Munibe, 37, 49-57.

Pemán, E. 1987. Los micromamíferos del yacimiento de Iruaxpe I (Guipúzcoa). Munibe, 39, 85-86.

Pemán, E. 1988. Los micromamíferos de Urtao II (Oñati, Guipúzcoa). Munibe, 41, 77-78.

Pemán, E. 1990a. Los micromamíferos de la cueva de Amalda y su significado. Comentarios sobre Pliomys lenki (Heller, 1930) (Rodentia, Mammalia). In: La Cueva de Amalda (Zestoa, Pais Vasco) Ocupaciones paleolíticas y postpaleoliticas (Eds J. Altuna, A. Baldeón \& K. Mariezkurrena). Colección Barandiarán, 4, 225-238.

Pemán, E. 1990b. Los micromamíferos en el Pleistoceno Superior del País Vasco. Munibe, 42, 259-262.

Pemán, E. 2000. Los micromamíferos de Labeko Koba (Arrasate, País Vasco). In: Labeko Koba (País Vasco). Hienas y Humanos en los albores del Paleolítico superior (Eds. A. Arrizabalaga \& J. Altuna). Munibe, 52, 183-185.

Peña-Chocarro, L., Zapata, L., Iriarte, M.J., González Morales, M. \& Straus, L.G. 2005. The oldest agriculture in northern Atlantic Spain: new evidence from El Mirón Cave (Ramales de la Visctoria, Cantabria). Journal of Archaeological Science, 32, 579-587.

Peyre, A. 1956. Ecologie et biogeographie du desman (Galemys pyrenaicus G.) dans les Pyrénées francaises. Mammalia, 20, 405-418.

Piertney, S.B., Stewart, W.A., Lambin, X., Telfer, S., Aars, J. \& Dallas, J.F. 2005. Phylogeographic structure and postglacial evolutionary history of water voles (Arvicola terrestris) in the United Kingdom. Molecular Ecology, 14, 1435-1444. 
Pokines, J.T. 1998. The Paleoecology of Lower Magdalenian Cantabrian Spain. Bar International Series, 713, 1-189.

Pokines, J.T. 2000. Microfaunal research design in the Cantabrian Spanish Paleolithic. Journal of Anthropological Research, 56, 95-112.

Rekovets, L. \& Nadachowski, A. 1995. Pleistocene Voles (Arvicolidae) of the Ukraine. Paleontologia $i$ evolució, 28-29, 145-245.

Repenning, C.A. 1968. Mandibular musculature and the origin of the subfamily Arvicolinae (Rodentia). Acta Zoologica Cracoviensia, 13, 29-72.

Rey, J. M. \& Landin, A. 1973. Sobre la presencia de Crocidura suaveolens en el sur de Andalucía (Mammalia, Insectivora). Boletín de la Real Sociedad Española Historia Natural (Biología), 71, 9-16.

Riquelme Cantal, J.A. \& Morales Muñiz, A. 1997. A Porcupine find from Roman Africa with a review of Archaeological data from circummediterranean sites. Archaeofauna, 6, 91-95.

Rofes, J. \& Cuenca-Bescós, G. 2006. First evidence of the Soricidae (Mammalia) Asoriculus gibberodon (Petényi, 1864 ) in the Pleistocene of North Iberia. Rivista Italiana di Paleontologia e Stratigrafia, 112, 301-315.

Ruiz, A. \& Camacho, I. 1973. Datos sobre la alimentación de Bubo bubo y determinación de micromamíferos en Sierra Nevada mediante egagrópilas. Cuadernos Ciencias Biológicas, 2, 57-61.

Ruiz Bustos, A. 1988. Presencia de caracteres mimomianos en Arvicola mosbachensis, Schmictgen, 1911, del yacimiento de Cúllar de Baza-I. Consideraciones sobre su origen. II Congreso Geológico de España. Comunicaciones, Granada, 1, 325-328.

Ruiz Bustos, A. 2000. Estudio paleoecológico de los sedimentos con presencia del hombre de neandertal en la cueva de la Carihuela (Piñar, Granada). In: Síntesis ambiental del Würm mediterráneo en la Cordillera Bética. Edita Ayuntamiento de Piñar, 1-91.

Ruiz Bustos, A. 2004. Micromamíferos y Bioestratigrafía. Laboratorio de Micromamíferos del Instituto Andaluz de Ciencias de la tierra CSIC- Universidad de Granada, 2, 1-141.

Ruiz Bustos, A. \& Sesé, C. 1985. Evolución de los géneros Mimomys, Arvicola y Allophaiomys (Arvicolidae, Rodentia, Mammalia) en el Plioceno y Pleistoceno de la Península Ibérica. Estudios geológicos, 41, 99-104.

Rzebik-Kowalska, B. 1994. Pliocene and Quaternary Insectivora (Mammalia) of Poland. Acta Zoologica Cracoviensa, 37, 77-136.

Rzebik-Kowalska, B. 1998. Fossil History of Shrews in Europe. In: Evolution of Shrews. Mammal Research Institute Polish Academy of Sciences (Eds. J.M. Wójcik \& M. Wolsan), 2, 23-92.

Sánchez Goñi, M. F. \& d'Errico, F. 2005. La historia de la vegetación y el clima del último ciclo climático (OIS5OIS1, 140.000-10.000 años BP) en la Península Ibérica y su posible impacto sobre los grupos paleolíticos. Museo y Centro de Investigación de Altamira Monografías, 20 , 115-129.
Sánchez Goñi, M.F., Turon, J.-L., Eynaud, F., Shackleton, N.J. \& Cayre, O. 2000. Direct land/sea correlation of the Eemian, and its comparison with the Holocene: a high - resolution palynological record of the Iberian margin. Geologie en Mijnbouw, 79, 345-354.

Sesé, C. 2005. Aportación de los micromamíferos al conocimiento paleoambiental del Pleistoceno Superior en la Región Cantábrica: Nuevos datos y síntesis. Museo y Centro de Investigación de Altamira Monografías, 20, 167-200.

Sesé, C. \& Sevilla, P. 1996. Los Micromamíferos del Cuaternario peninsular español: cronoestratigrafía e implicaciones bioestratigráficas. Revista Española de Paleontología, $n^{\circ}$ extraordinario, 278-287.

Sesé Benito, C. \& Soto Rodríguez, E. 1988. Los Micromamíferos (Rodentia, Insectivora y Lagomorpha) de la Cueva de Ambrosio (Almeria, Spain). In: La Cueva de Ambrosio (Almeria, España) y su posición cronoestratigráfica en el Mediterráneo Occidental (Ed. S. Ripoll López). BAR International Series, 462, 157-168.

Sevilla García, P. 1988. Estudio paleontológico de los Quirópteros del Cuaternario español. Paleontologia i Evolució, 22, 113-233.

Straus, L.G. 2005. A mosaic of change: the Middle-Upper Paleolithic transition as viewed from New Mexico and Iberia. Quaternary International, 37, 47-67.

Straus, L.G. \& González Morales, M. 2001a. El Mirón Cave 2001: Continuing Excavations by the Universities of Cantabria and New Mexico. Old World Archaeology Newsletter, 23 (2), 1-5.

Straus, L.G. \& González Morales, M. 2001b. The upper paleolithic in El Mirón Cave (Ramales, Cantabria, Spain). Le Paléolithique supérieur européen. Bilan quinquennal 2001-2006, Commission VIII. XVe Congrès UISPP, ERAUL, 97, 135-139.

Straus, L.G. \& González Morales, M. 2003. El Mirón Cave and the C14 Chronology of Cantabrian Spain. Radiocarbon, 45, 41-58.

Straus, L.G. \& González Morales, M. 2007. Further Radiocarbon dates for the Upper Paleolithic of El Mirón Cave (Ramales de la Victoria, Cantabria, Spain). Radiocarbon, 49, 1205-1214.

Straus, L.G., González Morales, M., Farrand, W.R. \& Hubbard, W.J. 2001. Sedimentological and Stratigraphic Observations in El Mirón, a Late Quaternary Cave Site in the Cantabrian Cordillera, Northern Spain. Geoarchaeology: An International Journal, 16, 603-630.

Straus, L.G., González Morales, M. \& Fano Martínez, M. A. 2006. The Upper Paleolithic record in the Asón River Basin, Eastern Cantabria (Spain. Research \& Publications, 2000-2005). Le Paléolithique supérieur européen. Bilan quinquennal 2001-2006, Commission VIII. XVe Congrès UISPP, ERAUL 115, 117-128.

Sutcliffe, A.J. \& Kowalski, K. 1976. Pleistocene Rodents of the British Isles. Bulletin of the British Museum (Natural History), Geology, 27, 1-147.

Tesakov, A. 1996. Evolution of bank voles (Clethrionomys, Arvicolinae) in the late Pliocene and early Pleistocene 
of Eastern Europe. Acta Zoologica Cracoviensia, 39, 541-547.

Uriarte Cantolla, A. 2003. Historia del Clima de la Tierra. Servicio Central de Publicaciones del Gobierno Vasco, Vitoria-Gasteiz, 1-306.

Vargas, J.M. \& Palomo, L.J. 1990. Selección de la lechuza común (Tyto alba) sobre el topillo común (Microtus duodecimcostatus). Doñana, Acta Vertebrata, 17, 223-229.

Ventura, J. \& Sans-Fuentes, M.A. 1997. Geographic variation and divergence in nonmetric cranial traits of Arvicola (Mammalia, Rodentia) in southwestern Europe. Zeitschrift für Säugetierkunde, 62, 99-107.

Ventura, J., López-Fuster, M.J. \& Gosàlbez, J. 1993. A morphometric analysis of cranial variation in the bank vole, Clethrionomys glareolus (Schreber, 1780) (Rodentia, Arvicolidae) from the Iberian Peninsula. Zoologischer Anzeiger, 231, 183-193.

Villalta, J. F. 1972. Presencia de la Marmota y otros elemen- tos de la fauna esteparia en el Pleistoceno catalán. Acta Geológica Hispánica, 7, 170-173.

Wilson, D.E. \& Reeder, D. M. (eds.) 2005. Mammal Species of the World. A Taxonomic and Geographic Reference. Johns Hopkins University Press, Third Ed., Baltimore, Maryland, 2, 1-142.

Zabala, J. 1983. Primera cita de Arvicola sapidus (Miller 1908, Mammalia, Rodentia) para la provincia de Guipúzcoa. Munibe, 35, 109-114.

Zubeldia Garmendia, H. 2006. Goi Pleistozenoko-Behe Holozenoko Antoliñako Koba aztarnategiaren mikroornodunen ikerketa (Arteaga, Bizkaia). Arkeztutako Tesis de Licenciatura, Universidad del País Vasco, Leioa, 1-130 (inédita).
Manuscrito recibido: 8 de Mayo, 2007 Manuscrito aceptado: 4 de Marzo, 2008 


\section{REVISTA ESPAÑOLA DE PALEONTOLOGÍA}

\section{NÚMERO EXTRAORDINARIO X}

(XIX Jornadas de Paleontología, Morella, 16-18 de octubre de 2003)

J. V. SANTAFÉ LLOPIS. Presentación

J. L. SANZ. Aproximación histórica al género Iguanodon. [Historical approach at genus Iguanodon.].

X. PEREDA SUBERBIOLA \& J.I. RUIZ-OMEÑACA. Los primeros descubrimientos de dinosaurios en España. [The first dinosaur discoveries in Spain.]

J.M. GASULLA ASENSIO. Los dinosaurios de Morella (Castellón, España): historia de su investigacion. [The dinosaurs of Morella (Castellón, Spain): History of their investigation.]

O. FERRER \& J. M. DE GIBERT. Presencia de Teredolites en la Formación Arcillas de Morella (Cretácico Inferior, Castellón). [Presence of Teredolites in the Morella Mudstone Formation (Lower Cretaceous, Castellón).]

A.M. BRAVO, B. VILA, A. GALOBART \& O. OMS. Restos de huevos de dinosaurio en el Cretácico Superior del sinclina de Vallcebre (Berguedà, provincia de Barcelona). [Dinosaur egg remains from the Upper Cretaceous of Vallcebre Syncline (Berguedà, Barcelona Province).]

J.L. BARCO, J. I. CANUDO, J. I. RUIZ-OMEÑACA \& J.L. RUBIO. Evidencia icnológica de un dinosaurio terópodo gigante en el Berriasiense (Cretácico Inferior) de Laurasia (Las Villasecas, Soria, España). [Ichnological evidence of a giant theropod dinosaur in Berriasian (Lower Cretaceous) of Laurasia (Las Villasecas, Soria, Spain).].

F. TORCIDA FERNÁNDEZ-BALDOR, J.I. RUIZ-OMEÑACA, L.A. IZQUIERDO MONTERO, D. MONTERO HUERTA, G. PÉREZ MARTÍNEZ, P. HUERTA HURTADO \& V. URIÉN MONTERO. Dientes de un enigmático dinosaurio ornitópodos en el Cretácico Inferior de Burgos (España). [Enigmatic ornithopod teeth from the Lower Cretaceous of Burgos (Spain).]

C. FUENTES VIDARTE, M. MEIJIDE CALVO, F. MEIJIDE FUENTES \& M. MEIJIDE FUENTES. Fauna de vertebrados del Cretácico Inferior del Yacimiento de "Zorralbo" en Golmayo (Soria, España). [Vertebrate fauna (Lower Cretaceous) of the site "Zorralbo" a Golmayo (Soria, Spain).]

M. SUÑER, C. DE SANTISTEBAN \& A. GALOBART. Nuevos restos de Theropoda del Jurásico Superior - Cretácico Inferior de la Comarca de los Serranos (Valencia). [ New Upper Jurassic - Lower Cretaceous Theropoda remains from 'Los Serranos' region (Valencia).]

F.J. RUIZ-SÁNCHEZ, C. DE SANTISTEBAN \& J.I. LACOMBA. Cazuma 1, nueva localidad de micromamíferos (Mammalia, Rodentia) del Aragoniense Superior en la cuenca de Quesa - Bicrop (prov. Valencia). [Cazuma 1, new micromammal locality (Mammalia, Rodentia) of Late Aragonian of the Quesa - Bicorp basin (Valencia, Spain).].

M.A. SALINAS JAQUES. Las hipótesis de Eduardo Boscá sobre la alimentación del megaterio y el montaje del ejemplar de la Colección Rodrigo Botet (1902-1928). [The Eduardo Bosca's hypothesis about the megatherium's feeding and the assembly of the Rodrigo Botet Collection's specimen (1902-1928).].

F.J. RUIZ-SÁNCHEZ. La legislación de medio ambiente y la protección del patrimonio paleontológico en la Comunidad Valenciana (España). [The environmental legislation and paleontological heritage protection in the Valencian Community (Spain).] 
Apellidos

Last name

Título/Title

(dirección/address)

C.P.

Zip Code

Ciudad

City/State
País

Country

(temas; edades; área geográfica / fields; ages; geographic area

Solicita ser admitido en la Sociedad Española de Paleontología como:

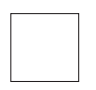

Socio ordinario
Ordinary membership

Socio estudiante (menores de 27 años)

Student membership (under 27 years old)

Cuota 2008
2008 Dues $\{50$ euros

Cuota 2008
2008 Dues $\left\{\begin{array}{l}20 \text { euros } \\ \text {. }\end{array}\right.$

Fecha de nacimiento

Birth date

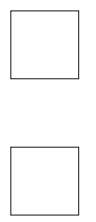

Socio corporativo

Cuota 2008

Institutional membership

2008 Dues

Nombre

First name

Tlfno: :

\section{(nombre del Centro / Institution name)}

Presentado por/Presented by

(dos socios/two members)

Certificación de la condición de estudiante (sólo para socios estudiantes)

Certification of student status (for student members only)

Certifico que el solicitante es

estudiante/doctorando en el

Dpto. de

de la

(institución)
I certify that the above-named is a full-time undergraduate/postgraduate student in the

Dept. of

at

Fecha y firma/Date and signature

(nombre y título / full name and title)

Enviar una copia a: Send a copy to:
Secretaría de la Sociedad Española de Paleontología

Museo Nacional de Ciencias Naturales

C/. José Gutiérrez Abascal, 2

E-28006 MADRID

ESPAÑA/SPAIN 